\title{
NAAR NIEUWE WEGEN IN HET MILIEUBELEID
}


De Wetenschappelijke Raad voor het Regeringsbeleid werd in voorlopige vorm ingesteld in 1972. Bij wet van 30 juni 1976 (Stb. 413) is de positie van de raad definitief geregeld. De huidige zittingsperiode loopt tot 31 december 2002.

Ingevolge de wet heeft de raad tot taak ten behoeve van het regeringsbeleid wetenschappelijke informatie te verschaffen over ontwikkelingen die op langere termijn de samenleving kunnen beïnvloeden. De raad wordt geacht daarbij tijdig te wijzen op tegenstrijdigheden en te verwachten knelpunten en zich te richten op het formuleren van probleemstellingen ten aanzien van de grote beleidsvraagstukken, alsmede op het aangeven van beleidsalternatieven.

Volgens de wet stelt de WRR zijn eigen werkprogramma vast, na overleg met de minister-president die hiertoe de Raad van Ministers hoort.

De samenstelling van de raad is (tot 31 december 2002):

prof.mr. M. Scheltema (voorzitter)

prof.dr.ir. J. Bouma

prof.dr. F.A.G. den Butter

prof.dr. M.C.E. van Dam-Mieras

prof.dr. G.A. van der Knaap

prof.dr. P.L. Meurs

prof.dr. J.L.M. Pelkmans

prof.dr.mr. C.J.M. Schuyt

Secretaris: prof.dr. J. van Sinderen

De WRR is gevestigd:

Plein 1813, nr. 2-4

Postbus 20004

2500 EA 's-Gravenhage

Telefoon 070-35646 oo

Telefax 070-356 4685

E-mail info@wrr.nl

Website http://www.wrr.nl 


\section{WRR}

WETENSCHAPPELIJKE RAAD VOOR HET REGERINGSBELEID

\section{NAAR NIEUWE WEGEN IN HET MILIEUBELEID}


ISBN 90-12-09936-6 


\section{WRR}

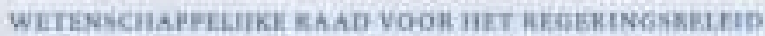

Aan de Minister-president

Minister van Algemene Zaken

De heer mr. dr. J.P. Balkenende

Postbus 20001

2500 EA Den Haag

ons kenmerk

$2007 i 60 / m a n$.

Onderwerp

Rapoart nr. 67 doorklesnummer

$070-355-4662$

email

schelternagwrt. $\mathrm{h}$ teiefax

$070-3564685$

datum

7 mei 2003

Herbif zenden wij $U$ het rapport toe 'Naar nieave wegen in het milieubeleid.

Het rapport betret de gewenste beleidsvorming woor de nu nog openstaande, hardnekbige milieuproblemen zoals de problematiek van de CO2. uitstnot en van kfimaatverandering en de afnemende biodiversteit, en de relatief nieuwe milieuprobiemen die zich de komende jaren zullen manifesteren.

Deze problemen, die nog niet binnen de bestaande beleidskaders beheersbear zijn gemaaks, hebben gemeenschappeljke kenmerken. Er is sprake van een bovennationale schaal en van een lange tijdsdimensie. De nadelige effecten manifesteren zich minder direct en duidelijk. Din betekent dat een zwaar beroep op de wetenschap moet worden gedaan, zowed voor de onderkenning van de probiemen als voor het rocken naar een cplassing. Het gegeven dat de wetenschap by dit type complexe milieuprobiemen vask niet de gewenste zekerfieid kan bieden, maakt de overheidstaak extra moeligk. Hetzelfde geidt voor do betrokkenheid van meerdere overheidsniveaus bij de beleidsvoering.

voor deze problemen kan niet worden uitgegaan van de bestasnde, vertrouwde beleidsconcepten, De legitimatie van het overheidsbeleid vraagt on nieuwe combinaties van mobilisatie van kennís en een brede mastschappelijke deling en inbedding van die kennis. Alleen dar kan het idee ván maatschappeijike urgentie ortstaan dat nodig is om de milieueffecten op langere termijn een adequate plaats te geven in de afweging met andere belangen.

Deve bevinding werkt de raad uit ap een vertal puntens het omgaan met wetenschappelijke kernis en onzeloerheid, de organisatie van de maatschappeljke inbedding van kennis, de intermedaire scharnierfunctie van de nationale overheid tussen de verschillonde territoriaie niveaus, en de gevvenste verdeling van milieutaken tussen met name de Europese en de nationale overheid.

Het rapport is inhoudelijk nog in de zesde raadsperiode tot stand gekomen. Volgens de procedure van de Instelingswet ziet de raad graag de bevindingen van de ministerraad tegemoet.

De vocraitter

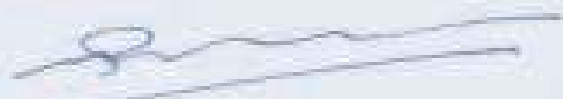

prof. my. M. Scheltenia
De sectetaris

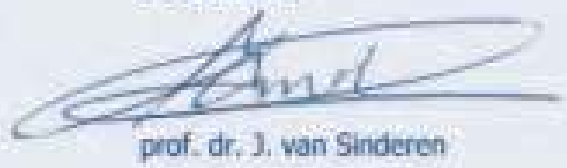




\section{INHOUDSOPGAVE}

\section{Samenvatting}

Ten geleide

$1 \quad$ Inleiding 19

1.1 Probleemstelling: nieuwe uitdagingen aan het milieubeleid 19

1.2 Context: mondiale problemen, causale onzekerheid, opschaling bestuur 20

$\begin{array}{ll}1.3 & \text { Opbouw van het rapport }\end{array}$

$2 \quad$ Milieuproblemen, milieubeleid en kennisimplicaties 27

$\begin{array}{ll}2.1 & \text { Inleiding }\end{array}$

$\begin{array}{lll}2.2 & \text { De periode } 1970-1988 & 27\end{array}$

$\begin{array}{ll}\text { 2.2.1 Algemeen } & 27\end{array}$

$\begin{array}{lll}2.2 .2 & \text { De aard van de problemen } & 28\end{array}$

2.2.3 Ontwikkelingen in het beleid $\quad 29$

2.2.4 Kennisaspecten 30

2.2.5 Conclusies 31

$2.3 \quad$ De periode $1988-1998 \quad 31$

2.3.1 Algemeen 31

2.3.2 De aard van de problemen $\quad 32$

2.3.3 Ontwikkelingen in het nationale beleid 33

$\begin{array}{ll}2.3 .4 & 35 \\ 2.3 .5 & \end{array}$

$\begin{array}{ll}2.3 .5 & \text { Ontwikkelingen op Europees niveau }\end{array}$

$\begin{array}{lll}2.3 .6 & \text { Conclusies } & 38\end{array}$

$\begin{array}{lll}2.4 & \text { De periode vanaf } 1998 & 39\end{array}$

2.4.1 De aard van de milieuproblemen $\quad 39$

2.4.2 Ontwikkelingen in het nationale beleid 40

2.4.3 Kennisaspecten 41

2.4.4 Ontwikkelingen op Europees niveau 41

2.4.5 Conclusies 42

$\begin{array}{lll}2.5 & \text { Toekomstperspectief } & 43\end{array}$

2.5.1 Internationale beleidsperspectieven $\quad 45$

2.5.2 Beleidsperspectieven op nationaal niveau 46

$\begin{array}{lll}2.5 .3 \quad C o n c l u s i e s & 50\end{array}$

2.6 Algemene conclusies: vragen en aandachtspunten voor de toekomst $\quad 5^{1}$

2.6.1 De aard van de problemen 51

2.6.2 Beleid en bestuur 53

2.6.3 Kennisaspecten 
$3 \quad$ Voorwaarden voor een goed milieubeleid 63

$3.1 \quad$ Inleiding 63

3.2 Criteria voor de vorming van beleid 66

3.2.1 Legitimatiebronnen en handelslogica van beleid 66

$\begin{array}{ll}\text { 3.2.2 Rechtmatigheid } & 69\end{array}$

3.2.3 Doeltreffendheid en doelmatigheid 71

$\begin{array}{ll}\text { 3.2.4 Haalbaarheid } & 71\end{array}$

$\begin{array}{ll}\text { 3.2.5 Aanvaardbaarheid } & 72\end{array}$

3.3 Spanningen tussen de criteria bij milieubeleid 73

3.4 De rol van kennis en participatie in de beleidsvorming 78

3.4.1 De vorming van draagvlak voor beleid als cyclisch proces $\quad 78$

$\begin{array}{ll}\text { 3.4.2 Het belang van kennis en informatie } & 81\end{array}$

3.4.3 Het belang van participatie en interactie $\quad 83$

3.4.4 Dilemma's rond arrangementen van milieubeleid $\quad 85$

\begin{tabular}{ll}
3.5 & Naar een empirische analyse \\
\hline 7
\end{tabular}

$4 \quad$ Praktijken van beleidsvorming $\quad 89$

$\begin{array}{llr}4.1 & \text { Inleiding } & 89\end{array}$

4.2 Hinderproblemen: Rijnmond en Schiphol 91

$\begin{array}{lll}4.2 .1 \quad \text { Inleiding } & 91\end{array}$

4.2.2 Luchtverontreiniging in Rijnmond 92

$\begin{array}{ll}\text { 4.2.3 Schiphol } & 96\end{array}$

4.3 Richtlijnen uit Brussel: de Vogelrichtlijn en de Nitraatrichtlijn 103

$\begin{array}{lll}4.3 .1 & \text { Inleiding } & 103\end{array}$

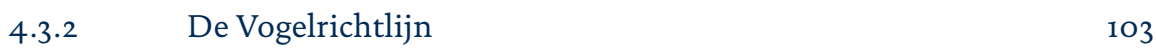

$\begin{array}{ll}\text { 4.3.3 De Nitraatrichtlijn } & 106\end{array}$

4.4 Onzeker en onzichtbaar: klimaatverandering en

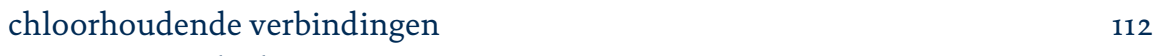

$\begin{array}{ll}4.4 .1 & 112\end{array}$

$\begin{array}{ll}4.4 .2 & 112\end{array}$

4.4.3 Chloorhoudende verbindingen 118

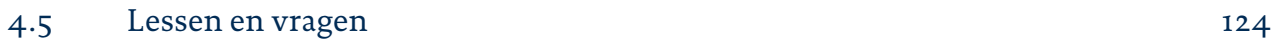

$\begin{array}{ll}\text { 4.5.1 Moeizame beleidsvorming } & 124\end{array}$

$\begin{array}{ll}\text { 4.5.2 Voortgang in de beleidsvorming } & 125\end{array}$

$\begin{array}{lll}4.6 & \text { Conclusie } & 127\end{array}$

5 Perspectief 129

$\begin{array}{lll}5.1 & \text { Inleiding } & 129\end{array}$

5.1.1 Van oude naar nieuwe milieuproblemen $\quad 129$

5.1.2 Opbouw van het hoofdstuk 130

5.2 De rol van kennis en onzekerheid $\quad 131$

5.2.1 De rol van kennis voor de nieuwe milieuproblemen $\quad 132$

5.2.2 Onzekerheid in soorten en maten 133

$\begin{array}{ll}\text { 5.2.3 Risicoanalyse en voorzorgsbeginsel } & 135\end{array}$ 
5.2.4 De organisatie van de kennisinbreng in het beleid

5.2.5 Arrangementen voor vermaatschappelijking van kennis 141

5.3 Participatie door maatschappelijke groeperingen

5.4 Internationaal milieubeleid en de scharnierfunctie van de nationale overheid 148

5.4.1 Schaalvergroting

148

5.4.2 Internationale samenwerking op wereldschaal

151

$5 \cdot 4 \cdot 3$

Ontwikkelingen in het milieubeleid van de EU

152

$5.5 \quad$ Conclusies

155

Literatuur 163 


\section{SAMENVATTING}

\section{Onderwerp van het rapport}

In het milieubeleid is een nieuwe generatie problemen opgekomen die nog niet binnen de bestaande beleidskaders beheersbaar is gemaakt. Het gaat ten eerste om enkele hardnekkige, voortslepende problemen zoals $\mathrm{CO}_{2}$-uitstoot, klimaatverandering en afnemende biodiversiteit. Ten tweede gaat het om een reeks relatief nieuwe, opkomende problemen zoals de effecten van gevaarlijke stoffen, de milieu-implicaties van de moderne biotechnologie, de aanhoudende volumegroei in het gebruik van energie en mobiliteit, en nieuwe vormen van biologische verontreiniging. ${ }^{1}$ Voor deze nieuwe generatie wicked milieuproblemen geldt dat zij een bovennationale schaal en een lange tijdsdimensie hebben. Het gaat om sluipende ontwikkelingen. Bovendien manifesteren de effecten zich minder direct en duidelijk dan bij de 'oudere', inmiddels wel beheersbaar gemaakte milieuproblemen, waarbij sprake is van zintuiglijk waarneembare hinder, zoals stankoverlast of geluidshinder.

Dit rapport gaat over de vraag hoe een beleid tot stand dient te komen met betrekking tot deze gecompliceerde, nog ongetemde milieuproblemen. De problemen moeten in zekere zin worden 'bedacht'. Ze moeten worden geconceptualiseerd in de hoofden van mensen zonder dat zij er ervaringsverhalen bij hebben. Overheden staan voor de taak om maatregelen te nemen voordat zich ernstige effecten manifesteren.

Het gegeven dat de wetenschap bij dit type complexe milieuproblemen niet altijd de gewenste zekerheid kan bieden, maakt de overheidstaak extra moeilijk. De burgers zullen de milieuproblematiek moeilijk kunnen begrijpen en aanvaarden. De overheid zal problemen ervaren bij het verwerven van draagvlak voor de ingrijpende beleidsmaatregelen. Het is bovendien lastig het milieubeleid te legitimeren, omdat de ernstige effecten van de problemen:

- in de toekomst liggen;

- zich deels vooral direct zullen manifesteren op ver weg gelegen plekken op de aarde en derhalve om internationale verbondenheid vragen;

- zich wellicht helemaal niet zullen voordoen.

Twee aanvullende aspecten versterken de moeilijkheidsgraad van de beleidsvorming nog meer. Ten eerste zijn er meerdere overheidsniveaus bij de beleidsbepaling betrokken. Op internationaal niveau wordt het beleid in hoofdlijnen vastgesteld (wat Nederland betreft in het bijzonder door de eu), maar overheden op nationaal en lager niveau blijven wel een duidelijke rol spelen. Ten tweede is de verhouding tussen overheid en samenleving geen constante, maar is zij aan fluctuatie onderhevig. Dat werkt door in de (opvatting over de) verdeling van verantwoordelijkheden tussen overheden en andere maatschappelijke actoren, ook op milieuterrein. 


\section{Aanleiding en focus van het rapport}

Gezien de aard van de nog niet beheersbaar gemaakte problemen en gezien de veranderende bestuurlijke en maatschappelijke context kan de overheid in haar toekomstige beleidsvorming niet zonder meer uitgaan van de vertrouwde beleidsconcepten. De raad heeft in zijn vorig jaar uitgebrachte rapport Duurzame ontwikkeling. Bestuurlijke voorwaarden voor een mobiliserend beleid (WRR 2002b) een aantal bestuurlijke elementen benoemd:

- versterking van de samenwerking tussen overheid en andere actoren, op basis van gedeelde én te onderscheiden verantwoordelijkheden;

- een meer samenhangend beleid op nationaal niveau;

- nieuwe (concrete en gerichte) vormen van internationale samenwerking.

Het onderhavige rapport bouwt hierop voort. Het richt zich op de vraag hoe wetenschappelijke kennis en maatschappelijke participatie kunnen bijdragen aan een breder draagvlak voor beleidsmaatregelen voor de hardnekkige en nieuwe milieuproblemen. De aard van die problemen brengt met zich mee dat een zwaar beroep op de wetenschap wordt gedaan, een beroep dat de wetenschap maar ten dele kan honoreren. De territoriale schaal en de lange tijdsdimensie van de problematiek bemoeilijken de directe betrokkenheid en participatie van burgers. De problemen liggen 'ver van hun bed'. De internationalisering van de besluitvorming is in dit verband evenzeer een complicerende factor. Derhalve is een sociale inbedding van (wetenschappelijke) kennis nodig, opdat betrouwbare kennis ook maatschappelijk gedeelde, relevante kennis kan worden. Tegen deze achtergrond tracht dit rapport handreikingen en zoekrichtingen te bieden. Deze komen met name aan de orde in het slothoofdstuk.

\section{Analyse}

$\mathrm{Na}$ een historische verkenning in hoofdstuk 2 biedt hoofdstuk 3 het beleidsanalytische kader. Eerst komen vier algemeen geldende criteria voor goed beleid aan de orde: rechtmatigheid, doelmatigheid en doeltreffendheid, politieke haalbaarheid en maatschappelijke aanvaardbaarheid. Een nadere analyse gaat in op de spanningen en dilemma's die deze criteria vooral in hun onderlinge verband oproepen.

De internationalisering van het beleid en de meerdere overheidslagen, leidend tot beleid op verschillende bestuurlijke schalen, versterken deze spanningen. Vervolgens analyseert het hoofdstuk de wijze waarop kennis en participatie kunnen worden aangewend om de legitimiteit van het beleid te waarborgen. Tal van beleidsarrangementen staan de overheid daartoe ter beschikking. De analyse maakt duidelijk dat deze arrangementen vragen om een actieve, ondernemende overheid die zichzelf de opdracht stelt draagvlak te verwerven.

Hoofdstuk 4 analyseert een zestal specifieke milieucasussen. Het hoofdstuk is mede gebaseerd op het WRR-Werkdocument Milieubeleid in een veranderende context: zes voorbeelden, waarin de casussen empirisch worden onderbouwd. Er komen eerst twee milieuthema's aan bod die binnen de bestaande beleidskaders inmiddels beheersbaar zijn gemaakt: luchtverontreiniging in Rijnmond en 
geluidshinder rond Schiphol. Daarna volgen vier nog niet beheersbaar gemaakte problemen: de Europese Vogelrichtlijn, de Europese Nitraatrichtlijn, klimaatverandering en chloorhoudende verbindingen. De eerste twee casussen betreffen in hoge mate nationaal beleid, bij de twee volgende casussen ligt het zwaartepunt van de besluitvorming op Europees niveau, terwijl bij klimaatverandering en chloor het overige internationale beleid sterk intervenieert. Bij deze laatste categorie spelen bovendien het gebrek aan relevante kennis en de grote mate van onzekerheid het sterkst. In alle casussen staat steeds de vraag voorop hoe in de loop der tijd beleidsarrangementen zijn ontwikkeld waardoor kennis en participatie in meer of mindere mate hebben geleid tot een gelegitimeerd beleid in de termen van de vier hiervoor genoemde criteria.

Het beeld dat uit de zes analyses naar voren komt is dat in alle gevallen de vorming van gelegitimeerd beleid moeizaam verloopt. Toch blijkt het steeds mogelijk daarin voortgang te boeken door een combinatie van kennisvergaring en participatiebevordering. Steeds blijkt uit de verschillende casussen dat arrangementen van vermaatschappelijking van kennis cruciaal zijn. Het gaat daarbij om het toepasbaar en aanvaardbaar maken van wetenschappelijk gevalideerde kennis binnen de termen die worden gehanteerd door de betrokken actoren.

\section{Bevindingen van de raad}

\section{Onzekerheid en kennis}

Een van de kenmerken van persistente milieuproblemen is dat zij met grote onzekerheden zijn omgeven. Voor de beleidsvorming is het van belang vooraf vast te stellen welk type van onzekerheid er bij een specifiek milieuprobleem in het geding is. Is er sprake van redelijkerwijs reduceerbare onzekerheid of van meer structurele onzekerheid die moeilijker is te reduceren? Er zijn twee gangbare benaderingen om in het milieubeleid met onzekerheid om te gaan, te weten risicoanalyse en hantering van het voorzorgsbeginsel. Zij moeten niet zonder meer als tegenstelling worden gezien. Risicoanalyse gebiedt tot een afweging van risico's. Die (gepercipieerde) risico's moeten worden afgewogen in de politieke besluitvorming. Daarbij speelt ook de gewenste mate van risicomijding een rol. Een risicoanalyse kan uitwijzen dat de aanwezige kennis ontoereikend is om (voldoende) zekerheid te verschaffen over een milieukwestie, gegeven de gewenste mate van risicomijding. In die gevallen kan de afweging tussen het bekende en het onbekende nopen tot voorzorg. Daar, aan de 'rand van de kennis', kan de politiek voor voorzichtigheid opteren. Het voorzorgsbeginsel is derhalve eerder een normatief concept dat wordt ingegeven door risicomijding bij grote onzekerheid, dan een wetenschappelijke benadering.

De grote kwetsbaarheid van het voorzorgsbeginsel ligt in het gevaar dat, waar toepassing leidt tot het afzien van mogelijk voor het milieu schadelijk handelen, eventuele alternatieven voor en verdere implicaties van dit afzien al snel buiten beeld blijven. Toepassing van dit beginsel kan bovendien te gemakkelijk en ten onrechte stimulansen tot verder onderzoek wegnemen, en een periodieke herwaardering van de situatie op basis van uitkomsten van dit nieuwe onderzoek 
uitsluiten. Toepassing van het voorzorgsbeginsel is derhalve geen panacee, waarmee de zaak 'eens en voor altijd' kan worden afgedaan.

\section{Participatie}

De organisatie van het proces van beleidsvorming vergt een aparte oriënterende fase, na de agendering van het probleem, maar vóór de daadwerkelijke besluitvorming en uitvoering. Kernpunt van deze fase is het toepasbaar en aanvaardbaar maken van wetenschappelijk gevalideerde, onafhankelijk totstandgekomen kennis binnen de handelingsperspectieven van de maatschappelijke actoren die belang hebben bij de besluitvorming. Dit vergt een actieve, open consultatie onder regie van de overheid. Een responsieve overheid moet bevorderen dat het geheel van relevante kennis, expertise en argumenten ook ter tafel komt en een rol kan spelen in de besluitvorming. De besluitvorming en de feitelijke afweging van waarden en belangen blijven een eigen zaak van de overheid, gegeven haar unieke democratische mandaat voor de vaststelling van het publiek belang.

\section{De bestuurlijke rol van de nationale overheid}

In bestuurlijke zin vraagt de toenemende vervlechting van het beleid op internationaal en lager nationaal niveau om een versterking van de 'scharnierfunctie' van de nationale overheid. Een initiërende rol van de nationale overheid in internationale gremia wekt slechts vertrouwen indien zij ook in de vervolgfase zorgt voor adequate uitvoering van de aangegane internationale verplichtingen. Deze scharnierfunctie vergt een vertaalslag in beide richtingen. Internationale beleidsontwikkelingen moeten worden vertaald naar de Nederlandse context. Het internationale oriënterende beraad moet zijn tegenhanger vinden in een vroegtijdig beraad op nationaal schaal. De uitkomsten van dit nationale beraad moeten vervolgens een rol spelen in de nationale, Nederlandse inbreng op het hogere niveau.

Specifieke aandacht vergt hier het vroegtijdig op elkaar betrekken van beleidsvorming en uitvoering. Voor de bepaling van de Nederlandse inbreng gaat het niet alleen om de vraag of internationale voorstellen aansluiten op geldend Nederlands beleid op het niveau van de doelen. De repercussies van de mogelijke uitvoering van de internationale voorstellen binnen de eigen Nederlandse structuur en cultuur van beleid moeten vooraf worden meegewogen.

\section{Het Europese milieubeleid}

In het recente raadsrapport Slagvaardigheid in de Europabrede Unie (WRR 2003c) heeft de raad gepleit voor een breder scala van bestuursvormen binnen Europa, gelet op de eigenheid van een sector, en voor meer mogelijkheden van variatie binnen de communautaire besluitvormingsmethode. De bevindingen van de raad in het onderhavige rapport liggen in het verlengde van deze aanbeveling. Gegeven de aard van de nu op de beleidsagenda staande milieuproblemen, en met name de internationale schaal waarop zij zich voordoen, heeft (het nalaten van) nationaal beleid ingrijpende externe effecten. In die situatie is het zinnig dat op een hoger, met name Europees niveau doelen en geloofwaardige sanctiemecha- 
nismen worden vastgesteld. Tegelijk zijn er goede redenen om de nationale overheden enigermate vrij te laten in de wijze waarop deze doelen worden bereikt. De spanningen tussen eisen van internationaal beleid en de eigen binnenlandse structuur en cultuur van beleid kunnen dan tot reële proporties worden gereduceerd. Op uitvoeringsniveau kan zo beter gebruik worden gemaakt van de op nationaal en lager niveau aanwezige expertise. Mogelijkheden tot samenspraak tussen overheden en betrokkenen worden op dit uitvoeringsniveau dan niet onnodig ingeperkt. 


\section{NOTEN}

1 Over biotechnologie heeft de raad eveneens aan het eind van de zesde raadsperiode een apart rapport uitgebracht: Beslissen over biotechnologie (WRR 2003a). In het onderhavige rapport wordt dit onderwerp dan ook niet behandeld. 




\section{TEN GELEIDE}

Het rapport is voorbereid door een interne projectgroep van de WRR, die ten tijde van de vaststelling van het rapport, december 2002, als volgt was samengesteld. Voorzitter was prof. dr. ir. J. Bouma, toenmalig lid van de raad. Verder maakten deel uit van de projectgroep: prof. dr. F.A.G. Den Butter, eveneens toenmalig lid van de raad, dr. A.C. Hemerijck, adjunct-secretaris en de (deels toenmalige) stafleden mw. drs. J.Burgers, drs. H.O. Dijstelbloem, dr. C.A. Hazeu, dr. F. den Hond en drs. I.J. Schoonenboom. Het staflid mr. dr. F.J.P.M. Hoefnagel was vanaf 1 juli 2002 projectsecretaris; tot die datum vervulde dr. B. Wissink, destijds lid van de staf, deze functie.

In het kader van dit project zijn twee werkdocumenten van de WRR verschenen. 1.Werkdocument nr. 128 'Perspectieven op milieurisico's', onder redactie van J.Bouma en B. Wissink, WRR Den Haag, april 2002; een drietal deskundigen werd gevraagd een essay te schrijven over dit thema vanuit verschillende disciplines: financiële economie en kansrekening: dr. A.Lucas; wetenschapsfilosofie en -sociologie: prof. dr. A. Rip en dr. W.A Smit; het milieuaansprakelijkheidsrecht: prof. mr. J.M. van Dunné.

2.Werkdocument nr. 134 'Milieubeleid in een veranderende context: zes voorbeelden', onder redactie van J.Burgers, F.J.P.M. Hoefnagel en F. Den Hond, WRR Den Haag juni 2003. Dit document is voor het onderhavige rapport bij uitstek van belang, daar het de nadere empirische en documentaire onderbouwing geeft van de zes casussen die in hoofdstuk vier van dit rapport zijn geanalyseerd. Aan de orde komen: 1. Luchtverontreiniging in Rijnmond (J. Burgers), Schiphol, de moeizame dialoog tussen economie en milieu (F.A.G. den Butter en J.Burgers), EG Vogelrichtlijn 1979 (F.J.P.M. Hoefnagel), Stikstof in de landbouw (J.Bouma), Klimaatverandering ( J.Burgers) en Risico's van chloorhoudende verbindingen (F. den Hond). 


\subsection{PROBLEEMSTELLING: NIEUWE UITDAGINGEN AAN HET} MILIEUBELEID

In de achterliggende decennia zijn de Nederlandse burgers en overheid vertrouwd geraakt met het milieubeleid als erkend en deels succesvol nieuw beleidsterrein van de overheid. In veel gevallen zijn milieuproblemen op de beleidsagenda terechtgekomen doordat burgers (en gaandeweg ook steeds meer hun plaatsbekleders) te maken kregen met situaties van direct waarneembare overlast. Ook nieuwe wetenschappelijke inzichten, soms mede opgekomen naar aanleiding van het ageren van burgers, droegen bij aan het agenderen van milieuproblemen en de vorming van beleid.

Er is sprake van een deels succesvol beleid, want de implementatie en handhaving van het milieubeleid schieten vaak nog tekort (Evaluatiecommissie Wet milieubeheer 2002). In de beleidsvorming wordt - bewust of onbewust - niet goed onder ogen gezien wie er last of nadeel zullen krijgen van een strikte handhaving van (nieuwe) milieubeleidsmaatregelen. Dat werkt bestuurlijk gedogen in een later stadium in de hand, als 'goedmaker' aan de niet-voorbereide geleadeerden. Het geconstateerde handhavingstekort is een aansporing aan de overheid om het milieubeleid serieuzer te nemen. Door zelf het goede voorbeeld te geven in de vorm van een consequente(re) handhaving zal de overheid bovendien burgers en bedrijven (beter) kunnen motiveren en zal zij private partijen ook meer in het beleid kunnen betrekken (Ministerie van VROM 2001a). Publieke en private verantwoordelijkheden zijn geen substituten voor elkaar, maar moeten elkaar versterken en op elkaar kunnen bouwen.

Naast deze reguliere (milieu)beleidsproblematiek is er thans ook sprake van opschaling van problemen en bestuursniveaus. Er is een nieuwe generatie uiterst hardnekkige milieuproblemen die vanwege de mondiale externe effecten een wereldwijd handelen vergen. Het belangrijkste voorbeeld is de $\mathrm{CO}_{2}$-uitstoot, en de opwarming van de aarde die daar het mogelijke gevolg van is. Andere voorbeelden zijn het verlies aan biodiversiteit en de mogelijke negatieve gevolgen van biotechnologische toepassingen. Dergelijke ontwikkelingen onttrekken zich aan de dagelijkse waarneming, geven geen directe overlast, maar doen zich sluipenderwijs voor.

De aard van die problemen brengt met zich mee dat milieubeleid steeds minder exclusief Nederlands beleid is. Het beleid is meer ingebed in een internationale context en is voor een groot deel een rechtstreeks gevolg van EU-beleid. Dat beleid laat zich leiden door het 'economische project' dat aanzet tot gelijkwaardige markt- en productieomstandigheden in de betrokken landen. Met de aanstaande grote uitbreiding van de EU is de vraag nog indringender aan de orde hoe Nederland daarin zijn rol speelt. Kunnen we bijvoorbeeld aantonen dat onze 
'polderachtige' oplossingen - bijvoorbeeld het betrekken van bedrijven en burgers in het beleid in de vorm van convenanten - (via een verhoogd draagvlak) tot betere resultaten leiden? De andere kant van deze medaille is dat we in de nationale beleidsvorming de strekking van EU-richtlijnen ook beter op het netvlies moeten hebben om onaangename verrassingen te voorkomen.

In die context van belangrijker wordende internationale kaders moeten ook 'participatie' en 'kennis' - als de twee mobilisatie- en legitimatiemechanismen voor beleid - worden georganiseerd. Bij de inbreng van kennis gaat het om de bijdrage vanuit verschillende wetenschappelijke disciplines en de doorsijpeling daarvan die moet leiden tot een beter begrip, urgentiegevoel, en mogelijke oplossingen ten aanzien van milieuproblemen. Soms kan ook 'lekenkennis' - de ervaringen van direct betrokkenen - een nuttige rol spelen.

Bij participatie gaat het om de mogelijke manieren waarop direct betrokkenen (stakeholders) kunnen bijdragen aan het beleidsdebat en de beleidsontwikkeling. De vele mogelijkheden tot participatie variëren van vormen van dialoog en interactie, via publieksconsultatie, tot 'marktonderzoek', het meten en vaststellen van preferenties bijvoorbeeld door middel van enquêtes of 'willingness to pay'studies. Daarbij moet ook onder ogen worden gezien dat de rollen en vormen van participatie en kennis niet gegeven en stabiel zijn, en daarom niet zonder meer 'opgeschaald' kunnen worden van het Nederlandse naar het Europese niveau, of van lokale overlast naar mondiale milieuproblemen. Daardoor zijn er deels lessen te leren van eerdere Nederlandse 'oplossingen', maar deels is de aard van de nieuwe problematiek (o.a. gekenmerkt door het ontbreken van direct zintuiglijk waarneembare problemen) en van de relevante bestuurscontext zo wezenlijk anders, dat we ons ook moeten instellen op andere stramienen van beleidsvorming.

Dit advies beoogt een aantal handreikingen te bieden voor de vorming van toekomstig milieubeleid in internationaal perspectief. De analyse en aanbevelingen vinden hun startpunt in de volgende probleemstelling:

Hoe kunnen voorwaarden worden geschapen voor een succesvol beleid ten aanzien van met name de hardnekkige en nieuwe milieuproblemen, gegeven de veranderende context van bestuur en de wijzen van legitimatieverwerving voor beleid?

Paragraaf 1.2 licht de vraagstelling en de veranderende context nader toe. Paragraaf 1.3 zet de opbouw van het rapport uiteen.

\subsection{CONTEXT: MONDIALE PROBLEMEN, CAUSALE ONZEKERHEID, OPSCHALING BESTUUR}

\section{Milieubeleid}

Over een periode van ruim 35 jaar is het milieubeleid in Nederland een 'ingedaald' en deels succesvol beleidsterrein geworden. Milieubeleid heeft een 'brede' 
invulling en betekenis gekregen, in aansluiting op de Wet milieubeheer en het EG-Verdrag (Ministerie van VROM 20o1a: 21-23). De doeleinden van het beleid zijn: bescherming van de gezondheid van de mens; behoud, bescherming en verbetering van de kwaliteit en vitaliteit van ecosystemen, flora en fauna; en een behoedzaam en evenredig gebruik van natuurlijke hulpbronnen. Instrumenten om die doelen te bereiken zijn bijvoorbeeld normstellingen voor milieucompartimenten, beperkingen aan emissies en aan milieubelastende consumptie, en verwijdering van afvalstoffen. Voor vraagstukken ten aanzien van de kwaliteit van lucht en water, industriële emissies, en een groot aantal afvalstoffen zijn er oplossingsstrategieën totstandgekomen. In de Milieubalans 2002 concludeert het Rijksinstituut voor Volksgezondheid en Milieu (RIVM) dat de daling van de milieudruk en de verbetering van de milieukwaliteit op een aantal terreinen tot een afname van de gezondheidsrisico's hebben geleid (RIVM 2002b). Er is bij de ontwikkeling van die oplossingsstrategieën gebruikgemaakt van specifiek ontwikkelde kennis, en op verschillende manieren hebben belanghebbenden aan de analyse en oplossing van de vraagstukken bijgedragen. Deze vraagstukken zijn daarmee beheersbaar gebleven binnen de bestaande beleidskaders.

Niettemin is er alle aanleiding om aandacht te vragen voor het milieubeleid. Enerzijds moet het beeld van de beheersbare problemen worden genuanceerd; anderzijds zijn er grote problemen die binnen de bestaande kaders niet of nog niet beheersbaar zijn. Dit rapport richt zich met name op de beleidsvorming ten aanzien van de (nog) niet beheersbare problemen.

\section{Uitvoerings- en handhavingsproblemen bij het bestaande beleid}

Ten aanzien van de beheersbare problemen zijn twee nuanceringen op zijn plaats. Ten eerste rijzen er vragen over de verhouding van het Nederlandse tot het Europese milieurecht en milieubeleid. Zo wijst het Natuurplanbureau op de gebrekkige implementatie van Europees natuurbeleid, met name van de Vogel- en de Habitatrichtlijn, ondanks de formele inbedding van de desbetreffende richtlijnen in Nederlandse wetgeving (Van der Zouwen en Van Tatenhove 2002). Meer in algemene zin is er momenteel geen overzicht van hoe het gesteld is met de formele juridische implementatie van Europese wetgeving in Nederland (hoewel daar hard aan wordt gewerkt; zie www.eu-milieubeleid.nl). Ten tweede is er de vraag in hoeverre de bestaande normen en kaders ook daadwerkelijk worden geïmplementeerd en gehandhaafd. De Evaluatiecommissie Wet milieubeheer (2002) heeft hier recent enkele noten over gekraakt. Zij constateert bijvoorbeeld dat tien tot vijftien procent van de vergunningplichtige inrichtingen zonder (toereikende) vergunning werkt en dat er grote verschillen zijn in de frequentie en wijze van controleren (vooraf aankondigen, al dan geen hercontrole, al dan niet opleggen van sancties).

De zorg voor de natuur en het milieu is in het internationale recht en de Grondwet als verantwoordelijkheid van de nationale overheid vastgelegd, vergelijkbaar met beleidsterreinen als onderwijs en volksgezondheid. Dus niet alleen gerede- 
neerd vanuit de substantie van de problematiek zelf, maar ook vanuit deze (hoge) juridische codificatie is de overheid gehouden tot een serieus milieubeleid. Dat vergt een permanente beleidsinspanning in termen van handhaving en monitoring, zeker in het licht van de waarschijnlijke oorzaken voor het 'handhavingsdeficit': een beperkte handhavingscapaciteit (menskracht en kennis), een gebrekkige informatievoorziening en onvoldoende samenwerking tussen de verschillende bestuurslagen (Van de Peppel 2002).

\section{De nieuwe generatie milieuvraagstukken}

Dit rapport bespreekt de beleidsvorming ten aanzien van 'toekomstige' milieuvraagstukken, dat wil zeggen problemen die zich pas in de toekomst in volle omvang (kunnen) manifesteren en waarvan de aanpak op dit moment nog in de beginfase verkeert. Het betreft milieuvraagstukken die (nog) niet binnen de bestaande beleidskaders beheersbaar zijn en waarbij nog geen zicht op oplossing is. Een belangrijke vraag is of de bestaande kaders het mogelijk maken deze vraagstukken beheersbaar te maken of dat andere vormen van beleidsvoorbereiding nodig zijn. De vraagstukken kenmerken zich door hun mondiale karakter en ontoereikende wetenschappelijke zekerheid over causaliteiten. In de komende decennia zullen zij de beleidsagenda gaan bepalen.

Enerzijds betreft het de nieuwe opkomende problemen, zoals effecten van gevaarlijke stoffen, de milieu-implicaties van de moderne biotechnologie en de voortgaande volumegroei van energiegebruik en mobiliteit. De wetenschappelijke kennis ten aanzien van oorzaken en mogelijke gevolgen is hier nog gebrekkig. Dat belemmert de formulering van doeltreffende oplossingsstrategieën. Een apart advies van de raad is wat dat betreft ingegaan op de kansen en bedreigingen van de moderne biotechnologie (WRR 2003a). Anderzijds gaat het om de openstaande, hardnekkige problemen, zoals het broeikaseffect en de afnemende biodiversiteit, waarbij weliswaar betrekkelijke duidelijkheid is over effecten, maar waarbij maatregelen moeilijk totstandkomen, onder meer vanwege hun ingrijpende karakter. Bij het vraagstuk van klimaatverandering kunnen bijvoorbeeld vragen worden gesteld over de mate van doeltreffendheid van wat klaarblijkelijk politiek en maatschappelijk gezien aanvaardbare maatregelen zijn.

Deze vraagstukken zijn op zich al lastig, maar twee aanvullende aspecten bemoeilijken een effectieve tegemoettreding van deze problemen nog verder. Er is in toenemende mate sprake van de verplichting om EU-wetgeving in de lidstaten te implementeren. Deze bestuurlijke schaalvergroting is enerzijds een voorwaarde om de genoemde problemen het hoofd te bieden. Anderzijds wordt hierdoor de bewegingsruimte van nationale overheden beperkt en kan de beproefde Nederlandse beleidsstijl onder druk komen te staan. Daarnaast zijn opvattingen over staat en samenleving in het algemeen, en over beleidssturing in het bijzonder, aan voortdurende fluctuatie onderhevig.

De overheid wordt dus niet alleen geconfronteerd met nieuwe, grootschalige, ernstige en met onzekerheden omgeven problemen, maar kan bij de aanpak ervan 
zeker niet zonder meer uitgaan van de vertrouwde beleidsconcepten uit het verleden. In het licht van deze ontwikkelingen zou het minder dan ooit gerechtvaardigd zijn om de nieuwe generatie milieuproblemen te bagatelliseren. Gezien hun hiervoor omschreven karakter valt niet zonder meer te verwachten dat deze vraagstukken bij voortzetting van het huidige beleid met een zelfde mate van succes beheersbaar kunnen worden gemaakt. De uitdaging is om te komen tot effectieve maatregelen in een veranderende bestuurlijke context.

\section{Kennis en participatie als legitimatiemechanismen voor beleid}

Twee centrale begrippen in dit rapport zijn kennis en participatie. Kennis en participatie, zoals eerder omschreven, zijn beide nodig om de beleidsbepaling te ondersteunen en de beleidsimplementatie te vergemakkelijken. Idealiter versterken kennis en participatie elkaar (Jasanoff 1990). Er is een zekere sociale inbedding van de bijdrage van wetenschap nodig opdat betrouwbare kennis ook gedeelde, sociaal relevante kennis kan worden. Er is systematische analyse en gericht onderzoek nodig om veronderstellingen te kunnen funderen of weerleggen. De uitdaging is dus om een manier te vinden de verschillende 'stakes' met elkaar in verband te brengen, opdat de (consequenties van) verschillende keuzes tussen ecologische, economische en sociaal-culturele aspecten expliciet kunnen worden gemaakt (WRR 20O2b).

Daarbij komt ook de vraag aan de orde welke positie de Nederlandse overheid inneemt. Zij vervult enerzijds de traditionele rol als besluitnemer ('gehoord alle belangen' en door het parlement gecontroleerd). Anderzijds moet de overheid die publieke taak vervullen in een diffuus krachtenveld waarbij zij ook 'schakelt', zowel verticaal tussen supra- en subnationale overheden, als horizontaal tussen verschillende belangengroepen en partijen; de scharnierfunctie van de nationale overheid.

Een aantal overwegingen is daarbij relevant. De meeste burgers van ons land zien het milieu als een collectief probleem, waarvoor de overheid de leiding moet nemen in het aandragen van oplossingen (RIVM 2002b). Tegelijkertijd moet worden geconstateerd dat al te dirigistisch optreden van de overheid steeds minder wordt geaccepteerd. De huidige pleidooien voor interactiviteit en responsiviteit zijn niet alleen ingegeven door de inherente beperkingen aan het handelingsvermogen van de overheid. Zij zijn ook het resultaat van ontwikkelingen in de richting van centralisatie (de toenemende invloed van de EU), en ook van decentralisatie, privatisering en deregulering in de context van een samenleving waarvan de leden (burgers, bedrijven, belangenbehartigers) eerder dan voorheen geneigd zijn van zich te laten horen. Burgers in de moderne samenleving verlangen de garantie van immuniteit ten aanzien van de risico's van vooruitgang en technologische ontwikkeling (Beck 1992). Maar tegelijkertijd zijn burgers niet erg geneigd te accepteren dat de overheid, wanneer zij maatregelen neemt met het oog om die risico's in te perken, hen beperkingen oplegt in hun handelingsvrijheid. Gebrek aan kennis over oorzaak-gevolgrelaties en over de werkelijke effecten van ingrijpen zijn dan complicerende factoren. Immers, wetenschappelijke 
onderbouwing van de doeltreffendheid en doelmatigheid van maatregelen draagt bij aan de rechtvaardiging van ingrijpen in de handelingsvrijheid van burgers en bedrijven. Er ligt zowel het gevaar op de loer van niet ingrijpen waar dat achteraf bezien wel nodig was geweest, als omgekeerd van wel ingrijpen waar dat achteraf bezien niet nodig was geweest. De afweging hierbij wordt bovendien in toenemende mate in internationaal verband gemaakt, met name in de context van de EU. Enerzijds is de Nederlandse overheid in haar nationale milieubeleidsvorming dus gebonden aan internationale wet- en regelgeving. Dit kan implicaties hebben voor de gegroeide bestuurlijke verhoudingen en tradities: wellicht meer 'dirigisme' waar de trend bestaat uit decentralisatie en overdracht van verantwoordelijkheden. Anderzijds zal de Nederlandse overheid de nationale milieubeleidsvorming kunnen of moeten gebruiken om haar positie in de internationale beleidsvorming te bepalen. Daarbij kan het resultaat van de internationale beleidsvorming uiteraard afwijken van de Nederlandse consensus, en kunnen en zullen de Nederlandse gesprekspartners in toenemende mate ook hun eigen weg, buiten de Nederlandse overheid om, naar Brussel en Straatsburg weten te vinden.

Uit deze overwegingen zijn de volgende vraagstellingen af te leiden: in hoeverre zal de uitdaging die de milieuproblematiek stelt aan de Nederlandse samenleving in het algemeen, en de Nederlandse overheid in het bijzonder, in de komende jaren veranderen? Welke randvoorwaarden worden er vanuit de EU en de bredere internationale gemeenschap gesteld aan de ontwikkeling en uitvoering van het Nederlandse milieubeleid? In hoeverre is het huidige Nederlandse milieubeleid al toegesneden op de veranderende problematiek en de zich ontwikkelende randvoorwaarden? In het vervolg van dit rapport komen deze vragen nader aan de orde.

\subsection{OPBOUW VAN HET RAPPORT}

De opzet van het rapport is als volgt. Hoofdstuk 2 biedt een historisch overzicht van de ontwikkeling van het Nederlandse milieubeleid. De nadruk ligt op een typering van de problemen en op de factoren die de context bepalen waarin deze moeten worden aangepakt.

Hoofdstuk 3 schetst het analytische beleidskader van het rapport. Om te bezien aan welke voorwaarden 'goed beleid' in het algemeen moet voldoen, worden vier criteria geïntroduceerd: rechtmatigheid, doelmatigheid en doeltreffendheid, haalbaarheid en aanvaardbaarheid. Zij kunnen in hun onderlinge verhouding aanleiding geven tot spanningen en dilemma's. Bij de beleidsvorming en het scheppen van maatschappelijk en politiek draagvlak maakt de overheid actief gebruik van kennis en participatieprocessen.

Hoofdstuk 4 analyseert een zestal casussen. Daarin zijn sommige milieuproblemen $w e l$, en andere die niet binnen de bestaande beleidskaders beheersbaar gemaakt. Een deel van de casussen speelt voornamelijk op nationaal niveau, een ander deel voornamelijk op internationaal niveau. De empirische onderbouwing 
van de casussen is in een apart werkdocument ondergebracht (WRR 2003 b). De casuïstiek laat zien hoe op uiteenlopende gebieden is gepoogd door de inzet van kennis en participatie aan de criteria voor goed beleid te voldoen.

Hoofdstuk 5 is een uitwerking van de problemen die in hoofdstuk 4 zijn geformuleerd, met een accent op de hardnekkige en nieuwe milieuvraagstukken. Het zou te eenvoudig zijn te pretenderen om voor die omvangrijke problematiek een kant en klaar 'recept' te kunnen aanreiken. Het betoog dat in dit slothoofdstuk wordt ontwikkeld, is daarom ook primair een perspectief op de zoekrichtingen voor beleidsvorming met betrekking tot de moeilijke milieuproblemen. De vraag die in hoofdstuk 5 centraal staat is wat de meest geschikte probleemhantering is voor de nieuwe generatie van milieuproblemen. Deze zogeheten wicked problems hebben twee centrale kenmerken. In de eerste plaats gaat het om milieuproblemen die, veel meer dan de zintuiglijk waarneembare hinderproblemen uit het verleden, zijn omgeven met een relatief grote mate van causale onzekerheid. Bovendien manifesteren zij zich op een grensoverschrijdende territoriale schaal. Dit betekent dat ook de bestuurlijke context waarin naar oplossingen moet worden gezocht internationaal van aard is. In dit licht geeft het slothoofdstuk de richtingen aan volgens welke de nieuwe problemen moeten worden aangepakt. Dat geldt met name voor de (organisatie van de) kennisinbreng, voor de participatie en voor de organisatie, doorvertaling en beïnvloeding van de (internationale) besluitvorming. 


\section{MILIEUPROBLEMEN, MILIEUBELEID EN}

\section{KENNISIMPLICATIES}

\subsection{INLEIDING}

Dit hoofdstuk geeft een brede beschrijving van de milieuproblemen, beleidsontwikkelingen en kennisaspecten, zoals die in het feitelijk gevoerde milieubeleid van de afgelopen 32 jaar naar voren zijn gekomen.

In het milieubeleid zijn drie tijdsperioden te onderscheiden, die achtereenvolgens beginnen in 1970, 1988 en 1998; is er het in beleidsdocumenten neergelegd toekomstperspectief. De eerste twee ijkpunten liggen voor de hand. De jaren 1970 en 1988 laten een nieuw urgentiebesef zien. Juist rond die jaren is er een brede maatschappelijke en politieke steun voor een algemene beleidsprioriteit voor het milieu (Siraa et al. 1995: 235). Het Nationaal Milieubeleidsplan III (NMP) van 1998 luidt eveneens een nieuwe periode in: het geeft een evaluatie van het eind jaren tachtig ingezette milieubeleid en biedt ten dele een nieuw beleidsperspectief voor de toekomst.

De behandeling van iedere tijdsperiode in de paragrafen 2.2 tot en met 2.5 kent steeds drie onderdelen: de (gepercipieerde) aard van de problemen, de beleidsontwikkelingen, voor de twee latere perioden ook op Europees niveau, en de specifieke ontwikkelingen op het gebied van de milieukennis. Het Europese milieubeleid komt pas in de tweede en derde periode ter sprake, gezien de belangrijke impulsen die de Verdragen van Maastricht en Amsterdam in de jaren negentig aan het milieubeleid op dit niveau hebben gegeven. Paragraaf 2.5 behandelt het toekomstperspectief dat in recente beleidsdocumenten is neergelegd. De concluderende paragraaf 2.6 brengt enkele vragen en aandachtspunten naar voren die het milieubeleid de komende jaren waarschijnlijk zullen domineren, gegeven de recent in gang gezette ontwikkelingen.

\subsection{DE PERIODE 1970-1988}

\subsubsection{ALGEMEEN}

Milieuvervuiling is een gegeven dat nu eenmaal uit het menselijk handelen voortvloeit. Vormen van milieubeleid van de Nederlandse overheid bestaan dan ook al lange tijd. Men denke aan het stedelijk hygiënebeleid in de negentiende eeuw. De Hinderwet van 1875 had haar voorloper in het Fabrieksbesluit van 1824 . Nieuw is het concept van de milieuproblematiek en van het milieubeleid zoals dat in de jaren zestig van de twintigste eeuw ontstond, waarbij de natuurwetenschap een belangrijke initiërende rol vervulde. Maatschappelijk kreeg dit concept vooral betekenis in de tweede helft van de jaren zestig, waarbij twee ontwikkelingen elkaar versterkten. Allereerst was er de opkomst van een fundamentele discussie 
over de waarde van economische groei, over de relatie tussen arme en rijke landen en over het materialistische karakter van de consumptiemaatschappij. Ten tweede werden de negatieve gevolgen zichtbaar van de voortgaande industriële groei in termen van stank, geluidshinder en waterverontreiniging.

Het bekende rapport van de Club van Rome, als belangrijkste katalysator, hoeft hier niet herhaald te worden. De volgende punten vragen hier wel aandacht. Ten eerste was het rapport gebaseerd op een wetenschappelijk wiskundig model dat zeker voor niet-deskundigen de suggestie opwierp van een zuiver wetenschappelijk verklarend en voorspellend onderzoek. Pas veel later hebben de realiteitswaarde van dit model en de objectiviteit van de aannames die er aan ten grondslag liggen, in brede wetenschappelijke kring kritiek ondervonden. Ten tweede komt de vraag op waarom dit rapport juist in Nederland zo'n gunstige ontvangst heeft gekregen. Hiervoor zijn meerdere redenen aan te voeren. Gezien de grote bevolkingsdichtheid is in Nederland vanouds de milieubelasting per oppervlakte-eenheid relatief hoog. Door zijn ligging is Nederland extra gevoelig voor optredende internationale milieuvervuiling. Ten derde heeft Nederland een sterke beleidstraditie van wetenschappelijke, modelmatige onderbouwing van beleid, welke onderbouwing consensusvorming en pacificatie vergemakkelijkt. In die traditie maken wetenschappelijke rapporten die de ernst van de situatie eenduidig willen vaststellen, wellicht grotere indruk dan elders.

\subsubsection{DE AARD VAN DE PROBLEMEN}

Voordat de naoorlogse moderne industrialisatie op gang kwam, stond de milieuhinder in het teken van lokale, stedelijke problemen zoals besmettingsgevaar, ongezuiverd drinkwater en stankoverlast. In de belangrijkste milieuwetten avant la lettre, zoals de genoemde Hinderwet, waren de gemeenten dan ook de centrale actor. De daaropvolgende industriële expansie leidde rond 1970 tot problemen die meestal een bovenlokaal of regionaal karakter droegen en in bepaalde gevallen zelfs een internationaal niveau hadden, zoals de vervuiling van grote rivieren. In al deze gevallen bleven de milieunadelen wel voor iedereen zintuiglijk waarneembaar. Zeker in de beginfase vanaf 1970 werden milieuvraagstukken vooral gezien binnen de traditionele optiek van de volksgezondheid. In deze optiek ging het om afzonderlijke, nietsamenhangende risico's voor de gezondheid, die in hoge mate omkeerbaar waren.

In de jaren tachtig ontwikkelde zich in het beleid het idee van een tweede generatie van milieuproblemen: aantasting van de ozonlaag, broeikaseffect, verzuring, ontbossing en woestijnvorming. Het was bepaald niet zo dat de tweede generatie in de plaats kwam van de eerste generatie van problemen. Niet alleen waren problemen van de eerste generatie maar ten dele opgelost, de tweede generatie problemen betrof bovendien vaak de al bestaande problemen 'in een nieuw jasje gestoken'. Mede op basis van voortschrijdend wetenschappelijk inzicht werden de problemen geherformuleerd. Centraal stonden in deze optiek de volgende gezichtspunten: het multisectorale en wijdverspreide karakter van de problemen, de gevolgen voor het ecosysteem als geheel en hun mogelijke onomkeerbaarheid. 


\subsubsection{ONTWIKKELINGEN IN HET BELEID}

De eerste jaren stonden in het teken van de opbouw van een bestuurlijk apparaat. De nieuwe milieubeleidssector moest een positie zien te verwerven binnen de bestuurlijke gremia, zowel in relatie tot decentrale overheden als tot andere departementen. Belangrijker was de inhoudelijke aanpak. Begonnen werd met het saneren van de meest urgente vormen van aantasting van de volksgezondheid. Dit was een algemene trend. De Urgentienota van 1971 had haar equivalent in het Duitse Sofort-Programma. Het wegwerken van de milieuvervuiling op zich stond centraal - de samenwerking met degene die de vervuiling veroorzaakte zou pas vele jaren later het leidend motief worden, in het kader van het doelgroepen- en convenantbeleid.

Bij deze eerste fase pasten sectorale wetten van de klassieke snit, waarbij eenzijdig van overheidswege dwingende gedragsverplichtingen werden opgelegd, met de vergunning als centraal instrument. Deze verdere uitdijing van sectorwetten leidde in de vervolgjaren zeventig tot nieuwe problemen. Allereerst ontstond er onduidelijkheid over de coördinerende rol van de voor het milieu verantwoordelijke minister, in het bijzonder tegenover de collega's die verantwoordelijk waren voor het ruimtelijk (inrichtings)beleid. Juist in de confrontatie met dit beleid werd het milieubeleid ook steeds meer onderdeel van ruimtelijk beleid en verloor het milieubeleid de traditionele oriëntatie op het gezondheidsbeleid.

De gebrekkige samenhang van de sectorwetten gaf verder niet alleen een verzwaring van de bestuurlijke lasten en ondoorzichtigheid, maar had ook inhoudelijke bezwaren, in de vorm van afwenteling van problemen in de ene milieusector naar de andere. Te gemakkelijk was men er vroeger van uitgegaan dat iedere vermindering van milieulasten op zich een goede zaak was, zonder dat met de neveneffecten naar andere compartimenten rekening werd gehouden. Bovendien ontstond langzamerhand het besef dat het beleid zich te veel had geconcentreerd op de totstandkoming van milieuwetten op zich, hetgeen, gezien de intern-bestuurlijke strijd die dit kostte, overigens ook begrijpelijk was.

Voor de eerder gesignaleerde problemen werd in de loop van de jaren tachtig een gedeeltelijke oplossingsrichting gevonden:

1 Er kwam een sterkere externe, vooral organisatorische integratie binnen het ruimtelijke beleid tot stand.

2 De milieuwetgeving zelf werd intern geïntegreerd door middel van de Wet algemene bepalingen milieuhygiëne (WABM).

3 De uitvoeringsproblematiek werd aangepakt middels een beter toezicht op en facilitering van met name decentrale uitvoering, een zekere deregulering en versterking van de Rijksinspectie.

Tegelijkertijd was er een (begin van een) omslag op twee principiële punten, die de weg voorbereidden voor de nieuwe fase vanaf 1988 . Het eerste punt betrof de beleidsattitude. De blik werd minder overheidsintern gericht en verschoof naar 
de rol van maatschappelijke actoren bij de uitvoering van milieubeleid. De tweede ontwikkeling had direct te maken met het genoemde karakter van de tweedegeneratieproblematiek, en betrof de ontwikkeling van integrale langetermijnplannen, de zogenoemde Indicatieve Meerjarenprogramma's (IMP's). Deze twee ontwikkelingen komen uitvoeriger ter sprake in paragraaf 2.3.

\subsubsection{KENNISASPECTEN}

In de beginfase was er bij de overheid weinig milieudeskundigheid, en was er sprake van een flinke achterstand ten opzichte van het bedrijfsleven (Siraa et al. 1995: 262 e.v.). Daar kwam verandering in door het werk van drie instanties die de milieukennis ten behoeve van het overheidsbeleid aanzienlijk versterkten.

Allereerst was er de Rijksinspectie, die vooral in de beginfase een initiërende rol speelde. Na de totstandkoming van de eerste generatie milieuwetten had de inspectie een functie in de uitvoeringspraktijk, in het bijzonder ten opzichte van de decentrale overheden; het ging met name om bewaking, ondersteuning en advisering.

Ten tweede kunnen de externe adviescolleges worden genoemd. In 1973 werd een voorlopige Centrale Raad voor Milieuhygiëne opgericht, die in 1981 een definitieve grondslag kreeg. Deze raad bestond uit vertegenwoordigers van maatschappelijke organisaties, lagere overheden en deskundigen. De raad had een adviserende, een onderzoeks- en een voorlichtende taak, in de vorm van het opstellen van jaarlijkse milieuverslagen. De moeizame consensusvorming leidde echter bepaald niet tot goed uitvoerbare beleidsadviezen. Als 'inspraakraad' gaf dit adviescollege het parlement vooral inzicht in de maatschappelijke pluriformiteit van opvattingen. Gezien deze beperking in de advisering werd daarnaast in de jaren tachtig een externe deskundigencommissie voor de lange termijn ingesteld. Uiteindelijk werden beide colleges in 1993 samengevoegd in één adviesraad voor het milieu, die zich sterker moest richten op onafhankelijke advisering. In de jaren negentig ging deze adviesraad op in één adviesraad voor het gehele VROMterrein.

Ten derde waren er de wetenschappelijke onderzoeksinstituties van de rijksoverheid, die in deze periode vooral op ad hoc-basis technisch ondersteunend onderzoek verrichtten. In 1983 werd het Rijksinstituut voor Volksgezondheid en Milieu (RIVM) opgericht. Het instituut was het product van een fusie van drie instituties die werkzaam waren op terreinen als de drinkwatervoorziening en de afvalverwerking. Een regeling van taak en organisatie van dit instituut werd wel in het vooruitzicht gesteld, maar kwam er in deze periode nooit. De verouderde, sterk hiërarchische regelingen voor de vroegere instituties bleven van kracht. Het instituut kreeg de status van directoraat-generaal van het toenmalige ministerie van wvc, maar fungeerde vanaf het begin ook als centraal onderzoeksinstituut voor het milieubeleid van de gehele rijksoverheid. Van een werkelijke planbureaufunctie was voor het RIVM in deze periode nog geen sprake. 


\subsubsection{CONCLUSIES}

De jaren zeventig stonden duidelijk in het teken van de opbouw van het milieubeleid als eigen beleidssector binnen (met name) de rijksoverheid. Overheersend was de strijd om een eigen bestuurlijke erkenning en om een eigen juridische en kennisinfrastructuur. De bestrijding en beheersing van concrete vormen van milieuschade op onderdelen stonden als doelen van beleid centraal. Inhoudelijk domineerde in deze eerste fase de gezondheidsoptiek.

De jaren tachtig lieten vooral een interne versterking van de milieusector als geheel zien. Er kwam een grotere nadruk op de effectiviteit van het milieubeleid; de interne samenhang op de drie territoriale niveaus werd versterkt; er volgden aanzetten tot meer integrale planning middels de IMP's en de WABM. Ook richtte men de blik minder intern op de overheid en zag men de maatschappelijke veroorzakers van milieuschade gaandeweg meer als beleidspartners. Al deze ontwikkelingen kristalliseerden zich in de volgende periode verder uit.

\subsection{DE PERIODE 1988-1998}

\subsubsection{ALGEMEEN}

De nieuwe fase van maatschappelijk urgentiebesef had meerdere oorzaken, zoals de ramp van Tsjernobyl in 1986 en het rapport Our common future van 1987, uitgebracht door de Commissie Milieu en Ontwikkeling van de Verenigde Naties. Kernelementen van dit laatste rapport waren de introductie van het begrip duurzame ontwikkeling en het inzicht dat, binnen de randvoorwaarden van duurzaamheid, economische en ecologische gewenste processen niet elkanders tegengestelde waren, maar konden samengaan. Duurzame ontwikkeling werd in het rapport gedefinieerd als een ontwikkeling die voorziet in de behoeften van vandaag, zonder daarbij het vermogen van toekomstige generaties om in hun behoeften te voorzien, in gevaar te brengen.

De opheffing van de dichotomie tussen milieu en economie kreeg in de nieuwe optiek vooral gestalte doordat voordien steeds naar de nadelige gevolgen van de economie voor het milieu werd gekeken en nu meer naar de negatieve gevolgen van de milieuverslechtering voor de economie. In 1988 verklaarde minister-president Lubbers het milieubeleid tot vierde pijler van het gehele regeringsbeleid, naast de drie algemeen aanvaarde doelen van het sociaal-economische beleid. Ook de Sociaal-Economische Raad (SER) sprak zich in die zin uit. Procedureel vertaalde de nieuwe aanpak zich in een ander type beleidsvoorbereiding, die nieuw was voor het milieubeleid, maar in hoge mate een afgeleide was van de Nederlandse beleidstraditie op andere terreinen, te weten een beoogde, gedepolitiseerde dataverzameling ten behoeve van het beleid. Anders gezegd, het ging om een scherp onderscheid tussen wetenschappelijke beleidsvoorbereiding ten aanzien van de feiten en normatieve beleidsbepaling. Zoals eerder vermeld, 
kende het milieubeleid al voor 1989 een vorm van integrale langetermijnplanning, de IMP's. Het was evenwel de nieuwe vorm van onafhankelijke wetenschappelijke beleidsvoorbereiding die het beleid een nieuwe impuls gaf. 'Zuiver wetenschappelijk' was aangetoond dat de situatie hoogst ernstig was (minister Nijpels, aangehaald bij Siraa et al. 1995: 298 e.v.).

Organisatorisch kreeg de nieuwe aanpak gestalte in de inschakeling van het RIVM. Zowel het RIVM zelf als de politieke bewindslieden benadrukten het onafhankelijke, zuiver wetenschappelijke karakter van het beleidsvoorbereidende rapport Zorgen voor morgen, dat het RIVM in 1988 uitbracht (RIVM 1988: Voorwoord en $\mathrm{x}$-xi). In dat rapport zag het RIVM als zijn eigen taak: het beschrijven van de toestand van het Nederlandse milieu, inzicht verschaffen in te verwachten ontwikkelingen op korte en lange termijn, op basis van continue observatie en bestudering van de causale mechanismen. Het beheer van milieumeetnetten en wiskundige modellen gaven aan deze diagnose- en prognosetaak vorm (o.c.: xxi). Als integraal, langetermijnbeleidsplan gaf het NMP I hier op het rapport Zorgen voor morgen het beleidsmatige antwoord.

Dit beleid komt nog ter sprake. Wel is hier relevant te constateren dat het NMP in alle opzichten voortbouwt op het RIVM-rapport en de verzameling van feiten en kennis en de concepten waarbinnen deze verzamelingen zijn gemodelleerd, als wetenschappelijke gegevenheid overneemt en niet zelf beoordeelt. Dit is ook niet verwonderlijk, want aan de gehele procedure lag de gedachte ten grondslag dat een streng onderscheid tussen feiten en beleidsmatige waardering van de feiten mogelijk en nodig was.

\subsubsection{DE AARD VAN DE PROBLEMEN}

Het RIVM concipieert in het hiervoor genoemde rapport het milieu als een stelsel van reservoirs en stromen die deze reservoirs verbinden. Hierbinnen bestaan op verschillende niveaus meerdere kringlopen. Een verstoring van die kringlopen door menselijke activiteiten ten nadele van komende generaties is de kern van ieder milieuprobleem, in die zin dat negatieve en positieve terugkoppelingsmechanismen onvoldoende in evenwicht zijn en dat de laatste domineren. Het beleidsmatige antwoord ligt in deze redenering dan ook in het herstel van dit evenwicht, door de introductie van negatieve mechanismen. Het uitgangspunt hierbij is dat de milieugebruiksruimte eindig is en bovendien wetenschappelijk bepaalbaar is.

Binnen dit algemene concept wordt de aard van de problemen in het RIVMrapport en het NMP I als volgt geschetst. De problemen verschuiven van het lokale, regionale naar het bovennationale niveau. De waarden die in het geding zijn, veranderen: het gaat niet alleen meer om de aantasting van gezondheid en natuur, maar om het geheel van maatschappelijke en economische functies van het milieu. Nadrukkelijker wordt onderkend dat er meerdere, diffuse bronnen van milieuvervuiling zijn. In relatie met de schaalvergroting leidt dit ertoe dat er 
vaak langere tijd verloopt tussen de onderkenning van een milieuprobleem, de verandering aan de bron en het niet meer optreden van negatieve effecten. Verder onderkent men de gemeenschappelijke oorzaken van milieuproblemen.

Het NMP I formuleert de kern van de milieuproblematiek, bezien vanuit het oogpunt van duurzame ontwikkeling, aldus: het tegengaan van de afwenteling van milieuproblemen naar andere niveaus, zoals territoriale schaalniveaus, bevolkingsgroepen of komende generaties. Deze afwenteling heeft drie oorzaken: het openbreken of veranderen van stofkringlopen, intensief energiegebruik en het verwaarlozen van kwaliteit in productieprocessen en producten.

\subsubsection{ONTWIKKELINGEN IN HET NATIONALE BELEID}

De belangrijkste documenten zijn in dit verband het NMP I en II van respectievelijk 1989 en 1993. Het door het kabinet-Lubbers/Kok nader uitgebrachte NMP Iplus is vooral een operationele aanvulling. De beleidsinhoudelijke kaderstelling krijgt gestalte in het NMP I. Het NMP II is vooral een instrumentele uitwerking. NMP I is een strategisch beleidsplan dat het volgende doel voor de lange termijn formuleert: het bereiken van duurzame ontwikkeling binnen een generatie, vóór 2010 , in termen van saneren en preventie.

\section{Structurele aanpak voor de langere termijn}

Als kernvraag voor de beleidsaanpak op de langere termijn ziet het NMP I, zoals eerder naar voren kwam, de creatie van zodanige terugkoppelingsmechanismen dat er geen afwenteling plaatsvindt en de draagkracht van het milieu in stand blijft. Bij de keuze van het aangrijpingspunt van terugkoppeling hebben brongerichte maatregelen de voorkeur boven terugkoppeling via risicobeheersing van mogelijke nadelige effecten. Die effectbeheersing krijgt slechts een aanvullende rol, zoals bij het wegwerken van negatieve erfenissen uit het verleden, dan wel bij een uitdrukkelijke technologische of economische indicatie.

Bij de brongerichte maatregelen wordt enerzijds gekozen voor continuering van het traditionele beleid dat zich richt op emissiereductie en worden voor de verschillende niveaus reductiedoelen geformuleerd. Anderzijds moeten op termijn deze end-of-pipe-maatregelen plaatsmaken voor structureel brongericht beleid, waarbij 'procesgeïntegreerde' milieutechnologie de productie- en consumptiepatronen zelf wijzigt. Alleen dit type maatregelen past werkelijk bij de nieuwe perceptie van milieuproblemen en leidt tot integraal ketenbeheer, energie-extensivering en kwaliteitsverbetering, aldus het NMP I.

\section{Het operationele kortetermijnbeleid}

Hiervoor is in beide NMP's een systematiek ontwikkeld die uit het oogpunt van helderheid ook internationaal bewondering en navolging ondervindt. Op hoofdlijnen onderscheidt het milieubeleid negen inhoudelijke beleidsthema's. Aldus komt nog eens naar voren dat de reikwijdte van het milieubeleid geen optelsom is van departementale sectoren, maar dat milieubeleid een algemeen facetbeleid 
wil zijn dat het gehele overheidsbeleid raakt. Per thema worden wenselijke milieukwaliteiteisen geformuleerd; in relatie tot de feitelijke belasting voor het milieu, zoals aangegeven door het RIVM, worden op basis hiervan kwantitatieve doelen geformuleerd. Deze doelen zijn op te vatten als maatschappelijk gewenste eindresultaten van de uitvoering van het milieubeleid op een bepaald tijdstip. Deze doelen zijn vervolgens weer de basis voor afspraken met maatschappelijke doelgroepen over de voor hen geldende taakstelling. Ook kunnen doelen worden vertaald in taakstellingen voor specifieke regio's, waarover men afspraken met lagere overheden maakt.

\section{Instrumentarium}

De principiële verschuiving betreft vooral het van overheidswege sterker aanspreken van andere actoren - bedrijven, instellingen en burgers - op hun eigen operationele verantwoordelijkheid voor het milieu, gegeven de grondwettelijke eindverantwoordelijkheid van de overheid zelf. Het meer honoreren van verantwoordelijkheden van andere actoren betekent niet het volledig overlaten aan die anderen. De overheidsrol wordt niet zozeer minder, maar anders, met een grotere nadruk op kaderstelling, regievoering en toezicht.

Integratie, verbreding en differentiatie van het instrumentarium zijn de belangrijkste formele kenmerken van de instrumentele ontwikkelingen. De integratie wordt in een latere fase vooral bevorderd door de invoering van de Wet milieubeheer (WM) in 1993, die een procedureel kader biedt voor integrale wetenschappelijke voorbereiding door het RIVM, voor overheidsplanning en -programmering. In het bijzonder de periodiek voorgeschreven strategische beleidsplannen moeten richting geven aan het gebruik van het geheel van oude en nieuwe instrumenten.

Het klassieke model van directe publiekrechtelijke gedwongen gedragsregulering blijft in deze beleidsredenering als zodanig in stand, dat model boet alleen in aan dominantie. Extra aandacht krijgen:

1 de interne integratie van deze wetgeving, onder andere door deze wetten zoveel mogelijk onder te brengen in de algemene kaderwet;

2 een betere handhaving en globalisering van de regelgeving, zoals meer algemene regelgeving en minder gedetailleerde vergunningen;

3 een ander karakter van de vergunningen: zij moeten zich vooral richten op de te bereiken doelen en in de middelensfeer de vergunninghouder vrijer laten; verder krijgen de grote steden meer ruimte voor ontheffingen en experimenten.

Deze globalisering, veralgemening van regelgeving is overigens geen algemene lijn. Op bepaalde terreinen, met name de agrarische wetgeving, wordt de gedetailleerde regelgeving eerder versterkt dan afgezwakt. Een voorbeeld is de mestwetgeving. Verwezen zij naar het ter zake gestelde in hoofdstuk 4. 
De principiële verschuiving naar een meer kaderstellende, regisserende en toezichthoudende overheid komt het duidelijkst tot uiting in het horizontale instrument van het convenant, welk instrument in het NMP II centraal staat. De overheid blijft zelf verantwoordelijk voor de in het eigen plan gekozen themadoelen. Zij vertaalt die doelen vervolgens in overleg met de doelgroep - meestal (organisaties van) bedrijven - in taakstellingen, welke in convenanten bindend worden vastgesteld. Juist deze periode kenmerkt zich door een hausse aan convenanten. De geschetste principiële verschuiving blijkt eveneens uit de introductie van wettelijke globale milieuzorgplichten voor maatschappelijke actoren, die op zich een goede basis kunnen bieden voor een betere benutting van het privaatrecht voor milieubeleid, hetgeen overigens maar in beperkte mate is gebeurd.

De belangrijkste verbreding betreft vooral het geheel van de financiële, sociale en informatieve instrumenten. Deze worden met name ingezet bij de moeilijk bereikbare doelgroepen, zoals minder goed georganiseerde producenten en de burger als consument. Aanvankelijk ligt alle nadruk op sociale instrumenten, zoals voorlichting, educatie en overreding. Deze sterk morele, op bewustwording en verinnerlijking gerichte methode loopt echter snel tegen zijn grenzen aan, mede gezien kennistekorten inzake de sociaal-culturele determinanten van milieu(on)vriendelijk gedrag. Dit type instrumenten blijkt alleen onder speciale condities goed te werken, bijvoorbeeld indien de beoogde gedragsverandering geen hoge kosten in termen van tijd, geld, gemak en status met zich meebrengt en als er bovendien goede alternatieven voorhanden zijn, zo blijkt bij de evaluatie in het NMP II. Bovendien is er bij de consument een informatietekort; zijn eigen bijdrage aan milieuverbetering wordt veelal veel lager ingeschat dan die van andere actoren. In het bijzonder bij het op de burger als consument gerichte beleid laat deze periode een omslag zien naar verzakelijking, naar meer financieel-economische en informatieve instrumenten. Het eerste type instrumenten, zoals regulerende heffingen en gedifferentieerde belastingheffing op milieugrondslag, moet de consument confronteren met de reële milieukosten en hem stimuleren, respectievelijk ontmoedigen.

Als een vanzelfsprekende aanvulling op deze financiële 'incentives' worden daarnaast de informatieve verplichtingen voor alle actoren versterkt, teneinde de milieueffecten publiekelijk zichtbaar te maken. Voor overheden wordt een milieueffectrapportage verplicht. Regels voor producenten op punten als onderzoek, verslaglegging en informatieverschaffing, in de vorm van milieukeuren en certificaten, hebben een gelijke strekking. Ook hier is veelal sprake van een combinatie van overheids- en maatschappelijke verantwoordelijkheid; veelal ziet de overheid alleen toe op de aanwezigheid van adequate informatiesystemen zonder deze zelf in te richten of te beheren.

\subsubsection{KENNISASPECTEN}

Het succes van het rapport Zorgen voor morgen van 1988 heeft in hoge mate de verdere beleidsontwikkeling beïnvloed en heeft geleid tot continuering van dit 
soort RIVM-rapporten. De periodieke Milieuverslagen en Verkenningen van het RIVM beschrijven niet alleen de situatie, maar gaan ook in op de te verwachten maatschappelijke en economische gevolgen van milieuverslechtering en van het voorgenomen beleid. Op aandringen van het parlement is halverwege de jaren negentig ook de positie van het RIVM als onafhankelijk wetenschappelijk planbureau wettelijk vastgelegd. Gekozen is voor eenzelfde positionering als de al bestaande planbureaus.

Binnen de overheidsdienst krijgt het RIVM in deze wettelijke regeling uitdrukkelijk niet de status van zelfstandig bestuursorgaan (zbo). Bij een dergelijke constructie heeft de minister alleen bevoegdheden voorzover die bij wetgeving uitdrukkelijk zijn toegekend. De wetgever heeft bij het RIVM voor de tegenovergestelde figuur gekozen: het RIVM is alleen onafhankelijk voorzover de wetgever dit bepaalt. Voor het overige gelden de normale hiërarchische lijn en de ministeriële verantwoordelijkheid (Wetsontwerp op het RIVM, MVT: 4). De beoogde zelfstandigheid betreft met name de professionele, wetenschappelijke autonomie en beoogt een directe politieke invloed op de inhoud van de onderzoeken te voorkomen (MVT: 5). Dit is in de wet aldus geformuleerd dat de minister de ambtelijke leiding van het RIVM geen aanwijzingen mag geven ten aanzien van de methode van onderzoek en verslaglegging. Een hiërarchische sturing binnen het RIVM zelf is hier uitdrukkelijk niet mee uitgesloten. Dit sluit bovendien niet uit dat de minister en de directeur-generaal van het RIVM afspraken maken over de modellering van rapportages om de voor beleid en toezicht relevante conclusies zo helder mogelijk naar voren te brengen (MVT: 5).

Binnen de beperking van respect voor de professionele autonomie behoudt de minister finale zeggenschap over het activiteitenprogram en kan hij het RIVM instructies geven. Verder is voorzien in verplichte samenwerking met de overige planbureaus. Ten aanzien van de door het RIVM op te stellen periodieke prognostische milieuverkenningen krijgt het RIVM in de Wet milieubeheer uitdrukkelijk opdracht meerdere, meer en minder waarschijnlijke scenario's te ontwikkelen. Ook regelt de wet uitvoerig de inrichting van de evaluerende, periodieke verslagen die het RIVM moet opstellen. De minister kan aanwijzingen geven over de inschakeling van andere overheidsinstanties, en meer inhoudelijk, over de maatschappelijke ontwikkelingen en onderwerpen die 'bij de grondslag van de beschrijving aan de orde moeten komen' (art. $4 \mathrm{wm}$ ). Voor het overige is het RIVM inhoudelijk vrij (art. 2).

\section{Conclusie}

Als conclusie kan gelden dat de wetgever een ingewikkeld compromis heeft bedacht tussen onafhankelijkheid, beleidsnabijheid en instrumenteel gebruik van het RIVM. Juist op een terrein waarin kaderstelling en modellering van de werkelijkheid zo belangrijk zijn, moet worden geconstateerd dat gezien de hiërarchische relatie met de minister en gezien de beoogde samenwerking met andere planbureaus van de overheid het RIVM op dit punt helemaal niet zo vrij is. Een zekere gemeenschappelijkheid in de analytische modellen van de onderzoeksin- 
stituten en de beleidsmodellen van de overheid wordt binnen deze wettelijke structuur eerder bevorderd en beoogd dan afgewezen.

\subsubsection{ONTWIKKELINGEN OP EUROPEES NIVEAU}

Het begin van de juridische erkenning van een eigen milieubeleid van de Europese Gemeenschappen (EG) ligt bij de totstandkoming van de Europese Akte in 1987. De Verdragen van Maastricht (1991) en Amsterdam (1997) hebben vervolgens de positie van het milieubeleid aanzienlijk versterkt. Sinds het Verdrag van Amsterdam is het bevorderen van een evenwichtige, duurzame economische ontwikkeling een van de hoofddoelen van de EU (art. 2 EGVerdrag). In dit beginselartikel is bovendien vastgesteld dat de eisen van een goed milieu in het gehele beleid van de EU moeten worden geïntegreerd, met het oog op duurzame ontwikkeling. Daarbij moet voor dit gehele Europese beleid worden uitgegaan van een hoog niveau van milieubescherming en verbetering van de kwaliteit ervan (art. 2 EG-Verdrag); de bedoeling is dat aldus moet worden voorkomen dat het nationale beleid op een gemiddeld niveau Europees zou worden geharmoniseerd, en progressieve landen als Nederland hun beleid in neerwaartse zin moeten bijstellen.

Uit kennisoogpunt is van belang dat de EU in haar algemene milieubeleid rekening moet houden met de beschikbare wetenschappelijke gegevens, terwijl bij de op marktharmonisatie gerichte milieumaatregelen in het bijzonder met nieuwe wetenschappelijke inzichten moet worden rekening gehouden. Ook wanneer nationale overheden voor een specifieke eigen problematiek zelf strengere milieumaatregelen willen nemen, moeten zij deze baseren op nieuwe wetenschappelijke gegevens. Bovendien mogen deze nationale maatregelen geen hinderpaal zijn voor de werking van de interne markt.

\section{Beginselen, met name het voorzorgsbeginsel}

In algemeen-juridische zin is het interessant dat in het recht van de EU, meer dan in het Nederlandse recht, enkele inhoudelijke beginselen van goed milieubeleid zijn neergelegd, die doorwerken in regelgeving, bestuur en rechtspraak. In het bijzonder heeft het Verdrag van Maastricht een uitbreiding te zien gegeven. De relatieve achterstand in de Nederlandse milieuwetgeving, die vanouds sterk procedureel gericht is, overweegt de regering overigens op termijn weg te nemen (Nota Met recht verantwoordelijk 2001: 54 e.v.).

In het EG-Verdrag gaat het vooral om de trits van het beginsel 'de vervuiler betaalt', het preventie- en het voorzorgsbeginsel. Het ook genoemde beginsel van voorkeur voor bestrijding aan de bron is meer een afgeleide van het preventiebeginsel. Het beginsel 'de vervuiler betaalt' heeft betrekking op de situatie dat de milieuaantasting al is opgetreden, bij het preventiebeginsel is het ontstaan van deze aantasting zonder nader ingrijpen zeker: in beide gevallen is derhalve het verband tussen oorzaak en gevolg bekend. Alleen dan zijn de beginselen van toepassing. Het voorzorgsbeginsel heeft betrekking op de situatie waarbij 
(toekomstige) milieuaantasting, gegeven de stand der wetenschap, juist niet onomstotelijk kan worden vastgesteld, er zijn alleen indicaties zijn over het verband tussen oorzaak en gevolg (Drupsteen 2000: 216).

Het EG-Verdrag definieert dit beginsel niet. Met name de Europese Commissie (200o) heeft een algemeen aanvaard kernelement goed weergegeven, te weten de plicht tot een afweging vooraf:

“Indien ten gevolge van toetsbare kennis een redelijk vermoeden bestaat dat een bepaalde handeling een ongewenst gevolg heeft voor mens of milieu, maar het causale verband tussen handeling en gevolg niet met volledige zekerheid kan worden aangetoond, dan is degene die over het toelaten of verrichten van de handeling beslist, verplicht een controleerbare afweging te maken of het risico al dan niet genomen kan worden of het gevolg zal intreden.”

Het tweede element, de gewenste richting van de afweging, is hiermee nog niet gegeven. Uit (inter)nationale jurisprudentie blijkt dat hier andere beginselen van redelijkheid, evenredigheid en zorgvuldigheid gelden en dat soms is vereist dat verbiedende maatregelen worden genomen (Lambers 200o). Zo komt in ieder geval naar voren dat het beginsel wel een handreiking biedt voor de vraag hoe om te gaan met wetenschappelijke onzekerheid, maar bepaald niet meer. Onduidelijk is wanneer het beginsel precies van toepassing is en derhalve de plicht ontstaat om het risico vooraf te onderzoeken en af te wegen. Moet er bijvoorbeeld sprake zijn van een redelijk vermoeden van ernstige milieugevolgen? Daarenboven is evenmin de richting van de afweging vooraf gegeven.

\subsubsection{CONCLUSIES}

Deze periode laat verschillende nieuwe ontwikkelingen zien die in hun onderlinge relatie wellicht onvoldoende erkende spanningen oproepen.

\section{De perceptie van problemen}

Uit de relatie tussen het rapport Zorgen voor morgen van het RIVM en het beleidsplan NMP I wordt duidelijk hoezeer de wetenschappelijke modellen waarbinnen de problemen door het RIVM worden beschreven, in het beleidsplan zonder meer worden overgenomen en ook gaan fungeren als beleidsmodellen. Hierbij zij bedacht dat het RIVM uitgaat van een hoog wetenschappelijk aspiratieniveau en met name de milieugebruiksruimte ook wetenschappelijk bepaalbaar acht. Bovendien is van belang dat gezien de wettelijke regeling van het RIVM dit instituut alleen op enkele professionele onderdelen echt autonoom is en als overheidsdienst fungeert in opdracht van de minister. Een oneigenlijke vermenging van wetenschappelijke en beleidsmodellen is dan een reëel risico.

De opkomst van het voorzorgsbeginsel in de bestuurlijke en juridische praktijk laat een andere spanning zien. Dit beginsel voorziet juist in de behoefte aan een beleidsmatige handreiking in de situatie waar de wetenschap geen onomstotelijke relaties tussen oorzaak en gevolg kan aantonen. 


\section{Beleidsinhoudelijke verschuivingen}

De belangrijkste ontwikkeling is in deze periode de versterking van het facetkarakter van het milieubeleid. Het beginsel van duurzame ontwikkeling wordt een algemeen uitgangspunt voor het gehele, ook economische beleid. Het duidelijkst is deze ontwikkeling op EU-niveau waarneembaar, waar enkele milieudesiderata sinds het Verdrag van Amsterdam onderdeel zijn van de algemene beginselartikelen van het Europese Verdrag.

Ook hier zijn er spanningen, die naar voren komen in het NMP I. Op operationeel niveau vindt er nog geen scherpe afweging plaats tussen desiderata ten gunste van het milieu en wenselijkheden vanuit andere sectoren, met name het economische beleid. De gestelde doelen en normen worden afgeleid van wat primair uit milieuoogpunt wenselijk is. Juist duurzame ontwikkeling als één pijler van regeringsbeleid zou idealiter tot deze bredere afweging moeten leiden. In die zin blijft toch nog in hoge mate sprake van milieubeleid als sectorbeleid.

\section{Procedurele ontwikkelingen}

De belangrijkste nieuwe ontwikkelingen zijn de systeemrationele, wetenschappelijke aanpak, het participatiebeginsel en de inhoudelijke rechtsbeginselen van milieubeleid. De eerste ontwikkeling betreft de beleidsvorming: wetenschappelijke beleidsvoorbereiding die doorwerkt in de overheidsplanning en -programmering. De tweede ontwikkeling heeft betrekking op de beleidsuitvoering, die geschiedt in samenwerking met de maatschappelijke actoren, vooral in de vorm van convenanten. Tussen beide ontwikkelingen bestaan uiteraard spanningen. Het is één zaak om systeemrationeel van thema naar doelen en normen te redeneren, maar de toedeling van uitvoerende taken aan maatschappelijke doelgroepen is een zaak van onderhandelen en wordt bepaald door een geheel andere rationaliteit, zoals de machts- en belangenconstellatie.

Bovendien roept de uitbreiding van het instrumentarium vragen op. $\mathrm{Zij}$ gaat niet gepaard met de beleidsmatige ontwikkeling van een goed selectiekader dat duidelijk maakt welk type interventie bij welk type probleem past.

Al met al kan deze periode worden gekenschetst als een belangrijke, nieuwe fase in een leer- en zoekproces, waarbij verschillende in gang gezette ontwikkelingen niet alleen oplossingen bieden, maar zeker in hun onderlinge relatie ook vragen oproepen.

\subsection{DE PERIODE VANAF 1998}

\subsubsection{DE AARD VAN DE MILIEUPROBLEMEN}

Het NMP III geeft een indicatie van de aard van de overgebleven hardnekkige problemen die nog steeds in onvoldoende mate zijn opgelost. Het beleidsplan noemt de volgende bepalende factoren (NMP III 1998: 29): 
1 De uitvoering geeft problemen, gezien vooraf onvoorziene financiële en bestuurlijke kosten en juridische complicaties; een voorbeeld is het bodemsaneringsbeleid.

2 Het instrument van het convenant is slecht toepasbaar, gezien de moeilijke benaderbaarheid van de desbetreffende doelgroepen. Dat heeft ten eerste te maken met de afwezigheid van een sterke, eenvormige organisatie, zoals in (delen van) het midden- en kleinbedrijf. Ten tweede bemoeilijkt de diffuse veelvoud van bronnen van vervuiling, zoals bij geluidshinder, het bereiken van de doelgroepen. In beide gevallen zijn moeilijk afspraken te maken met de veroorzakers van de vervuiling.

3 De milieuproblemen kenmerken zich door een grote afstand van de bevolking, hetzij ruimtelijk, hetzij in de tijdsdimensie. In de ruimtelijke sfeer denke men aan problemen op bovennationaal niveau: alleen op dat niveau kunnen oplossingen worden gevonden. In de sfeer van tijdsduur kan worden gedacht aan een probleem als de vermindering van biodiversiteit: de nadelen zullen pas op zeer lange termijn zichtbaar worden.

4 De oplossing van de milieuproblemen vraagt om een structurele doorbreking van de bestaande productie- en consumptiepatronen.

Als relatief nieuw probleem signaleert het beleidsplan dat de in de jaren negentig geïntensiveerde economische ontwikkelingen en de bevolkingsgroei het gevaar oproepen dat de behaalde milieuwinst wordt ingehaald door volumegroei, zoals toenemende mobiliteit, energieverbruik en ruimtebeslag. De nu enigszins gerealiseerde ontkoppeling tussen milieuvervuiling en economische groei is geen verworvenheid, maar zal in de toekomst steeds opnieuw bevochten moeten worden, aldus dit NMP. Vanuit deze visie worden in dit NMP de gedrags- en institutionele elementen in de perceptie van de milieuproblematiek versterkt. De gedragscomponent is vooral aan de orde bij de vraag van de effectiviteit van faciliterende, stimulerende instrumenten, waar convenanten weinig functioneel zijn.

\subsubsection{ONTWIKKELINGEN IN HET NATIONALE BELEID}

In het NMP III is in hoge mate sprake van voortzetting van het in NMP I en II uitgezette beleid, zowel op doel- als op instrumenteel niveau. Te noemen zijn de verbetering van de kwaliteit en de naleving van wetgeving en het beleid inzake convenanten.

Voor het lokale en regionale niveau voorziet dit NMP dat het beleid een nieuwe fase ingaat. De nadruk komt te liggen op het beheer van het inmiddels schoongemaakte milieu. Alleen een beperkt aantal beleidsterreinen, zoals geluidshinder, bodemsanering en verdroging, zal nog lange tijd in de saneringsfase blijven. Dit lokaal en regionaal beheer vergt, aldus dit document, meer differentiatie en flexibiliteit in het beleid en een sterkere samenhang met het algemene ruimtelijke beleid. Om de betrokkenheid van de burger te vergroten, moet het milieubeleid op dit onderdeel worden ingebed in een algemeen beleid voor de kwaliteit van de fysieke leefomgeving. Lagere overheden krijgen daartoe meer bevoegdheden. 
Met het oog op de moeilijk bereikbare doelgroepen pleit het rapport voor een intensiever gebruik van financieel-economische instrumenten. Dit geldt ook voor de initiërende milieustrategie op internationaal niveau.

\subsubsection{KENNISASPECTEN}

In deze periode verschuift de aandacht van de wetenschappelijke onderbouwing van het eigen overheidsbeleid en de beleidsuitvoering naar verbreding en verdieping van de kennisontwikkeling uit een oogpunt van duurzame ontwikkeling. Meer dan vroeger wordt in dit NMP een relatie gelegd met het algemene wetenschaps- en technologiebeleid. De verbreding krijgt gestalte in de intensivering van het sociaal-cultureel onderzoek naar de maatschappelijke facetten van de milieuzorg. De verdieping betreft de accentverlegging naar fundamenteel onderzoek, dat wil zeggen de ontwikkeling van nieuwe wetenschappelijke concepten die op termijn tot structurele technologische doorbraken moeten leiden in termen van herontwerp, functie- en systeeminnovatie.

Deze verschuiving in aandacht maakt, aldus het NMP III, een aantal klassieke vragen weer actueel: de wenselijke 'incentives' die dit onderzoek bevorderen, de rol van de overheid als behartiger van het publiek belang, de tijdshorizon van dit soort onderzoek, en de internationale samenwerking en taakverdeling.

\subsubsection{ONTWIKKELINGEN OP EUROPEES NIVEAU}

Deze periode staat vooral in het teken van een verdere uitwerking van de principiële herziening van de plaats van het milieubeleid in het Verdrag van Amsterdam. Zo besluit de Europese Raad in 1998 dat de Europese Commissie bij belangrijke beleidsvoorstellen een beoordeling van het milieueffect moet toevoegen. Het proces van nadere regelgeving wordt geïntensiveerd, vooral in de vorm van kaderrichtlijnen. In 1999 concludeert de VROM-raad dat 70 tot 80 procent van de Nederlandse regelgeving direct of indirect door de EU wordt bepaald.

Bovendien worden op Europees niveau steeds meer andere instrumenten ingezet, zoals convenanten en heffingen. Speciale vermelding verdient de in 1999 in werking getreden IPPC-Richtlijn 96/61 (Integration, Pollution, Prevention and Control), die een integrale aanpak beoogt van de milieuverontreiniging van grote bedrijven. Zowel in Nederland als in andere Europese landen vraagt de uitvoering van deze richtlijn om aanpassingen in de nationale wetgeving. Nog een ander aspect van de regeling maakt duidelijk hoezeer deze regeling ingrijpt in het nationale beleid. Het in vele landen geldende beginsel van een zo hoog mogelijke milieubescherming krijgt in deze regeling een veel specifiekere uitwerking in het beginsel van bescherming overeenkomstig het principe van de best aanwezige technieken (het zgn. BAT-principe). Beide beginselen zijn daarom zo belangrijk omdat zij bij het stellen van regels en vergunningsvoorwaarden de afweging bepalen wat uit het oogpunt van milieu wenselijk en wat bedrijfseconomisch haalbaar is. De Europese regeling gaat er uitdrukkelijk van uit dat het gaat om de 
best aanwezige technieken op Europees niveau. De Europese Commissie krijgt de plicht om het BAT-principe in zogeheten reference documents uit te werken, teneinde de uitwisseling van informatie tussen de lidstaten over de best aanwezige technieken te bevorderen. Deze ontwikkeling leidt niet alleen tot Europese harmonisatie van nationale regelgeving, bestuur en rechtspraak, maar ook tot de ontwikkeling van gemeenschappelijke Europese kennis- en informatiestromen.

Verder is in dit verband het Verdrag van Aarhus van 1998 van belang. Dit verdrag is ondertekend door de EU en door 35 Europese en Aziatische nationale overheden. Het verdrag betreft de toegang tot informatie, de inspraak en de toegang tot de rechter in milieuzaken. Nederland voldoet grotendeels aan de verdragsverplichtingen. Het punt is dat nu ook in binnenlandse aangelegenheden de wijze van besluitvorming in hoge mate aan de nationale beleidsautonomie is onttrokken. Eind 2000 kan worden geconcludeerd dat Europees beleid en recht, met name via gerechtelijke uitspraken, ook de facto een centrale rol spelen in de milieubescherming en sterk ingrijpen in de machts- en belangenstrijd op nationaal niveau. De voorbeelden zijn legio: de Nitraatrichtlijn, de natuurbescherming, het bestrijdingsmiddelenbeleid en het beleid inzake waterverontreiniging.

\subsubsection{CONCLUSIES}

Wat de aard van de problemen betreft, laat met name het NMP III meer dan voorheen een scheiding zien tussen enerzijds lokale en regionale problemen, die van een saneringsfase overgaan in een beheersfase, en anderzijds de overgebleven hardnekkige en nieuwe problemen. Nog sterker dan in NMP I en II krijgt het milieubeleid een facetkarakter en wordt de relatie tussen economische groei en milieuverbetering sterker benadrukt. Het gaat in deze visie minder eenzijdig om de eigen eisen die het milieu aan de economie stelt, maar meer om het steeds opnieuw vinden van slimme wegen om economische groei en milieuverbetering te doen samengaan.

Bestuurlijk wordt een al eerder in gang gezette beweging vooral in deze periode manifester, te weten de differentiatie van schaalniveaus. Voor de problemen die in de beheersfase komen, krijgen lagere overheden een zwaardere taak. In wat traditioneel 'binnenlands' beleid heet, wordt de EU een steeds meer cruciale factor. De EU drukt zowel een stempel op de inhoud als op de vorm van het voorheen nationale milieubeleid. 


\subsection{TOEKOMSTPERSPECTIEF}

\subsubsection{INTERNATIONALE BELEIDSPERSPECTIEVEN}

Beleidsinitiatieven vanuit de Organisatie voor Economische Samenwerking en Ontwikkeling (OESO)

In mei 2001 stellen de milieuministers van de OESO een strategie voor het milieubeleid vast voor de periode tot 2010, die resulteert in afgesproken doel- en taakstellingen voor de OESO en de afzonderlijke staten. Een drietal typen problemen wordt onderkend:

1 de min of meer opgeloste problemen, met name klassieke vormen van industriële vervuiling, zoals lucht- en waterverontreiniging;

2 potentiële problemen die zijn omgeven met veel onzekerheid, zoals gevaarlijke stoffen, de milieu-implicaties van de biotechnologie en de sterke volumegroei in mobiliteit en energieverbruik;

3 hardnekkige, urgente problemen zoals het broeikaseffect en de afnemende biodiversiteit.

Het eerste type problemen zet het licht op groen, het tweede type op oranje en het derde op rood.

In de remediesfeer ontwikkelt men vervolgens een viertal criteria voor ecologische duurzaamheid:

1 behoud van het regeneratievermogen van vernieuwbare hulpbronnen;

2 de noodzaak om niet-vernieuwbare hulpbronnen te vervangen door die welke zich wel voor regeneratie lenen;

3 het tegengaan van gevaarlijke stoffen die de verwerkingscapaciteit van ecosystemen te boven gaan;

4 het vermijden van onomkeerbare, voor het milieu negatieve processen.

Er volgen vijf doelen die worden uitgewerkt in taakstellingen voor de OEso en de lidstaten:

1 Efficiënt beheer van natuurlijke hulpbronnen. Dit wordt uitgewerkt voor de prioritaire aandachtsgebieden: klimaat, drinkwater en biodiversiteit.

2 Ontkoppeling van milieuverlies en economische groei. In het bijzonder moet men voorkomen dat de behaalde milieuwinst wordt tenietgedaan door een volumegroei van consumptie en productie. Prioritaire aandachtsgebieden zijn landbouw, transport, energie, visserij, bosbouw en toerisme.

3 Verbetering van de informatiesystemen ten behoeve van het beleid. Dit betekent:

a betere indicatoren en monitoring-systemen voor de uitvoering;

b de gewenste doorwerking van milieueffecten in economische kosten- en batenanalyses en rekeningen;

c op de toekomst gerichte kennisontwikkeling;

$d$ het verspreiden van deze kennis en informatie tussen landen. Vooral op dit laatste punt heeft de OESO een belangrijke ondersteunende taak. Lidstaten hebben een belangrijke functie bij het openbaar maken van deze kennis, 
opdat de burger zich een zo goed mogelijk beeld kan vormen van de milieusituaties en noodzakelijk beleid.

4 Versterking van de relatie tussen milieu- en sociaal beleid op punten als gezondheid en veiligheid, verstedelijking, milieuaspecten van sociale rechtvaardigheid en participatie. In de driehoek tussen economische, sociale en milieuontwikkeling is juist de relatie tussen deze twee laatste aspecten in het beleid verwaarloosd. Bij de uitwerking krijgen vooral toegankelijke informatie, brede maatschappelijke deelname in de besluitvorming en de toegang tot de rechter grote aandacht.

5 Versterking van het milieubeleid op wereldniveau, in het bijzonder door:

a het ondersteunen van landen in ontwikkeling met een beperkte institutionele capaciteit op milieugebied;

$\mathrm{b}$ het versterken van de milieudimensies in economische organisaties als de Wereldhandelsorganisatie (WTO);

c het verder ontwikkelen van (niet-bindende) richtlijnen voor multinationale bedrijven.

\section{Beleidsinitiatieven vanuit de EU}

In juni 2001 heeft de Europese Raad een voorstel van de Europese Commissie aangenomen om te komen tot een Europese strategie voor duurzame ontwikkeling. Over de aard van de milieuproblemen meldt het besluit weinig nieuws: het benadrukt het mondiale en langetermijnkarakter van de problemen, waarbij Europa een wereldwijde voortrekkersrol moet vervullen. Nieuw is vooral het beleidsperspectief, waarvoor de juridische basis in het Verdrag van Amsterdam is gelegd, welk verdrag duurzame ontwikkeling tot een van de kerntaken van de EU maakt. Duurzaamheid wordt breed opgevat, waarbij de eisen van sociale, economische en ecologische duurzaamheid elkaar conditioneren. Het gaat om een aanhoudende economische groei die maatschappelijke vooruitgang bevordert en milieuvriendelijk is, om een sociaal beleid dat de economische prestaties ondersteunt en om een milieubeleid dat kosteneffectief is.

Grote nadruk krijgt een tweede 'Amsterdams' beginsel, te weten het principe van de externe integratie van milieubeleid. Milieubeleid is algemeen facetbeleid dat met name moet doorwerken in het sectorbeleid voor landbouw, visserij en vervoer. Dit vraagt om een meer integraal beleid, met als belangrijke elementen een goede wetenschappelijke onderbouwing en een vroegtijdige dialoog met betrokkenen, met name consumenten. Algemeen facetbeleid voor het milieu moet een positie krijgen die gelijkwaardig is aan die van het sociaal en economisch beleid.

Als ecologische hoofdprioriteiten worden genoemd:

1 De bestrijding van klimaatveranderingen en de bevordering van het gebruik van schone energie. Dit kan worden bereikt door middel van de naleving van het Kyoto-Verdrag, de afschaffing van subsidies op fossiele brandstoffen, een nieuw systeem van energieheffingen en verhandelbare $\mathrm{CO}_{2}$-vergunningen.

2 De vermindering van volksgezondheidsrisico's. Dit wordt onder andere uitge- 
werkt in de verbetering van de voedselveiligheid en -kwaliteit, de beperking van de effecten van gevaarlijke stoffen, een herziening van het landbouwbeleid, met meer nadruk op de kwaliteit van productiemethoden en op output en betere voorlichting en bewustwording van de consument.

3 Een verantwoordelijk beheer van natuurlijke hulpbronnen. Belangrijke terreinen zijn ook hier het landbouw- en visserijbeleid, alsmede het geïntegreerd productbeleid, ter vermindering van afval, en de invoering van regels voor milieuaansprakelijkheid.

4 Een verbetering van het vervoerssysteem en het bodemgebruik. Men denkt aan vervoersheffingen die leiden tot ook ecologisch verantwoorde prijzen, en investeringen in openbaar vervoer.

\subsubsection{BELEIDSPERSPECIEVEN OP NATIONAAL NIVEAU}

In 2000 publiceert het RIVM de Nationale milieuverkenning 2000-2030 (RIVM 200o). Dit rapport is de wettelijk verplichte wetenschappelijke bouwsteen voor het NMP IV. Op veel punten maakt het NMP overigens een eigen analyse. Het NMP IV is, aldus de regering, niet een normaal beleidsplan dat het NMP III vervangt (NMP IV 2001: 6). Tenzij uitdrukkelijk anders is aangegeven, blijft dit laatste NMP onverkort van kracht. Het NMP IV wil vooral iets extra's bieden: een agenderende visie voor de zeer lange termijn, tot 2030, en een accentuering van de wereldwijde dimensie van de huidige milieuproblemen. De nota over wetgeving Met recht verantwoordelijk (2001) werkt de juridische aspecten uit en betreft vooral de korte en middellange termijn. De nota is weliswaar een discussiestuk, maar gelet op de parlementaire instemming op hoofdlijnen biedt het stuk een zeker beleidskader.

\section{De aard van de problemen}

De prealabele vraag: hoe met onzekerheden om te gaan? In zijn perceptie van de aard van de problemen geeft het RIVM veel systematischer dan voorheen aandacht aan de factor onzekerheid. Zij wordt onderscheiden in twee typen: ten eerste variabiliteit, die haar bronnen heeft in de onvoorspelbaarheid van de natuur, menselijke, culturele, maatschappelijke en technologische ontwikkelingen; ten tweede gebrek aan kennis, die wordt bepaald door conflicterende informatie, onwetendheid en geringe mate van bepaaldheid en die mede wordt veroorzaakt door een gebrek aan betrouwbaarheid, ten gevolge van onnauwkeurige data, gebrek aan metingen en praktische onuitvoerbaarheid.

In een document Uncertainty and rivm environmental outlooks (RIVM 2001a) is dit thema nader geproblematiseerd. Hier komt naar voren dat binnen het RIVM sprake is van een eerste fase van een bewustwordings- en leerproces, waarin het probleem wordt onderkend, en op onderdelen in het rapport er ook rekening mee wordt gehouden. Deskundigen van het RIVM maken duidelijk dat het niet alleen een leeren omschakelingsproces van het onderzoeksinstituut zelf betreft; de maatschappelijke en beleidsomgeving hebben nog sterk positivistische verwachtingen van de wetenschap: wetenschap moet zoveel mogelijk onzekerheid reduceren. 
Typologie van problemen

Waar het RIVM het hoofdonderscheid formuleert in termen van opgeloste en niet-opgeloste, hardnekkige problemen, maakt het NMP een primaire scheiding tussen binnen het bestaande beleid al of niet beheersbare problemen.

Als beheersbare problemen worden in het NMP IV met name genoemd: verontreiniging van oppervlaktewater, lucht en bodem, behandeling van bepaalde afvalstoffen, bestrijdingsmiddelen, geluidshinder, kernenergie en ioniserende straling, en de uitstoot van een deel van de meest gevaarlijke, prioritaire stoffen. Onder beheersbare problemen vallen ook die welke nog niet de omslag hebben gemaakt van sanering naar preventie en beheer maar waar de sanering een kwestie van tijd is, zoals de bodembescherming. Beheersbaarheid hoeft evenmin uit te sluiten dat we nog jaren de naijleffecten van milieuverontreiniging uit het verleden zullen ondervinden, zoals bij de overbemesting.

Het zal steeds een opgave zijn om te verhinderen dat de milieuwinst teniet wordt gedaan door volumegroei, maar bij dit type problemen lijkt dit gezien recente ervaringen mogelijk. In ieder geval staan vragen van beleidsuitvoering hier centraal.

\section{Hardnekkige problemen die toekomstgerichte beleidsontwikkeling vragen volgens het NMP IV}

Het NMP IV noemt een zevental grote milieuproblemen voor de toekomst:

1 biodiversiteit,

2 klimaatverandering,

3 overexploitatie van natuurlijke bronnen enerzijds; en

4 bedreigingen van de gezondheid,

5 van de externe veiligheid,

6 aantasting van de leefomgeving, en

7 mogelijk onbeheersbare risico's anderzijds.

Dit laatste probleem wordt als volgt verduidelijkt. De geschiedenis leert dat oplossingen voor vandaag de problemen van morgen kunnen zijn en dat de negatieve bijeffecten in de vorm van nieuwe risico's zich pas later manifesteren. De geglobaliseerde wereld geeft echter een geheel nieuwe context, waardoor nationale overheden minder greep hebben op mogelijke risico's van nieuwe technologieën als robots, nanotechnologie en genetica. Dit kan ertoe leiden dat de milieuvervuiling van de 21ste eeuw vooral een biologische vervuiling zal zijn, bepaald door ongewenste, maar zich snel verplaatsende en zich aanpassende virussen, bacteriën, insecten en ontsnapte nanorobots. Juist dit soort gevaren is slechter te bestrijden dan klassieke vormen van milieuvervuiling als zware metalen.

Het verschil tussen de eerste drie en de vier overige problemen ligt in het NMP vooral in de aard van de noodzakelijke remedie. Bij de eerste problemen kan niet met beleidsvernieuwing op zich worden volstaan; een meer fundamentele 
aanpak is nodig, het zogenoemde 'transitiemanagement'.

Voor deze zeven problemen worden enige barrières genoemd die een oplossing in de weg staan:

1 structureel: de ongelijke welvaartsverdeling in de wereld en de grote onzekerheden bij systeeminnovaties;

2 instrumenteel: het denken op korte termijn; tekorten in het instrumentarium; het feit dat probleemveroorzakers niet de oplossers zijn; gebrek aan voorzorg;

3 institutioneel: gebrek aan afstemming tussen sectoren en tussen bestuurslagen, nationaal en internationaal.

De SER (2001: 21) noemt in dit verband als lacune de taaiheid van consumptiepatronen. De VROM-raad wijst op de (on)voldoende wil om beleidsmatig op uitvoeringsniveau in duurzame ontwikkeling te investeren; ook deze raad vraagt meer aandacht voor de sociale koppeling tussen milieubeleid en de maatschappelijke praktijk (VROM-raad 20orb: 21).

\section{Beoogd beleid en bestuur}

Algemeen ambitieniveau, beginselen en beleidsaanpak

Het NMP geeft de volgende omschrijving van de beleidsambitie: een bijdrage leveren aan een gezond en veilig leven, in een aantrekkelijke leefomgeving, te midden van een vitale natuur, zonder de mondiale diversiteit aan te tasten dan wel natuurlijke hulpbronnen uit te putten, hier en nu, elders en later. Leidende beginselen dienen hier te zijn: duurzaamheid in ecologische, sociale en economische zin, het preventie- en voorzorgsbeginsel. Daarnaast blijven de beginselen van oudere datum, zoals bestrijding aan de bron, de vervuiler betaalt, het alarabeginsel en externe integratie onverkort gelden. Deze inhoudelijke beginselen vragen een codificatie in ook de Nederlandse wetgeving. Zij worden in dit NMP gepresenteerd als een antwoord op de geconstateerde barrières (NMP IV 2001: 65).

De gewenste beleidsaanpak kenmerkt zich door:

1 een integrale afweging van ecologische, sociale en economische kosten en baten op korte en lange termijn;

2 een gedifferentieerde en beredeneerde keuze van de juiste bestuurlijke schaal, hetzij nationaal, hetzij boven- of subnationaal;

3 een goede doorvertaling van het ambitieniveau in achtereenvolgens richtinggevende doelen, afrekenbare doelen en ten slotte concrete taakstellingen voor de maatschappelijke actoren;

4 internalisering van de milieuschaarste en -kosten (NMP IV 2001: 19).

\section{Bestuurlijke uitwerking}

Er is behoefte aan een krachtige overheid die meerdere functies vervult: schakelen (partijen bij elkaar brengen), stimuleren, het scheppen van de juiste omstandigheden en sturing en handhaving. Waar het gaat om bedreigingen, die onom- 
keerbare gevolgen kunnen hebben voor mens en milieu, is een strakke overheidsregulering nodig.

In de instrumentele sfeer zijn er enkele duidelijke verschuivingen:

1 een positieve herwaardering van het verticale instrument van algemene ge- en verbodsbepalingen, in het bijzonder waar het gaat om veiligheids- en gezondheidsbelangen (NMP IV 2001: 72);

2 een voorgenomen kritische evaluatie van de effectiviteit van convenanten;

3 uitbreiding van het arsenaal van marktconforme instrumenten met een systeem van verhandelbare emissies.

\section{Transitiemanagement}

Als specifieke beleidsaanpak voor de drie grootste problemen pleit het NMP voor transitiemanagement. Transitiemanagement houdt in dat technologische, economische, sociaal-culturele en institutionele veranderingen tot stand moeten komen en vervolgens op elkaar moeten inwerken en elkaar moeten versterken (NMP IV 2001: 74-75). Het is een zaak van de gehele samenleving, al heeft de overheid wel een voortrekkers- en regierol. Het model vraagt een op het proces gerichte sturing, waarin onzekerheid, complexiteit en samenhang kernbegrippen zijn.

De SER en de VROM-raad zijn beide positief over het idee, maar hebben over de uitwerking nog vele vragen. Met het doelgericht aansturen van een transitie met een zo algemeen doel als duurzaamheid is nog weinig ervaring opgedaan. Eerdere transities in de vorige eeuw, zoals de aanleg van een drinkwaternet, hadden een concreet doel en konden wel binnen de nationale context worden gerealiseerd. Die gunstige randvoorwaarden ontbreken. Het zal een zware opgave zijn om de essentiële elementen van de beoogde transitie tegelijkertijd te verwezenlijken. De volgende wezenlijke elementen worden in dit verband genoemd:

1 fundamentele, ook institutionele vernieuwing;

2 vasthouden aan het doel op langere termijn;

3 samenwerking met andere overheden en maatschappelijke actoren.

Verder zijn er, ook internationaal gezien, grote kennislacunes in het beleid (SER 2001: 26 e.v.).

\section{Parlementair beraad}

De beraadslagingen in het parlement over de nota Met recht verantwoordelijk (2001) leidt tot consensus op een aantal belangrijke punten, zoals het internationale recht als uitgangspunt voor Nederlands recht, de eigen unieke verantwoordelijkheid van de overheid met betrekking tot het algemeen milieubelang (de eigen afweging die de overheid moet maken tussen risico en maatschappelijk nut), de codificatie van inhoudelijke rechtsbeginselen, en de eis van hanteerbare en handhaafbare wetgeving. Binnen dit kader moeten globalisering, vereenvoudiging van overheidsregels en zelfregulering hun beslag krijgen. Concrete uitwerkingen zijn de vergunning op hoofdlijnen en een zekere voorkeur voor doelvoor- 
schriften. Eisen van goede wetgeving kunnen soms op middelen gerichte voorschriften wenselijk maken, zo kwam algemeen naar voren.

Meer ambivalent is de ontvangst van het NMP IV: enerzijds heeft de Tweede Kamer waardering voor het in de laatste jaren wat verwaarloosde visionaire element, anderzijds is er veel kritiek op de te geringe bestuurlijke en vooral financiële uitwerking. Ook de voorgestelde herschikking in de relatie tussen verticale en horizontale instrumenten, zoals convenanten, wordt vooral door de VVD en het CDA gezien als een stap terug op de succesvolle Nederlandse weg van participatie en interactieve beleidsvorming. Het beraad spitst zich sterk toe op de 'minder grote' milieuproblemen, zoals de bedreiging van de gezondheid, de veiligheid en de aantasting van de leefomgeving. Eerder had de VROM-raad voor deze ontwikkeling gewaarschuwd (VROM-raad 2001).

\section{De kennisorganisatie, met name het RIVM}

In mei 2001 heeft de regering een voorstel ingediend voor een op onderdelen ingrijpende reorganisatie van het RIVM, dat inmiddels door het parlement is geaccordeerd. De regering ziet geen aanleiding om de activiteiten van het RIVM te 'vermarkten', door middel van een stelsel van concessies en aanbestedingen. Tegen deze vorm van concurrentie om de markt verzet zich haar inziens een aantal overwegingen:

1 het beleidsnabije, beleidsondersteunende karakter van de activiteiten, vooral de planbureaufunctie;

2 het gegeven dat het RIVM alleen voor de overheid werkt en zeker de planbureaufunctie een wettelijke overheidstaak is;

3 het feit dat de kwaliteit van het onderzoek vaak niet zodanig is te specificeren dat een betere uitvoering getoetst en contractueel kan worden gegarandeerd.

De beleidsnabijheid vergt voor het RIVM de juridische status van agentschap, waarbij de ministeriële verantwoordelijkheid intact blijft; in wetgeving (zie subpar. 2.3.4) en protocollen is de onafhankelijkheid van het instituut al voldoende gegarandeerd. Om deze laatste reden wordt de status van een zво afgewezen. Wel vraagt de ministeriële aansturing om herziening. Deze herziening heeft de volgende componenten:

a Er moet sprake zijn van een duidelijke procedurele en structurele scheiding tussen twee naar hun aard verschillende rollen van de aansturende overheid ten opzichte van het instituut, te weten die van eigenaar en inhoudelijke opdrachtgever. Bij de rol van eigenaar gaat het om de overheidsverantwoordelijkheid voor de existentie, missie en algemene strategie van het RIVM. Deze rol kan in strijd komen met de opdrachtgevende rol, de inhoudelijke aansturing. De overheid wil als eigenaar de continuïteit van het instituut vooropstellen, als opdrachtgever wil zij eerder een maximaal resultaat bereiken tegen zo min mogelijk kosten.

b De opdrachtrelatie moet een meer resultaatgericht karakter krijgen. Hiertoe moeten bij de inhoudelijke aansturing langjarige afspraken op een meer abstract niveau over taakvervulling en financiering het kader bieden voor jaar- 
lijkse, meer operationele afspraken over de kwaliteit, tijdigheid, kosten en verantwoording van individuele projecten. Bovendien moet de opdrachtgever zijn kennisvragen beter expliciteren. De inhoud van de afspraken moet niet zozeer verschillen naar ministerie als naar de aard van de opgedragen activiteiten: wettelijke taken als planbureaufuncties, die het RIVM meer autonoom uitvoert, meer permanente en meer incidentele opdrachten.

\subsubsection{CONCLUSIES}

Bij de perceptie van de aard van de problemen valt allereerst op dat het milieubeleid in zekere zin terug bij af is: volksgezondheidsaspecten worden weer expliciet onder het milieubeleid begrepen. Hetzelfde geldt voor veiligheid. Dit heeft uiteraard mede te maken met de recente maatschappelijke commotie op dit terrein. Dit maakt weer eens duidelijk hoezeer de perceptie en categorisering van problemen geen zaak zijn van objectieve vaststelling, maar dat zij sterk contextueel en beleidsmatig zijn bepaald. Relevant is verder dat de oeso oog heeft voor een aparte categorie problemen, welke met veel onzekerheden zijn omgeven, en dat ook het RIVM deze problematiek onderkent, maar dat het NMP iv bij de nietopgeloste problemen de onzekerheden vooral beperkt tot de remedie.

Beleidsmatig zijn uiteraard de drie beleidsperspectieven van de OESO, de EU en Nederland maar in beperkte mate vergelijkbaar. Zij verschillen sterk van karakter. Het NMP IV heeft duidelijk de hoogste ambitie, als visionair stuk voor de langere termijn. Op EU-niveau krijgt nu ook het facet-karakter van milieubeleid duidelijk gestalte.

Bestuurlijk zijn op nationaal niveau vooral de keuze voor een relatief nieuw beleidsmodel en een positieve herwaardering van het verticale instrument markant.

Op kennisterrein wordt het beleidsondersteunend karakter van het RIVM jegens de overheid verduidelijkt en versterkt. 


\subsection{ALGEMENE CONCLUSIES: VRAGEN EN AANDACHTSPUNTEN VOOR DE TOEKOMST}

\subsubsection{DE AARD VAN DE PROBLEMEN}

\section{Beheersbare problemen}

In alle recente beleidsstukken wordt de categorie van beheersbare problemen uitdrukkelijk onderkend. De beleidsopgave is duidelijk: de bereikte milieuwinst vasthouden en versterken. De beleidsvragen betreffen vooral de middelen: hoe te komen tot een meer doelmatig en doeltreffend beheer?

Een van de toekomstvragen hierbij betreft de rol van informatie- en communicatietechnologie (ICT). ICT kan leiden tot efficiency-winst; het beginsel van de vervuiler betaalt en de daarop gebaseerde heffingen kunnen gerichter worden ingezet. Het toezicht op de naleving kan door een meer gedetailleerde en realistische monitoring worden verbeterd en informatieve instrumenten, zoals effectrapportage, verslaglegging en etikettering kunnen aan waarde winnen. Daarnaast kan ICT in de vorm van deterritorialisering ook het tekort in de handhaving versterken.

\section{Overige problemen}

Waar in de nationale documenten de hardnekkige en nieuwe problemen onder een categorie worden geplaatst, maakt het OESO-document een nadere tweedeling: het onderscheidt potentiële problemen die zijn omgeven met veel onzekerheid, zoals de problematiek van gevaarlijke stoffen, en hardnekkige urgente problemen, zoals de afnemende biodiversiteit. De eerste vergen een oranje, de tweede een rood licht.

Vooral conceptueel lijkt deze nadere differentiatie een verrijking. Bij de hardnekkige, urgente problemen zijn de aard van het probleem en de beoogde eindsituatie relatief duidelijk. De moeilijkheden betreffen vooral de te beperkte doeltreffendheid van de beleidsinspanning. Bij de oranje categorie van problemen, omgeven met veel onzekerheid, zijn de beleidsvragen veel principiëler. Er is onzekerheid over de aard van het probleem, die vervolgens doorwerkt op het niveau van de legitimatie van beleid. De vraag is dan: moet er gegeven die onzekerheid überhaupt wel opgetreden worden? Deze legitimatievraag wordt nog versterkt wanneer, gezien de aard van het potentiële probleem, bij eventueel beleidsmatig optreden ingrijpende maatregelen voor de burger en het bedrijfsleven nodig zijn. De voor hen hoge kosten van beleid kunnen niet worden gerelateerd aan duidelijk vaststelbare baten die deze kosten rechtvaardigen. Daarnaast is de rol van de wetenschap bij de beleidsvorming bij de oranje categorie van problemen veel complexer. De wetenschap moet erkennen dat haar inbreng beperkingen heeft en de overheid kan geen alomvattend beroep doen op de wetenschap ter legitimatie van het beleid. 
Al met al zijn er goede redenen om met de oEso de nog niet opgeloste en nieuwe problemen niet onder een categorie onder te brengen, maar uitdrukkelijk een nadere differentiatie te maken tussen problemen die zijn omgeven met veel onzekerheden en overige hardnekkige, nog niet beheersbaar gemaakte problemen. Een aantal al genoemde kenmerken van de nog niet opgeloste en nieuwe problemen leidt er immers toe dat hier vaak ernstigere vormen van onzekerheid aanwezig zijn. De territoriale schaal is in hoge mate bovennationaal; er is sprake van langere tijdsketens; de ontwikkelingen zijn sluipend; er is sprake van een veelvoud van bronnen; en de mate van directe kenbaarheid en voelbaarheid van milieuschade en van de causale relaties zijn beperkt voor hen die geen expert zijn. Er is een dominante rol van wetenschappers, die in hun laboratoriumonderzoek en bij het opstellen van modellen uit moeten gaan van bepaalde, overeengekomen uitgangspunten en aannames die voor derden niet altijd kenbaar zijn. Bovendien zijn veel van deze milieuproblemen vaak slechts binnen een laboratoriumsituatie traceerbaar; men denke aan de gevolgen voor het milieu van het geheel van honderden gevaarlijke stoffen in hun onderlinge combinatie.

Er is derhalve sprake van een complexe problematiek die vanuit verschillende optieken en ermede verbonden hiërarchieën van waarden, kan worden gediagnosticeerd. De gewenste oplossing roept een sterk belangenconflict op en heeft bovendien een zware gedrags- en institutionele component. Veelal gaat het immers om een structurele wijziging van reguliere consumptie- en productiepatronen. Met name het NMP III gaat op dit laatste aspect uitvoerig in.

Bij dit legitimatieprobleem speelt de wetenschap een cruciale rol. De gewenste oplossing vraagt een zware legitimatie, gegeven het ingrijpende karakter van de mogelijke overheidsinterventie. Gezien de beperkte kenbaarheid van het probleem wordt juist hier op de wetenschap een bijzonder beroep gedaan, welke verwachting de wetenschap om dezelfde reden lang niet altijd kan leveren. Bekkers en Verschuuren (1998) spreken in dit verband van de opkomst van ongetemde, 'wicked' problemen. Een eenduidige probleemdefinitie en -oplossing ontbreken. Er is onvoldoende informatie en kennis om de kosten en baten te specificeren; bovendien ontbreken adequate beoordelingscriteria om een goede afweging tussen beide te maken. Het zijn juist dit type problemen die onder de eerder beschreven oranje categorie vallen.

\section{De problemen omgeven met veel onzekerheden en het voorzorgsbeginsel}

Het in de jaren tachtig vanuit de bestuurlijke en juridische praktijk opgekomen voorzorgsbeginsel heeft betrekking op de oranje categorie van problemen die zijn omgeven met veel onzekerheid. Het voorzorgsbeginsel houdt in dat het ontbreken van wetenschappelijk bewijs geen reden mag zijn om niet in actie te komen tegen mogelijke bedreigingen die een ernstig of onomkeerbaar karakter hebben (NMP IV 2001: 65). Het voorzorgsbeginsel is bij uitstek bedoeld voor situaties waarin de aanwezige kennis nog niet volledig is, maar waarin er wel een gerechtvaardigde indicatie is dat er een verband is tussen een bepaalde handeling en mogelijke nadelige effecten. Ook blijkens internationale jurisprudentie kan dit 
beginsel alleen van toepassing zijn bij een geconstateerde partiële kennis (Lambers 200o: 179). McIntyre en Mosedale (1997) zien de historische oorsprong van dit beginsel ook tegen de achtergrond van de noodzaak om bestuurlijke beslissingen te nemen in situaties waarin de wetenschap juist niet komende milieudreigingen kan vaststellen en goede oplossingen kan aandragen.

Dat het voorzorgsbeginsel voor dit type problemen geen panacee is, moge duidelijk zijn. Allereerst is er een conceptuele onduidelijkheid: ook in het NMP IV krijgt dit beginsel zeer verschillende definities (VROM-raad 2001b: 25). Ten tweede is er de meerduidigheid van het criterium van een vermoeden van ernstige, onomkeerbare gevolgen voor het milieu, als maatstaf om het beginsel überhaupt van toepassing te verklaren. Zo geven verschillende normatieve opvattingen over de robuustheid van de natuur aanleiding tot volstrekt andere worst case scenarios (VROM-raad 20orb: 27). Is het beginsel van toepassing, dan is wel duidelijk dat een risicovaststelling en een risicoweging moeten plaatsvinden, maar de inhoudelijke uitkomst van de weging staat niet vast, daar die wordt bepaald door eveneens meerduidige beginselen als redelijkheid, zorgvuldigheid en proportionaliteit. Ook het WTO-beginsel van non-discriminatie in de buitenlandse handel kan in dit verband worden genoemd. Verder speelt de complicatie dat juist in een situatie waarin het beginsel van toepassing is, een rationele afweging vooraf van maatschappelijke kosten en vooral van de baten ook technisch erg moeilijk is (VROM-raad 2001: 27).

In die situatie is het begrijpelijk dat zich recentelijk in Nederland een discussie heeft ontwikkeld over het nut van het voorzorgsbeginsel. Het beginsel zou haaks staan op het rationele risicodenken, dat de basis is voor de vooruitgang in de westerse wereld en bovendien is het beginsel dubbelzinnig, hetgeen kan leiden tot eenzijdige simplistische toepassing ervan (Pieterman 2001, reactie Drupsteen 2001).

Voor een evenwichtige bepaling van de waarde van het beginsel vraagt evenwel ook de andere kant van de medaille aandacht. Allereerst bieden beginselen nog geen oplossing; beginselen geleiden meer het zoeken van een oplossingsrichting. Bovendien bevordert het beginsel dat moeilijke vragen en dissensus expliciet gemaakt worden. Het beginsel geeft ook een eigen impuls aan wetenschappelijk onderzoek. Ten slotte is een discussie op zuiver nationaal niveau weinig zinvol, gezien de algemene internationale erkenning van dit beginsel als internationaal gewoonterecht (zie voor beide aspecten McIntyre en Mosdale 1997).

\subsubsection{BELEID EN BESTUUR}

\section{Ontwikkelingen op schaalniveau}

Er is sprake van een ontwikkeling in meerdere richtingen. Er is een toenemende bestuurlijke decentralisatie naar het lokale, regionale niveau. Daarbij gaat het vooral om het beheer van het milieu, teneinde inpassing in een breder omgevingsbeleid, differentiatie en maatwerk mogelijk te maken. Kortom, de eerdergenoemde 'groene' problemen. 
Voor de nationale overheid is de belangrijkste contextuele factor de steeds dominantere rol van de EU op milieuterrein. Reeds nu wordt rond 70 procent van de normering op dit niveau vastgesteld (zie subpar. 2.4.4). Minstens zo relevant is dat de EU in toenemende mate ook de beleids- en juridische structuur op nationaal niveau bepaalt, in termen van het begrippenapparaat, de te hanteren beginselen en de instrumentenkeuze. Op het punt van wetenschappelijke legitimatie van de nationale differentiatie van Europees beleid stelt de EU bovendien extra hoge eisen.

Dit proces verandert allereerst het karakter van het internationale beleid van de rijksoverheid. Kon in de vroegere fase van de internationale bewustwording, vanaf de jaren tachtig, Nederland zich in hoge mate beperken tot initiërend beleid, nu krijgen andere aspecten een zwaarder gewicht. Het accent komt te liggen op de nationale beïnvloeding van het voorgenomen EU-beleid, opdat het toepasbaar is binnen de specifieke Nederlandse situatie, en op de verantwoordelijkheid voor een adequate uitvoering van internationale verplichtingen, ook door decentrale overheden. Een mogelijke voortrekkersrol van Nederland op internationaal niveau is nu niet meer alleen een zaak van het uitdragen van ideeën. Men is slechts geloofwaardig als men zelf aan de vastgelegde verplichtingen voldoet.

Deze verplaatsing van de beleidsontwikkeling naar het bovennationale niveau geldt ook voor de problematiek van het omgaan met potentiële milieurisico's. De spanningen die deze problematiek op zich al oproept, worden ten gevolge van de bestuurlijke schaalvergroting versterkt. Dit geldt vooral voor de maatschappelijke legitimatie. De burger zal de nationale overheid blijven aanspreken op de acceptatie van bovennationaal geformuleerd beleid. De fora waarbinnen het maatschappelijke debat plaatsvindt, blijven in hoge mate nationaal en hebben maar een beperkte mate een equivalent op Europees niveau.

\section{De maatschappelijke acceptatie van milieubeleid}

Ook in een ander opzicht zal de maatschappelijke aanvaarding van beleid bij dit type beleidsproblemen, de potentiële milieurisico's, moeilijker worden. Kritische, hoogopgeleide burgers zijn beter in staat wetenschappelijke onzekerheden te onderkennen. Ten tweede zal een beperkt wetenschappelijk te legitimeren beleid extra weerstanden oproepen bij de burger. De maatregelen zijn voor hem immers ingrijpend, denk bijvoorbeeld aan de structurele doorbreking van bestaande consumptiepatronen. Deze maatregelen vragen offers van de consument in termen van geld, tijd, gemak en status, zonder dat hem zekerheid kan worden gegeven over de beloning, de door hem zelf ervaren milieuwinst. De al lang onderkende problematiek dat instemming van de burger met het milieubeleid op macroniveau niet zonder meer doorwerkt op zijn medewerking als consument op microniveau, wordt hierdoor versterkt.

\section{Ontgrenzing van het milieubeleid}

Deze tendens wordt allereerst gestimuleerd door de introductie van het verbrede 
beginsel van duurzame ontwikkeling als algemene pijler voor nationaal en Europees beleid. In zijn rapport Duurzame ontwikkeling (WRR 2002b: 55 e.v.) heeft de WRR op de nadelen van deze verbreding gewezen. Een tweede ontgrenzing geeft het ook algemeen aanvaarde beginsel van externe integratie: in het gehele beleid moeten milieueisen als facet worden gehonoreerd. Dit is de ene richting van de samenhang. Versterking van economische, marktconforme instrumenten in het milieubeleid impliceert ook dat het economische beleid zijn eisen stelt aan het milieubeleid. Deze ontgrenzing van het milieubeleid werkt eveneens complicerend.

\section{Ontwikkelingen van horizontale sturing, het multi-actormodel}

Sinds de jaren tachtig is er een duidelijke tendens in de richting van meer horizontale sturing. Het recente overheidsbeleid, met name het NMP IV, plaatst hier kritische vragen bij. In bredere wetenschappelijke en maatschappelijke kring wordt echter juist gepleit voor een verdere versterking van dit type sturing, met name in de vorm van het zogenoemde 'multi-actormodel', als meest gerede antwoord op de aard van de huidige, met onzekerheden omgeven milieuproblemen (Bekkers en Verschuuren 1998; Weggenman en De Jong 2000).

Uitgangspunt in dit model is de institutionele erkenning van conceptuele en doelonzekerheid, gegeven de legitieme pluriformiteit van waarden en belangen van de verschillende betrokkenen. Vooraf gestelde monopolieposities, ook die van de overheid, worden afgewezen. In een open communicatie- en onderhandelingsproces van gelijkwaardige actoren wordt getracht primair op dit conceptuele en doelniveau tot overeenstemming te komen. Twee varianten zijn denkbaar: een strakke, vooraf en algemeen gestelde organisatievorm, zoals die van de ser, en een meer ad hoc gekozen, flexibele organisatievorm, gegeven de specifieke aard van het probleem. Bij de thans gaande experimenten, zoals bij het stedelijk milieubeleid, heeft de regering uitdrukkelijk gekozen voor de laatste variant.

De inhoudelijke ratio van dit nieuwe model - toenemende onzekerheid vergt een proces van gelijkwaardig en wederzijds conceptueel leren - roept evenwel in haar formele uitwerking principiële spanningen op. Het model raakt aan de wortels van het traditionele staatsbestel en met name aan de institutionele garanties van de waarden die hier in het geding zijn. In dit traditionele bestel zijn, gegeven de principes van machtenscheiding en legaliteit, de ongelijkwaardige bevoegdheden van actoren binnen en buiten de overheid juist wel vooraf wettelijk gefixeerd. De centrale rol van het parlement bij de beleidsbepaling en -verantwoording is gegarandeerd en hetzelfde geldt voor zaken als openbaarheid van bestuur, inspraak en rechtsbescherming. De uitwerking van het multi-actormodel is derhalve meer dan een operationeel, technisch probleem: zij zet bepaalde institutionele garanties op de tocht, zonder meteen goede alternatieven te geven.

De volgende vragen kunnen worden gesteld: moet de overheid als wetgever bij dit multi-actormodel niet toch bepaalde procedurele eisen vooraf vastleggen, vooral voor relatief zwak georganiseerde belangen; moet vooraf niet ook een 
aantal inhoudelijke (milieu)beginselen worden vastgelegd; en hoever reikt de regisserende, sturende rol van de overheid in het proces van onderhandelingen zelf, met het oog op de noodzakelijke consensusvorming? Ten dele wordt dit probleem opgelost doordat overheidskaderstelling vooraf en het gewenste open leer- en onderhandelingsproces elkaar niet zonder meer uitsluiten. De combinatie van procedurele en inhoudelijke kaderstelling kan het onderhandelingsproces eerder faciliteren dan frustreren. Wanneer bijvoorbeeld vooraf inhoudelijke beginselen worden aangegeven, zoals de mogelijkheid van compensatie, kan deze constructie het onderhandelingsproces vergemakkelijken. Op belangrijke punten zoals de rol van het parlement en de rechtsbescherming blijft het evenwel de vraag of er adequate vervangingsmechanismen zijn te construeren, of dat een zeker verlies aan institutionele garanties als prijs onvermijdbaar is.

Ten slotte kunnen nog enkele andere kritische kanttekeningen worden geplaatst. Het model gaat uit van bepaalde culturele vooronderstellingen. Het veronderstelt niet alleen de erkenning van pluriformiteit, maar op een basaal niveau ook een bepaalde consensus vooraf: de wil om eigen belangen en waarden te relativeren en de onderkenning van voldoende gemeenschappelijkheid en vertrouwen om het proces van wederzijds leren en compromisvorming aan te gaan. Pour discuter il faut être d'accord. Is die basale consensus er niet, dan liggen meer traditionele vormen van geschillenbeslechting voor de hand. Ten tweede: de eerdergenoemde problemen van schaalvergroting en maatschappelijke acceptatie worden als zodanig niet met dit model opgelost. Afgezien van de organisatorische complexiteit van multi-actorconstructies op Europees niveau, kunnen de beleids- en culturele tradities van andere landen zich hiertegen verzetten. Bij een zware institutionalisering van dit model is er bovendien het risico van gesloten netwerken, waarbij alleen de goed en sterk georganiseerde belangen als actor worden erkend en het leervermogen wordt verkleind. Bij een ruime toelating van het aantal actoren vergt de organisatorische complexiteit weer hoge bestuurskosten.

Al met al kan worden gezegd dat het multi-actormodel duidelijke voordelen biedt om het type probleem van potentiële milieurisico's te hanteren, maar vanuit vooral de staatsrechtelijke optiek ook weer problemen geeft en derhalve geen panacee is.

\section{De toekomst van het huidige planstelsel}

Vanaf het begin van de jaren tachtig staat in de milieusector het vraagstuk van de interne integratie van plannen centraal, in het bijzonder de integratie van milieuen ruimtelijke planning. Vanuit een toekomstperspectief kunnen wellicht andere, meer fundamentele vragen worden gesteld. De voor- en nadelen van dit planstelsel zijn juist omgekeerd, vergeleken met het multi-actormodel. Het huidige planstelsel past goed binnen ons staatsbestel. De overheid laat zich middels het RIVM informeren over te verwachten feitelijke ontwikkelingen en de politiek aanspreekbare overheid stelt plannen en programma's vast die deze feiten normatief wegen en in beleid vertalen. Het zwakke punt is hierbij dat het (bestuurlijk wenselijke) scherpe onderscheid tussen feiten en waardering onvol- 
doende recht doet aan de pluriformiteit van concepties waarbinnen de feiten worden gegoten, hetgeen juist het grote voordeel is van het model dat in de vorige subparagraaf is besproken.

Gegeven de juridische structuur en het feitelijk functioneren van planbureaus is er verder het risico dat deze constructie eerder leidt tot uniformering van concepties. De regering neemt analytische concepties die het RIVM hanteert, met name bij het NMP I, zonder meer over, waardoor wetenschappelijke modellen de status krijgen van beleidsmodellen. Ook de verplichte en feitelijke samenwerking tussen planbureaus geeft het risico dat men te gemakkelijk modellen van elkaar overneemt. Het risico van een inhoudelijke censuur door de minister ten aanzien van het werk van de planbureaus is door de wetgever uitdrukkelijk erkend. Het reële probleem ligt nu elders: in het samenspel tussen planbureaus onderling en met de departementen ontstaat er één gemeenschappelijke taal en modellering, die als enige beleidsrelevant worden geacht. Juist bij milieuproblemen, waar sprake is van een hoge mate van onzekerheid en waarbij de pluriformiteit van concepties per definitie een grote rol moet spelen, is dit risico van mogelijke uniformering van beleidsconcepties een reëel probleem.

\subsubsection{KENNISASPECTEN}

\section{De wetenschap als leverancier van feiten?}

Wetenschap en beleid hebben verschillende autonome waarden: het zoeken naar de waarheid en logische consistentie enerzijds en de ontwikkeling van consensus en het in evenwicht brengen van belangen anderzijds. Een natuurlijk spanningsveld is hiermede gegeven. Derhalve is keuzevraag aan de orde: welke betere en minder goede wegen zijn er om hiermee om te gaan?

Een weg die in de Nederlandse plantraditie heel duidelijk naar voren komt, is de levering door de wetenschap van feiten, die vervolgens in de modellering waarin zij wetenschappelijk worden gegoten, in het beleid worden overgenomen. Kortom, de wetenschappelijke dataverstrekking bepaalt de ruimte voor het beleid.

Het belang van goede informatie voor beleid kan moeilijk worden onderschat. De vraag is wel of, gezien de kwalitatieve problemen waar het milieubeleid de komende jaren voor staat, dit de kern van de wetenschappelijke kennisinbreng voor het beleid moet zijn. Wellicht moet in de toekomst het accent verschuiven naar andere vormen van kennisinbreng die traditioneel ook een taak zijn van de wetenschap, te weten het leveren van nieuwe ideeën, concepten en modellen.

Een nadeel van deze, nu dominante methode is bovendien dat het bij de beleidsvorming behorende maatschappelijke debat zich vaak niet uitstrekt tot de impliciete aannames die ten grondslag liggen aan de modellen waarbinnen de feiten worden aangeleverd. In het bijzonder wiskundige modellen geven de schijn van zuivere objectiviteit, welke schijn in de beleidsvorming oneigenlijk kan worden 
gebruikt. Wanneer reële vragen van pluriformiteit van aannames die tot verschillende modellen kunnen leiden, worden weggeredeneerd, tast dit het vertrouwen in beleid en wetenschap aan.

\section{Potentiële milieurisico's en kennisinbreng}

De klassieke vorm van kennisinbreng, te weten routinematige toegepaste wetenschap, is vooral functioneel indien er grote zekerheid is over de feitelijke en te verwachten situatie, over de optiek en over de te stellen doelen. Belangenconflicten en daarmee verbonden oriëntaties op waarden spelen hier een beperkte rol. De ondubbelzinnige diagnose biedt de mogelijkheid om de probleemoplossende expert een dito vraag voor te leggen en de oplossing aan hem te delegeren.

Milieuproblemen die hier centraal staan, voldoen in afnemende mate aan deze eis. Dit komt het beste tot uiting bij de hantering van het multi-actormodel, dat, zoals gezegd, ondanks alle eerder gesignaleerde uitwerkingsvragen op zich het beste voldoet aan de eigen kenmerken van vele, nu aan de orde zijnde 'oranje' problemen. Het type beleidsvorming en de hiervoor noodzakelijke kennisinbreng hebben hier gemeenschappelijke kenmerken. Waar de erkenning van pluriformiteit en horizontale consensusontwikkeling uitgangspunt zijn voor beleid, kan hier evenmin worden uitgegaan van een eenduidige kennisvraag. De opstelling van de onderzoeksagenda en het beleid zijn een zaak van onderhandelen, opdat de actoren zich hierin vanuit hun verschillende posities kunnen herkennen en zich hieraan uiteindelijk willen committeren.

Pluriformiteit in beleidsmatige positiebepaling heeft haar equivalent in de kennisontwikkeling. Zoals in dit model geen actor vooraf een monopoliepositie heeft in beleidsopzicht, zo is op kennisniveau (het idee van) vooraf gestelde, zekere en eenduidige kennis die bepaalde belangen en oriëntaties wegdefinieert, niet adequaat.

\section{Verschuivingen in andere kenmerken van de kennisinbreng}

In de manier waarop kennis wordt verzameld en aangewend verschilt het traditionele planmodel in verschillende opzichten van het multi-actormodel:

a De tijdsordening. Er is een belangrijk verschil in de tijdsorde tussen de traditionele planmatige beleidsontwikkeling en het interactieve multi-actormodel. Het planmodel kent een vrij rigoureuze scheiding in fasen en een daarbij passende taakverdeling tussen kennis en beleid. De wetenschap levert hier de feitelijke bouwstenen. Nadat deze haar 'zegje' heeft gedaan, is het woord aan het politieke beleid, dat deze feiten weegt, doelen en instrumenten formuleert en tot uitvoering overgaat. In het interactieve model is niet alleen de beleidsontwikkeling minder strak gestructureerd in fasen, hetzelfde geldt ook voor het proces van kennisontwikkeling. Iedere stap in de beleidsonderhandelingen heeft per definitie ook een kenniscomponent; actoren zullen elkaar steeds aanspreken op de mate van wetenschappelijke onderbouwing van hun positiebepaling. Er is een zekere verschuiving van de vroegere ontvlechting van kennisinbreng en beleidsontwikkeling naar vervlechting van beide processen. Vragen van 
'timing' van kennisinbreng en terugkoppeling tussen nieuwe beleidsmatige positiebepalingen en kennisinbreng zijn bij dit type beleid cruciaal. Een strenge tijdsordening is dan niet functioneel.

b Het aantal actoren. De kennisinbreng is in het model van meerdere actoren per definitie minder eenzijdig gerelateerd aan de overheid als unieke beleidsactor. Iedere actor zal in dit model wetenschappelijke kennis moeten kunnen gebruiken, als eigen pleitbezorger in het onderhandelingproces. De vraag of vanuit bepaalde normatieve beleidsaannames een zekere sturing uitgaat naar de modellering van informatievergaring, beperkt zich in het klassieke model vooral in de relatie tussen de overheid en haar planbureaus. In het model met meerdere actoren manifesteert zich deze vraag in een complexere context.

\section{Verbreding van het arsenaal van wetenschappen}

De sociaal-culturele dimensie van de milieuproblematiek is reeds lang onderkend: het gaat niet alleen om een natuurwetenschappelijk vast te stellen probleem, maar ook om het milieu(on)vriendelijk gedrag van mensen. In de toekomst zal daarnaast de institutionele component in de kennisinbreng versterking behoeven. De onzekerheid betreft immers niet alleen het natuurwetenschappelijk vast te stellen karakter van de mogelijke milieuschade, maar ook de institutionele vormgeving. De nieuwe ontwikkelen stellen eerder divergerende dan uniforme eisen aan de keuze van het beleidsmodel en de instrumenten. Deze disciplinaire verbreding vermindert verder de eenduidigheid van 'de' wetenschappelijke inbreng. Iedere discipline heeft zijn eigen oriëntatiekader.

Enkele voorbeelden kunnen dit verduidelijken. Vanuit milieuoogpunt wenselijke vormen van samenwerking tussen bedrijven kunnen in conflict komen met het beginsel van vrije concurrentie. Hetzelfde geldt voor overeenkomsten strekkende tot 'benchmarking' die bedrijven verplichten tot het openbaar maken van informatie. Ook bij het multi-actormodel is er, zoals gezegd, een duidelijke aansluitingsproblematiek tussen wat vanuit milieuoogpunt wenselijk is en de geldende juridische kaders.

\section{De rol van de wetenschapper}

In een beleidsmodel waarin meerdere actoren via onderhandelingen van pluriformiteit tot consensus willen komen, zal de wetenschapper in toenemende mate de rol krijgen van consultant voor bepaalde partijen en minder die van objectieve adviseur van de centrale beleidsactor in het planmodel. De pluriformiteit in wetenschappelijke inzichten die bij dit soort meerduidige problemen al aanwezig is, wordt door dit proces van selectief gebruik van kennis door de verschillende deelnemers versterkt. Dit roept een spanningsveld op. Gekleurde, selectief gekozen wetenschappelijke informatie is een normaal onderdeel van een onderhandelingsproces. Tegelijkertijd is een wetenschapper gehouden aan algemeen geldende professionele eisen. Juist bij vervlechting van beleids- en kennisontwikkeling kan deze dubbelrol zeer verwarrend werken en leiden tot vermenging van wetenschappelijke en beleidsverantwoordelijkheid. 
Een vergelijking met het werk van de juridische professional en consultant bij uitstek, de advocaat, kan deze problematiek verhelderen. Er zijn codes ontwikkeld die enerzijds de juridische professionaliteit van zijn advisering waarborgen, terwijl anderzijds volstrekt duidelijk is dat hij selectief argumenteert, gegeven de belangen van zijn cliënt. Gekleurde informatie en kennisinbreng zijn in die situatie geen probleem, omdat die kleuring als zodanig door anderen kan worden onderkend en gewogen.

De nieuwe consultancyrol van de wetenschapper vraagt derhalve enerzijds om versterkte kwaliteitsborging, anderzijds om codes die transparant maken welke aannames de kennisinbreng bepalen.

Uit het voorgaande vloeien de volgende vragen en eisen voort ten aanzien van de organisatie van kennis op het specifieke milieuterrein:

1 De gewenste organisatie moet in hoge mate een afgeleide zijn van de aard van het gekozen besturingssysteem. Voor het milieuterrein betekent dit het volgende.

a Allereerst is er het punt van de bestuurlijke schaal. Decentralisatie van beleid vergt ook decentralisatie van de kennisinfrastructuur. Dit proces roept problemen op, met name het risico van versnippering. Een nog belangrijkere ontwikkeling in het milieubeleid is schaalvergroting, met name europeanisering. Deze schaalvergroting stelt extra hoge eisen aan de internationale representativiteit en kwaliteit van de Nederlandse kennisorganisatie.

b Het vraagstuk van de relatie tussen horizontale en verticale sturing is zeker ook in het milieubeleid een permanente issue, mede gezien de genoemde positieve herwaardering in het beleid van verticale sturing. Duidelijk is dat met name bij horizontale sturing en bij het multi-actormodel de noodzaak van gelijke toegankelijkheid voor alle, ook maatschappelijke, actoren tot kennis zich in verscherpte mate stelt. Juist bij de hier centraal staande groep van potentiële milieuproblemen betekent een kennisvoorsprong veelal ook een voorsprong in het kunnen beïnvloeden van beleid. Een gelijkwaardigheid van actoren in dit model moet zich ook vertalen in de kennisorganisatie. Deze openbaarheid van kennis is in het (inter)nationale milieubeleid nog te versnipperd geregeld (Klijnstra 200o).

Natuurlijk kan worden gewezen op de verruimde mogelijkheden die ICT geeft. ICT biedt evenwel ook nieuwe mogelijkheden voor afschermen en het zich privaat toe-eigenen van kennis. Minstens even belangrijk is hier een andere tendens, namelijk de toenemende commercialisering van de kennisproductie die dit proces van het gesloten houden van kennisstromen bevorderen. Het gaat hierbij niet alleen om zuivere private marktcommercialisering, maar ook om de beleidstendens om publieke instellingen te stimuleren zo bedrijfsmatig mogelijk te werken, waardoor eveneens de publieke toegankelijkheid van kennis kan worden beperkt. Op deze punten zal naar nieuwe evenwichten moeten worden gezocht.

2 Het streven naar objectiviteit en onafhankelijkheid zijn algemeen erkende onderdelen van de professionele codes van wetenschappers. Nog belangrijker 
zijn de feitelijke machts- en belangenstructuren, de institutionele omgeving waarbinnen zij werken, die in hoge mate bepalen of zij hiertoe inderdaad worden gestimuleerd. Het door wetenschappers kunnen en durven erkennen van de eigen beperkingen en van niet weg te nemen onzekerheden wordt niet alleen bepaald door de eigen wetenschappelijke attitude, maar vooral door deze institutionele omgeving.

3 Dit roept met name de vraag op van de juridische en vooral feitelijke, financiële onafhankelijkheid van de organisaties waarbinnen zij werken. Het probleem van ongewenste juridische of economische afhankelijkheid van kennisinstellingen speelt vooral wanneer de cruciale kennis alleen bij enkele, zeer gespecialiseerde instituten aanwezig is.

4 De vervlechting van kennis- en beleidsprocessen verzwaart het risico van oneigenlijke wetenschappelijk legitimatie. Juist deze vervlechting vraagt ook een zekere ontvlechting in die zin dat duidelijk moet zijn waar sprake is van een kennisvraag, dan wel een vraag van beleid en wie derhalve de gerede partij is om die vraag te beantwoorden.

5 De noodzaak van transparantie vereist dat niet alleen de gebezigde wetenschappelijke methoden, maar ook het kader van aannames, waarbinnen de wetenschappelijke inbreng haar betekenis heeft, extern helder en toetsbaar zijn.

6 Gegeven deze vervlechting wordt de noodzaak van professionele kwaliteitsborging versterkt. Ook de selectieve stellingname van een wetenschappelijke consultant moet houdbaar zijn binnen het wetenschappelijk forum.

7 Ten slotte zijn er vragen van organisatie. In hoeverre moet de overheid zelf nog een kennisorganisatie beheren, al of niet op afstand? In hoeverre zijn concurrentie om de markt en openbare aanbesteding een reëel alternatief, teneinde inner circle-gedrag te vermijden en de pluriformiteit in kennisinbreng te versterken? Juist bij het nieuwe type milieuproblemen is de pluriformiteit extra van belang. In haar recente beleidsvoorstellen (par. 5.3) heeft de regering uitdrukkelijk gekozen voor een eigen, beleidsnabij, onderzoekinstituut. De beoogde verheldering van de opdrachtrelatie ten opzichte van de minister versterkt de transparantie. 


\section{VOORWAARDEN VOOR EEN GOED MILIEUBELEID}

\section{$3.1 \quad$ INLEIDING}

\section{De ontwikkeling van het 'moderne' milieubeleid}

Zowel in Nederland als daarbuiten is de 'moderne' milieuproblematiek ${ }^{1}$ de afgelopen decennia een belangrijk onderwerp in het publieke debat geworden. Bij de meeste burgers en bedrijven is de aandacht voor het milieu gegroeid, soms tegen wil en dank. Ook zijn er tal van milieuorganisaties ontstaan. Bij deze toegenomen aandacht heeft de overheid een belangrijke rol gespeeld. Het milieubeleid van de overheid heeft zich dan ook in de loop van de tijd sterk uitgebreid. Binnen de overheidsorganisatie zijn er omvangrijke milieudiensten ontstaan. Het relatief jonge beleidsveld heeft zich ontwikkeld tot een omvangrijk, gevestigd beleid, dat soms diep ingrijpt in de economische en maatschappelijke verhoudingen.

Ook in de wetenschappelijke beleidsanalyse heeft het milieu zich inmiddels een vaste plaats verworven. De wetenschappelijke aandacht gaat onder andere uit naar de samenhang tussen milieubeleid en economisch beleid: wanneer staan die op gespannen voet en wanneer zijn er win-win-mogelijkheden? In economische analyses vormt het bestaan van externe effecten als regel de invalshoek: het handelen van actoren heeft negatieve effecten op andere actoren - nu en in de toekomst - zonder dat dit in het prijs- en marktmechanisme wordt verrekend. Zulke analyses onderzoeken tevens de beleidsmogelijkheden die er zijn om die externe effecten te internaliseren (bijvoorbeeld via regulerende heffingen).

Milieuproblemen hebben de volgende combinatie van kenmerken:

- Zij hebben betrekking op fundamentele waarden van mensen.

- Er is sprake van een langetermijnperspectief.

- Burgers, bedrijven en beleidsmakers zijn voor hun oordeelsvorming in hoge mate afhankelijk van wetenschappelijk expertise.

- Als regel zijn remedies nodig die maatschappelijk diep ingrijpen en gedragsveranderingen vergen.

Deze combinatie van kenmerken heeft het milieubeleid vanaf het begin controversieel gemaakt. Niettemin heeft dit beleid ertoe geleid dat verschillende problemen op het oog redelijk succesvol zijn aangepakt. In hoofdstuk 4 zal dit nog nader worden geïllustreerd. Dit geldt vooral voor de vraagstukken rond lucht- en waterkwaliteit, industriële emissies en enkele afvalstoffen. Hoewel zich rond deze problemen aanvankelijk ingrijpende conflicten hebben voorgedaan, is er uiteindelijk overeenstemming ontstaan tussen de betrokkenen - binnen en buiten de overheid - over de aard van de problemen en hun aanpak. Deze min of meer opgeloste beheersbare ('groene') problemen vergen de komende jaren vooral een voortgezette aandacht bij de uitvoering. 


\section{De 'wicked problems'}

Daarnaast zijn er twee nieuwe categorieën van problemen waarvoor dit (gematigd) positieve beeld niet geldt:

- de ('oranje') groep van potentiële problemen, die zijn omgeven met veel onzekerheden ten aanzien van oorzaken en mogelijke effecten, zoals geldt voor de meeste gevaarlijke stoffen, de milieu-implicaties van de biotechnologie en de sterke volumegroei in het gebruik van energie en mobiliteit;

- de ('rode') groep van problemen die hardnekkig en urgent zijn, waarbij wél betrekkelijke overeenstemming is over de mogelijke effecten, maar waarbij maatregelen onder meer wegens hun ingrijpende karakter moeilijk te nemen en te implementeren zijn. Het belangrijkste voorbeeld van deze groep is het broeikaseffect.

Deze twee typen problemen worden hier in het vervolg samengenomen als de wicked (moeilijke) milieuproblemen. Kenmerkend is dat zij:

- een grotere territoriale schaal hebben en als regel de landsgrenzen overstijgen;

- betrekking hebben op lange tijdsketens;

- het gevolg zijn van een veelvoud aan puntbronnen;

- schade veroorzaken die minder direct kenbaar en voelbaar is;

- een toenemend beroep doen op wetenschappelijke kennis;

- oplossingen vereisen die structurele veranderingen van patronen van consumptie en productie vergen.

\section{Maatschappelijke en bestuurlijke context}

De ernstige milieuproblemen vormen de belangrijkste uitdaging voor het milieubeleid in het komende decennium. Zij zullen moeten worden aangepakt in een veranderde maatschappelijke context waarin opvattingen over overheid en samenleving in het algemeen, en over beleidssturing in het bijzonder aan veranderende inzichten en fluctuerende opvattingen onderhevig zijn. De belangrijkste tendensen zijn de volgende:

- Maatschappelijke partijen zijn in toenemende mate in staat hun specifieke wensen te articuleren.

- Daardoor is er een toenemende interactiviteit ontstaan tussen bestuurlijke, economische en andere maatschappelijke actoren.

- Maatschappelijke actoren moeten ook een rol spelen in de operationele verantwoordelijkheid van beleidsuitvoering (aanvullend op de overheidsrol, want de overheid kan het niet alleen).

- Van de overheid wordt steeds indringender geëist dat maatschappelijke risico’s worden voorkomen.

- Tegelijkertijd neemt de weerstand toe tegen daarop gerichte maatregelen, omdat voor velen de noodzaak ervan onduidelijk is, of omdat zij er last of nadeel van ondervinden.

- Door de toenemende complexiteit van problemen moet het beleid meer en meer in onderlinge samenhang totstandkomen. 
Om in deze context tot succesvol beleid te komen, volstaat een louter traditionele (verticale) beleidsvorming niet, maar vindt er daarnaast vaker een 'horizontalisering' van het beleid plaats (Hazeu 2000a; 200ob; WRR 2002b). Het multi-actormodel is daar de moderne uitdrukking van (vroegere benamingen of associaties zijn: 'corporatisme', 'middenveld' of 'civil society'). Dit horizontaliseringsproces veroorzaakt uiteraard spanningen met de verticale top-down gerichte publieke structuur en haar juridische vormgeving.

Verder geldt voor de 'moeilijke' milieuproblemen dat een internationale aanpak noodzakelijk is. Dit vergt ook een terugkoppeling op nationaal niveau, hetgeen vraagt om een nationale overheid die die 'scharnierfunctie' kan en moet vervullen, met name in de richting van de EU. Zo zullen internationale afspraken om het milieubederf terug te dringen, moeten worden vertaald naar nationaal beleid. Terwijl de legitimiteit van het beleid in eerste instantie aan de internationale afspraken wordt ontleend, maakt het verdelingsvraagstuk - de pijn van het beleid - toch een verantwoording aan de nationale belanghebbenden nodig om tot beleidslegitimering te komen. De scharnierfunctie stelt ook de bottom-upproblematiek aan de orde, mede naar aanleiding van de verdere uitbreiding van de EU. Het gaat dan vooral om de vraag hoe (milieu)beleid democratische legitimiteit kan behouden of verwerven. $\mathrm{Zij}$ agendeert, met andere woorden, het vraagstuk hoe ‘burgers bij hun bestuur moeten kunnen' (vgl. Vaubel 2002).

\section{Hoofdstukindeling}

De ontwikkeling van de milieuproblematiek en van de maatschappelijke context waarin die problematiek moet worden aangepakt, leiden tot vragen over het milieubeleid van het komend decennium. Het wordt steeds moeilijker om beleid te vormen en uit te voeren dat kan rekenen op instemming van alle bij het milieubeleid betrokken actoren. Het 'laaghangende fruit' is inmiddels wel geplukt, en nu komen er steeds meer indringende keuzes aan de orde die niet binnen een winwin-bestek vallen (tenzij men een uitgesproken technologieoptimist is). Om dit te verduidelijken, gaat paragraaf 3.2 in op de vier voorwaarden waaraan een beleidsproces en beleidsproduct in het algemeen moeten voldoen: rechtmatigheid, doelmatigheid en doeltreffendheid, politieke haalbaarheid, en maatschappelijke aanvaardbaarheid. De verschillende voorwaarden kunnen aanleiding geven tot spanningen en dilemma's; daarop wordt ingegaan in paragraaf 3.3 .

De vier voorwaarden zijn niet louter 'passieve' toetsingscriteria, maar de overheid kan - en moet - ook actief werken aan het draagvlak voor beleid. In die gedachtegang spelen ten eerste kennis en informatie, en ten tweede participatie en interactie een belangrijke rol in de reguliere mechanismen van steunverwerving. Paragraaf 3.4 belicht de rol van deze twee stuwende krachten.

Paragraaf 3.5 vertaalt het kader van dit hoofdstuk naar een opzet voor een empirische analyse van praktijken van beleidsvorming op milieuterrein. Die slotparagraaf vormt de opmaat voor hoofdstuk 4 waarin hierop uitvoerig wordt ingegaan aan de hand van een aantal zorgvuldig geselecteerde casussen. 
Elk overheidsbeleid grijpt in in maatschappelijke ontwikkelingen. In de democratische rechtsstaat dient de overheid dit ingrijpen te kunnen verantwoorden. Die verantwoording kan worden gerelateerd aan de beoogde doelen van het beleid (juridisch rechtmatig en politiek haalbaar). Ook kan die verantwoording betrekking hebben op de mate waarin en de wijze waarop de beleidsdoelen (kunnen) worden gerealiseerd; het gaat dan om het onderscheid tussen enerzijds doeltreffendheid en doelmatigheid en anderzijds maatschappelijke aanvaardbaarheid. $\mathrm{Bij}$ het proces van verantwoording van beleid spelen dus verschillende voorwaarden impliciet of expliciet een rol. Beleid moet rechtmatig zijn, het moet doelmatig en doeltreffend zijn, het moet haalbaar zijn, en het moet aanvaardbaar zijn. Die voorwaarden zijn uitgewerkt in verschillende wetenschapsgebieden, met name recht, economie, politicologie/bestuurskunde en sociologie. We gaan eerst kort in op de conceptuele achtergrond van die criteria (subpar. 3.2.1), om ze daarna een voor een uitvoeriger te behandelen (subpar. 3.2.2 t/m 3.2.5).

\subsubsection{LEGITIMATIEBRONNEN EN HANDELINGSLOGICA VAN BELEID}

Bij het vaststellen van de criteria om beleid te beoordelen, gaat het om de vraag waardoor overheidsbeleid wordt gelegitimeerd: input of output?, en om de vraag welk type redenering ('beoordelingslogica') de beleidsmaker hanteert om het beleid plausibel te kunnen maken (logic of appropriateness of logic of consequence?).

Het eerste onderscheid roept als vragen op:

I Mag het, is er een grondslag (rechtmatigheid)?

2 Werkt het (doeltreffendheid) en werkt het zo het best (doelmatigheid)?

De tweede invalshoek voegt daar nog de vragen aan toe:

3 Past het, is het politiek haalbaar?

4 Hoort het, is het maatschappelijk aanvaardbaar?

De criteria voor overheidsbeleid zijn dan - in de kortst mogelijke formulering rechtmatigheid, doeltreffendheid en doelmatigheid, haalbaarheid, en aanvaardbaarheid. Hierna worden de twee legitimatiebronnen en de twee vormen van beoordelingslogica nader uitgewerkt.

\section{Legitimatiebronnen}

Scharpf (1999) maakt het onderscheid tussen inputgerichte en outputgerichte legitimatie van overheidsbeleid. In een democratische rechtsstaat opereert de overheid bij de totstandkoming en uitvoering van beleid via door het recht vastgelegde regels. Dit is het zogenaamde legaliteitsbeginsel en legitimeert de inzet van het beleid. Daarnaast gaat het om de vraag of maatschappelijk gewenste doelen al dan niet, meer of minder goed, met overheidsbeleid worden gerealiseerd. Hier gaat het om de beleidsresultaten die het beleid legitimeren; zijn 
die doeltreffend en doelmatig (outputlegitimiteit)? Inputgerichte legitimering wil zeggen dat politieke besluiten zijn terug te voeren op de toestemming van de 'demos', het volk: het gaat hier om government by the people. In het outputperspectief staat democratie voor government for the people. Het criterium voor legitimatie is: oplossing van de collectieve problemen van de samenleving. In dit perspectief past bijvoorbeeld de economische theorie van het overheidshandelen, die gebaseerd is op het kunnen determineren van vormen van marktfalen. Is dat laatste het geval, dan zal in de meeste gevallen een publieke voorzieningswijze een beter resultaat opleveren dan een voorzieningswijze via markten en prijzen. Bij milieubeleid is het marktfalen bijvoorbeeld het bestaan van negatieve externe effecten (voor derden, nu en in de toekomst). Dat is dan het argument voor een doelgericht ingrijpen van de overheid. Andere vormen van marktfalen zijn bijvoorbeeld zuiver collectieve goederen (biodiversiteit zou bijvoorbeeld zo gepercipieerd kunnen worden) of een wenselijk geachte verdeling (ook tussen huidige en toekomstige generaties, en tussen ontwikkelde en ontwikkelingslanden).

Vanzelfsprekend steunt geen enkele democratie alleen maar op de inputgeoriënteerde legitimatie door de manifeste wil van het volk. Het gaat er immers nooit alleen om dat er een rechtsgrond is, maar vooral ook wat er op die grond gedaan wordt. Een inputgeoriënteerde legitimiteit wordt dus altijd aangevuld door een outputgeoriënteerde legitimiteit. In een goed functionerende democratie zijn beide dimensies noodzakelijk en kunnen zij elkaar ook versterken. Enerzijds binden politici de strijd met elkaar aan om de gunst van kiezers, collega-parlementsleden en maatschappelijke organisaties te winnen, om zo de doelen van beleid politiek vast te kunnen stellen (input). Anderzijds moet de uitvoering van de gemaakte keuzes ertoe leiden dat de gestelde doelen doeltreffend en doelmatig (tegen de laagst mogelijke maatschappelijke kosten) worden gerealiseerd (output).

\section{Twee vormen van handelingslogica}

Naast het onderscheid tussen input- en outputlegitimiteit, kan er nog een tweede onderscheid worden gemaakt bij de beoordeling van beleid. Bij dit tweede onderscheid staat de logica centraal die de beleidsentrepreneur gebruikt om de legitimiteit van beleid plausibel te kunnen maken. Die logica laat zich onderscheiden in 'logica van consequentie' (logic of consequence) en 'logica van gepastheid' (logic of appropriateness) (March en Olsen 1995). De hiervoor behandelde criteria rechtmatigheid en doelmatigheid/doeltreffendheid vallen beide onder de eerste logica. De logica van gepastheid introduceert daarnaast de criteria haalbaarheid (intern, binnen de beleidscircuits) en aanvaardbaarheid (extern, bij de beleidssubjecten). In landen met democratische beleidsvormingsconstellaties waarin veel gebruik wordt gemaakt van legitimatieverwervende overleginstituties (zoals in Nederland de SER, enz.) is er een grote verwevenheid tussen 'intern' en 'extern', en komen de criteria haalbaarheid en aanvaardbaarheid dicht bij elkaar te liggen. 
Doelrealisering is het leidmotief van de logic of consequence. In dit perspectief staat rationeel handelen vooral voor weloverwogen handelen met het oog op de realisering van bepaalde doelstellingen met de meest geschikte middelen en methoden. Het ideaaltypische uitgangspunt is dat actoren - een individu, beleidsmaker, groep of organisatie - worden opgevat als handelingsbekwame unitary actors met heldere preferenties. De beleidsmaker wordt in dit perspectief geconfronteerd met duidelijke beleidsproblemen, die niet alleen goed te onderscheiden zijn van andere problemen, maar die ook gemakkelijk in te bereiken doeleinden kunnen worden geëxpliciteerd. Gegeven stabiele en ondubbelzinnige voorkeuren van beleidsactoren, kunnen doeleinden en middelen hiërarchisch worden gerangschikt in volgorde van wenselijkheid en belangrijkheid voor doelrealisering. Een kosten-batenanalyse maakt het mogelijk om uiteindelijk te kiezen voor het alternatief met de hoogste nettobaten.

De logic of appropriateness veronderstelt een geheel andere motivatie: beleidsactoren laten zich bij hun afweging leiden door wat aanvaardbaar en haalbaar is in gegeven situaties. Beleidskeuzes worden sterk beïnvloed door sociale routines en standard operating procedures. Eerder gemaakte keuzes in de beleidsontwikkeling en gevestigde belangen beperken de set van interventiemogelijkheden van beleidsmakers. Beleidsactoren zijn eerder doelzoekend dan doelrealiserend. Zij maken beleidskeuzes op grond van hun percepties over wat 'gepast' en 'passend' is in een gegeven situatie. De opvatting die ze van hun eigen rol hebben en de wijze waarop ze een situatie beoordelen, bepalen daarbij in belangrijke mate wat ze zien als een gepaste handeling. Wat ze gepast vinden kan per (institutionele) setting sterk verschillen. In de wereld van beleid en politiek worden sociale rollen in belangrijke mate gevormd, bemiddeld en gekanaliseerd door historisch gevormde institutionele arrangementen, die een samenbindende functie vervullen in het democratisch beleidsbestel (March en Olsen 1995). Daardoor vormen gearticuleerde preferenties niet alleen, en ook vaak niet in de eerste plaats, een richtsnoer voor het beleid, maar in regels en instituties verankerde waarden en normen.

De logica van consequentie en de logica van gepastheid spelen bij de totstandkoming van beleid gelijktijdig een rol en staan ook in voortdurende wisselwerking met elkaar. Het zijn elkaar aanvullende perspectieven om de dynamiek van overheidsbeleid te bekijken (Wissink 2000: 17-21). De logicavormen bieden dan ook beide handvatten voor de beoordeling van beleid.

Bij de totstandkoming of aanpassing van beleid wordt gediscussieerd en gestreden over de vraag of het voorgestelde beleid aan de bovengenoemde voorwaarden voldoet. Naarmate beleid meer aan de genoemde voorwaarden voldoet, zijn er meer redenen voor maatschappelijke actoren om steun te verlenen aan het beleid. Omgekeerd biedt het gegeven dat beleid niet voldoet aan een of meerdere van deze voorwaarden hen een reden het beleid ter discussie te stellen. Een complicerende factor hierbij is natuurlijk wel dat het als regel moeilijk is om ondubbelzinnig vast te stellen in hoeverre het beleid aan de genoemde voorwaarden voldoet. Bovendien kunnen de voorwaarden op gespannen voet met elkaar staan. 
De vier voorwaarden voor een 'goed beleid' zijn dus te zien als 'piketpaaltjes': in een democratische, rechtsstatelijke beleidscontext zal er altijd aan moeten worden voldaan. Maar daarmee is beleid maken natuurlijk niet het aflopen van een checklist, maar vooral een interactief proces van draagvlakvorming, waarbij kennis/informatie en participatie/interactie belangrijke rollen spelen. Met dit in het achterhoofd gaan we nu nader in op de genoemde voorwaarden.

\subsubsection{RECHTMATIGHEID}

Een eerste voorwaarde waaraan beleid moet voldoen, is dat het rechtmatig is. Er moet een wettelijke grondslag zijn. Die rechtsbasis kent een waarborgfunctie en een instrumentele functie.

\section{Waarborgfunctie}

De waarborgfunctie verwijst naar de bescherming (rechtszekerheid, rechtsgangen, enz.) die burgers en andere rechtssubjecten genieten. Daartoe is het recht gecodificeerd in wetgeving, inclusief de grondwet en internationale verdragen. De waarborgfunctie kent inhoudelijke en procedurele aspecten. Onder inhoudelijke aspecten van rechtmatigheid verstaan we de bescherming van burgers tegen machtsmisbruik en willekeur van de overheid. In de democratische rechtsstaat is de overheid gehouden civiele en politieke grondrechten te respecteren, zoals burgerlijke vrijheden, rechtszekerheid, rechtsgelijkheid, eigendom en het recht van vereniging en vergadering. Naarmate het overheidsbeleid dergelijke grondrechten beter respecteert, is het meer rechtmatig.

Procedurele aspecten van rechtmatigheid zijn bijvoorbeeld de constitutionele spelregels van democratische besluitvorming, zoals toegankelijkheid, openbaarheid, transparantie, en vertegenwoordiging. Naarmate het overheidsbeleid meer in overeenstemming met dergelijke procedures tot stand is gekomen, is het ook in die zin meer rechtmatig. De waarborgfunctie van het recht komt verder tot uitdrukking in rechtsbeginselen die richtinggevend kunnen zijn voor de vorm en de inhoud van het recht. In het geval van het milieubeleid is inmiddels een aantal rechtsbeginselen ook internationaal geaccepteerd, zoals het beginsel dat preventieve maatregelen de voorkeur verdienen, het beginsel dat de vervuiler betaalt, en het voorzorgsprincipe. Uiteraard is dit niet zonder complicaties, zoals op het punt van het kunnen aanspreken van vervuilers (of hun rechtsopvolgers) voor vroegere vervuiling toen bepaalde milieunormen nog niet bestonden. Voor dit probleem van rechtswerking met terugwerkende kracht moet de jurisprudentie een nadere invulling geven van wat achteraf gezien redelijkerwijs wel of niet kan worden toegerekend.

De procedurele kant van het recht impliceert dat de beleidsvorming die een bepaalde procedure heeft doorlopen daarmee juridisch wordt gelegitimeerd. Bij die procesgang kunnen ook eisen zijn opgenomen ten aanzien van participatie en de inbreng van kennis. De rechter kan bijvoorbeeld maatregelen terugdraaien omdat partijen ten onrechte bij de besluitvorming zijn uitgesloten, of omdat 
onvoldoende kennis ter onderbouwing van het beleid is aangedragen. In die zin is het recht dus ten dele structurerend voor de rollen die kennis en participatie in de totstandkoming van beleid kunnen spelen (zie verder par. 3.4). Soms heeft het recht via jurisprudentie hierbij een werking vooraf. Ook achteraf kan de rechter corrigerend optreden en zodoende hernieuwde besluitvorming veroorzaken.

\section{Instrumentele functie}

Naast de waarborgfunctie heeft het recht een instrumentele functie: het wordt door mensen gemaakt, met een doel voor ogen (het komt niet van God, de paus, de natuur of andere vormen van hogerhand). In die zin is het recht ook een instrument dat tot op zekere hoogte substitutie met andere instrumenten toestaat: beleidsmakers kunnen proberen iets te bereiken door bepaalde wet- en regelgeving (juridisch instrumentarium), maar voor hetzelfde doel hadden ze bijvoorbeeld ook een subsidieregeling of een heffing in het leven kunnen roepen (financieel-economisch instrumentarium). Ook kunnen ze proberen het doel te bereiken door overleg en management by speech (sociaal instrumentarium). De praktijk is overigens, zeker bij complexe beleidsproblemen, dat als regel een hele batterij aan overheidsinstrumenten wordt ingezet, opdat die elkaar onderling versterken.

Een voorbeeld van de instrumentele functie van het recht zijn de sociale grondrechten uit de Grondwet. Die brengen een materiële inspanningsverplichting van de overheid met zich mee. Het is de plicht van de overheid het welzijn van haar bevolking te bevorderen. Daarbij gaat het bijvoorbeeld om bestaanszekerheid, volksgezondheid, onderwijs, en ook de bescherming en verbetering van het leefmilieu. Een beleid dat bijdraagt aan de realisering van sociale grondrechten is dus rechtmatig, maar kan op gespannen voet staan met de waarborging van civiele grondrechten. Overheidsbeleid kan willens en wetens inbreuk maken op deze grondrechten, maar de noodzaak en wenselijkheid van de inbreuk moeten dan wel goed worden onderbouwd en volgens zorgvuldige procedures totstandkomen.

\section{Toenemend belang van Europees en internationaal recht}

Europees en internationaal recht zijn van toenemend belang. Een gevolg daarvan is dat veel beleid in verschillende besluitvormingsconstellaties totstandkomt, waarbij uiteenlopende eisen en regels gelden. De besluitvorming, uitkomsten, uitvoerings- en handhavingspraktijken op verschillende overheidsniveaus kunnen met elkaar interfereren. Dit geldt in toenemende mate voor het milieubeleid. Bij het milieubeleid is een vergelijking tussen verschillende landen interessant: hoe gaan andere landen om met bijvoorbeeld het nitraatprobleem? Bijzondere aandacht verdient de verhouding tussen nationaal beleid en Europees en internationaal beleid. Het gaat daarbij om de uitvoeringsplicht die de Nederlandse overheid heeft ten aanzien van Europese milieuregels. Die verschillende regelgevings- en besluitvormingsconstellaties en de 'scharnierfunctie' die de nationale overheid heeft te vervullen, krijgen in hoofdstuk 5 van dit rapport nog nadere aandacht. 


\subsubsection{DOELTREFFENDHEID EN DOELMATIGHEID}

De tweede voorwaarde voor goed beleid is dat het doeltreffend (effectief) en doelmatig (efficiënt) moet zijn. Beleid is doeltreffend indien de implementatie van de gekozen beleidsmaatregelen leidt tot realisering van de beoogde doelen van dat beleid. Als dit tegen de laagst mogelijke kosten gebeurt, is het tevens doelmatig. Doeltreffendheid en doelmatigheid vooronderstellen dus dat het beleid doelgericht is en is gebaseerd op doelrationaliteit. De doeltreffendheid van het beleid kan achteraf worden vastgesteld, mits er adequate indicatoren kunnen worden ontwikkeld om de mate van doelrealisering te beoordelen. Omdat er in veel gevallen verschillende maatregelen denkbaar zijn om specifieke beleidsdoelen te realiseren, vergt de keuze tussen concurrerende beleidsmaatregelen een inschatting vooraf van hun relatieve doeltreffendheid.

Een adequate onderbouwing van de verwachte doeltreffendheid van toekomstig beleid is van groot belang, want zij biedt een reden om het beleid te aanvaarden. Die onderbouwing is afhankelijk van een goed begrip van het probleem, opdat kan worden ingeschat welke effecten de voorgestane maatregelen zullen of kunnen hebben en in hoeverre de maatregelen ook oplossingen kunnen of zullen zijn. Wetenschappelijke kennis over causale relaties speelt bij deze inschatting een belangrijke rol. Het bepalen van de doeltreffendheid vindt dan ook plaats in een met wetenschappelijke kennis en argumenten gevoed debat over feiten, samenhangen en wetmatigheden. Maar dit vormt nog geen garantie voor succes. Naast situaties waarin een probleem ondanks een voldoende inzet van wetenschappelijke kennis toch niet succesvol is aangepakt, zijn er ook situaties waarin de inzet van wetenschappelijke kennis als zodanig problematisch is. Niet alle kennis die de beleidsmaker tot zijn beschikking zou willen hebben ter onderbouwing van de doeltreffendheid van zijn beleidsvoornemens, is daadwerkelijk beschikbaar of kan worden ontwikkeld. Het is ook denkbaar dat de wetenschappelijke kennis waarover een beleidsmaker beschikt controversieel is. Dit is een van de verschillende vormen van onzekerheid (Van Asselt 2000: 84-91); zij kan een goede inschatting van de doeltreffendheid van verschillende beleidsalternatieven vooraf bemoeilijken. De mate van onzekerheid en variabiliteit kan men met behulp van methoden uit de waarschijnlijkheidsberekening trachten te bepalen. Die bepaling kan zinvol zijn wanneer het beleid risicomijdende maatregelen wil treffen. Verder kan toepassing van waarschijnlijkheidsrekening aangeven dat de onzekerheden zodanig fundamenteel zijn dat zelfs de variabiliteit niet te bepalen valt.

\subsubsection{HAALBAARHEID}

Bij haalbaarheid gaat het om de vraag in hoeverre voorgestelde concrete maatregelen in politiek opzicht kunnen worden gerealiseerd. Haalbaarheid onderscheidt zich van maatschappelijke aanvaardbaarheid doordat het niet gaat om de "juistheid' van beleid, maar om de bereidheid om mee te werken aan de realisatie ervan. Dit politieke draagvlak hangt niet primair af van overeenstemming op 
grond van gedeelde normatieve of culturele oriëntaties, maar van politiek-strategische overwegingen en inschattingen. Vanzelfsprekend kan er wel een relatie tussen beide bestaan. Articulatie van de haalbaarheid van beleid vindt plaats in al dan niet geïnstitutionaliseerde onderhandelingssituaties (in de eerste plaats in het parlement, maar ook bijvoorbeeld in de ser, of meer ad hoc in het overleg tussen convenantpartijen).

\subsubsection{AANVAARDBAARHEID}

Aanvaardbaarheid heeft betrekking op de mate waarin het beoogde beleid aansluit bij normatieve en culturele oriëntaties in de samenleving. Normatieve oriëntaties hebben betrekking op ideeën over goed en kwaad; culturele oriëntaties betreffen de preferenties voor bijvoorbeeld individuele of collectieve probleemoplossing (Douglas en Wildavsky 1982). Deze oriëntaties leiden tot min of meer coherente beoordelingskaders van waaruit actoren betekenis geven aan observaties en feiten, en op grond waarvan zij afwegingen kunnen maken. Aanvaardbaarheid heeft dus betrekking op de mate waarin beleid aansluit bij (inter)subjectieve denkbeelden en gevoelens over maatschappelijke noden en misstanden, en op de rol die de overheid behoort te vervullen bij het oplossen van die problemen. Actoren in het beleidsproces refereren bij het bepleiten van hun opvattingen en belangen daarom vaak aan normen en waarden die leven in de samenleving. Ook de articulatie van (potentiële) aanvaardbaarheid vindt dus plaats in het publieke debat. Wat burgers aanvaardbaar vinden, en de daaronder liggende oriëntaties, wordt overigens weer beïnvloed door hun ervaringen in het verleden, bijvoorbeeld eerder beleid of bepaalde instituties die wel of niet als doelmatig zijn ervaren.

In concrete probleemsituaties kunnen de betrokken maatschappelijke groepen soms grote verschillen vertonen in hun normatieve of culturele oriëntaties. Dergelijke situaties zijn 'ambigu' omdat er dan geen ondubbelzinnig of dominant kader is om de aanvaardbaarheid van het beleid te beoordelen. Er zijn verscheidene situaties bekend waarin de verschillen tussen beoordelingskaders hebben geleid tot een (aanvankelijke) patstelling in de beleidsvorming (Van Eeten 1999). In de geschiedenis van het Nederlandse milieubeleid hebben dergelijke situaties zich ook voorgedaan (zie hoofdstuk 4).

Een ander probleem ten aanzien van (het inschatten van) de aanvaardbaarheid is dat het 'schieten op een bewegend doel' is. Burgers kunnen hun eisen, verwachtingen en beoordelingen in de loop van het beleidsproces bijstellen, in casu: opschroeven. Wat aanvankelijk aanvaardbaar leek te zijn, kan dat uiteindelijk toch niet blijken te zijn. In de economische theorie staat dit punt van (niet rekening houden met) de anticipatie van de beleidssubjecten op een bepaald beleid, bekend als de 'Lucas-kritiek'.

\section{Aanvaardbaarheid en transactiekosten van beleid}

De maatschappelijke aanvaardbaarheid is vooral van belang indien het beleid een 
uitwerking moet krijgen in het handelen van bedrijven en consumenten: zij moeten hun gedrag aanpassen. Overheidsbeleid heeft de wind in de zeilen als voor burgers en bedrijven de 'prikkelstructuur' van de instrumentele vormgeving van het beleid zodanig is dat het 'algemene belang' als het ware samenvalt of 'meelift' met hun (gepercipieerde) eigenbelang. Dan zijn de transactiekosten van het beleid het laagst (Hazeu 2ooob: 92-96). Die transactiekosten verbonden aan de institutionele capaciteit om beleid uit te voeren, hebben velerlei vormen: de 'bureaucratie' die regels maakt, maar ook de monitoring en controle op de naleving ervan, de administratieve lasten voor burgers en bedrijven om bijvoorbeeld belastingen in te houden of subsidieregelingen uit te voeren, enzovoort. Bij dit punt van de transactiekosten van het overheidsbeleid zijn we terug bij de discussie onder het kopje 'rechtmatigheid': indien burgers en bedrijven zich sterk verzetten tegen een beleid, kan de overheid machtsmiddelen inzetten om het gewenste gedrag af te dwingen. Dit vraagt uiteraard om een goede onderbouwing en zorgvuldige procedures, maar betekent ook dat de effectuering van het beleid in het uiterste geval een (bereidheid tot) grootschalige en langdurige inzet van geweld vergt. Hoewel dit laatste rechtmatig kan zijn (de overheid heeft immers het geweldsmonopolie in een rechtsstaat), vinden beleidsmakers dat middel in het algemeen onwenselijk. Men kan dan (in economische terminologie) zeggen dat de transactiekosten van het desbetreffende beleid te hoog zijn, of anders (in sociologische termen): dat het beleid niet wordt aanvaard.

\subsection{SPANNINGEN TUSSEN DE CRITERIA BIJ MILIEUBELEID}

De in de vorige paragraaf geschetste vier voorwaarden waaraan beleid moet voldoen, spelen een rol bij discussies over nieuw beleid of over de aanpassing van bestaand beleid. Bij die discussies kunnen argumenten ten aanzien van elk van de vier voorwaarden expliciet worden ingebracht en waar dit niet gebeurt, spelen ze impliciet op de achtergrond toch een rol. Wie bedenkingen heeft bij bestaand beleid zal in zijn kritiek al snel beginnen bij een of meer van de vier voorwaarden. Beleid zal immers rechtmatig, doeltreffend en doelmatig, haalbaar en aanvaardbaar moeten zijn. Een gebrek op een van deze voorwaarden kan aanleiding zijn tot hernieuwde discussie. 'Goed beleid' is daarmee op te vatten als een resultaat dat voldoet aan al deze voorwaarden, en de uitkomst is van een zoektocht en strijd. Ook de ontwikkeling van het milieubeleid kan in deze termen worden geduid.

Zoals de geschiedenis van het milieubeleid laat zien (zie hoofdstuk 2), kan het proces van beleidsvorming moeizaam verlopen. Vaak kostte het tijd om naar aanleiding van nieuwe milieuproblemen beleid te creëren. Steeds was er discussie over de aanvaardbaarheid van overheidsbeleid, of juist van het uitblijven daarvan. De groei van de milieubeweging heeft een belangrijke rol gespeeld bij de mobilisering van de maatschappelijke aanvaardbaarheid van beleid. Door het ingrijpende karakter van de benodigde maatregelen stond hierbij ook steeds de politieke haalbaarheid ter discussie. Dit werd nog gecompliceerder doordat - door onzekerheden over de aard van de problemen - ook de doeltreffendheid van het voorgestelde beleid slechts na verloop van tijd duidelijker kon worden. Het 
vergaren van wetenschappelijke kennis over de milieuproblemen speelde bij de legitimering van het beleid dan ook een belangrijke rol, zonder dat er altijd 'wetenschappelijke zekerheid' kon worden geboden.

Ondanks deze spanningen rond de voorwaarden voor beleid is er in de loop van de decennia toch veel milieubeleid ontwikkeld. Hoewel internationaal overleg hierbij een belangrijke rol speelde, gebeurde dit tot de jaren tachtig toch vooral binnen de nationale context. Gegeven het lokale en regionale karakter van de problemen paste dit ook goed. De mogelijkheden om binnen deze context door middel van overleg tot beleid te komen dat ook aanvaardbaar was, speelde het laatste decennium van de vorige eeuw een belangrijke rol. Dit leidde soms tot spanning met de eisen van rechtmatigheid en tot een discussie over de selectie van de betrokkenen bij het overleg. Niettemin droeg het bij aan de relatief succesvolle aanpak van de beheersbare, 'groene' problemen. Het merendeel van deze 'oude' milieuproblemen bevindt zich inmiddels van dan ook in de beheersfase en de zorgen liggen nu vooral bij een goede implementatie en handhaving.

\section{Grotere en andere onzekerheid}

Ook voor de moeilijke milieuproblemen zal er moeten worden gezocht naar beleid dat voldoet aan de voorwaarden voor goed bestuur. Maar de schaal en aard van de problematiek en van de bestuurlijke en maatschappelijke context waarin die moet worden aangepakt, zijn van een wezenlijk andere orde (WRR 2002b; Hazeu en Schoonenboom 2002). Bij de milieuproblematiek spelen verschillende factoren tegelijkertijd een rol. De problemen hebben betrekking op grotere gebieden en spelen zich over een langere tijd af. Er zijn veel meer betrokkenen en veroorzakers, en er zijn ook meer geadresseerden wanneer wordt geprobeerd om deze problemen aan te pakken. Die aanpak betekent bovendien dat productie- en consumptiepatronen ingrijpend moeten worden gewijzigd. Verder is er een belangrijke verdelingsdimensie die is gerelateerd aan het vraagstuk van armoede en (onder)ontwikkeling in de wereld.

Bovendien brengt de andere aard van de hardnekkige milieuproblemen met zich mee dat de ermee gemoeide onzekerheid soms ook een ander karakter krijgt (Wissink 2001). Er zijn grotere onzekerheden over de doeltreffendheid van maatregelen omdat de causale relaties, en daarmee gevolgen van (alternatief) beleid, moeilijk zijn vast te stellen. Er is daarnaast een relatief grote onzekerheid, omdat preferenties minder gearticuleerd en meer diffuus zijn (hoe zwaar willen we milieuwaarden laten wegen ten opzichte van andere waarden?), zodat de aanvaardbaarheid van het beleid moeilijk is te voorzien. Bovendien zijn de belangentegenstellingen groter vanwege het grote aantal betrokkenen in ruimte en tijd; denk hierbij aan de spanning tussen de huidige versus de toekomstige generaties en aan de ongelijke belangen en aspiraties van de westerse landen versus de ontwikkelingslanden. Daardoor is compromisvorming via een institutionalisering van de onderhandelingen moeilijker te verwezenlijken. 'Geven en nemen' lukt meestal het beste als er gelijk wordt overgestoken, maar minder goed als partijen nu moeten geven om er mogelijk in de toekomst iets voor terug te krijgen. 
Geven en nemen lukt bovendien gemakkelijker als het zich afspeelt tussen partijen die eenzelfde 'culturele setting' hebben dan wanneer die partijen cultureel ver uit elkaar staan.

Ten slotte zijn er, zeker bij milieuproblemen op wereldschaal, ook juridische onzekerheden. Er bestaat immers vaak geen 'dekkende' publieke wereldinstantie, hetgeen een oordeel over de rechtmatigheid van beleid kan bemoeilijken. Een mogelijk doeltreffend beleid dat bovendien haalbaar lijkt, kan door lokale of internationale rechtsregels worden bemoeilijkt of geblokkeerd. In economische termen is dit te duiden als een eigendomsrechtenprobleem: wie heeft er een recht om te vervuilen? Of omgekeerd: wie heeft er een recht om een schoon milieu te claimen? In de meeste gevallen is dit niet ondubbelzinnig vastgesteld of vast te stellen en is er bij dit onderwerp sprake van een aanhoudende belangenstrijd.

\section{Omvangrijke potentiële gevolgen}

De gevolgen van de milieuproblemen zijn dus vaak niet goed vast te stellen; tegelijkertijd kunnen ze potentieel wél een enorme omvang hebben. Daardoor ontstaat er een spanning tussen de wens om iets aan de potentiële problemen te doen vanuit aanvaardbaarheidsoverwegingen, en de vaststelling van de doeltreffendheid van het beleid. In Europa is dit dilemma ook bij rechtmatigheid terug te zien. Waar enerzijds een wetenschappelijke onderbouwing van de noodzaak van het milieubeleid wordt geëist, is anderzijds het voorzorgsbeginsel opgenomen in de verklaring van Rio de Janeiro (1992), en daarmee erkend door de VN. Dit beginsel stelt dat indicaties die geen volledig bewijs impliceren geen reden mogen zijn voor politieke inactiviteit. De veranderende aard van de onzekerheid over de milieuproblematiek en over de effectiviteit van potentiële maatregelen zet de legitimering van het beleid onder druk.

\section{Verschillende bestuursschalen van milieubeleidsvorming}

De veranderde karakteristiek van de milieuproblematiek heeft nog op een andere manier gevolgen voor de te verwachten rechtmatigheid van het toekomstige beleid. Door de toegenomen schaalgrootte van de milieuproblemen kan dit beleid in een groot aantal gevallen slechts effectief zal zijn als het bovennationaal is. De schaal van de moeilijke milieuproblemen overstijgt immers de nationale grenzen. In de achterliggende decennia is dit steeds meer erkend. Het groeiende belang van het Europese milieubeleid geeft daar blijk van. In hoofdstuk 2 is al gesignaleerd dat een groot deel van het Nederlandse milieubeleid in Europees verband wordt vastgesteld. Bij de aanstaande uitbreiding van de EU naar Midden- en OostEuropa zal er verder worden geappelleerd aan het Europese milieubeleid (WRR 2001: par. 7.5; Henzen 2001). Waar milieuproblemen ook de continentale schaal overstijgen (zoals bij het broeikaseffect en de afnemende biodiversiteit), worden wereldwijde internationale afspraken steeds belangrijker. Daarbij kan voor de EU-landen de Unie een belangrijker actor gaan vormen voor de implementatie en handhaving van die afspraken (Hazeu en Schoonenboom 2002). 
Door de grotere schaal van de problemen zijn dus meerdere bestuurslagen bij de aanpak ervan betrokken. Doordat het beleid in verschillende sferen totstandkomt, variëren ook de voorwaarden waaraan het beleid moet voldoen vanuit het oogpunt van rechtmatigheid. Dat kan ertoe leiden dat er toenemende spanningen ontstaan met de andere voorwaarden. Waar bijvoorbeeld het Europese beleid in Brussel wordt vastgesteld, zal de uitvoering - en dus de vraag naar de aanvaardbaarheid - bij de (beleidssubjecten in de) lidstaten liggen.

\section{Haalbaarheid wordt moeilijker}

Door de veranderende aard van de milieuproblematiek en de zich wijzigende maatschappelijke context wordt het ook moeilijker om een haalbaar beleid te vormen. Doordat de problemen een grotere schaal hebben en het aantal veroorzakers van de milieuproblemen veel groter is, treft de aanpak van problemen al snel een veel grotere groep mensen en bedrijven. Bovendien zijn er vele (inter)nationale politieke actoren die bij de aanpak van problemen moeten worden betrokken, terwijl hun belangen soms sterk verschillen. De haalbaarheid van maatregelen komt hierdoor onder druk te staan. In het geval van de EU ontstaat er vaak nog wel beleid, maar komt de nationale uitvoering onder druk te staan. Bij internationale afspraken is het zowel moeilijk om betekenisvol beleid tot stand te brengen als om het geïmplementeerd te krijgen. Het gevaar hier is dat beleid op een 'declaratief' niveau blijft steken.

Ook als er wél beleid totstandkomt is het voor de individueel aangesprokenen vaak niet direct duidelijk hoe de concrete maatregelen bijdragen aan de oplossing van een langetermijnprobleem op grote schaal. De spanning tussen haalbaarheid en de vaststelling van doeltreffendheid maakt het milieubeleid er dus niet makkelijker op. Gegeven dergelijke spanningen wordt er op nationale schaal vaak gezocht naar multi-actoroplossingen, zoals convenanten, platforms en (lichte) vormen van overleg en institutionalisering om de vele betrokken actoren 'mee' te krijgen (vgl. Hazeu 2000a; 200ob; WRR 2002b). Ook op internationaal niveau speelt dit soort processen; denk aan de 'duurzaamheidstop' in Johannesburg (2002) die wel heeft geleid tot enkele afspraken, maar die vooral ook tot doelstelling had om te blijven mobiliseren. Het is op internationaal niveau echter lastiger resultaat te boeken, gegeven de grote afstand tussen de internationale beleidsmakers en de lokale aangesprokenen van het beleid.

\section{Divergerende opvattingen over aanvaardbaar beleid}

Ook ten aanzien van de aanvaardbaarheid van beleid, of juist van het uitblijven daarvan, vindt er een problematisering plaats. Hiervoor is al geconstateerd dat bij de internationale milieuproblemen er een steeds grotere groep landen betrokken is bij de totstandkoming van beleid. In een optimistische optiek kan dat leiden tot een geleidelijke convergentie van opvattingen. Het is evenwel ook denkbaar dat de kans juist kleiner wordt dat opvattingen over aanvaardbaarheid overeenkomen (Scharpf 1999: 6-28). Ook de houding ten aanzien van risico's blijkt in sterke mate door culturele houdingen te worden bepaald (Schwarz en Thompson 1990: 1-13). Als algemene teneur valt er daarnaast te constateren dat de maatschappe- 
lijke weerstand tegen het lopen van risico's toeneemt (Beck 1992; Furedi 1997), wat een extra druk legt op beleidsmakers. Tegelijkertijd echter eist de maatschappij bij overheidsmaatregelen ook een steeds hardere onderbouwing, waardoor maatregelen uit voorzorg steeds onder druk komen te staan.

Deze ontwikkelingen zorgen ervoor dat de opvattingen over de aanvaardbaarheid van beleid ver uit elkaar kunnen liggen. Zeker wanneer de noodzaak van het beleid vanuit een oogpunt van doeltreffendheid moeilijk is vast te stellen, kan er dan een gepolariseerde discussie over de (on)wenselijkheid van een bepaald beleid ontstaan (Van Eeten 1999). Zo'n constellatie maakt eens temeer duidelijk dat het politieke proces meer is dan het vervullen van een passieve makelaarsfunctie van preferenties van (groepen van) burgers, maar dat beleidsmakers als politieke entrepreneurs moeten optreden.

Het algemene beeld is dat door de toenemende variatie van milieuproblemen, die bovendien spelen op verschillende ruimtelijke schalen, het beleid ook op diverse bestuurlijke schalen tot stand moet komen. Waar het meeste milieubeleid oorspronkelijk vooral in een nationale setting is gevormd, is dat kader nu als regel niet toereikend. Op elk van die bestuurlijke schalen zal beleid moeten worden geformuleerd dat voldoet aan de vier voorwaarden voor goed bestuur.

$\mathrm{Nu}$ zijn problemen bij de zoektocht naar beleid dat voldoet aan de voorwaarden niet nieuw. Ook de vaststelling van het nationale beleid leidde vroeger vaak tot hevige discussies (Reijnders 2002). Ook daar was er ex ante geen overeenstemming ten aanzien van de maatschappelijke aanvaardbaarheid. Ook daar was de politieke haalbaarheid im Frage. En ook daar was niet altijd evident wat de meest doelmatige aanpak was. Toch ontstond er uiteindelijk - min of meer - succesvol beleid. Kunnen er net als rond de 'groene' nationale problemen, ook succesvolle internationale arrangementen ontstaan? De mogelijkheden daartoe lijken door de beschreven ontwikkelingen onder druk te staan. Een grote variatie in de opvattingen over aanvaardbaarheid staat op gespannen voet met de afnemende mogelijkheden om de te verwachten doeltreffendheid van beleid vooraf in te schatten. Waar de overheid met het oog op risicovermijding (voorzorg) toch tot beleid probeert te komen, komt de haalbaarheid van het beleid al snel onder druk te staan, omdat de aangesprokenen geen direct verband zien tussen de 'vage' langetermijngevaren en hun eigen concrete gedrag. Het is, kortom, op internationaal niveau moeilijker om tot beleid te komen dat aan de vier voorwaarden voldoet, omdat het moeilijker is om de invulling van die voorwaarden vooraf vast te stellen, en omdat ze deels ook op gespannen voet met elkaar staan. De concrete gevolgen hiervan hangen mede af van de kenmerken van de arrangementen waarmee de moeilijke milieuproblemen worden aangepakt. Hoe wordt met name met kennis/informatie en participatie/interactie omgegaan om draagvlak te verwerven? Een nadere analyse van die vraag is nodig. Dit biedt de mogelijkheid om vervolgens tot een toespitsing van de problematiek te komen, en tot een empirische toetsing. 


\subsection{DE ROL VAN KENNIS EN PARTICIPATIE IN DE BELEIDSVORMING}

Zoals hiervoor is beschreven, moet er bij de vorming van 'goed beleid' aan vier voorwaarden zijn voldaan. Dat zijn geen ja-neekwesties; de crux is dat de overheid er ook actief aan kan en moet werken om een draagvlak voor haar beleid te vormen. Dat is het politieke entrepreneurship waaraan hiervoor is gerefereerd. Een beleid dat in eerste aanleg niet haalbaar of aanvaardbaar lijkt te zijn, kan dat soms toch worden als er een groeiende sense of urgency ontstaat. In dit proces van draagvlakvorming kunnen (een toename van) informatie en kennis en (veranderingen in de) participatie - waardoor een probleem, preferentie of oplossingsrichting van gewicht verandert - een belangrijke rol spelen. Langs die lijn valt bijvoorbeeld te analyseren waarom rokers decennialang niet al te zwaar zijn bestreden en nu toch steeds meer in het defensief zijn geraakt. Eenzelfde redenering geldt voor boeren en de nadelige gevolgen van hun productie (enerzijds weten we meer van mest en zure regen en anderzijds zijn er steeds minder boeren). Een ander voorbeeld betreft GistBrocades in Delft en de manier waarop zijn stankoverlast aan banden is gelegd (in een groeiende stad verdiende een steeds kleiner aantal mensen zijn brood bij 'de Gist').

De inbreng van kennis en participatie zijn ingebed in besluitvormingsarrangementen. Subparagraaf 3.4.1 bespreekt de algemene dynamiek en het cyclische karakter van besluitvorming in een democratische context. De volgende subparagrafen gaan achtereenvolgens in op de bijdrage van kennis (subpar. 3.4.2) en het belang van participatie (subpar. 3.4.3). Deze paragraaf sluit af met een typering van de arrangementen van het milieubeleid en van de dilemma's die daarin kunnen ontstaan (subpar. 3.4.4). Het biedt zo een opstap naar de empirisch analyse van hoofdstuk 4 .

\subsubsection{DE VORMING VAN DRAAGVLAK VOOR BELEID ALS CYCLISCH PROCES}

\section{Fasen en functies}

In deze paragraaf richten we de aandacht op de problemen rond de draagvlakvorming van het beleid met betrekking tot de moeilijke milieuproblemen. Dat proces wordt hier geanalyseerd als een zoektocht en strijd, waarbij vele partijen proberen om tot oplossingen te komen die aan de voorwaarden voor goed beleid voldoen. Om zicht te krijgen op de dynamiek van dit proces kan gebruik worden gemaakt van een van de vele analytische modellen van beleidsvorming (Van der Graaf en Hoppe 1989: 84-9o). Deze modellen redeneren aan de hand van een schema waarbij de besluitvorming verschillende fasen doorloopt. Na de probleemerkenning volgen achtereenvolgens beleidsvoorbereiding, beleidsvaststelling, beleidsuitvoering, beleidsevaluatie en eventueel beleidsaanpassing. Deze fasemodellen zijn een ideaaltype met een heuristische functie. Ze bieden dus zeker niet altijd een accurate weergave van het feitelijke verloop van besluitvorming in de praktijk, maar bieden een analytisch kader om het cyclische karakter van het proces van draagvlakvorming te verduidelijken. Het draait er dus niet 
zozeer om een bepaalde fase van beleidsvorming ondubbelzinnig te kunnen vaststellen, maar wel om het benoemen van de functies die ermee verbonden zijn.

\section{Signalering}

De eerste fase van een beleidsvormingsproces betreft de signalering van een probleem. Dit kan zowel het gevolg zijn van de erkenning van een nieuwe probleemsituatie, als een hernieuwde problematisering van al langer bestaande problemen. In hoofdstuk 2 is bijvoorbeeld gebleken dat een veranderde houding ten aanzien van de milieuproblematiek ook heeft geleid tot ingrijpende beleidswijzigingen (van compartimentgericht naar themagericht beleid). In die zin kunnen argumenten ten aanzien van de voorwaarden aanleiding geven tot beleidsvorming. Een milieuprobleem wordt als een normatief-inhoudelijk vraagstuk gearticuleerd, maar hoe dat gebeurt staat niet bij voorbaat vast. De aanleiding kan bijvoorbeeld liggen bij onrust onder boeren; bij onderzoekers die aan de bel trekken; bij een schaap dat omvalt; of bij omwonenden die klagen. Daarmee is dus ook niet op voorhand aan te geven tot welke instantie men zich zal wenden. De eerste taak van de politiek is het al dan niet serieus nemen van deze klachten en geluiden: iets wordt tot dan toe niet gehoord, of niet gekend, en moet nu met spoed worden geagendeerd, of men besluit dat het probleem in kwestie geen politieke aandacht verdient. Bij deze discussie nemen overwegingen uit de sfeer van de aanvaardbaarheid van (mogelijke) beleidsmaatregelen een belangrijke plaats in.

\section{Beleidsvoorbereiding}

$\mathrm{Na}$ de erkenning van een probleem en van de wens om daar als overheid wat aan te doen, zal er - spoedig of langzaam - een overgang plaatsvinden naar de beleidsvoorbereiding. Naast argumenten uit de sfeer van de aanvaardbaarheid zullen nu ook argumenten uit de sfeer van de doeltreffendheid belangrijker worden. In deze fase verwerft men kennis over de causale relaties achter de gearticuleerde maatschappelijke problemen. Detectie, opsporing, inventarisatie en aanwijzing zijn kernbegrippen. Daarnaast melden zich verschillende stakeholders. Afhankelijk van de vormgeving van het besluitvormingsproces kunnen de diverse stakeholders worden betrokken bij de discussie over het desbetreffende probleem en vindt ook een verbreding van de problematiek plaats. Nu komt het proces van meningsvorming tot volle wasdom. Tegelijkertijd zullen diverse actoren proberen om de discussie vanuit hun eigen strategische positie (bij) te sturen. Vaak vindt hierbij ook een op verschillende fronten gevoerde strijd plaats om een 'plekje aan de tafel' te bemachtigen.

In de fase van beleidsvoorbereiding is het zaak het proces niet te snel te 'trechteren' in de richting van één oplossing. Een goede beleidsvoorbereiding bestaat er juist uit dat men verschillende handelingsperspectieven en daarop geënte alternatieven naast elkaar zet en de daarvoor relevante kennis en informatie verzamelt. Ook een 'niets doen' past in zo'n kader. In het algemeen gebeurt dit te weinig in de beleidsvoorbereiding. 


\section{Besluitvorming}

Om tot succesvol beleid te komen, dient de meningsvorming over beleidsproblemen op enig moment over te gaan in besluitvorming. De beleidsvoorbereiding moet dan uitmonden in beleidsvaststelling. Die overgang kan lang op zich doen wachten. Meer dan eens kan het proces van besluitvorming - wegens het achterwege blijven van overeenstemming over de aanvaardbaarheid van het beleid geblokkeerd raken. In het bijzonder bij situaties waarin de onzekerheid groot is en om principiële of praktische redenen niet kan worden weggenomen, kunnen sterk normatief getinte discussies tot een blokkade in de besluitvorming leiden. Komt het tot besluitvorming, dan gaat het vooral om de vragen of de overheid de regels mag of moet opstellen en of voorgestelde oplossingen politiek-bestuurlijk en maatschappelijk ook zullen passen. Daarmee bereikt men een voorlopige 'sluiting' van het beleidsprobleem en brengt men de voorstellen in overeenstemming met de geldende regels en procedures van de rechtsstaat. Politiek gezien wordt duidelijk welke belangen men wel, en welke minder of niet relevant vindt terwille van de haalbaarheid. Deze fase mondt uit in een concreet politiek besluit dat ook formeel wordt bekrachtigd.

\section{Uitvoering}

Nadat het beleid is vastgesteld, zal het moeten worden uitgevoerd. In de fase van de uitvoering vindt impliciet een 'afrekening' plaats ten aanzien van de invulling van de verschillende voorwaarden. Elke voorwaarde kan aanleiding geven tot hernieuwde problematisering van het beleid. Er kan blijken dat het beleid niet goed werkt; dat het niet goed wordt uitgevoerd; de rechter kan uitspraken doen die de beoogde werkzaamheid van het beleid beperken (hetgeen van belang is omdat we zowel met de Nederlandse als EU-overheid te maken hebben; zie ook WRR 2002a); en er kan ook nog blijken dat er vraagtekens worden geplaatst bij de aanvaardbaarheid van het beleid. In elk van deze gevallen vindt er feitelijk een hernieuwde signalering van het beleidsprobleem plaats. Er wordt feedback gegeven ten aanzien van de vier voorwaarden (Deutsch 1966; Etzioni 1968). De mate waarin een beleidsbestel erin slaagt in dit proces te leren hangt in hoge mate af van feedback-processen en het vermogen om informatie te verwerken en veranderingen door te voeren.

In de voorgaande typering is het besluitvormingsproces analytisch opgedeeld in verschillende fasen, waarin de vier voorwaarden voor beleid moeten worden ingevuld. Ondanks deze indeling in fasen is het feitelijke verloop van dit proces vaak 'rommelig'. In de praktijk spelen argumenten met betrekking tot de verschillende voorwaarden vaak door elkaar een rol. Steeds kan worden teruggekeerd naar eerdere fasen in de besluitvorming. Vastgesteld beleid kan in het vervolg opnieuw ter discussie worden gesteld aan de hand van een van de vier voorwaarden. De legitimering van beleid komt nu eenmaal tot stand in een open en democratische context en blijft in die zin altijd aan debat onderhevig.

De inschatting en de invulling van de vier voorwaarden bij de totstandkoming van beleid vindt (uiteindelijk) in het parlement plaats. Bij de totstandkoming en 
beoordeling van (milieu)beleid zijn er twee factoren van belang die in belangrijke mate kunnen bijdragen aan de draagvlakvorming voor democratisch beleid: kennis en informatie en participatie en interactie. De volgende subparagrafen gaan in op de manier waarop deze factoren in beleidsarrangementen zijn ingebed.

\subsubsection{HET BELANG VAN KENNIS EN INFORMATIE}

\section{De rol van kennis in verschillende fasen}

Bij de besluitvorming maakt men gebruik van kennis als middel om tot een invulling van de vier voorwaarden te komen. Kennis is dus een middel bij het verwerven van draagvlak voor een beleid. Wat de disciplinaire invalshoek betreft, ligt het voor de hand dat in het milieubeleid vooral natuurwetenschappelijke kennis van belang is. De laatste jaren benadrukt men dat ook andere kennis een belangrijke rol kan spelen, bijvoorbeeld psychologische kennis om burgers/consumenten in gedragstransitieprocessen te 'trekken'. Daarnaast is er steeds meer behoefte aan multidisciplinaire kennis.

De rol van kennis verschilt per fase van het besluitvormingsproces: van klokkenluiden bij de probleemerkenning, naar analyseren van problemen en mogelijke oplossingen bij de meningsvorming, naar onderzoeken van maatschappelijke voorkeuren bij de besluitvorming, tot vaststellen van de effecten van het beleid en de maatschappelijke tevredenheid hierover bij de uitvoering. Er spelen dus ook heel verschillende typen kennis en informatie een rol; de ene kennissoort richt zich op het verduidelijken van de aard van causale relaties, de andere kennissoort is erop gericht een beeld te krijgen van maatschappelijke preferenties. Onzekerheid hierover kan betrekking hebben op alle vier voorwaarden die bij de legitimering van beleid een rol spelen.

In het verleden heeft natuurwetenschappelijke kennis over causale verbanden rond milieuproblemen de meeste aandacht gekregen. Maar naarmate het milieubeleid meer in de richting is verschoven van probleemsignalering naar (ideeënvorming over) oplossingen, biedt ook kennis over (de mechanismen om invloed uit te oefenen op) maatschappelijke overtuigingen en preferenties een belangrijke input. Het is dan ook niet verwonderlijk dat het laatste decennium ook sociaal-wetenschappelijke kennis in brede zin meer aan belang heeft gewonnen.

\section{Mogelijkheden en beperkingen van de welvaartsanalyse}

De moderne economische welvaartstheorie (welfare economics), en de daarop gebaseerde kosten-batenanalyse, biedt een voorbeeld van een benadering waarin in beginsel wordt geprobeerd om door middel van kennis te komen tot het 'beste beleid' (het grootste surplus van totale maatschappelijke baten boven totale maatschappelijke kosten). Eenvoudig en idealiter gezegd, probeert de welvaartsanalyse die beleidsmaatregelen op te sporen die een zo hoog mogelijke welvaart opleveren gegeven de causale verbanden en op basis van een samenstel van individuele preferenties. Kennis speelt hierbij een cruciale rol. In de eerste plaats is dit kennis over die causale verbanden. Die is nodig om de verschillende maatregelen 
te kunnen opsporen die in principe doeltreffend zouden kunnen zijn. In de tweede plaats betreft het kennis van preferenties, waarden en normen. In de welvaartstheorie gaat het daarbij vooral om de 'ruilwaarden' ten aanzien van de doelstellingen die men met het beleid probeert te bereiken. In weinig complexe situaties waarin sprake is van weinig onzekerheden kan op deze wijze het handelingsperspectief worden bepaald dat de grootste welvaart oplevert.

De mogelijkheden om door middel van kennis onzekerheden over beleid weg te nemen, zijn echter beperkt. Soms kan de onzekerheid niet met behulp van wetenschappelijke kennis worden verkleind. De welvaartsanalyse kan dan uitkomst bieden, omdat in dat model onzekerheden in gekwantificeerde vorm kunnen worden gehanteerd. Dan moeten omvang en aard van de variabiliteit bekend zijn, en moeten preferenties via priorkansen worden gedefinieerd. Priorkansen vatten de mate van geloof in een bepaalde uitspraak samen in een kansverdeling (Lucas 2002: 28).

\section{Fundamentele onzekerheid}

Moeilijker wordt het wanneer de onzekerheden meer fundamenteel van aard zijn (zoals van het type 'onbepaaldheid' en 'onwetendheid'; vgl. Van Asselt 20oo, en zie uitgebreider over dit onderwerp hoofdstukken 4 en 5 van dit rapport). Dan kan het wetenschappelijke debat over de keuze van de meest plausibele theorie (en de daaraan te ontlenen beleidsaanbevelingen) niet op basis van empirische bevindingen plaatsvinden. Ook kan er sprake zijn van observational equivalence, waardoor er niet voldoende waarnemingen beschikbaar zijn om tussen twee concurrerende theorieën te kunnen discrimineren. Beide theorieën kunnen de waarnemingen verklaren, terwijl ze volledig verschillende beleidsingrepen kunnen impliceren. Idealiter zouden dan meer kennis en waarnemingen, bijvoorbeeld via experimenten verkregen, uitkomst moeten bieden. Maar dat laatste is lang niet altijd mogelijk, bijvoorbeeld als doelbewust experimenteren niet tot de mogelijkheden behoort en men is aangewezen op 'natuurlijke experimenten'. In dat geval blijft een ideologische kleuring de stellingnamen in het debat overheersen. Het impliceert dat het criterium van doeltreffendheid dan weinig kan bijdragen aan het verkrijgen van een maatschappelijk draagvlak voor het beleid. Bij de beleidsvorming rondom klimaatbeleid - waar de onzekerheden groot zijn kunnen welvaartsanalyse en kosten-batenanalyse dus slechts een beperkte bijdrage leveren. Zo concludeert Van den Bergh (2002) dat er vanuit een economisch-theoretisch denkkader geen verantwoorde uitspraken over een 'optimaal klimaatbeleid' kunnen worden gedaan. Daarom kan er zijns inziens het best worden geopteerd voor het voorzorgsbeginsel; andere conceptueel-economische bijdragen aan klimaatbeleid zijn wel mogelijk.

\section{Inrichting van het wetenschappelijke debat}

Bepaalde vormen van onzekerheid kunnen niet met wetenschappelijke kennis worden weggenomen (Wynne 1992; 2001). Dit kan bij de beleidsvorming problemen opleveren omdat er dan een verschil van mening kan ontstaan over de waardering van de onzekerheid (Hisschemöller et al. 1998). Verschillende inschattin- 
gen van onzekerheid worden ook in de hand gewerkt als er grote belangen op het spel staan (Functowicz en Ravetz 1990; 1992). Ook kan het zijn dat betrokken partijen wel van elkaar afhankelijk zijn voor de oplossing van het probleem, maar beleidsargumentaties hanteren die langs elkaar heen gaan (Van Eeten 1999).

Ook in het milieubeleid kan een onoverkomelijk gebrek aan empirisch materiaal aanleiding geven tot een scholenstrijd in het wetenschappelijke debat. In dat geval is het van belang het debat zodanig in te richten dat er geen wetenschappelijke stromingen op voorhand worden uitgesloten en dat wetenschappelijke reputaties worden ontleend aan wetenschapsinterne mechanismen van reputatieopbouw, en niet worden bepaald door de media of door politiek bevooroordeelde beleidsmakers. Op die grond moet er hoor en wederhoor plaatsvinden, zodat alle argumenten met wetenschappelijke reputatie op tafel kunnen komen. Zo kan men trachten te komen tot een toetsing van de verschillende uitgangspunten. Men moet dus voorkomen dat bepaalde argumenten die vanuit wetenschappelijk perspectief hout snijden, op voorhand vanwege ideologische vooringenomenheid worden weggedrukt. Anders gezegd: het criterium 'aanvaardbaarheid' moet men in dit deel van de analyse naar de achtergrond schuiven. De uitkomst van zo'n debat kan zijn dat de verschillende wetenschappelijk gefundeerde, maar onderling niet op een noemer te brengen opvattingen worden vertaald in verschillende handelingsperspectieven (WRR 1994a). Die kunnen vervolgens in de beleidsarena worden geïntroduceerd. Participatie in de vorm van het betrekken van maatschappelijke partijen, kan in deze omstandigheden een belangrijke bijdrage leveren als aanvullend mechanisme voor draagvlakvorming voor het beleid (Jasanoff 1990).

\subsubsection{HET BELANG VAN PARTICIPATIE EN INTERACTIE}

\section{Participatie en (on)aanvaardbaarheid}

Participatie en interactie spelen een belangrijke rol als bron van draagvlakvorming voor beleid. Meningsvorming vindt immers niet alleen in het parlement plaats. Net als kennis en informatie speelt participatie verschillende rollen in de verschillende fasen van het beleid. De inbreng van maatschappelijke partijen kan, zoals de laatste decennia in het milieubeleid vaak het geval is geweest, aanleiding vormen voor besluitvorming doordat duidelijk wordt gemaakt dat bepaalde situaties onaanvaardbaar zijn. Dit kan bijdragen aan een algemene discussie over de aanvaardbaarheid van beleid en burgerparticipatie (denk aan de 'brede maatschappelijke discussie' over kernenergie en recent over biotechnologie), waarbij in geval van grote kennisonzekerheid wellicht toch tot overeenstemming kan worden gekomen; overeenstemming die voor een belangrijk deel een procedurele benadering betreft. Participatie kan daarnaast ook een veel concretere vorm krijgen, waarbij alleen de direct betrokkenen bij de uitvoering van het beoogde beleid worden betrokken. Zij kan verder bijdragen aan meningsvorming, en ook tijdens de uitvoering kunnen participatie en interactie bijdragen aan een goed verloop ervan. 


\section{Deliberatieve democratie als alternatief?}

Het belang van participatie bij de legitimering van het overheidsbeleid krijgt de laatste decennia veel aandacht (Held 1996: 263-273). Een uitgangspunt hierbij is dat de toenemende kritiek op de welvaartsstaat van de laatste decennia te wijten zou zijn aan het overheersen van een instrumentele rationaliteit en van objectivisme in politieke instituties en beleid. Dit zou geleid hebben tot een verarming van de politiek en tot een te groot vertrouwen in de technocratie van expertculturen (Beck 1992). In die optiek wordt daarmee onvoldoende recht gedaan aan de pluriformiteit van oriëntaties in de maatschappij, en de ermee samenhangende verschillen in de inschatting van haalbaarheid en aanvaardbaarheid van beleid. Met name geldt dit voor een aantal moeilijke milieuproblemen waarbij de onzekerheid over causale relaties groot is. Als recept voor dit veronderstelde tekort wordt er door een beleidswetenschappelijke stroming gepleit voor het ontwikkelen van een 'deliberatieve' of 'discursieve' democratie (Dryzek 1990; Elster 1998). Politieke participatie, actief burgerschap en maatschappelijk overleg worden daarbij opgevoerd als alternatief voor de gehekelde expertbenadering van beleid.

Wie daarentegen van alles het goede wil behouden, zal deze benadering eerder zien als een aanvulling op dan als een substituut voor de bewezen stramienen van politieke democratie en wetenschappelijke kennis. Wel agendeert de benadering enkele concrete problemen die momenteel indringend aan de orde zijn, zoals met name het (technocratische karakter van het) besluitvormingsproces in de (vergrote) EU en het democratisch deficit daarbij (vgl. Vaubel 2002).

Hiervoor is al geconstateerd dat participatie en interactie als mechanismen van draagvlakvorming voor beleid breed moeten worden opgevat. Zoals in paragraaf 3.2 is aangegeven, kunnen daarbij de criteria van haalbaarheid en aanvaardbaarheid dicht bij elkaar komen te liggen. Verder speelt participatie een verschillende rol in de verschillende fasen van het besluitvormingsproces. In die constateringen ligt eveneens het beginpunt verscholen voor een problematisering van specifieke vragen rond participatie. Als participatie bij verschillende functies en fasen verschillende rollen speelt, dan moet wellicht ook de vormgeving van participatie verschillen.

In dit kader heeft de raad in het verleden met betrekking tot de besluitvorming over grote infrastructurele projecten geadviseerd om het besluitvormingsproces 'op te knippen' in een aantal duidelijk afgebakende fasen die met duidelijke besluiten worden afgesloten. Daarbij moeten de vormgeving van de participatie en de keuze van de betrokken participanten op de desbetreffende fase aansluiten (WRR 1994b). Dit voorstel liet een tweede vraagstuk rond de organisatie van participatie onverlet. Het is namelijk een cruciale vraag wie er bij participatie wordt betrokken. Niet voor niets wordt er meer dan eens een strijd gevoerd om aan te mogen schuiven aan de onderhandelingstafel. Hier kan zich een probleem voordoen rond de invulling van rechtmatigheid als voorwaarde bij de legitimering van beleid. Waar namelijk de besluitvorming wordt beheerst door een beperkt aantal betrokkenen is het altijd de vraag in hoeverre de uitkomsten 
aansluiten bij het algemeen belang. In hoeverre kan zo ook de stem van nietaanwezige derde-belanghebbenden (die juist ook bij milieuhandelen betrokken zijn, bijvoorbeeld toekomstige generaties) voldoende tot zijn recht komen? Dit aspect van rechtmatigheid raakt ook aan de rol van participatie bij kennisverwerving. Immers, enerzijds dient de organisatie van de participatie gebaseerd te zijn op kennis over wie de belanghebbenden bij het milieubeleid zijn en waar de eventuele, op eigendomsrechten gebaseerde, belangentegenstellingen liggen. Anderzijds kan via een geschikte organisatie van de participatie kennis worden verworven over de preferenties (en hun relatieve gewicht) die aan de belangen ten grondslag liggen. Verder kan door participatie en articulatie van preferenties tot een gemeenschappelijke opvatting over het belang van milieubeleid worden gekomen, waarmee aan de aanvaardbaarheid van dat beleid wordt bijgedragen. Hiervoor is al benadrukt dat participatie, naast deze rol van het tot uitdrukking brengen van preferenties, ook andere rollen vervult.

\subsubsection{DILEMMA'S ROND ARRANGEMENTEN VAN MILIEUBELEID}

De laatste decennia heeft er een schaalvergroting plaatsgevonden van de onderkende milieuproblemen. Daarmee heeft ook een verschuiving plaatsgehad naar hogere bestuurlijke schalen waarop deze problemen tegemoet worden getreden. Waar het beleid in de jaren zeventig nog vooral lokaal, regionaal en nationaal was, ligt de nadruk inmiddels steeds meer bij Europese regelgeving en internationale afspraken. En waar de 'groene' problemen vooral in de nationale context zijn gereguleerd, daar geldt voor de wicked milieuproblemen dat de nadruk op Europese en internationale besluitvorming ligt. Met deze verschillende besluitvormingscontexten verschillen ook de beleidsarrangementen - de manier waarop kennis en participatie zijn ingebed in de democratische besluitvorming - sterk in de mate waarin de milieuproblemen worden aangepakt. De kenmerken van de Nederlandse besluitvorming en uitvoering verschillen van die van andere landen. In de Verenigde Staten volgt men vooral een juridische benadering bij de beleidsvorming en in het Verenigd Koninkrijk heeft lange tijd een 'elitistische' benadering de overhand gehad; de Nederlandse besluitvorming is meer participatief, conform de Nederlandse tradities (Jasanoff 1986; 1991). De vertaling van Europese of andere internationale regels naar nationaal beleid impliceert weer een ander besluitvormingsproces dan beleid dat louter in de nationale context tot stand is gekomen.

Deze verschillen moeten een belangrijke rol spelen bij een analyse van de legitimering van het milieubeleid van het komende decennium. Met de verschillen tussen de arrangementen verschillen immers wellicht ook de mogelijkheden om tot een goed beleid te komen. Ook de wijze waarop de legitimering plaatsvindt, en de eigen problemen die zich daarbij voordoen, variëren daarmee. Hoe verloopt dus de legitimering van het milieubeleid in de verschillende contexten? Hoe worden hierbij kennis en participatie ingezet om te komen tot beleid dat voldoet aan de vier eerdergenoemde voorwaarden voor goed beleid? Welke problemen kunnen worden gesignaleerd rond de aanpak van toekomstige problemen in een 
veranderende wereld? En welke antwoorden zijn hiervoor beschikbaar? De beantwoording van deze vragen vergt dat in het vervolg een onderscheid wordt gemaakt tussen drie arrangementen: nationaal beleid, Europees beleid en overig internationaal beleid. De mogelijkheden om in deze arrangementen tot succesvol beleid te komen, stellen mogelijk andere eisen aan de vormgeving van het milieubeleid. En de dilemma's die daarbij tegemoet moeten worden getreden, komen slechts vanuit de kenmerken van deze specifieke settings in beeld.

De vraag bij de analyse van de inzet van kennis en participatie is dus hoe overeenstemming ontstaat. Hoe wordt er beslist over de vraag welk beleid rechtmatig, doeltreffend en doelmatig, haalbaar en aanvaardbaar is? Belangrijke nevenvragen hierbij zijn de vraag hoe wordt omgegaan met onzekerheden over de aard van problemen en wenselijke oplossingen, en hoe wordt voorkomen dat die onzekerheden leiden tot blokkades in de besluitvorming. Bij de pogingen om hiermee om te gaan, ontstaan in verschillende beleidsarrangementen steeds eigen problemen. Om bij het nationale beleid te beginnen: hoe is hier onder omstandigheden van onzekerheid toch een min of meer succesvol beleid totstandgekomen? Hoe is er bemiddeld tussen de verschillende voorwaarden voor beleid? Welke bijdragen hebben kennis en participatie hierbij gespeeld, in aanvulling op de parlementaire democratie? En in hoeverre komt het beleid dat hiervan de uitkomst is in de komende decennia door maatschappelijke veranderingen mogelijk toch onder druk te staan? Wat is in het bijzonder de verhouding tussen het Nederlandse beleid en de diverse Europese regels?

Ten aanzien van het Europese 'arrangement' komen deels dezelfde, maar deels ook andere vragen in beeld. Hier gaat het in de eerste plaats om de vraag of en hoe men tot gelegitimeerd beleid komt. Ook hier is het de vraag hoe kennis en participatie, in aanvulling op de democratische parlementaire besluitvorming, worden ingezet. Hoe worden hier blokkades voorkomen? Verder komt hier een aantal specifieke vragen in beeld: hoe verhoudt zich de totstandkoming van het beleid op het Europese niveau en de uitvoering van dat beleid binnen de nationale context? Lukt het om bij de totstandkoming van het Europese beleid voldoende rekening te houden met de lokale kenmerken die bij de uitvoering belangrijk zijn? Hoe wordt het Europese beleid nationaal vertaald en (hoe) verschilt de Nederlandse uitvoeringspraktijk van andere landen? Ontstaat er, met andere woorden, een spanning tussen de haalbaarheid van het beleid op nationale schaal enerzijds en de doeltreffendheid en aanvaardbaarheid anderzijds? Ontstaan er door de afstand tussen beleidsvorming en uitvoering additionele problemen?

Tot slot kunnen ook ten aanzien van de internationale besluitvormingsconstellaties vragen worden gesteld. Komt men hier sowieso tot betekenisvolle afspraken? En hoe komen die dan tot stand? Welke rol spelen kennis en participatie hier bij pogingen om tot overeenkomsten te komen die aan de vier voorwaarden voldoen? En hoe kan de uitvoering van de afspraken worden gegarandeerd? Juist hier kan immers de in paragraaf 3.3 geschetste spanning, waarbij de directe relatie tussen abstracte langetermijnproblemen en ingrijpende gedragsveranderingen, 
voor problemen zorgen. Met het stellen van deze vragen zijn nu de contouren voor empirische analyses geschetst.

\subsection{NAAR EEN EMPIRISCHE ANALYSE}

De vragen ten aanzien van de spanningen om in de verschillende arrangementen tot beleid te komen dat voldoet aan de vier voorwaarden, laten zich het beste aan de hand van empirisch onderzoek behandelen. Die behandeling vindt plaats in hoofdstuk 4, tegen de achtergrond van de schets van de ontwikkeling van het milieubeleid uit hoofdstuk 2. Er komen zes casussen aan de orde rond specifieke milieuproblemen die de afgelopen decennia veel aandacht hebben getrokken. De analyse van deze casussen is geordend naar de verschillende arrangementen zodat de in paragraaf 3.4.4 gestelde vragen kunnen worden beantwoord.

Ten aanzien van het nationale beleid wordt de besluitvorming inzake hinderproblemen rond respectievelijk Rijnmond en Schiphol geanalyseerd. Hoe is die verlopen? Wat zijn de kenmerken van de Nederlandse aanpak? Hoe zijn hier de verschillende bronnen voor legitimering in de democratische context ingezet? Wat zal de invloed zijn van maatschappelijke en bestuurlijke veranderingen in de komende jaren? Ten aanzien van het Europese beleid komen de casussen over de Vogelrichtlijn en de Nitraatrichtlijn aan de orde. Hoe komt hier beleid tot stand dat aan de vier voorwaarden voldoet? Hoe wordt dit beleid in de Europese context gelegitimeerd? Wordt er voldoende rekening gehouden met de uitvoering op nationaal niveau en de discrepanties die dit kan geven? Hoe verhoudt de vertaling van de Europese regels in Nederland zich tot die in andere landen? Tot slot analyseren we twee problemen op mondiaal niveau, waarbij de onzekerheden bij uitstek groot zijn: de casussen klimaatverandering en chloormicro's. Lukt het rond deze casussen sowieso om tot betekenisvol beleid te komen? Leidt onzekerheid niet tot blokkades? En wat zijn vervolgens de uitvoeringskansen?

Steeds staat in de casussen de manier centraal waarop in de loop van de tijd langs de verschillende bronnen legitimering is verworven in termen van de vier voorwaarden voor beleid. Deze casusanalyses geven reliëf aan de beschrijving van de ontwikkeling van het milieubeleid uit hoofdstuk 2. Zij bieden geen basis voor een causale verklaring van het succes of falen van het (milieu)beleid in het algemeen. Wel geven zij inzicht in de manier waarop via de mechanismen kennis en participatie in verschillende besluitvormingscontexten is gezocht naar beleid dat voldoet aan de vier voorwaarden, en in de manier waarop wordt omgegaan met de in paragraaf 3.3 gesignaleerde spanningsvelden. 
NOTEN

$1 \quad$ Problemen rond lokale overlast en hinder bestaan al minstens een eeuw of vier; denk aan de lakenververs die de bierbrouwers in de weg zaten bij het gebruik van het stedelijke grachtenwater (zie bijv. De Bont 200o). 


\section{PRAKTIJKEN VAN BELEIDSVORMING}

\subsection{INLEIDING}

Tegen de achtergrond van de schets van de hoofdlijnen van de ontwikkeling van het milieubeleid in hoofdstuk 2 en met gebruikmaking van het analytische gereedschap en het evaluatieve kader van hoofdstuk 3, maakt het onderhavige hoofdstuk inzichtelijk op welke wijze in Nederland in concreto is en wordt getracht tot beleidsoplossingen te komen en in welke mate dat is gelukt. De aard van deze vraagstelling vergt met name aandacht voor de dynamiek, dat wil zeggen het gehele proces van probleemsignalering naar uiteindelijk probleemoplossing (voorzover hiervan kan worden gesproken). Ook gaat de aandacht uit naar de antwoorden die zijn of worden gegeven op de vier in hoofdstuk 3 genoemde kernvragen van beleid: aanvaardbaarheid, haalbaarheid, doelmatigheid en doeltreffendheid, en rechtmatigheid. Hiertoe wordt ingegaan op de wijze waarop in zes gevallen is gepoogd via de inbreng van wetenschappelijke kennis en maatschappelijke participatie, een goed milieubeleid te voeren. Het gaat daarbij om de casussen:

1 luchtverontreiniging Rijnmond;

2 Schiphol;

3 de Europese Vogelrichtlijn;

4 de Europese Nitraatrichtlijn;

5 klimaatverandering;

6 chloorhoudende verbindingen.

De casussen zijn nader beschreven en gedocumenteerd in het WRR-werkdocument Milieubeleid in een veranderende context: zes voorbeelden (WRR 2003b).

Deze casussen zijn gegroepeerd in drie categorieën:

- casussen met een overwegend nationaal beleidskarakter (de casussen 1 en 2);

- casussen met een Europees karakter en waarin de nationale en internationale beleidsaspecten onderling zijn verweven (de casussen 3 en 4);

- casussen die met een hoge mate van onzekerheid zijn omgeven en waarvan de probleemoplossing ingrijpende gedragsveranderingen vergt (de casussen 5 en 6).

Deze indeling is een logisch gevolg van twee centrale kenmerken van de hedendaagse milieuproblematiek: internationalisering van beleid en toenemende onzekerheden. In de vorige hoofdstukken werd de ontgrenzing van het milieubeleid als een cruciale ontwikkeling aangemerkt. Er is sprake van een verschuiving van zuiver nationaal beleid naar een steeds grotere bemoeienis van bovennationale jurisdicties, waarvan de EU de meest prominente is. Bij de casus over luchtverontreiniging in Rijnmond gaat het om autonoom totstandgekomen nationaal beleid (zij het dat hier inmiddels ook EU-regelgeving van toepassing is). Bij Schiphol is de nationale jurisdictie nog steeds dominant, maar bij de huidige besluitvorming spelen Europese normering, internationale luchtvaartverdragen en internationale regels op het gebied van veiligheid en geluidsbelasting al een 
rol. Europese normering speelt een dominante rol bij de tweede categorie, die bestaat uit de Nitraat- en Vogelrichtlijn van de EU. Beide richtlijnen leggen aan Nederland beleid op dat het voorheen bestaande nationale beleid aanvult of vervangt, en betekenen in elk geval een aanscherping daarvan. De klimaatproblematiek speelt op boven-EU-niveau, zij het dat de Unie hier wel degelijk een belangrijke intermediaire rol speelt. Het Kyoto-Protocol betreft immers een internationaal verdrag waarbij de EU partij is.

Lopen derhalve de twee eerste categorieën sterk uiteen naar de mate van vervlechting tussen de nationale en bovennationale jurisdictie, de derde categorie betreft milieuproblemen met een hoge mate van onzekerheid en geringe kenbaarheid. Hier speelt derhalve vooral het onderscheid dat de OESO maakte tussen enerzijds 'groene' en anderzijds 'oranje' en 'rode' kwesties. In de derde categorie staan de - overigens niet scherp te onderscheiden - oranje en rode problemen centraal: ingrijpende en hardnekkige milieuvraagstukken, waarover relatief grote onzekerheden bestaan dan wel problemen waarvan de oplossing vanwege ingrijpende consequenties stagneert. Juist bij deze problemen zijn de legitimeringvraagstukken voor het beleid buitengewoon complex en is de beleidsontwikkeling steeds een controversiële aangelegenheid.

De gekozen driedeling illustreert ook andere verschillen dan onzekerheid en de mate waarin bovennationale jurisdicties interveniëren in het nationale beleid. De termijn waarop de milieuproblematiek zich manifesteert en de kenbaarheid ervan lopen sterk uiteen. Luchtverontreiniging en geluid zijn in principe direct en lokaal door gelaedeerden waarneembaar. Dat ligt al veel lastiger bij de grondwaterkwaliteit en ontwikkelingen in de vogelstand. Bovendien is de relatie tussen oorzaak en gevolg moeilijker, ook vanwege het tijdsverloop tussen beide. Waarneming en interpretatie vergen hier een veel sterkere tussenkomst door de wetenschap. Dat geldt bij uitstek voor microverontreinigingen door de talloze chloorverbindingen en het vraagstuk van klimaatverandering. In zoverre staan de twee laatste model voor de meest complexe milieuproblemen. Voor een juiste signalering van deze problemen is men volledig aangewezen op het gezag van de wetenschap, terwijl bij luchtverontreiniging en geluid de wetenschappelijke analyse en problematisering aansluiten op de probleemsignalering door direct betrokkenen.

De drie categorieën lopen, zoals gezegd, ook sterk uiteen wat de gepercipieerde oplossingen betreft. Het voorkómen van klimaatverandering vergt vermoedelijk van zeer velen ingrijpende gedragsaanpassingen in de productieve en consumptieve sfeer. Hieraan afgemeten zijn de aanpassingen in de eerste en tweede categorie veel beperkter en betreffen zij bovendien kleinere groepen van betrokken actoren. Het voeren van beleid ten aanzien van een probleem dat er nog niet is, een hoge mate van onzekerheid kent, van velen ingrijpende gedragsaanpassingen vergt, en waarvan het succes zich uit in het zich niet voordoen van het probleem op een termijn die buiten het gezichtsveld valt van de dragers van de kosten, trekt een zeer sterke wissel op het bestuurlijke vermogen om tot adequaat handelen te komen. 
De hier gehanteerde selectie van te beschouwen casussen illustreert de veelkoppigheid van het milieubeleid. 'Het milieu' kan derhalve geacht worden in het geding te zijn in zeer uiteenlopende gevallen, namelijk zowel wanneer er sprake is van hinder door menselijke activiteit voor mensen zelf als wanneer menselijke activiteit gevolgen heeft voor plant- en diersoorten. Dit containerkarakter van milieubeleid bemoeilijkt een onderlinge vergelijkbaarheid van de casussen. Het gaat in dit hoofdstuk dan ook niet om de merites van de casussen op zichzelf, maar steeds om de vraag op welke wijze antwoord wordt gezocht op de vier kernvragen voor goed beleid en de mechanismen die worden ingezet om tot acceptabele antwoorden te komen. Bovendien geldt voor alle gevallen dat er sprake is van een noodzaak tot het accommoderen aan nieuwe schaarsten (lucht, water, stilte, klimaat, natuurwaarden, e.d.). Dit noopt - in welvaartstheoretische terminologie - tot het vaststellen en toedelen van private en publieke eigendomsrechten (grandfathering). Iedere beleidsregulering, bijvoorbeeld de normering van de geluidsproductie van vliegtuigen, legt eigendomsrechten vast, en is hiermee bepalend voor de ruilwaarden en relatieve onderhandelingsposities (zie bijv. Bovenberg en Teulings 1999). Zoals zal blijken, is deze vaststelling en toedeling in geen van de casussen een eenvoudige aangelegenheid; steeds worden immers 'oude' rechten aangetast.

In de paragrafen 4.2 tot en met 4.4 volgt een beschrijving van de drie categorieën beleidsproblemen. Daarbij is gebruikgemaakt van het gelijk met dit rapport gepubliceerde WRR-werkdocument Milieubeleid in een veranderende context: zes voorbeelden, waarin de zes casussen uitvoerig zijn gedocumenteerd. Paragraaf 4.5 trekt een aantal lessen uit het gepresenteerde materiaal en formuleert enkele vragen.

\subsection{HINDERPROBLEMEN: RIJNMONDEN SCHIPHOL}

\subsubsection{INLEIDING}

Rijnmond en Schiphol zijn niet alleen belangrijk voor de Nederlandse economie, maar veroorzaken ook veel hinder voor de lokale bevolking. Het gaat hierbij om een ruime groep belanghebbenden die een welvaartsvoordeel ontleent aan activiteiten waar een veel beperktere groep veel hinder van ondervindt. Beide casussen illustreren dan ook bij uitstek de problemen die zich voordoen als milieu en economie op gespannen voet staan. De belangen die in het geding zijn, zijn buitengewoon groot en geven zich derhalve niet op slag of stoot gewonnen. De afwezigheid van voor de hand liggende win-win-oplossingen plaatst ook de betrokken overheden voor zeer lastige vraagstukken. Welvaartsvergroting en milieubescherming zijn beide geaccepteerde doelstellingen van beleid, maar het vinden van een acceptabele combinatie van deze doelstellingen die de grootste maatschappelijke welvaart oplevert, vormt geen dankbare taak. Onvermijdelijk betekent zo'n maatschappelijk optimum immers dat alle betrokkenen iets van hun aanvankelijke individuele voorkeuren moeten inleveren. 


\subsubsection{LUCHTVERONTREINIGING IN RIJNMOND}

In retrospectief lijkt Rijnmond een voorbeeldige casus; er wordt thans nog weinig vernomen van enigerlei conflict rond de luchtverontreiniging. De kwestie is - in de termen van de OESO - een 'groen' probleem geworden. Bevredigend als de gevonden oplossingen vooralsnog mogen zijn, de geschiedenis ervan laat een turbulent en slepend verloop zien. Zij laat zien hoe 'het milieu' als strijdpunt in de samenleving is ontdekt, wat maatschappelijke (protest)acties hebben opgeleverd, en wat het publieke belang is geweest van de openbaarheid over negatieve externe effecten van bedrijfshandelen.

In de jaren voor 1960 maakte het milieu nog geen deel uit van het politieke en maatschappelijke discours. Economische productiegroei genoot absolute en vanzelfsprekende prioriteit; rokende schoorstenen waren immers een teken van vooruitgang en hiermee samenhangend ongerief werd voor lief genomen. Het toenmalige regime van de Hinderwet kende weliswaar beperkingen aan emissies door bedrijven, maar werd nauwelijks gehandhaafd.

De eerste indicaties voor een mogelijk probleem kwamen uit wetenschappelijke hoek: al in de vroege jaren zestig sloegen gezondheidsdeskundigen alarm en veldbiologisch onderzoek wees op verschraling van de natuur. De overheid hield zich niet geheel afzijdig; in de jaren zestig werden verschillende instellingen en commissies gevormd die zich met vervuiling bezighielden, zoals de Inspectie Milieuhygiëne (1962), de Commissie Bodem, Water en Lucht (1964), het initiatief tot oprichting van de Centrale Meld- en Regelkamer Luchtverontreiniging (CMRK) (1964) en de oprichting van het Openbaar Lichaam Rijnmond (OLR) (1965). Al deze instellingen hadden aanvankelijk weinig invloed, maar zij legden wel de institutionele basis voor de vormgeving van het latere beleid. Het waren echter vooral de vele incidenten (smogvorming, stankgolven, gifwolken, e.d.) rond 1970 die de apathie bij de bevolking en de laksheid van overheid en bedrijfsleven doorbraken en een brede mobilisatie bij de bevolking op gang brachten, vooral over gezondheidsproblemen als gevolg van emissies van de industrie. Vele omwonenden en actiegroepen speelden een belangrijke rol bij de bewustwording.

Een groot probleem vormde de afwezigheid van toereikende, betrouwbare en openbare informatie; er heerste grote onzekerheid over de aard van de luchtverontreiniging, en derhalve ook over de schadelijkheid ervan. Voorzover al (schaarse) informatie bestond, werd deze door het bedrijfsleven gemonopoliseerd en aan het betrokken publiek onthouden; van enigerlei publiek recht op informatie was nog geen sprake. Ook de overheid was voor de relevante informatie grotendeels aangewezen op het bedrijfsleven, en verliet zich daar aanvankelijk ook op. Door deze afwezigheid van onafhankelijke informatie bestond er alle ruimte voor ontkenning respectievelijk overschatting van het probleem. Het was dan ook geen wonder dat voor de probleemerkenning de aard, kwaliteit en openbaarheid van de informatie een belangrijke inzet van de strijd vormde. Veront- 
ruste omwonenden en actiegroepen troffen vaak een gesloten front van bedrijfsleven en overheid tegenover zich dat kwam met geruststellende of probleemontkennende informatie. Dit versterkte het wantrouwen en leidde tot het inzetten van contra-experts die tot tegengestelde bevindingen en oordelen kwamen. In de vele protestacties werd steevast een beroep gedaan op het recht op gezondheid en in mindere mate op een groene omgeving; ook het right to know en de verantwoordingsplicht van bedrijven en overheden was een belangrijke inzet van de acties. Hier tegenover werd aanvankelijk vooral gewezen op de noodzakelijke functie van Rijnmond voor de Nederlandse economie.

De grote behoefte aan onafhankelijke, betrouwbare en permanente monitoring leidde in 1967 tot het openen van een klachtenlijn en in 1969 tot het instellen van het eerste geautomatiseerde meetnet in het Rijnmondgebied. In de jaren vijftig werden ook al metingen verricht door de Keuringsdienst voor Waren te Rotterdam, maar deze betroffen globale metingen naar verontreinigingen in de buitenlucht (Hazewinkel 1997: 70). In 1974 werden de klachtenlijn en het meetnet ondergebracht bij de toen ingestelde Dienst Centraal Milieubeheer Rijnmond (DCMR), die de milieutaken uit de regio bundelde. De DCMR kreeg uitvoerende taken ten aanzien van vergunningverlening en handhaving en een adviserende bevoegdheid ten aanzien van door het bevoegd gezag af te geven beschikkingen. De klachtenlijn en de rapportages over de acties die bij klachten werden ondernomen, gaven burgers het gevoel dat zij serieus werden genomen: een vroeg voorbeeld van een 'responsieve overheid'. Hier droeg ongetwijfeld toe bij dat de DCMR niet werd verdacht van afhankelijkheid van een van de grote partijen. De dienst vormde een onderdeel van het OLR, dat als gewestelijk bestuur juist ook als taakstelling had een democratische buffer te vormen tussen Rotterdam en de randgemeenten. Het OLR werd in 1986 weer opgeheven, maar de DCMR werd in stand gehouden.

De combinatie van subjectieve probleemperceptie via de klachtenlijn en objectieve toetsing via het meetnet leidde ertoe dat het probleem niet langer kon worden ontkend of gebagatelliseerd. Naarmate er meer gegevens beschikbaar kwamen, werd de roep om maatregelen sterker. De publieke beschikbaarheid van de informatie zette de overheden dan ook aan tot een actief beleid. Dit resulteerde aanvankelijk in een serieuzer handhavingsbeleid ten aanzien van de Hinderwet, die in 1970 werd opgevolgd door de Wet op de luchtverontreiniging (in 1993 opgegaan in de Wet milieubeheer). In 1972 werd mede op instigatie van de DCMR het Rijnmondgebied aangewezen als saneringsgebied, resulterend in een gezamenlijk milieuactieplan van het bedrijfsleven. Die status kon in 1988 worden beëindigd. Het aantal klachten jegens het industriële bedrijfsleven nam sindsdien een ondergeschikte positie in.

De gehele reconstructieperiode, waarin het vooral ging om het verminderen van de negatieve invloed van de industriële bedrijvigheid op de volksgezondheid tot aanvaardbare niveaus, besloeg derhalve ruim twintig jaar. Eind jaren tachtig ten slotte volgde de toewijzing van de zogeheten 'ROM-status' aan het gebied. Deze 
status impliceerde een integrale benadering van ruimtelijke ordening en milieu. Voor Rijnmond ging het hierbij zowel om het versterken van de mainport als om de leefbaarheid. De discussie verplaatste zich derhalve van volksgezondheid naar ruimtelijke inrichtingsvraagstukken, waarbij nieuwe desiderata als 'rust en groen' hun intrede deden.

De discussie over de mate waarin deze in het gebied moeten en kunnen worden gerealiseerd, gaat nog voort en hangt ook samen met het vraagstuk van de Tweede Maasvlakte. Met de succesvolle afloop van de lokale luchtverontreiniging is de milieuproblematiek derhalve nog niet beëindigd. De sterke concentratie van bevolking en werkgelegenheid en de welvaartsstijging gaan bovendien niet alleen gepaard met een lokale behoefte aan een meer gevarieerde leefomgeving, maar draagt ook bij aan een sterke toename van het wegverkeer, en daarmee gepaard gaande geluidshinder en $\mathrm{CO}_{2}$-uitstoot. Met name het laatste probleem is veel weerbarstiger dan dat van de lokale luchtverontreiniging. In paragraaf 4.4 .2 wordt hierop verder ingegaan.

Deze casus laat een aantal zaken zien:

- Van de vier kernvragen van beleid blijkt in deze casus vooral die van de aanvaardbaarheid van doorslaggevend belang te zijn geweest. Cruciaal was dat de autoriteiten en de veroorzakers ervan doordrongen moesten worden dat er sprake was van een zorgwekkend probleem. Het totstandkomen van deze probleemerkenning vergde zeer veel actie van de lokale bevolking en hiertoe gevormde actiegroepen. De rechtmatigheid van de oplossingsrichting vormde hier nauwelijks inzet van conflict: de Hinderwet werd met voeten getreden en vrijwel niet gehandhaafd, zoals bij menige actie bleek. Toen eenmaal de principiële probleemerkenning een feit was, leidden de latere aanscherpingen in de nieuwe wetten, de voorschriften in het kader van het saneringsbeleid tot veel minder protest van de kant van het bedrijfsleven.

Frappant is geweest dat zich gaandeweg in de houding van het bedrijfsleven een kentering heeft voorgedaan. Niet alleen ging men geleidelijk nut en noodzaak inzien van openheid en communicatie in de richting van de overheid, maar er kwam zelfs een zekere competitie op gang in het vrijwillig tonen van 'goed milieugedrag' jegens de bevolking. Er trad derhalve een zekere internalisering van de milieuwaarde op, ongetwijfeld ook omdat duidelijk werd dat de milieuprestatie van belang was voor het bedrijfsimago. Het in de jaren negentig ingevoerde systeem van Bedrijfsinterne milieuzorg en de verplichting tot milieujaarverslagen hebben hier wellicht ook toe bijgedragen.

De toegenomen bereidheid zelf meer verantwoordelijkheid voor het milieu te nemen, blijkt ook uit de laatste jaren ontwikkelde overlegvormen voor bewoners en bedrijfsleven op wijkniveau die resulteren in afspraken. In 1997 opperde Shell het idee om - in navolging van Amerikaanse ervaringen - een 'sociale verblijfsvergunning' in te voeren: een door belangengroepen af te geven 'verklaring van goed gedrag' die betrekking heeft op gedrag dat uitgaat 
boven de eisen van de door de overheid gestelde milieueisen. Aan de haalbaarheid van de gekozen oplossingsrichting is in sterke mate bijgedragen door de institutionele structuur die voorhanden was toen de maatschappelijke druk tot kookhoogte steeg. De rol van het OLR representeerde de juiste schaal uit het oogpunt van die waarop het probleem zich voordeed. Hierdoor werd de dominantie van Rotterdam ingeperkt en konden de randgemeenten zich direct doen gelden. De responsiviteit van het OLR en de hieronder ressorterende DCMR leidde gaandeweg tot het verminderen van de onrust onder burgers; bovendien heeft de dcmr ook een gezaghebbende positie opgebouwd bij het bedrijfsleven. De effectiviteit van de gekozen beleidslijn is hierdoor sterk bevorderd. Deze laat zich in abstracto moeilijk beoordelen; twintig jaar voor de probleemoplossing is immers een lange periode. Bovendien gaat het hier - zoals gezegd - om een periode waarin het milieu als het ware werd uitgevonden, evenals het daaraan toe te kennen gewicht: een cultuuromslag niet alleen bij bevolking, politiek en overheden, maar ook bij het bedrijfsleven.

- De onafhankelijkheid van informatieverschaffing over de in het geding zijnde verschijnselen is van majeure betekenis. Zo ontstaat informatie waar de autoriteiten en veroorzakers niet omheen kunnen (via naming and shaming) en kan onjuiste informatie worden ontzenuwd. Ontbreekt adequate informatie, dan is er alle ruimte voor polarisatie, wantrouwen, geruchten, en dergelijke. Informatie die door belanghebbenden wordt verschaft, zal altijd door andere partijen verdacht kunnen worden van manipulatie. Het meetnet, alsook het aan de resultaten kunnen koppelen van een waarschuwingssysteem en sancties voor de veroorzakers, is cruciaal geweest voor het herstel van vertrouwen in de autoriteiten.

Naast onafhankelijkheid is ook openbaarheid van informatie essentieel. De jaren zestig en vroege jaren zeventig vormden de nadagen van een paternalistische vorm van bestuur, waarin het onthouden van informatie juist in het belang van de bevolking werd geacht. De casus laat bij uitstek zien hoezeer openbaarheid van informatie, ook als deze toont dat er negatieve gevolgen kunnen optreden, kalmerend kan werken, als de betrokken bevolking tenminste de overtuiging heeft van slagvaardig bestuurlijk optreden in reactie op de informatie.

- De casus laat ook zien dat maatschappelijke participatie belang is voor de beleidsontwikkeling. In ambtelijke kringen werden de milieuproblemen al in de vroege jaren zestig onderkend. Toch was het pas onder grote maatschappelijke druk dat de overlast als urgent werd onderkend en politiek en bestuur echt in beweging kwamen. Actiegroepen speelden een belangrijke rol in het doorbreken van de maatschappelijke apathie. Voor deze mobilisatie was niet alleen een probleembesef nodig, maar vooral ook een besef dat maatschappelijke actie tot resultaat kon leiden. In dit geval lag de oplossingsrichting voor de hand: de overheid diende voor alles de bestaande wet te handhaven. 


\subsubsection{SCHIPHOL}

De kwestie Schiphol is wat de hinderproblematiek betreft grotendeels een nationale en regionale beleidsaangelegenheid. Maar de maatschappelijke voordelen en de mogelijke beleidsoplossingen dragen veel meer een internationaal karakter dan de voorgaande casus. Zo speelt de regelgeving van de EU een rol, zijn de internationale verdragen voor landingsrechten en slotallocaties van belang en heeft de internationale regelgeving ten aanzien van vliegtuiglawaai invloed op de mate waarin de luchtvaart geluidsarmer wordt. Hiernaast is de ontwikkeling van Schiphol als hub direct afhankelijk van internationale samenwerkingsrelaties in de luchtvaart (allianties) en van de capaciteitsontwikkeling op de concurrerende hubs in Europa (Londen, Parijs en Frankfort).

De hinderproblematiek rond Schiphol is tot op zekere hoogte vergelijkbaar met die in Rijnmond. Ook hier staan economische en milieubelangen op gespannen voet. Evenals bij Rijnmond is het milieuprobleem (geluidhinder en stank) zintuiglijk goed waarneembaar en treft het vooral de lokale bevolking, terwijl het economische belang, namelijk de mogelijke bijdrage aan economische groei en werkgelegenheid, de lokale schaal aanzienlijk overtreft. Ook is er sprake van een langdurig toelaten door de overheid van overschrijding van de bestaande normstelling en heftige reacties hierop door bewoners en actiegroepen. Hierbij spelen niet alleen technische problemen rond de meetbaarheid en toenemende twijfel over de juistheid van de normen zelf een rol, maar ook het belang van Schiphol voor de nationale economie staat ter discussie. Evenals in Rijnmond vormt het op betrouwbare en onafhankelijke wijze vaststellen van normoverschrijdingen een belangrijk aspect van de controverses. Echter, bij Schiphol lopen de probleemdefinities verder uiteen en daarmee ook de voorgestane oplossingsrichtingen. Dat Schiphol een belangrijk milieuprobleem vertegenwoordigt, is duidelijk. De luchthaven heeft de afgelopen tien jaar een enorme groei doorgemaakt: het aantal passagiersbewegingen is verdubbeld en het aantal vliegtuigbewegingen is jaarlijks met ongeveer zes procent gegroeid, behalve in het jaar 2001. Voor de toekomst wordt een flinke doorgroei van de vraag naar luchtvaartdiensten verwacht, zeker wanneer Schiphol zijn plaats als knooppunt binnen het hub-andspoke-systeem zal behouden. Terwijl in Rijnmond de oplossingsrichting na de moeizame fase van de probleemaanvaarding eigenlijk wel heeft vastgestaan (de industrie moet zich aan de normen houden), zijn bij Schiphol de normen zelf onderdeel van het probleem en de te vinden oplossing, evenals hiermee samenhangend de ruimte die de luchthaven voor verdere expansie moet worden gegund (de 'nut en noodzaak'-discussie). Veel meer dan bij Rijnmond vormen rond Schiphol van meet af aan waardeconflicten en daarmee divergerende probleemdefinities en oplossingsrichtingen derhalve de inzet van de discussies. Gaat het in Rijnmond aanvankelijk voornamelijk om de gezondheidsproblematiek van de lokale bevolking en komen pas veel later de waarden 'rust' en 'groen' op, in de discussie rond Schiphol spelen deze laatste wenselijkheden tegelijk met waarden ten aanzien van gezondheid en veiligheid. 
Maar naast deze lokale en regionale aspecten speelt hier ook het veel algemenere vraagstuk van de richting van de economische ontwikkeling in Nederland een rol. 'Schiphol' is zo het vehikel geworden voor een discussie tussen twee denkwerelden. Tegenover het gedachtegoed dat pleit voor 'Nederland als distributieland', 'Schiphol als mainport', 'economische groei', 'negatieve milieueffecten binnen grenzen', 'alternatieve luchthavenlocaties' staat het gedachtegoed van 'Nederland als kennisland', 'Schiphol voor eigen mobiliteit', 'selectieve economische groei (rust, ruimte en duurzaamheid)', 'actieve bescherming van natuur en milieu', 'geen alternatieve luchthavenlocaties want die verplaatsen het probleem alleen maar' (Abma 2001). Deze twee scherp tegenover elkaar staande denkstructuren zijn nog niet verdwenen. Wel is een alternatieve locatie (zoals Flyland) door het kabinet-Kok vooral vanwege de enorme kosten (en vanwege mogelijke problemen met trekvogels) vooralsnog als een serieuze optie terzijde geschoven. Desondanks blijft Flyland voor de lange termijn een optie en is het onderzoek naar de haalbaarheid niet volledig stopgezet. Maar de discussie concentreert zich nu toch in eerste instantie op de huidige locatie.

De casus valt uiteen in drie onderdelen: het normenstelsel en het meetsysteem hiervoor, de ingebruikneming van de vijfde baan in 2003, en eventuele verdere capaciteitsuitbreidingen voor de langere termijn (van 2010 tot 2030). Hier doorheen speelt bovendien de kwestie van de privatisering van de luchthaven.

Aanvankelijk gold een normensysteem dat naast de geluidsproductie ook het aantal vliegbewegingen en aantallen passagiers limiteerde. Met name beide laatste middelvoorschriften (als indirecte benadering van de belasting: zgn. proxies) vormden een ernstige belemmering voor de expansiemogelijkheden van de sector. Ze legden Schiphol een keurslijf op, omdat zo technische verbeteringen (geluidsarmere vliegtuigen, andere aanvlieg- en startprocedures) niet konden worden gecompenseerd met meer vliegbewegingen. Het lag dan ook voor de hand om uitsluitend milieunormen (geluid, vervuiling en veiligheid) te hanteren, waarbinnen Schiphol een eigen bedrijfsvoering mocht verrichten en daarmee expansiemogelijkheden behield. Eind 1999 besloot het kabinet dat Schiphol 'beheerst' mocht groeien op de huidige locatie mits zou worden voldaan aan nieuwe milieunormen. Overtreding van grenswaarden zou voortaan niet worden getolereerd. Dit besluit doorbrak de impasse die was gegroeid door het regelmatig gedogen van normoverschrijdingen, het aan de kaak stellen hiervan door de milieubeweging en het voortduren van het verschil van inzicht over de toekomst van de luchthaven. Hieraan vooraf gingen, vooral in de tweede helft van de jaren negentig, verschillende pogingen om de verschillende stakeholders op een lijn te krijgen. De in 1997 gestarte 'nut en noodzaak'-discussie over de groei van de luchtvaart in Nederland - een poging om een dialoog op gang te brengen - resulteerde niet in de beoogde consensus. In 1998 werd het TOPS-beraad (Tijdelijk Overleg Platform Schiphol) ingesteld, waarmee werd gehoopt de stakeholders (sector, bedrijfsleven, milieubeweging, bewoners, lokale en provinciale overheden) tot overeenstemming te laten komen over een nieuw stelsel van milieunormen dat beter handhaafbaar was dan het oude systeem. Hoewel men het in prin- 
cipe eens werd over het uitgangspunt dat Schiphol als een gewoon bedrijf moest worden gezien dat zelf moest kunnen bepalen op welke wijze men aan door de overheid te stellen milieunormen voldeed, stapten Milieudefensie en Milieu en Natuur een jaar later toch uit het platform. Volgens de milieubeweging voerde de sector tegen de afspraken in eigenstandig gesprekken met het ministerie van Verkeer en Waterstaat, terwijl het TOPS-overleg nog gaande was (De Volkskrant, 25 november 1999). Desalniettemin nam het kabinet genoemd besluit en werd een jaar later Schiphol inderdaad beboet wegens normoverschrijding.

Op zich heeft dit besluit inderdaad meer transparantie in de afweging tussen milieubelasting en economisch welvaartsvoordeel gebracht. Normen over aantallen vluchtbewegingen en aantallen passagiers zijn immers betrekkelijk irrelevant als indicatoren voor milieubelasting. Voorzover het de geluidsbelasting betreft, gaat het uiteindelijk om de totale hoeveelheid geluid die Schiphol bij zijn bedrijfsvoering produceert. Toch zitten bij de normstelling van dit externe effect twee adders onder het gras die 'sluiting' van deze casus verhinderen. In de eerste plaats is de bepaling van de totale hoeveelheid geluid en de geografische en intertemporele spreiding daarvan met meer 'mitsen en maren' omgeven dan men op het eerste gezicht zou denken. Ten tweede wordt met het aangeven van de maximaal te produceren hoeveelheid geluid impliciet een verdeling van de eigendomsrechten op het maken van geluid (of op stilte) tussen omwonenden en luchthaven vastgesteld. Hiermee is het verdelingsprobleem niet opgelost, enerzijds omdat de verdeling van de geluidsoverlast zich bij verandering van baanconfiguraties kan wijzigen, en anderzijds omdat met een vast geluidsplafond de mogelijkheid van een welvaartsafruil tussen geluidsoverlast en economisch gewin wordt uitgesloten.

De Schiphol-casus is een voorbeeld bij uitstek van de merites van het multiactormodel. Er waren vele actoren en belanghebbenden bij de discussie betrokken: luchthaven, luchtvaartmaatschappijen, lokale bewoners, werkgevers, werknemers, milieubeweging, natuurbeweging, nationale, regionale en lokale overheid en de politiek op verschillende niveaus. De politiek hield zich aanvankelijk op afstand en hoopte dat discussies en dialogen consensus zouden opleveren. Deze gedachte was nogal naïef, aangezien er sprake was van grote belangentegenstellingen, en de belangen en de hierbij impliciete toedeling van eigendomsrechten door de overheid niet eens goed werden onderkend. De agenda's van alle betrokken gremia liepen uiteen, en stonden soms zelfs diametraal tegenover elkaar: zie de eerdergenoemde twee denkstructuren. Betrokkenen bestookten elkaar ook vaak met eigen onderzoek, waarvan de resultaten soms ver uiteenliepen. Dat in zo'n situatie de verhoopte consensus onbereikbaar bleek, wekte weinig verbazing. Het sluiten van compromissen werd onvermijdelijk, waarbij tevens de eigendomsrechten op een goede manier werden omschreven. Bij uitstek stelde zich de vraag naar de verantwoordelijkheidsverdeling: welke actor was de rechtmatige vertegenwoordiger van welk belang en wat waren ieders competenties? Samenhangend hiermee was de vraag naar de selectie van de stakes. In de praktijk van deze casus was er geen selector; degenen die zich 
opwierpen als vertegenwoordiger van enigerlei belang, konden aan tafel aanschuiven. In een zuivere toepassing van het multi-actormodel zouden alle belangen moeten zijn vertegenwoordigd, maar wie behartigde bijvoorbeeld het belang van de consument van luchtvaartdiensten? Deze kende geen directe vertegenwoordiging in het TOPS-overleg. Later, in de studie van het Centraal Planbureau naar de maatschappelijke kosten en baten op grond van kengetallen, zou blijken dat juist deze partij de grootste welvaartsvoordelen bij capaciteitsuitbreiding zou hebben (Koning et al. 2002). Andere belangen, zoals van specifieke werkgelegenheid in de luchtvaart, natuur en milieu, waren echter wel door de desbetreffende nationale instellingen vertegenwoordigd. In ieder geval had de overheid hier in het participatieproces een veel sterkere en meer proactieve regie kunnen voeren om een indruk te krijgen van de voorkeuren en belangen van de verschillende stakes, waarbij tevens in een eerder stadium de confrontatie en afweging van deze belangen in een welvaartsanalyse had kunnen plaatsvinden.

Wellicht had bij een dergelijke regie het multi-actormodel goed kunnen functioneren om te komen tot een goede articulatie van de verschillende gezichtspunten, van de waarden die in het geding waren, van een onderzoeksagenda over betwiste zaken en van de marges waarbinnen een oplossing denkbaar was. Het zou daarbij vooral om de fase van probleemsignalering en die van verkenning van denkbare opties zijn gegaan. Maar omdat een multiple win-situatie niet voor het grijpen lag en compromisvorming onvermijdelijk was, was dat model voor de fase van besluitvorming minder bruikbaar. Voor de overheid was toepassing van het multi-actormodel juist in die vroegere fase van belang. Langs die weg zou zij de noodzakelijke informatie bijeen kunnen brengen om de aanvaardbaarheid, haalbaarheid en ex ante zicht op effectiviteit van mogelijke oplossingen te vergroten. Maar omdat besluitneming in deze situatie niet viel te verwachten, was het toch aan de nationale overheid die rol te vervullen, 'gehoord alle partijen'. Dit gold temeer waar de problematiek niet van zuiver lokale aard was, maar was verweven met tal van nationale, publieke belangen.

De twee hiervoor aangehaalde redeneerlijnen laten ook zien hoe lastig het soms is de vier criteria voor goed beleid in de praktijk van elkaar te onderscheiden. $\mathrm{Zij}$ hadden in de Schiphol-casus eerder betrekking op het proces van menings- en besluitvorming dan op de einduitkomst. De regering probeerde, terwille van de effectiviteit en het verkrijgen van maatschappelijk draagvlak (aanvaardbaarheid), de kluwen aan probleemdefinities en voorgestane oplossingen te ontrafelen. $\mathrm{Zij}$ trachtte het proces te trechteren door deze kluwen te ontleden in een aantal fasen. Deze pogingen hadden zeker voortgang tot gevolg. Belangrijk hierbij was het initiatief om de milieubeweging terwille van de haalbaarheid te committeren aan deze fasering, onder andere door haar op te nemen in het Tops-beraad. De aanvankelijke aanvaarding door de milieubeweging van de termen van het TOPSoverleg (loslaten van limitering van het aantal vliegbewegingen, en concentratie op milieunormering) vormde een belangrijke concessie ten aanzien van de gehanteerde probleemdefinitie. Deze impliceerde immers dat zij in principe haar uitgangspunt 'Schiphol voor eigen mobiliteit' moest laten varen en voortgaande 
groei als mainport moest aanvaarden voorzover die althans verenigbaar zou zijn met de nieuwe milieugrenzen. Deze consequentie zou haar bewegingsvrijheid ten aanzien van de volgende fasen (vijfde baan en eventueel volgende) aanzienlijk inperken. Men kan dit overigens ook nog anders zien: met het eerdergenoemde regeringsbesluit de groei van Schiphol te binden aan uitsluitend milieunormen en de limieten voor vliegbewegingen en aantallen passagiers te schrappen, werd Schiphol tegelijk ontdaan van de zware last het vehikel te zijn voor een discussie over de ontwikkeling van milieu en economie in brede zin, zoals tot uiting kwam in de twee genoemde brede ontwikkelingsparadigma's. De discussie verschoof zo van absoluut naar relatief niveau: van eerst voor of tegen groei kwam nu de wenselijke mate van groei voorop te staan. Het milieuvraagstuk werd hierdoor tegelijk teruggebracht naar lokaal niveau: welke mate van lawaai en stank achtte men acceptabel? Deze belangrijke doorbraak maakte in principe besluitvorming mogelijk via de bewandelde multi-actorweg. Maar evident was dat juist gezien het belang hiervan grote zorgvuldigheid was geboden ten aanzien van de overeengekomen procedures, die kennelijk niet voldoende door de overheid en de sector werd betracht.

In de laatste jaren verschoof de feitelijk rond Schiphol gehanteerde participatieve multi-actorbenadering naar de achtergrond. Toepassing van deze benadering leidde immers niet tot het doorbreken van de al zo lang bestaande impasse. Naast de door de minister geïnitieerde fasering van de menings- en besluitvorming werden tevens procedures vastgesteld om de kwaliteit van het proces van meningsvorming te verhogen. Dit waren deels wettelijk verplichte, deels additionele procedures. De ingebruikneming van de vijfde baan was wettelijk onderhevig aan de PKB-procedure, dus inclusief milieueffectrapportage (MER). Deze nieuwe PKB, die met het aannemen in juni 2002 van de 'Schipholwet' door de Eerste Kamer werd afgerond, stelde de eis dat het nieuwe stelsel van milieu- en veiligheidsnormen 'gelijkwaardig' diende te zijn aan het voorheen gehanteerde stelsel, maar beter meetbaar en handhaafbaar.

Het kabinet heeft inmiddels besloten voor de kwestie van de luchtvaartinfrastructuur op de lange termijn, als eerste stap eveneens een PKB te nemen. Ook hier worden derhalve een MER en een economische effectrapportage (EER) uitgevoerd en zijn commissies ingesteld om erop toe te zien dat zo goed mogelijk van wetenschappelijke kennis gebruik wordt gemaakt. Beide rapportages dienen als basis voor een maatschappelijke kosten-batenanalyse (MKBA) teneinde uiteindelijk een optimale afweging tussen de verschillende bestudeerde alternatieven te kunnen maken. Er is een derde commissie (commissie-Van Gelder) ingesteld die de kwaliteit van het proces van besluitvorming bewaakt, onder andere door erop toe te zien dat met de belangen van alle stakeholders rekening wordt gehouden bij de berekening van de maatschappelijke kosten en baten op basis van kengetallen (KКBA) bij de verschillende alternatieven ten aanzien van locatiekeuze en baanconfiguraties. 
Met deze fasering en kwaliteitsbewaking wordt via de wettelijk verplichte en aanvullende zorgvuldigheidsprocedures beoogd dat de besluitvorming op rechtmatige en aanvaardbare wijze geschiedt en derhalve zoveel mogelijk recht wordt gedaan aan de in het geding zijnde belangen. Echter, zo worden de betrokkenen wel op enige afstand geplaatst. Het recht doen aan hun belangen geschiedt nu immers door deze niet via representatie maar inhoudelijk te betrekken in het MKBA-onderzoek, welk proces wordt bewaakt door de commissie-Van Gelder. De uiteenlopende, door de diverse groeperingen ingebrachte argumenten, onderzoeksresultaten, verwachtingen en wegingen, die eerder resulteerden in wellesnietes-discussies en patstellingen, worden zo object van onafhankelijk onderzoek. Via veronafhankelijking van de kennisbasis van de argumentatie tracht men tot aanvaardbare probleemdefiniëring en oplossingen te komen. Deze 'technocratisering' trekt een zware wissel op het onderbouwende onderzoek. Zij plaatst de wetenschap in de rol van een conflictbeslechter, zij het dat alle rapportages (KKBA, EER, MER, MKBA) de status hebben van beleidsadviezen. Vanwege de geldende onzekerheden zijn hierin namelijk verschillende alternatieve berekeningen bij wijze van onzekerheidsvarianten gegeven, zodat de rapportages geenszins een duidelijke beleidskeuze indiceren. Een voordeel van deze werkwijze is dat de feitelijke grondslag van de vele claims over voor- en nadelen van uitbreiding op zo objectief mogelijke wijze kan worden bepaald. Een ander voordeel is dat nu inhoudelijke belangen expliciet aan bod komen die zich eerder niet als zodanig manifesteerden. Tegelijk is de kennisonzekerheid ten aanzien van vele vraagstukken zeer groot; vandaar de genoemde nadruk op onzekerheidsvarianten. Dit betreft niet zozeer zuiver milieukundige aspecten, maar vooral de kosten en baten van modaliteiten binnen het raamwerk van de vastgestelde milieunormen. Dit geldt bijvoorbeeld voor de gevolgen van het beperken van het vliegverkeer voor de economie (bedrijvigheid, ruimtelijke spreiding, indirecte effecten), de ongerestricteerde toekomstige vraag (prijsbeleid, economische ontwikkeling, allianties, transitverkeer via hubs versus directe verbindingen), aanbodrestricties bij verschillende baanconfiguraties, benodigde landzijdige infrastructuur, en gevolgen van modaliteiten van privatisering (liberalisering van de luchtvaart met mogelijkheid van slotveilingen, afroming monopoliewinsten single till of dual till). Bij deze onzekerheden speelt ook mee dat men voor bepaalde onderwerpen toch afhankelijk is van de expertise waar met name de sector zelf over beschikt. Dit geldt bijvoorbeeld voor de mogelijkheden van aanvliegroutes en de hiermee verbonden geluidsbelasting, vervangbaarheid van de huidige vloot door geluidsarmere vliegtuigen, mogelijkheden om tot een goede veiling van slots te komen. De verschillende commissies dienen dan ook bij wijze van second opinion andere deskundigen te horen.

Bij alle objectivering van de kosten en baten is de uiteindelijke afweging van de alternatieven op grond van hun kosten en baten, imponderabilia en onzekerheden vanzelfsprekend geen waardevrije aangelegenheid. Kosten-batenanalyses kunnen de verwevenheid tussen al de in het geding zijnde aspecten en tussen effecten op verschillende schaalniveaus zichtbaar maken, maar de weging binnen de alternatieven zowel als de uiteindelijke afweging tussen die alternatieven is 
geen wetenschappelijke maar een politieke verantwoordelijkheid. Zo is het binnen de nieuwe geluidsgrenzen opereren allerminst een louter technisch meetprobleem. Het impliceert bijvoorbeeld een normatieve keuze ten aanzien van belastingverschillen's nachts en overdag (er is heel wat discussie of de ochtend om zes uur of om zeven uur begint), en stelt ook een scherpe grens tussen gehinderden en niet-gehinderden. De kwestie van de vaststelling en toedeling van de eigendomsrechten is hiermee, zoals gezegd, nog niet definitief opgelost. Buiten de oude $35 \mathrm{Ke}$ (Kosteneenheden) en de daarmee gelijkwaardige nieuwe Ldennormen (Level, day, evening, night) voor geluidscontouren kan Schiphol de geluidsbelasting als het ware - zij het binnen in algemene termen gestelde beperkingen - zonder meer uitbreiden. De verdelingsvraag die binnen de geluidsnorm resteert, is reeds besproken. Bij de ene baanconfiguratie is er voor sommigen meer geluidsoverlast dan bij een andere baanconfiguratie. Daarbij is die verdeling ook nog eens afhankelijk van aanvlieg- en uitvliegroutes.

Evenals bij Rijnmond doemt ook hier weer het beeld op van een sector waarvan de milieuprestatie lang op zijn beloop werd gelaten. De door de hinder getroffenen moesten zelf of met hun zaakwaarnemers in het geweer komen om het aarzelende bestuur uiteindelijk in beweging te krijgen. Het door de overheid langdurig de hand boven het hoofd houden van de sector heeft geleid tot een aanzienlijk wantrouwen in de overheid, evenals in de vroege fase van de Rijnmond-casus. Daar speelde het nieuw gevormde Openbaar Lichaam Rijnmond als nieuwe, voor de getroffen bewoners zeer responsieve instelling een doorslaggevende bijdrage aan het herstel van vertrouwen. Schiphol ontbeert zo'n relatief onafhankelijke, 'onbesmette' institutie; het herstel van vertrouwen wordt hier vooral gezocht in een zeer zware rol voor aan reguliere besluitvormingsmechanismen verbonden onderzoek en onafhankelijke commissies die op de kwaliteit toezien. Of deze veronafhankelijking, door de betwiste elementen via onafhankelijk onderzoek en advies te beslechten, toereikend is voor de maatschappelijke aanvaardbaarheid van de besluitvorming, moet nog blijken. Dat vereist immers ook een ontvankelijkheid van de overheid en de sector voor de ontvangen adviezen. Speelde het ingestelde meetsysteem en de klachtenlijn in Rijnmond een doorslaggevende rol bij het afnemen van het wantrouwen bij de bevolking, in Schiphol is het nog lang niet zover. De ontwikkeling van het in 2003 in gebruik te nemen nieuwe normenstelsel en de te hanteren geluidsmaat wordt met grote argwaan gevolgd. Uitgangspunt is dat het nieuwe normenstelsel gelijkwaardig dient te zijn aan het oude, maar beter handhaafbaar en transparanter moet zijn en bovendien voldoet aan eisen ingevolge de Europese richtlijn (2000). De discussie over het meetsysteem spitst zich ten eerste toe op de mate waarin de geluidsproductie direct gemeten moet worden dan wel wordt berekend op basis van vluchtgegevens, ten tweede op het gebied dat bemeten dient te worden, ten derde op de vraag of rekening moet worden gehouden met de mate van bewoning, en ten slotte op het aantal meetpunten. De argwaan bij de bevolking is echter groot dat de geluidsoverlast voor de bewoners buiten de sterk in aantal teruggebrachte handhavingspunten juist toeneemt. Ook hier bestaat een klachtenlijn, maar de interpretatie is lastiger dan in Rijnmond. Het verband tussen voorkeuren, afruil- 
waarden en aantallen klachten, en zelfs aantallen klagers, is namelijk moeilijk te bepalen. Objectieve meting blijkt toch het beste, waarbij de technische discussie tussen scheiding van vliegtuiglawaai en overig lawaai ook nog eens speelt.

De commissie-Berkhout, die in 2000 is ingesteld om (de overgang naar) het nieuwe normenstelsel te toetsen aan de beleidsuitgangspunten gelijkwaardigheid, transparantie en handhaafbaarheid, heeft echter eind 2002 haar opdracht teruggegeven. Blijkens het door de commissievoorzitter hierover gepubliceerde relaas voldoet het nieuwe normenstelsel niet aan deze uitgangspunten, vinden haar voorstellen voor verbetering geen gehoor bij de betrokken ministeries en ondervindt zij stelselmatig tegenwerking in de uitoefening van haar toegekende taken (Berkhout 2003). Ook de genoemde veronafhankelijking blijkt derhalve geen voldoende voorwaarde voor een soepel verlopend besluitvormingsproces in complexe en controversiële situaties. Basisvoorwaarde hiervoor is ten minste dat de overheid als regisseur van dat proces zich als betrouwbare partij doet kennen en de regels respecteert die zij zelf aan het 'spel' heeft opgelegd.

\subsection{RICHTLIJNEN UIT BRUSSEL: DE VOGELRICHTLIJN EN DE NITRAATRICHTLIJN}

\section{$4 \cdot 3 \cdot 1 \quad$ INLEIDING}

Waren het bij de twee vorige casussen primair de door hinder getroffenen zelf dan wel hun zaakwaarnemers die de overheid aanzetten tot handelen, deze paragraaf behandelt twee voorbeelden waar de beleidsimpuls vooral uit Brussel komt. Hoewel op beide gebieden ook wel beleid werd gevoerd voordat de EU tot een richtlijn besloot, was het toch de richtlijn die de Nederlandse overheid confronteerde met de plicht tot uitvoering van een veel ingrijpender taakstelling.

\subsubsection{DE VOGELRICHTLIJN}

De grondgedachte dat flora en fauna beide een door de wetgever te beschermen maatschappelijk goed zouden zijn, heeft in Nederland een stevige verankering: al in 1880 kreeg Nederland een Vogelwet. Nederland was dan ook, als een van de initiatiefnemers, een groot voorstander van de Vogelrichtlijn (1979): wat in Nederland al jaren als goed beleid gold, moest Europees beleid worden. Hierdoor zou een einde worden gemaakt aan de jachtpartijen in de Zuid-Europese landen, zo was de gedachte. De aanvaardbaarheid van de gedachten achter de Vogelrichtlijn en ook de latere Habitatrichtlijn (1992) stond in Nederland, in tegenstelling tot bijvoorbeeld in Frankrijk, dan ook niet ter discussie. Zo is het beginsel van biodiversiteit, waarvoor de overheid een eindverantwoordelijkheid heeft, bevestigd in talloze verdragen, waarvan Nederland partij is. Anders dan in Duitsland en Denemarken is hier ook de rechtmatigheid van Europese bemoeienis met dit onderwerp onomstreden. Het gaat immers om grensoverschrijdend verkeer en communautaire samenhang, waarbij de overweging speelt dat wat op nationaal 
niveau niet bedreigd en zeldzaam is dat heel wel het geval kan zijn op Europees niveau. Beide richtlijnen ondersteunen zo ook de door Nederland voorgestane latere denkbeelden omtrent een Europese ecologische hoofdstructuur, waardoor genetische uitwisseling de kans op overleven van soorten en biotopen vergroot.

Omdat iedere EU-regeling voor het milieu formeel moet zijn gebaseerd op wetenschappelijke feiten berust ook deze richtlijn op uitgebreid wetenschappelijk onderzoek. Door onafhankelijke experts van de Eurogroup for the Conservation of Birds en de International Council for Bird Preservation is en wordt uitgebreid onderzoek verricht naar de ecologische stand van zaken ten aanzien van vogelstand en -bewegingen en mogelijke remedies. Op nationaal niveau worden de ontwikkelingen gevolgd door met name sovon Onderzoek Nederland.

De richtlijn kent een hoge mate van afdwingbaarheid. Ter bescherming van bedreigde en zeldzame vogelsoorten wordt aan nationale overheden de verplichting opgelegd om op basis van Europese zuiver ecologische, vogelkundige criteria bepaalde speciale beschermingsgebieden aan te wijzen en deze ecologisch goed te beheren. De in opdracht van en in overleg met de Europese Commissie door wetenschappers vastgestelde List Important Bird Areas heeft hierbij de juridische status van vermoeden van bewijs. Wanneer lidstaten van de lijst willen afwijken, moeten zij aantonen waarom gebieden niet tot de "voor aanwijzing meest geschikte" gebieden behoren, zoals bedoeld in artikel 4 van de richtlijn. De rechtsgevolgen van zo'n 'aanwijzing' zijn dat de overheden een algemene zorgplicht hebben voor ecologisch beheer en dat zij preventieve maatregelen moeten nemen ter voorkoming van verslechtering van leefgebieden en van significante verstoring van soorten waarvoor het gebied is aangewezen. Voorts moeten plannen en projecten voor dit gebied aan een groot aantal vereisten voldoen: er moet vooraf een ecologische evaluatie plaatsvinden en bij mogelijke schade mogen plan of project alleen doorgaan wanneer sprake is van een dwingend openbaar belang en er geen alternatieven zijn en dient bovendien tijdige, volledige ecologische compensatie te worden gegeven. De EU stelt derhalve het afwegingskader: voor bepaalde gebieden wordt prioriteit toegekend aan het ecologische belang waarvan afwijking alleen is toegestaan binnen door de EU gestelde voorwaarden. Aldus is een flinke beperking gesteld aan de autonomie van vooral lagere overheden bij het inrichten van gebieden.

Zo aanvaard de richtlijn in Nederland was bij de beleidsvorming, zo controversieel bleek ze in de jaren negentig bij de implementatie. Anders dan aanvankelijk verwacht, bleek ze namelijk wel degelijk aanzienlijke consequenties te hebben, op alle bestuurlijke niveaus. Het Europese Hof van Justitie nam directe werking van de richtlijn aan en dit werd door de nationale rechter overgenomen. Het Hof legde Nederland de verplichting op tot verdubbeling van het beschermde areaal (tot in totaal 800.000 hectare). Ook vond de Nederlandse soft law-benadering via PKB's en convenanten geen genade in Luxemburg: beleidsmatige inspanning was onvoldoende, Nederland moest zich gewoon aan de regels houden, zo vonniste het Hof. Al met al vormde de implementatie onderwerp van vier rechts- 
gedingen bij het Europese Hof tegen Nederland, en werden enkele inbreukprocedures gestart. Onder druk hiervan en vanwege de dreiging van zware boetes moest Nederland het nationale beleid bijstellen, bijvoorbeeld door de recente aanpassing van de nieuwe Natuurbeschermingswet en hieruit voortvloeiende aanwijzingsbesluiten van beschermde gebieden (Backus 1995; 2000). Door de val van het tweede kabinet-Kok is de behandeling echter stilgelegd, en is door het kabinet-Balkenende een nieuwe aanpassing aangekondigd.

De versnelde aanwijzing waartoe Nederland werd verplicht, leidde tot een groot aantal nationale activiteiten: de instelling van een adviescommissie voor selectiecriteria; overleg; voorlichting; en inspraak ten aanzien van de conceptbesluiten. De poging om alsnog, terwille van de haalbaarheid, door middel van een breed participatiebeleid voldoende draagvlak te creëren, was echter weinig succesvol. De uitvoering ging gepaard met aanzienlijk verzet, met name bij lagere overheden, boeren-, visserij- en recreatieorganisaties, VNO/NCW en Kamers van Koophandel, die alle de richtlijn ervoeren als een forse inbreuk op de inrichtingsvrijheid en de Nederlandse planningspraktijk. Gesproken werd van 'ecologisch dictaat' en een 'historische vergissing' (Leget 200o). Naast het doorkruisen van zorgvuldig opgebouwd, democratisch nationaal beleid betrof de kritiek de grote haast, de onduidelijke selectiecriteria, de in hun rechtsgevolgen meerduidige en onwerkbare normen en onvoldoende geactualiseerde tellingen. Nadere uitwerking van de nationale criteria en actualisering van de telgegevens resulteerden echter in slechts beperkte bijstellingen van het aantal beschermingsgebieden.

De hoge mate van initiële aanvaardbaarheid sloeg bij de implementatie derhalve om in haar tegendeel. Aanvaardbaarheid van een principe bleek toch iets anders te zijn dan aanvaardbaarheid van de eruit voortvloeiende gedragsconsequenties; de stakes verschilden natuurlijk ook navenant. Een nationaal debat waarin niet alleen de natuurbescherming maar eveneens de door de implementatie geraakte belangen zich deden gelden, vond derhalve pas plaats toen het al te laat was, althans vanuit het gezichtspunt van de laatsten. Toch was ook de totstandkoming van de richtlijn gepaard gegaan met een formeel open procedure, waarbij maatschappelijke organisaties inspraakmogelijkheden hadden via het Economisch en Sociaal Comité (de Europese SER) en het Europees Parlement. Hiervan hadden belangengroeperingen die door de toepassing geraakt bleken, echter geen gebruikgemaakt. Op Europees niveau werd aan het debat over de richtlijn alleen deelgenomen door een beperkt aantal (inter)nationale milieuorganisaties. Dit tekende de grove onderschatting van de consequenties, ook van de mate waarin het zou gaan om bindend recht. Aanvankelijk werd immers verondersteld, ook door de regering, dat de reguliere 'zachte' Nederlandse benadering, met een meer open afweging en interactieve bestuursstijl, niet in het geding was. In feite voelden alle nationale partijen zich overvallen door de Europese dynamiek. Veel sterker dan gebruikelijk was op het gebied van natuurbescherming werd nu geëist dat regels ook werden uitgevoerd. Dit wijst op het belang van de scharnierfunctie van de nationale overheid in het activeren van nationale betrokkenheid bij in- en uitvoering van de Europese regelgeving. 
Bij alle problemen in de sfeer van de haalbaarheid, lijkt de richtlijn - afgemeten aan de opgelegde verplichtingen - toch doeltreffend te zijn. Het aantal beschermingszones is aanzienlijk uitgebreid en ook de oorspronkelijke categorie gebieden heeft nu een juridisch beschermde status, terwijl deze binnen het Nederlandse recht eerder alleen een beleidsmatige bescherming genoot. Tegen de besluiten is weliswaar een groot aantal bezwaar- en beroepschriften ingediend, maar de verwachting is dat deze vanwege het dwingend rechtskarakter van de richtlijn niet zullen worden gehonoreerd. Ook in andere Europese landen sorteert de richtlijn een behoorlijk effect: de jacht op trekvogels is sterk verminderd. Tegelijk moet worden onderkend dat de doelmatigheid ermee gediend zou zijn geweest wanneer de consequenties eerder onder ogen waren gezien en onderwerp van nationaal debat waren geweest. Hoewel ten dele onvermijdelijk is dat bij beleid gericht op vraagstukken die geen hinder aan mensen veroorzaken, de gedragsconsequenties pas bij implementatie duidelijk worden, was eerdere signalering dan pas in de jaren negentig toch goed denkbaar geweest. De richtlijn is immers al sinds 1981 van kracht. Symptomatisch is dat in bijvoorbeeld het IPO/LNV-convenant van 1997 over de overdracht van bevoegdheden aan provincies voor het realiseren van de ecologische hoofdstructuur geen enkele aandacht aan de Vogel- en Habitatrichtlijn is gegeven. Zelfs in de LNV-nota uit 2000 Natuur voor mensen, mensen voor natuur ontbreekt deze aandacht vrijwel. In de Nota van Antwoord Vogelrichtlijn LNV 2000 wordt dan ook toegegeven dat de communicatie over deze richtlijnen binnen Nederland de afgelopen twintig jaar inderdaad erg sober is geweest (Van der Zouwen en Van Tatenhove 2002: 13 e.v.).

In elk geval attendeert deze casus op een kenmerk waar Nederland steeds vaker mee wordt geconfronteerd, te weten internationaal dwingend recht dat op rechtmatige wijze tot stand is gekomen, zowel waar het gaat om de wetenschappelijke fundering als het bieden van inspraakmogelijkheden, maar dat nationaal moet worden uitgevoerd. Op het terrein van deze casus blijkt dit zich slecht te verhouden tot 'onze manier' van schikken en plooien, waarbij er een voortdurende iteratie tussen doelen en middelen plaatsvindt. Weliswaar komt de zo nagestreefde instemming van alle betrokkenen de aanvaardbaarheid van de uiteindelijke gekozen beleidslijn ten goede, maar leidt dit niet altijd tot uitkomsten die in de buurt komen van de oorspronkelijk aanvaarde probleemdefinitie.

\subsubsection{DE NITRAATRICHTLIJN}

De Nitraatrichtlijn (1991) confronteerde Nederland eveneens met een uitvoeringsplicht. Nederland koos voor een weinig voortvarende aanpak, hetgeen uiteindelijk resulteerde in een sterk nationaal gekleurd stelsel van doel- en vooral ook middelvoorschriften aan boeren.

De geschiedenis van pogingen het mestprobleem onder controle te krijgen, dateert al vanaf de jaren tachtig. Het sterke naoorlogse accent op verhoging van de landbouwproductie had het bemestingsniveau in Nederland opgevoerd tot het hoogste ter wereld. In de jaren zeventig werd duidelijk dat dit - naast een beïn- 
vloeding van de luchtkwaliteit door vervluchtiging van ammoniak - een negatief effect had op onder andere de grondwaterkwaliteit. Het niet door het gewas gebruikte stikstof spoelde als nitraat uit naar grond- en oppervlaktewater. De eerste wetgeving in 1987 plafonneerde de jaarlijkse hoeveelheid mestgebruik per bedrijf en verbood het uitrijden van mest buiten het groeiseizoen. (In voor- en najaar overtreft de neerslag de verdamping en groeien de planten nauwelijks, zodat de toegevoegde stikstof in veel sterkere mate naar oppervlakte- en grondwater wordt afgevoerd.) In 1991 volgde de Europese Nitraatrichtlijn, die in eerste instantie in Nederland nauwelijks aandacht kreeg (Henkens en Van Keulen 2001: 117-134). Pas zeven jaar later, in 1998, werd de op de richtlijn gebaseerde MINASwetgeving formeel ingevoerd.

De Nitraatrichtlijn heeft als oogmerk de watervervuiling door nitraat door de landbouw te reduceren en verdere vervuiling te voorkomen. De richtlijn legt de lidstaten de verplichting op vulnerable zones aan te wijzen. Voor deze gebieden dienen er actie- en controleprogramma's te komen die bewerkstelligen dat de hoeveelheid nitraat in het grondwater niet meer is dan 50 milligram per liter. Hiertoe dient de stikstofbemesting per boerderij niet meer te zijn dan overeenkomt met 170 kilo per hectare. Voorts dienen er codes of good agricultural practices te worden geformuleerd.

Nederland, dat in zijn geheel geldt als een vulnerable zone, heeft hiertoe de verplichting voor alle individuele boeren ingevoerd om vanaf 1998 het zogenoemde Mineralenaangiftesysteem (MINAS) bij te houden. In dit mestboekhoudsysteem moeten boeren precies administreren wat er aan stikstof (en fosfaat) het bedrijf binnenkomt en weer verlaat, zodat het farm surplus kan worden vastgesteld. Voor verschillende bodems en bedrijfssystemen zijn kritieke waarden voor het toegestane surplus vastgesteld. Wanneer boeren deze van jaar tot jaar aangescherpte normen overschrijden, dient een heffing te worden betaald. Parallel hieraan zijn tezelfdertijd ook nieuwe voorschriften in werking getreden waarbij het uitrijden van mest nu ook in het groeiseizoen wordt beperkt, en is er een verplichting gekomen tot het injecteren van vloeibare mest in het bodemoppervlak teneinde vervluchtiging van ammoniak tegen te gaan. Hiernaast zijn er nog flankerende maatregelen om het probleem van het mestoverschot (de hoeveelheid mest die meer wordt geproduceerd dan nodig is voor een ecologisch verantwoord bemestingsregime) te verlichten door andere maatregelen dan die welke zijn gericht op de bedrijfsvoering. De grote regionale onevenwichtigheid tussen mestproductie en -gebruik heeft men getracht tegen te gaan door een opkoopsysteem van mestrechten, na het eerdere echec met fabrieksmatige verwerking van varkens- en kippenmest. Ook is het beleid 'woningen voor schuren' totstandgebracht, waarbij de overheid boeren toestaat hun bedrijf te verkopen als bouwkavel (tegen marktprijs voor bouwgrond), en is de overheid overgegaan tot het zeer kostbare uitkopen van boeren. Thans geldt een systeem van mestafzetovereenkomsten, waarbij boeren verplicht zijn voor de mestproductie die een hoeveelheid stikstof levert hoger dan 170 kilo per hectare afzetcontracten te sluiten met boeren die een tekort hebben. Dit systeem verhoudt zich echter niet goed tot de 
systematiek van het MINAS, en leidt in de praktijk tot 'loze' contracten zonder consequenties (Ministerie van LNV 2002).

In december 2002 zouden de door de EU voorgeschreven maximale bemestingsniveaus moeten zijn gerealiseerd en hiertoe zou de EU het Nederlandse mestbeleid, waarvan MINAS een onderdeel is, toetsen. De Advocaat-Generaal van het Hof van Justitie heeft het Nederlandse beleid inmiddels veroordeeld; naar verwachting zal het tot een formele veroordeling komen en krijgt Nederland sancties opgelegd wegens het niet nakomen van de uitvoeringsverplichting. In de afgelopen jaren tekende zich dit al af. Zo verscheen in 2001 een zeer kritisch rapport van de Algemene Rekenkamer over de implementatie: het MINAS werkt niet, het is te ingewikkeld, het doel ervan is de boeren niet duidelijk en de handhaving vanuit het ministerie schiet schromelijk tekort (Algemene Rekenkamer 2001). De EU ziet het systeem echter niet als een alternatief voor de in de richtlijn neergelegde voorschriften, maar als een toevoeging. Het gaat de Unie derhalve niet zozeer om de handhavingsprestatie ten aanzien van de MINAS-normen (het farm surplus), maar om het nitraatgehalte in het grondwater en het aangrijpingspunt hiervoor (als proxy) van de 170 kilo per hectare. In haar in 2002 verschenen rapport signaleert de Commissie Evaluatie Meststoffenwet (RIVM 2002a) dat het nitraatgehalte in het grondwater in de zandgebieden overal nog veel te hoog is (gemiddeld 120 milligram per liter in plaats van de door de EU geëiste 50 milligram per liter). Ook de ammoniakemissies vanuit mest zijn nog veel te hoog. Hoewel de situatie rond de mestboekhouding is verbeterd, voldoet nog maar een klein deel van de boeren aan de MINAS-normen. Er is hoogstens ruimte voor de verwachting dat de situatie verder zal verbeteren. De evaluatiecommissie acht het voorts niet rechtvaardig dat de MINAS-normen per 2003 voor droogtegevoelige gronden verder worden aangescherpt, zoals de regering wil. De redenen hiervoor zijn drieërlei. Abrupte aanscherping zou tot veel faillissementen leiden. Bovendien worden in de praktijk initiatieven genomen zoals anders voeren en periodieke toediening van mest; die initiatieven hebben weliswaar geen relatie met het MINAS, maar wel degelijk met de achterliggende doelen. Ook de wetenschappelijke onderbouwing voor aanscherping wordt onvolledig geacht, omdat voor drinkwaterwinning niet het bovenste grondwater maar de diepere lagen van belang zijn. Op weg naar die diepere lagen kan het nitraat nog worden afgebroken. De voorschriften van de EU zijn in dit opzicht onduidelijk; voor het vaststellen van de norm van 50 milligram nitraat per liter wordt gesproken van 'metingen in de bovenste lagen van ondiep grondwater'. Nederland verricht metingen in de bovenste meter, maar bijvoorbeeld Denemarken interpreteert 'ondiep' tot een diepte van vijf meter.

Geldt dit argument voor de specifiek aan het MINAS gekoppelde normering, in 1999 had het RIVM al een rapport gepubliceerd als basis voor een derogatieverzoek van de Nederlandse regering. Onderzoek van Willems et al. (2000) toont namelijk aan dat de door de EU vastgestelde grens van maximaal 170 kilo stikstof per hectare voor grasland kan worden verschoven naar 290 à 360 kilo nitraat per ha zonder dat de kritieke nitraatgrens van 50 milligram per liter wordt overschre- 
den. Deze kritiek van het RIVM en ook het eerdergenoemde commentaar van de Commissie Evaluatie Meststoffenwet betreffen derhalve de aard van de normering zelf van zowel richtlijn als MINAs. De wetenschappelijke onderbouwing ervan is ook een van de factoren achter controverses die alle vier aspecten van goed beleid parten spelen.

De basis van de Nitraatrichtlijn wordt gevormd door de norm van maximaal 50 milligram nitraat per liter voor grondwater. Deze norm is opgesteld door de Wereld Gezondheidsorganisatie en is gebaseerd op de zogenoemde ADI (acceptable daily intake) van 3,7 milligram nitraat per kilo lichaamsgewicht en is afgeleid uit experimenten met proefdieren. De norm van 3,7 milligram is wetenschappelijk onomstreden en is gebaseerd op eenduidig klinisch onderzoek. Periodiek opduikende publicaties van tegenstanders van de Nitraatrichtlijn die suggereren dat nitraat niet schadelijk zou zijn en zelfs goed is voor de gezondheid (bijv. Addiscott en Benjamin 200o) zijn niet wetenschappelijk onderbouwd. De vertaalstap van de genoemde norm naar 50 milligram per liter nitraat in drinkwater houdt echter wel een aantal arbitraire aannames in op het punt van de verwachte consumptie van drinkwater en groenten door een persoon van 70 kilo. De 50 milligram per liter is duidelijk minder hard dan de norm van 3,7 milligram nitraat per kilo lichaamsgewicht. Bovendien is sprake van een wel zeer grote veiligheidsmarge door de directe vertaling van de drinkwaternorm naar grondwater. Deze veiligheidsmarge wordt in de praktijk nog vergroot doordat alleen in zandgebieden drinkwater wordt opgepompt, en wel - zoals gezegd - vanaf grote diepte. De relatie tussen emissies van ammoniak en zure regen is theoretisch echter zeer complex, en hetzelfde geldt voor de gang van nitraat naar het grondwater en daarbinnen naar grotere diepte; hierbij treden vele omzettingen op waarbij nitraat verdwijnt. Deze staan bovendien niet los van de grondsoort. Bovendien is het gehalte aan ammoniak en nitraat in het veld en het grondwater zelf moeilijk snel en goedkoop te meten. Daarom worden in de praktijk zogenoemde proxy-waarden gedefinieerd; deze zijn gemakkelijker te meten en te controleren. Dit gebruik van proxies geldt al voor de richtlijn zelf (maximaal 170 kilo stikstof per hectare), maar de farm surplus-normen die ter uitwerking hiervan in het MINAS alsmede in de andere voorschriften (uitrijverboden en onderploegen) worden gehanteerd, zijn nog verder verwijderd van de oorspronkelijke grondwaternorm.

Ook als men in principe instemt met de gestelde - op zich al erg veilig gedefinieerde - drinkwaternorm, behoeft dit nog niet uit te sluiten dat er ernstige vraagtekens kunnen worden geplaatst bij de uiteindelijk opgelegde gedragsnormen als proxies. Dit geldt voor de wetenschap, van waaruit herhaaldelijk is gewezen op de grote onzekerheden in de keten van adi naar gedragsvoorschriften voor de boer, het geldt ook voor de boeren zelf. Hoewel zij het doel van 'schoon' water van meet af onderschreven, hebben zij vraagtekens gezet bij ten eerste de verwaarlozing door de generieke normering van de specifieke bodemkenmerken, ten tweede de eis van drinkwaterkwaliteit van hun grondwater op een diepte van slechts een meter beneden het maaiveld, en ten derde bij relatie tussen bemes- 
tingsniveau en nitraatuitspoeling. Ook hebben zij nooit begrepen waarom het zeer dure injecteren van mest wettelijk voorgeschreven is. In bepaalde omstandigheden kan dit de uitspoeling naar het grondwater juist bevorderen. In feite is dit laatste het gevolg van twee gescheiden regelcircuits: het ene is gericht op vermindering van de uitspoeling van nitraat, het andere op vermindering van de emissie van ammoniak. Dit is een weinig effectieve beleidscumulatie, die bovendien bepaald niet bevorderlijk is voor het begrip en hiermee de aanvaardbaarheid.

Wetenschappelijke vraagtekens, ervaringskennis en beleidsinconsistenties hebben bijgedragen aan grote problemen rond de principiële aanvaardbaarheid en praktische haalbaarheid. De aard van het zeer bewerkelijke en moeilijk handhaafbare karakter van het MINAS-systeem (er zijn ca. 100.00o boeren), brachten de Rekenkamer tot bovengenoemde kanttekeningen over de effectiviteit. De rechtmatigheid van de Nitraatrichtlijn wordt niet in twijfel getrokken, hoewel het genoemde derogatieverzoek aangeeft dat deze te weinig differentieert naar bodemsoort. Het verzet heeft met name betrekking op de wijze waarop Nederland vorm en inhoud heeft gegeven aan zijn implementatieverplichting. Anders dan bij de Vogelrichtlijn, waar Nederland dacht het beleid al op orde te hebben, is de uitvoering van de Nitraatrichtlijn voortvarend ter hand genomen. Dit heeft top-down plaatsgevonden en heeft geresulteerd in een omstreden en voor alle actoren zeer bewerkelijk systeem. Aan tijdige communicatie met en participatie door de doelgroep heeft het ontbroken, waardoor deze is geconfronteerd met ingrijpende eisen die deels als willekeurig overkwamen. Het zoeken naar een systeem van uitvoering dat beter voldeed aan de doelstelling en eenvoudiger handhaafbaar was, had het draagvlak kunnen vergroten, zonder dat de richtlijn geweld zou zijn aangedaan. In dat geval had via tijdige participatie een systeem gevonden kunnen worden dat de aanvaardbaarheid, de haalbaarheid, de effectiviteit en de efficiëntie ten goede had kunnen komen.

De richtlijn geldt vanzelfsprekend ook voor andere landen. Met name Denemarken kent eveneens een groot mestprobleem, en geldt evenals Nederland geheel als vulnerable zone. Het land lijkt er beter in geslaagd te zijn de richtlijn te implementeren. Het gehanteerde systeem is transparanter en laat de boer meer vrijheidsgraden om de per bedrijf toegestane hoeveelheid stikstof (farm quota) te bereiken. De meeste boeren bleken in 2002 minder stikstof per hectare te gebruiken dan is toegestaan. Zoals al eerder vermeld, interpreteert Denemarken de vereiste diepte voor het realiseren van de grondwaternorm minder strikt dan Nederland. Bovendien is de reductieopgave voor Denemarken veel minder ingrijpend geweest: was in 1997 de totale stikstofbemesting in Nederland 490 kilo per hectare, in Denemarken was dit slechts 205 kilo per hectare. De richtlijn houdt echter geen rekening met deze verschillen tussen de lidstaten, bijvoorbeeld door een differentiatie in tijdpad.

Dat de door de Unie opgelegde en door Nederland nader uitgewerkte normen het boeren niet onmogelijk maakt, blijkt ook uit ervaringen in Nederland zelf. Zo is 
er in Friesland een milieucoöperatie gevormd die werkt aan het realiseren van milieueisen rond stikstof. Het uitgangspunt hierbij is dat men best de milieudoelen wil realiseren, maar daartoe zelf de middelen wenst te kiezen. Om dit initiatief te ondersteunen, heeft de minister van LNV de wettelijke regels over onder andere mestinjectie tijdelijk opgeschort: een voorbeeld van de convenantenbenadering die in de landbouw uitzonderlijk is. Het experiment maakt gebruik van ondersteunend onderzoek, waarvan de doelstelling door de coöperatie zelf wordt gedefinieerd. De resultaten geven aan dat de wettelijke normen - zelfs ook sommige van de aanvullende MINAS-normen - zeer wel zijn te halen met een aangepaste bedrijfsvoering; de grondwaternorm zelfs zonder al te veel moeite. Sociale controle vervult hierbij een belangrijke rol en stimuleert de onderlinge prestatiegerichtheid van de boeren. Zelfs in die mate dat het bestuur van de coöperatie (dat geheel uit boeren bestaat) nu voorstelt een aantal normen aan te scherpen en deelnemende boeren scherper af te rekenen op hun prestaties. Inmiddels zijn er in Nederland meer dan 100 van dergelijke milieucoöperaties.

De mogelijkheden om te leren van ervaringen in het buitenland zijn onbenut gebleven (zie het voorbeeld van Denemarken). Ook heeft het gehanteerde sturingsmodel de innovatie door de sector zelf eerder tegengewerkt dan gefaciliteerd, door het gedrag van boeren vergaand te reguleren. Het beleid heeft zich bij de normering en de voorgeschreven middelen laten leiden door de toen (beperkt) beschikbare kennis; maar het beleidsbestel heeft zich vervolgens afgesloten van nieuwe relevante wetenschappelijke inzichten. Evenmin zijn er beleidsconsequenties verbonden aan de onderzoeksresultaten die uit het Friese voorbeeld naar voren zijn gekomen. Deze hebben immers laten zien dat het uitgangspunt van de nitraatnorm voor grondwater, waar het de richtlijn primair om te doen is, wel degelijk haalbaar is wanneer boeren op hun creativiteit worden aangesproken en de experimenten in goede samenspraak met onderzoekers wetenschappelijk worden begeleid. Multi-actorbenaderingen, zoals bij de milieucoöperaties, hebben de interactieve leerprocessen gericht op het bereiken van de doelen van de Nitraatrichtlijn bevorderd.

De conclusie moet luiden dat met name de aanvaardbaarheid in de beleidsvorming onvoldoende aandacht heeft gekregen. Hiermee is niet gezegd dat het beleid geheel ineffectief is geweest: het mestoverschot is door een scala van - soms zeer kostbare - maatregelen verkleind. Maar door de aard van de Nederlandse regelgeving, met een vergaand voorgeschreven bedrijfsvoering, is het oorspronkelijke doel van de waterkwaliteit buiten beeld geraakt. De regelgeving richt zich te weinig op de relatie tussen bemestingsregime (wat meer inhoudt dan de totale toegevoegde hoeveelheid mest) en de waterkwaliteit. Ook de onderzoekswereld is er slecht in geslaagd om deze relatie inzichtelijk te maken. Omdat boeren hebben laten zien dat het bemestingsregime wel degelijk van cruciaal belang is voor de grondwaterkwaliteit, hetgeen inmiddels ook door onderzoek is bevestigd, komt het beleid op hen over als onrechtvaardig, ook al is het in formele zin rechtmatig. Het verzet van de boeren betrof niet de aanvaardbaarheid en recht- 
matigheid van de EU-richtlijn als zodanig, wel de Nederlandse implementatiestructuur. Juist omdat de EU-doelen op zichzelf aanvaardbaar werden gevonden, had het in de rede gelegen op deze basis in samenspraak met de doelgroep en de onderzoekswereld een beleid te ontwerpen waarvan meer overtuigingskracht was uitgegaan.

\subsection{ONZEKER EN ONZICHTBAAR: KLIMAATVERANDERING EN CHLOORHOUDENDE VERBINDINGEN}

\subsubsection{INLEIDING}

In de beide laatste casussen staat de beleidsvorming in een situatie van grote onzekerheid over de milieuaspecten centraal. Bij Rijnmond en Schiphol ging het om milieuproblemen die zintuiglijk goed waarneembaar zijn, en waarvoor meetsystemen zijn te ontwikkelen die - hoe ingewikkeld ook - de omvang van de problemen kunnen vaststellen. Niet dat kennisonzekerheid deze casussen geen parten speelt; zeker bij Schiphol is deze groot, maar zij betreft vooral de sociaaleconomische kosten en baten van groeimodaliteiten. De milieuproblemen bij de twee Europese richtlijnen zijn al minder zintuiglijk waarneembaar, maar rond de in het geding zijnde doelen - de handhaving van vogelsoorten en van een goede grondwaterkwaliteit en de daarvoor primair benodigde gedragsaanpassing bestaan weinig wetenschappelijke controverses. Dit ligt geheel anders bij de hier te behandelen casussen. Het gaat bovendien om milieuproblemen die zich pas op de lange termijn manifesteren, en waar de baten van het te voeren beleid weinig zichtbaar zijn. Succesvol beleid betekent hier immers het zich niet voordoen van problemen. Zeker in het geval van het klimaat vergt het voorkómen van het veronderstelde broeikaseffect vermoedelijk grote gedragsveranderingen van zeer velen. Het niet direct waarneembaar zijn van de problemen ondergraaft bovendien de prikkel tot het treffen van beleidsmaatregelen. En omdat het beleid de problemen niet te lijf kan gaan op een wijze die voor alle burgers zichtbaar en inzichtelijk is, is het moeilijk een draagvlak voor voortgezet beleid in stand te houden. Dat maakt de beleidsontwikkeling buitengewoon complex, en legt een grote verantwoordelijkheid op de wetenschap als belangrijkste bron van overtuiging van de noodzaak tot beleidshandelen.

\subsubsection{KLIMAATVERANDERING}

De mogelijke verandering van het klimaat is te zien als de kern van de internationale milieuvraagstukken waarmee de wereld wordt geconfronteerd. Een klimaatverandering heeft immers niet alleen invloed op de directe levensomstandigheden van de mens, maar beïnvloedt ook de biodiversiteit, de waterbeschikbaarheid en de voedselvoorziening. Bovendien zijn de snelheid waarmee zij zich voltrekt en de turbulentie waarmee dit gepaard gaat cruciale factoren voor de aanpassingsmogelijkheden van mens, flora en fauna. 
Het vraagstuk staat sinds de World Climate Conference in Genève in 1979 stevig op de internationale wetenschappelijke agenda, hoewel de mogelijkheid van klimaatverandering als gevolg van menselijk handelen al in 1895 door de Zweedse chemicus Arrhenius theoretisch werd geopperd. Naar aanleiding van deze conferentie werd het World Climate Research Programme vastgesteld. Negen jaar later kwam het onderwerp ook op de politieke agenda via de Toronto Conferentie.

Door het United Nations Environment Programme samen met de World Metereological Organization werd toen het Intergovernmental Panel on Climate Change (IPCC) opgericht, als opvolger van de sinds 1985 bestaande Advisory Group on Greenhouse Gases. Het IPCC, waarin een honderdtal klimaatdeskundigen zitting heeft, doet zelf geen onderzoek, maar evalueert de wetenschappelijke, technische en sociaal-economische informatie die relevant is voor het begrijpen van het risico op antropogene klimaatverandering. Men baseert zich hierbij op gepubliceerde en peer reviewed wetenschappelijke literatuur. Vanaf 1990 rapporteert het ipcc zijn beoordelingen over de kans op klimaatverandering, het tempo en de regionale gevolgen ervan, en formuleert het oplossingsrichtingen voor de problemen. Deze beoordelingen besteden grote zorg aan het kwalificeren van de verwachtingen in termen van mate van zekerheid die er wetenschappelijk over bestaat. Dit kwalificatiesysteem is gaandeweg steeds meer gepreciseerd; de waarschijnlijkheidsbeoordelingen kennen inmiddels zeven categorieën die uiteenlopen van virtually certain tot aan exceptionally unlikely. Op grond van de verrichte onderzoekingen in de afgelopen jaren is in vergelijking met de eerdere rapportages de stelligheid van de uitspraken over de waarschijnlijkheid van het antropogene broeikaseffect toegenomen. In het meest recente rapport wordt gesproken van een likely invloed van menselijke activiteit op de klimaatverandering van de afgelopen 50 jaar, terwijl de eveneens geconstateerde stijging van het zeespiegelniveau in de afgelopen eeuw very likely het gevolg is van de opwarming. Bedroeg de opwarming sinds de late jaren vijftig van de vorige eeuw o,1 graad Celsius per decennium, de temperatuurstijging die voor de 21ste eeuw wordt voorzien, bedraagt tussen 1,4 en 5,8 graden Celsius (afhankelijk van het ontwikkelingsscenario). Deze versnelde verdere opwarming is bovendien vrijwel onomkeerbaar door de zeer lange levensduur van broeikasgassen. De scenario's die zijn bestudeerd op hun gevolgen voor het broeikaseffect lopen uiteen naar een groot aantal variabelen, zoals de snelheid van de groei van het BNP, de fossiele energie-intensiteit ervan, de technologische ontwikkeling, de economische structuur, de bevolkingsontwikkeling en de regionale convergentie. Geen van de soms ingrijpende scenario's is in staat verdere opwarming te voorkomen (IPCC 2001). Daartoe zou volgens de door het IPCC gehanteerde modellen een reductie van de $\mathrm{CO}_{2}$-uitstoot van 60 à 90 procent noodzakelijk zijn. Het NMP IV noemt in dit verband een reductiepercentage van 40 à 60 procent in 2030 ten opzichte van 1990, terwijl de Uitvoeringsnota Klimaatbeleid I spreekt van 50 à 75 procent reductie als uiteindelijk streefdoel (VROM 1999: 89). Omdat de optredende opwarming van de aarde niet meer ongedaan kan worden gemaakt, vergt het streven naar stabilisatie volgens het IPCC hoe dan ook dat in de loop van deze eeuw de antropogene emissie van $\mathrm{CO}_{2}$ tot een fractie van de huidige emissie wordt teruggebracht. 
Evengoed duren de wetenschappelijke controverses voort. Het is zelfs de vraag of deze ooit kunnen worden beslecht. De aarde vormt immers een uniek systeem dat niet experimenteel of modelmatig is na te bootsen. Derhalve kan in principe nooit worden uitgesloten dat bepaalde terugkoppelingen van het uiterst complexe systeem onbekend zijn en derhalve aan de gehanteerde modellering ontsnappen. De empirische basis voor de uitspraken is echter sinds 1990 gaandeweg versterkt, en er bestaat nu geen twijfel meer over het feit van de opwarming zelf als over de mate van uitstoot van broeikasgassen en hun stijgend aandeel in de atmosfeer. Het probleem betreft met name de causaliteit van de gebleken correlatie tussen beide reeksen. Het IPCC heeft zich grote moeite getroost het inzicht in het klimaatsysteem te verfijnen en alternatieve hypothesen tot hun recht te laten komen, zoals natuurlijke fluctuaties, de invloed van vulkanische activiteit en de periodiciteit van zonneactiviteit. Deze openheid heeft geleid tot verdere verfijning van de modellen en hun empirische fundering; tot op heden bleken theorieën die op andere verklaringen dan menselijke activiteit wezen geen stand te houden.

De huidige zeer scrupuleuze werkwijze van het IPCC is niet verwonderlijk. De aanvaarding door de wereldgemeenschap van een probleem dat zeer ingrijpende oplossingen zou vergen, stelt zeer hoge eisen aan de onderbouwing. Met de gekozen werkwijze, waarin steeds meer aandacht aan de onzekerheden wordt besteed, heeft het IPCC dan ook groot gezag weten te verwerven, ook al is er kritiek geweest op de wijze waarop de wetenschappelijke informatie in de rapportages is gereduceerd tot politiek 'behapbare' proporties. De geboden informatie confronteert de wereld met de noodzaak tot een ingrijpende koersverandering van een welvaartsontwikkeling die breed wordt geambieerd en waarvoor veel lichten op 'groen' staan. Immers, verdere vergroting van de welstand vormt in de westerse wereld de dominante drijfveer, evenals vermindering van de armoede in de rijk bevolkte ontwikkelingswereld. Hiertoe wordt voornamelijk fossiele energie ingezet, die op ruime schaal beschikbaar is, waarvan de technische winbaarheid toeneemt en dat bovendien tegen een prijs waar alternatieve energiebronnen niet tegen kunnen concurreren. Consumptiepatronen worden bij een stijgende welvaart bovendien steeds energie-intensiever; de geboekte winst door verbetering van de energie-efficiëntie per eenheid product wordt stelselmatig vergaand overtroffen door volume-effecten.

Tegen deze achtergrond vormt de beleidsontwikkeling een enorme opgave. Deze opgave wordt nog vergroot door de afwezigheid van een jurisdictie op hetzelfde schaalniveau als waarop het probleem zich voordoet. Het doen aanvaarden van de noodzaak van ingrijpen kan nog niet worden gerechtvaardigd door een sluitende wetenschappelijke bewijsvoering. Ondanks enorme inspanningen komt de wetenschap vooralsnog niet verder dan de - zoals gesteld niet onomstreden kwalificatie 'waarschijnlijk', zij het dat de in het geding zijnde negatieve consequenties zeer groot zijn, hoewel ze regionaal uiteenlopen en voor sommige 
regio's ook positief uitvallen. Voor deze situatie van plausibele, maar niet definitief vaststelbare risico's kan voor de rechtvaardiging van beleid een beroep worden gedaan op het voorzorgsbeginsel. Dit beginsel is weliswaar omstreden, maar er is desalniettemin een juridische status aan verleend in het Europese en Nederlandse recht. Het is omstreden om een aantal redenen. Ten eerste omdat de toepassing ervan niet uitsluit dat er zeer hoge kosten worden gemaakt op achteraf onjuiste gronden. Ten tweede omdat de gevreesde risico's innovaties kunnen belemmeren die achteraf grote baten opleveren. Ten derde omdat het beginsel onvoldoende recht doet aan de risico's die inherent zijn aan de huidige situatie. Ten vierde suggereert het dat een risicoloze maatschappij realiseerbaar is. Ten slotte is er het argument dat het voorzorgsprincipe tactisch kan worden ingezet voor feitelijk protectionistische overwegingen (bijv. Majone 2002; Hanekamp 2002). Het beginsel is nogal multi-interpretabel, maar de kern wordt gevormd door de erkenning dat beleidshandelen geboden kan zijn in situaties waarin geen volstrekte zekerheid bestaat over de oorzaak-gevolgketens, maar wel een sterk vermoeden bestaat van negatieve gevolgen voor mens en milieu. Zo stelt de WTO in artikel 5 lid 7 dat het lidstaten is toegestaan maatregelen te nemen die niet worden gesteund door een risicoanalyse ingeval de wetenschappelijke onderbouwing ontoereikend is, maar alleen voorlopig. Het gaat hier om 'toestaan', hetgeen begrijpelijk is vanuit het WTO-perspectief van handelsliberalisatie. Principe 15 van de Verklaring van Rio van 1992 is prescriptief, evenzeer begrijpelijk vanuit haar milieuperspectief:

"In order to protect the environment, the precautionary approach shall be widely used by States according to their capabilities. Where there are threats of serious and irreversible damage, lack of full scientific certainty shall not be used as a reason for postponing cost-effective measures to prevent environmental degradation."

In het EG-Verdrag is het voorzorgsbeginsel opgenomen, naast het preventiebeginsel en het beginsel van 'de vervuiler betaalt', maar niet gedefinieerd. De Europese Commissie stelt echter dat toepassing gerechtvaardigd is wanneer er "reasonable grounds [are] for concern that the potential dangerous effects on the environment, human, animal or plant health are inconsistent with the chosen level of protection". Voorts wordt een plicht tot afweging vooraf geformuleerd:

"Indien ten gevolge van toetsbare kennis een redelijk vermoeden bestaat dat een bepaalde handeling een ongewenst gevolg heeft voor mens of milieu, maar het causale verband tussen handeling en gevolg niet met volledige zekerheid kan worden aangetoond, dan is degene die over het toelaten of verrichten van de handeling beslist verplicht een controleerbare afweging te maken of het risico al dan niet genomen kan worden of het gevolg zal optreden.” (EC 200o)

Weinigen zullen ontkennen dat de bevindingen van het IPCC het karakter hebben van een 'redelijk vermoeden' ten aanzien van de mogelijkheid van klimaatverandering en ten aanzien van ernstige negatieve gevolgen ervan. Derhalve is de toepassing van het voorzorgsbeginsel rechtmatig te noemen. Dit heeft zijn neerslag gekregen in het Klimaatverdrag van de VN (1992) en in het verlengde hiervan 
het Kyoto-Protocol (1997), en de in dat kader via bijeenkomsten in Den Haag en Bonn uiteindelijk in Marrakech in 2001 bereikte politieke respectievelijk juridische overeenkomst over concrete reductiepercentages voor de periode 2008-2012 en het controle- en sanctiemechanisme (het in 2012 blijkende tekort moet in de volgende verplichtingenperiode met een factor 1,3 worden goedgemaakt). De afspraken betreffen als eerste stap een reductie tot het mondiale emissieniveau van 1990. Door de weigering van de Verenigde Staten mee te doen en door de concessies die zijn gedaan om landen als Japan en Rusland over de streep te halen (het meetellen van de zogeheten sinks), wordt echter gevreesd dat de wereld in 2010 eerder een aanzienlijke stijging dan een daling tot het emissieniveau van 1990 te zien zal geven (Den Elzen en De Moor 2001). Dit betekent niet dat het Kyoto-Protocol geen effect zal hebben; zonder protocol zou de emissie van broeikasgassen nog hoger uitvallen.

Bovendien betekent het protocol een belangrijke doorbraak ten aanzien van de lang bestaande tegenstelling tussen Noord en Zuid. Feitelijk gaat het hier om een impliciete toedeling van emissierechten. Door het westen is namelijk aanvaard dat de ontwikkelde wereld het leeuwendeel van de reductie voor haar rekening neemt, dat de ontwikkelingswereld niet in haar groeiambitie wordt belemmerd en door het westen zal worden bijgestaan in het verbeteren van de energie-efficiëntie en het verminderen van de uitstoot van broeikasgassen en - voor de minst ontwikkelde landen - het westen bijstand zal verlenen in het hoofd bieden aan de gevolgen van klimaatverandering. Hiertoe zijn de zogenoemde flexibele Kyotoinstrumenten van belang, die als oogmerk hebben dat de emissies worden teruggedrongen tegen de laagste kosten ('Clean Development Mechanism', 'Joint Implementation' en 'International Emission Trading'). Uiteindelijk is overeengekomen dat de rijke landen een substantieel deel van hun reductieverplichting via deze mechanismen in het buitenland mogen realiseren. Nederland zal dit voor de helft van de verplichting doen. Niet alleen is dit aantrekkelijk uit het oogpunt van kosteneffectiviteit; het vermindert voor westerse landen ook de zeer lastige opgave om substantiële verandering aan te brengen in hun zeer energie-intensieve productie en consumptie. De bedoeling was dat tijdens de Wereldtop over Duurzame Ontwikkeling in Johannesburg voldoende landen (55) het verdrag zouden hebben geratificeerd, teneinde het protocol erna in werking te kunnen laten treden. Dat is niet uitgekomen; naar verwachting zal het in 2003 zover zijn.

Gezien de nog immer bestaande wetenschappelijke onzekerheden, mede door de Verenigde Staten aangevoerd als argument om van deelname af te zien, is de aanvaarding door een belangrijk deel van de wereldgemeenschap van de noodzaak tot een overeenkomst te komen opmerkelijk. Het gewicht van de gevolgen zal vele landen ertoe hebben gebracht het voorzorgsbeginsel hier ontvankelijk te verklaren, zoals ook in Nederland het geval is geweest (zie hoofdstuk 5). De grote druk van de kant van de milieubeweging heeft hierbij eveneens een belangrijke rol gespeeld. Met het in werking treden is de rechtmatigheid gegeven. Met de effectiviteit ligt het echter geheel anders. Afgemeten aan de langetermijnnoodzaak de emissie van $\mathrm{CO}_{2}$ met 60 à 90 procent te verminderen, betreft het akkoord 
slechts een eerste, zeer kleine stap. Maar dit was het maximaal haalbare. Het uiteindelijk doel, het voorkomen van antropogene klimaatverandering, zal als de IPCC-veronderstellingen juist zijn, niet worden bereikt. De 'grote' effectiviteit zal derhalve hooguit betrekking hebben op het temporiseren van het proces, opdat aanpassing aan de effecten mogelijk is. Met de overeenkomst zal bovendien de aandacht verschuiven naar de 'kleine' effectiviteit, namelijk de mate waarin de Kyoto-doelstellingen worden gehaald, en de efficiëntie waarmee dit het geval is. Daar is ook alle aanleiding toe, want zelfs de beperkte emissiereductiedoelstelling ten aanzien van broeikasgassen vormt gezien de ervaringen al een formidabele opgave.

Dit laatste geldt eveneens voor Nederland. Ondanks het reeds sinds 1989 bestaande beleid is ons land er nimmer in geslaagd de gestelde en steeds weer uitgestelde reductiedoelen te bereiken, in weerwil van een behoorlijke verhoging van de energie-efficiëntie. De hogere economische groei dan verwacht en de lage grondstofprijzen zijn hier debet aan. Zelfs in 2001 - met een lage economische groei - heeft de $\mathrm{CO}_{2}$-emissie nog een stijging te zien gegeven (RIVM 2002b). De Milieubalans 2001 van het RIVM toont grote twijfels over de haalbaarheid van de Nederlandse Kyoto-verplichting, te weten een reductie in 2008-2012 van de emissies met zes procent ten opzichte van 1990. Dit doel kan alleen worden gehaald als alle voorgenomen reductiemaatregelen inderdaad worden genomen en als de economische groei beperkt blijft (RIVM 2001a: 24). Beperking van de economische groei zal echter niet snel het oogmerk van beleid worden; alleen de conjunctuur zou hiervoor nolens volens kunnen zorgen. Het daadwerkelijk implementeren van alle beleidsvoornemens blijkt bovendien een zware voorwaarde; zowel bij de effectiviteit van het gehele voorgestelde pakket als van onderdelen ervan voor de binnenlands te realiseren reductie plaatst de Algemene Rekenkamer (2002) grote vraagtekens. Het Nederlandse beleid kent twee pijlers: emissiereductiebeleid en energiebesparingsbeleid. Naast subsidies en voorlichting en enige heffingen vormen vooral convenanten een hoofdbestanddeel van de instrumentering. Blijkens de Evaluatienota klimaatbeleid (2002) toonde het tweede kabinet-Kok zich echter optimistisch over de effectiviteit van het pakket voorgestelde en in uitvoering zijnde maatregelen. Bovendien is er nog een reservepakket aan maatregelen ontwikkeld, dat bij tegenvallende resultaten kan worden ingezet.

Een aan het verleden te ontlenen gegeven is dat met name financiële instrumenten die direct betrekking hebben op gekoesterd gedrag grote maatschappelijke en politieke weerstand oproepen, hoewel ze theoretisch de grootste effectiviteit hebben. Het kabinet-Balkenende handhaaft de Kyoto-verplichtingen, maar toont weinig animo voor sommige van de bestaande instrumenten uit deze categorie. Het emissieverhogende effect hiervan wordt gecompenseerd door het langer openhouden van de kerncentrale in Borssele (Ministerie van VROM 2002). Opnieuw geldt hier dat doelstellingen in abstracto breed kunnen worden gedeeld, maar dat de haalbaarheid van het daartoe benodigde instrumentarium iets geheel anders is. 
Naast de lidstaten heeft evenwel ook de EU de overeenkomst geratificeerd waarmee het partij bij het Kyoto-Protocol is geworden. De Unie heeft zich gecommitteerd aan een reductie van acht procent tot 2008-2012, welke opgave is doorvertaald naar ieder van de lidstaten. Bij de bepaling van emissierechten is rekening gehouden met de verwachtingen per lidstaat met betrekking tot economische groei, samenstelling van de energiemix en de industriële structuur (Beschikking van de Raad van 25 april 2002). De reductieverplichtingen van de lidstaten zijn derhalve niet alleen onderhevig aan het controle- en sanctiemechanisme van het protocol, maar eveneens aan dat van de Unie. De EU heeft hiertoe in het kader van het European Climate Change Programme zelf een aantal gemeenschappelijke en gecoördineerde maatregelen ontworpen, waaronder een intern systeem van emissiehandel. Dit systeem maakt voor de lidstaten een meer efficiënte, dat wil zeggen kosteneffectieve realisering van de Kyoto-verplichting mogelijk.

Dit gebied vormt dus opnieuw een voorbeeld van afnemende nationale autonomie. Dit kan de effectiviteit en efficiëntie ten goede komen. Tegelijk biedt dit Nederland immers ook een betere mogelijkheid om zijn reductiedoelstelling te behalen via het flexibele instrumentarium dat in het Kyoto-Protocol is overeengekomen. Maar evenals bij de in paragraaf 4.3 besproken richtlijnen behoort terwille van de haalbaarheid lankmoedigheid ten aanzien van de doelen - waardoor het energiebeleid het achterliggende decennium werd getypeerd - nu niet langer meer tot het reguliere politiek-bestuurlijke arsenaal. Het beschikbare sanctie-instrumentarium dwingt tot een veel zwaardere beleidsinzet.

\subsubsection{CHLOORHOUDENDE VERBINDINGEN}

De discussie omtrent de risico's van chloorhoudende verbindingen speelt zich veel meer dan het klimaatprobleem af in de luwte van de publieke belangstelling. De waarneembaarheid van de problemen is voor leken zeer beperkt. De discussie wordt dan ook hoofdzakelijk gevoerd door chemische industrie, milieubeweging, overheid en onderzoekers. Desalniettemin gaat het hier om een zeer weerbarstig milieuprobleem, dat is behept met grote kennisonzekerheden en waarbij omvangrijke belangen op het spel staan. De chloorchemie vertegenwoordigt een groot economisch en industrieel belang.

Vanwege hun grote elektronegativiteit gaan chlooratomen gemakkelijk bindingen aan met andere stoffen, wat soms leidt tot stabiele en moeilijk afbreekbare stoffen en materialen, met name bij de organochloorverbindingen. Voor veel stoffen en materialen zijn dit gewenste eigenschappen: in naar schatting twee van de drie producten die de consument dagelijks gebruikt komt het element voor, en als het er niet in voorkomt, dan is het wel als hulpstof gebruikt bij de vervaardiging van die producten. Uit het oogpunt van het milieu gaat het echter om een zeer problematische grondstof. Chlorering van organische verbindingen leidt in veel gevallen tot een vergroting van de oplosbaarheid van deze verbindingen in vetten en oliën en tot vergroting van hun toxiciteit (Thornton 200o). Maar juist diezelfde eigenschappen - reactiviteit van chloor, stabiliteit, oplosbaarheid 
in vet en toxiciteit van chloorhoudende verbindingen - kunnen grote gevolgen hebben in een niet-gecontroleerde omgeving, zoals het milieu. De milieurisico's van producten waarin chloor is verwerkt hebben daarom de zorg van de milieubeweging gewekt. Er is een constant risico van industriële calamiteiten bij de productie en het transport van chloorgas en bij de verwerking van chloor in halfen eindfabrikaten. Enerzijds gaat het daarbij om een reeks van stoffen en materialen die op betrekkelijk grote schaal werden en worden gebruikt: desinfectie- en schoonmaakmiddelen, PVC en enkele andere kunststoffen, CFK's, oplosmiddelen en bestrijdingsmiddelen. Anderzijds gaat het om het risico van vorming en verspreiding van chloorhoudende verbindingen met persistente, toxische en bioaccumulerende eigenschappen (PTB's) uit productie, gebruik en afbraak van deze stoffen en materialen (chloormicro's).

De eigenschappen van chloor vormen onderwerp van een langlopend en sterk gepolariseerd debat tussen vooral de milieubeweging en de industrie over vooren nadelen: chloor is zowel getypeerd als 'de waterpomptang van de chemicus' alsook als 'hulpje van de duivel' (Rozendaal 1995). Ondanks door de overheid in gang gezet beleid om de grootste risico's van transport en gebruik van chloor en chloorverbindingen te beperken door middel van veiligheidsvoorschriften, gebruiksverboden en beperkende maatregelen voor een aantal specifieke organochloorverbindingen, staan nog steeds de in de jaren negentig ontwikkelde slogans 'chloor de wereld uit' en 'chloor is noodzakelijk voor duurzaamheid' tegenover elkaar. In het recente verleden is een aantal initiatieven genomen om de patstelling in het debat over risico's te doorbreken. Voorzover er al, soms ook door de overheid gestimuleerd, een debat op gang kwam, heeft dit echter het karakter gehouden van een 'dialoog tussen doven' (Van Eeten 1999).

Aanvankelijk concentreerde de discussie zich op specifieke, risicovolle stoffen. Een reeks van stoffen is in de loop der jaren verboden (zoals DDT, drins, PCP, open toepassingen van PCB's, CFK's), worden uitgefaseerd (chloorhoudende schoonmaak- en oplossingsmiddelen, een aantal bestrijdingsmiddelen), of zijn gebonden aan strenge emissienormen (dioxines). De basis voor regulering werd en wordt gevormd door een schatting van de risico's voor mens en milieu per verbinding. Dit uitgangspunt, dat is ontwikkeld in de nota Omgaan met risico's (Ministerie van VRom 1989), is in 1989 door de Tweede Kamer bekrachtigd. Hetzelfde jaar vormde echter voor de milieubeweging, die zich tot ver in de jaren tachtig eveneens richtte op afzonderlijke stoffen, transport en verbranding, echter een keerpunt vanwege onder meer de dioxine-affaire in de Lickebaertpolder. Deze gaf een impuls aan het succes van acties om PVC uit verpakkingsmateriaal te weren. Bovendien attendeerde deze affaire - naast andere indicaties - op de stofeigenschappen van chloor, zoals de mogelijkheid tot vorming van persistente, bioaccumulerende en toxische verbindingen in niet-gecontroleerde omgevingen. In het rapport Van keukenzout tot gifcocktail (Berends en Stoppelenburg 1990) werd een chloorstrategie uitgedacht. De boodschap was: 'chloor de wereld uit'. Deel van de motivering vormde ook het heersende gebrek aan kennis over aard, vorming, verspreiding en risico's van een groot aantal chloorhoudende verbin- 
dingen. Juist deze onbekendheid en onzekerheid noopten er volgens de milieubeweging toe het beleid te baseren op het voorzorgsbeginsel in plaats van op een risicobenadering; vandaar de phasing out-strategie.

Deze tegenstelling tussen de milieubeweging, die zich baseert op het voorzorgsbeginsel, en de industrie, die bereid is tot vergaande maatregelen voorzover risico- en levenscyclusanalyses daar aanleiding toe geven, is tot op heden blijven bestaan. Conflicten over de te aanvaarden probleemdefinitie en de haalbaarheid van de te kiezen oplossingsrichting hangen derhalve nauw samen met het te hanteren rechtsbeginsel: preventie op grond van inzicht in risico's of voorzorg vanwege onzekerheid. De overheid heeft verschillende pogingen gedaan om de partijen dichter bij elkaar te brengen, met name door onderzoek te bevorderen naar de betwiste onderwerpen. Uiteindelijk heeft het voorzorgsbeginsel toch een toepassingsbereik gekregen, zoals hierna zal blijken.

Vormden afzonderlijke stoffen aanvankelijk de invalshoek van alle partijen, gaandeweg zijn elementen van de zorgen van de milieubeweging over chloor in meer algemene zin deel gaan uitmaken van de onderzoeksagenda. Evident is dat met deze verbreding de tegenstelling tussen industrie en milieubeweging zich verdiepte: het moeten afzien van chloor zou een enorme omschakeling van de chemische industrie vergen. In 1989 startte AKzO een eigen campagne om het belang van chloor in de samenleving en de veiligheid en beheersbaarheid van de risico's te benadrukken. In 1990 maakte AKzo bekend dat de industrie bereid was een studie naar integraal beheer van de chloorketen uit te voeren, conform een van de actiepunten uit het NMP I. De in 1991 gepubliceerde VNCI/McKinsey-studie, waarbij industrie, overheid en deskundigen waren betrokken, resulteerde in een beoordelingssystematiek voor de afweging van milieugevaren van stoffen en materialen (VNCI 1991). De vraag stond centraal of en hoe de risico's van specifieke ketens van chloorhoudende producten beter onder controle konden worden gebracht. De industrie toonde een vergaande bereidheid belangrijke emissies te reduceren (kwik), productketens te sluiten (met name PVC in lange-levensduurtoepassingen) en het transport van chloor te verminderen door productie en verwerking bij elkaar te lokaliseren. Restemissies en kleine risico's werden echter tolerabel geacht. De milieubeweging, die formeel niet wilde participeren maar via een deskundige wel bij de studie betrokken was, reageerde negatief op de uitkomsten van de studie. Volgens Tukker (1999) was, voordat de studie van start ging, al duidelijk dat de risicobenadering van industrie en overheid, die in de studie eveneens werd gehanteerd, moeilijk viel te verzoenen met de voorzorgsbenadering van de milieubeweging. Met het beste risicomanagement zou volgens de milieubeweging immers niet het hoofd kunnen worden geboden aan mogelijke negatieve effecten van Ртв's voor mens en milieu. De kennis hieromtrent was weliswaar zeer gering, maar er waren wel aanwijzingen van hormoonverstoring bij dieren door chloormicro's en werden er ondanks alle verboden gechloreerde koolwaterstoffen aangetroffen in verschillende milieucompartimenten maar ook in menselijk vetweefsel, moedermelk en zaadcellen (Gezondheidsraad 1997; 1999). Onzekerheid vormde voor de milieubeweging derhalve geen reden om van beleid af te zien. 
De impasse dwong het ministerie van vrom een standpunt in te nemen over de vraag of er inderdaad een beleid noodzakelijk was dat zich specifiek richtte op chloor en alle chloorhoudende verbindingen. Op aandrang van de Vaste Kamercommissie van Milieu werd hiertoe in 1993 een strategische verkenning begonnen naar de mogelijkheden tot het dichten van de chloorketen in Nederland. Bij deze studie hield de milieubeweging zich opnieuw afzijdig; ditmaal gebeurde dit omdat in het onderzoek geen aandacht werd besteed aan alternatieven voor chloor. De in 1995 verschenen studie bracht 99 procent van de Nederlandse chloorketen in kaart en somde een aantal beleidsprioriteiten op. Het rapport gaf echter ook aan dat er ten aanzien van chloormicro's onzekerheden en kennislacunes bestonden. Emissiereducties zouden volgens de onderzoekers derhalve de milieuproblemen wel aanzienlijk kunnen verminderen, maar onduidelijk bleef hoe vervuilend de chloorproducerende industrie zou blijven. De toenmalige minister De Boer concludeerde evenwel dat er geen specifiek chloorbeleid nodig was, en dat de chloorproblematiek 'beheersbaar' was door middel van een elftal op knelpunten te richten acties. De minister insisteerde derhalve bij het gevoerde algemene stoffenbeleid en de risicobenadering daarbij uit de eerdere nota Omgaan met risico's, maar erkende wel dat het gebrek aan inzicht in het ontstaan van chloormicro's een kennisleemte vormde. Niet alleen de milieubeweging, maar ook de betrokken wetenschappers en de wetenschappelijke reviewcommissie vonden dat deze beleidsreactie geen recht deed aan de bevindingen. De kritiek had vooral betrekking op de omgang met het vraagstuk van de chloormicro's, en dit is sindsdien het belangrijkste strijdpunt gebleven. De argumenten van de milieubeweging kregen bovendien ondersteuning door het in 1992 in de Verklaring van Rio aangenomen voorzorgsprincipe en ook van een internationale conventie (Ospar 1992), waarvan Nederland partij is (Ministerie van v\&w), gericht op het elimineren van lozingen van РTB's. De onvrede met het regeringsstandpunt leidde tot informeel overleg tussen ministerie, Vaste Kamercommissie voor Milieu, industrie en milieubeweging. Dit resulteerde in het instellen van de Begeleidingsgroep Implementatie Acties Chloorketenstudie. Niet alleen kreeg deze tot taak de elf aangekondigde acties te monitoren, maar ook om onderzoek te instigeren naar de emissies van PтB's en hun milieugevolgen, om manieren te vinden om met verschillende uitgangspunten voor risicobeoordeling om te gaan, en eveneens alternatieven voor chloor te ontwikkelen. Uit dit overleg werden in 1999 de Stuurgroep Chloor en Alternatieven en het Onderzoeksprogramma Vervolgonderzoek Chloorketenstudie (OvOC) geboren. De milieubeweging participeerde aanvankelijk zowel in de Stuurgroep als in de begeleidingscommissie van het ovoc.

De Stuurgroep Chloor en Alternatieven werd in 2001 weer opgeheven, omdat het niet mogelijk bleek overeenstemming te bereiken over een methodiek voor het beoogde onderzoek. Het was een te ambitieuze poging om industrie en milieubeweging, zonder dwang of druk vanuit de overheid, in gezamenlijk overleg en met explicitering van de waardeoriëntaties een methodiek te laten ontwikkelen voor de beoordeling op duurzaamheidaspecten (d.w.z. milieu- én sociaal-economische aspecten) van chloorhoudende en chloorvrije producten en inzicht te 
verwerven in de eventuele omschakelingsproblematiek. Met het bespreekbaar worden van alternatieven voor chloor werd de agenda van de milieubeweging gehonoreerd. In eerste instantie werd gepoogd de reguliere risicosystematiek te verbreden door de milieubeoordeling te baseren op de levenscyclusanalyse van alternatieven ten aanzien van risico's voor de menselijke gezondheid. Hoewel derhalve de gehanteerde methodiek via deze uitbreiding werd verbeterd, konden de partijen het toch niet eens worden over de weging van de onderscheiden criteria. "Meer weten [zal] de verschillen van inzicht niet [...] doen verminderen", stelde de stuurgroep naar aanleiding van het mislukken (Stuurgroep Chloor en Alternatieven 2001), omdat partijen verschillende waarde hechtten aan de additionele criteria, en omdat er geen wetenschappelijke keuze mogelijk was tussen de respectievelijke afwegingskaders. Vond de industrie dat het aan de milieubeweging was haar claims ten aanzien van vermeende risico's te onderbouwen, de milieubeweging weet het mislukken ook aan gebrek aan bereidheid van de industrie uitkomsten te accepteren waarin alternatieven voor chloorhoudende producten beter uit de bus zouden komen. Hoe dit ook zij, het verschil in belang zal de perceptie zeker hebben gekleurd. Juist omdat de inschatting van het belang van milieugevaren én van onzekerheden zozeer verschilde, was volgens de milieubeweging een actieve overheid die optreedt als scheidsrechter onmisbaar.

Evenals bij Schiphol toont derhalve ook deze casus de beperkingen van een multi-actorbenadering ingeval van sterk uiteenlopende waardeoriëntaties. Hoezeer ook is gepoogd participatiestructuren te vinden waarin de contestanten met elkaar konden debatteren over interpretatiekaders, probleemdefinities en oplossingsrichtingen, de stofgerichte risicobenadering die zich concentreerde op het kenbare deel bleek vooralsnog onverzoenbaar met de voorzorgsbenadering die zich juist op de resterende onzekerheden concentreerde. De stuurgroep deed zelf geen onderzoek. Maar het staat nog open of nader onderzoek in staat zal zijn de bestaande kloof te overbruggen, omdat volstrekte zekerheid over onschadelijkheid in principe wel maar op praktische gronden moeilijk bereikbaar is. In termen van Van Asselt (200o) gaat het hier bij uitstek om een voorbeeld van structurele onzekerheid. Een stofgerichte onderzoeksbenadering zou kennis per stof moeten opleveren over (1) emissies, gedrag en effecten van chloormicro's; (2) de beheersbaarheid van stoffen en productieprocessen; en (3) de mate van blijvendheid van eventuele schade aan mens en milieu. Het aantal stoffen dat in het geding is, is echter buitengewoon groot, en de situaties waarin zich effecten kunnen voordoen zijn zeer divers. Bovendien is er het vraagstuk van het effect van combinaties van stoffen.

Toch vormt met name het eerstgenoemde onderzoekspunt de taakstelling van het bovengenoemde ovoc. De doelstelling is enerzijds vast te stellen of en in welke mate PTB's of groepen van РTB's uit de chloorketen in het milieu terechtkomen en anderzijds een bijdrage te leveren aan het vaststellen van hun milieubezwaarlijkheid. Van belang hierbij is ook dat wordt onderzocht in hoeverre de aangetroffen schadelijke concentraties van chloormicro's een recente antropogene oorsprong hebben of van ouder datum zijn. In het laatste geval zou immers de chloorketen nu 
toereikend zijn gesloten. De milieubeweging, die nog steeds deelneemt aan de begeleiding van het onderzoek, heeft ook met dit onderzoek erkenning gekregen van haar zorgen; het is immers een eerste poging om ten aanzien van het centrale onderwerp van de bestaande controverses feitenkennis te ontwikkelen.

Ook de meest recente beleidsontwikkelingen wijzen in deze richting. Het tweede kabinet-Kok heeft een nieuw stoffenbeleid in gang gezet. De Strategienota Omgaan met stoffen (Ministerie van VROM 2001b) geeft aan dat het huidige instrumentarium - risicomanagement van individuele stoffen - niet doeltreffend is. Er worden te veel stoffen geproduceerd en gebruikt die geen adequate risicobeoordeling hebben ondergaan. De voortgang op dit terrein betreft enkele tientallen stoffen per jaar, terwijl het aantal nog te beoordelen stoffen 100.000 bedraagt. Bovendien groeit het aantal nieuwe stoffen en toepassingen snel. Hiernaast blijft het vóórkomen van persistente en bioaccumulerende stoffen in natuurgebieden en organismen en hun mogelijke effecten een bron van zorg. Het voortduren van de huidige situatie kan bijdragen aan een afbrokkelend vertrouwen van burgers in de bescherming van gezondheid en milieu door overheid en beleid, zo stelt de nota. Hiermee wordt derhalve erkend dat de beperkte effectiviteit dus ook de aanvaardbaarheid in het geding kan brengen.

Het nieuwe stoffenbeleid eist van het bedrijfsleven een categorisering naar de mate van gevaarlijkheid, en reguleert voor deze categorieën de aard van de toegestane toepassing. Stoffen die vooralsnog niet afdoende zijn te karakteriseren mogen niet in het milieu of in producten terechtkomen, tenzij binnen een bepaalde periode gegevens beschikbaar komen die aantonen dat deze stoffen geen of nauwelijks gevaar of risico's veroorzaken (no data, no market). Op deze wijze wordt het voorzorgsbeginsel ingeval van voortdurende onzekerheid onderdeel van de regelgeving. Het is voorts aan het bedrijf de noodzakelijke informatie te vergaren. Dat nu de bewijslast voor de (on)schadelijkheid bij de industrie wordt gelegd, is ook conform de opvatting van de Europese Commissie in het Witboek Strategie voor een toekomstig beleid voor chemische stoffen (EC 2001b). Voor de gehele implementatie is in het nieuwe stoffenbeleid een periode van twintig jaar voorzien. Deze lange periode en de fasering daarbinnen zijn noodzakelijk om recht te doen aan de uitvoerbaarheid van de voor de industrie ingrijpende taakstelling ten aanzien van noodzakelijke kennisgaring van gevaarkenmerken van stoffen, het afbouwen van het gebruik van bepaalde stoffen en het vinden en kunnen toepassen van acceptabele substituten.

Hiermee lijkt ten langen leste zicht te zijn ontstaan op een oplossing van de chloorcontroverse. In zekere zin hebben alle partijen iets gewonnen en verloren. De aanpak via risicobeheersing is gehandhaafd, maar de mogelijkheid van phasing out van individuele stoffen op grond van het voorzorgsbeginsel heeft ook erkenning gevonden. Er wordt geen specifiek op chloor gericht beleid gevoerd. Dit doet recht aan het argument van de industrie dat niet alle chloorhoudende verbindingen even risicovol zijn, en ook niet-chloorhoudende verbindingen РТВeigenschappen kunnen hebben. In het nieuwe beleid wordt evenwel de mogelijk- 
heid opengehouden dat van een in principe op grond van gevaarklasse geboden verbod van een stof afgeweken kan worden op grond van bijvoorbeeld 'dringende ernstige maatschappelijke verstoring' (Ministerie van VROM 2001b: 9). Ook de vaststelling van de precieze klassengrenzen, criteria en meetmethoden kan de scherpste kantjes ervan afhalen.

In de Tweede Kamer blijkt brede steun voor de nieuwe aanpak te bestaan, zij het dat de verhouding tot het door de EU te voeren stoffenbeleid een punt van zorg is, evenals de publieke transparantie, uitvoerbaarheid, handhaafbaarheid en geheimhouding wegens commercieel belang. Ook de milieubeweging heeft zich, ondanks de nodige reserves, met de nota ingenomen getoond. Experimenten met verschillende modellen van samenwerking binnen het bedrijfsleven om de benodigde gegevens boven tafel te krijgen, worden ondernomen om meer zicht te krijgen op uitvoerbaarheid en handhaafbaarheid. Zo toont deze casus bij uitstek hoezeer gedurende het afgelopen decennium de pogingen om een antwoord te vinden op vragen van aanvaardbaarheid, haalbaarheid, rechtmatigheid en effectiviteit tot het eind toe - als daarvan tenminste te spreken valt - verknoopt zijn geweest. Pogingen om binnen het risicobeheersingsparadigma tot een alle partijen omvattende participatie te komen, hebben aanvankelijk schipbreuk geleden. Er is pas samenwerking ontstaan toen het paradigma van de milieubeweging - dat zij ook pas gaandeweg beter heeft kunnen articuleren maar waarvoor zij zich wel heeft kunnen beroepen op een internationaal erkend rechtsprincipe heeft geresulteerd in een expliciet daarop gerichte onderzoeksagenda (OvOC). Ook deze casus laat - zoals gezegd - zien dat waar de paradigma's zover uit elkaar liggen als hier het geval is geweest, conflictoplossing niet zonder overheidsingrijpen kan. De rol van scheidsrechter, zoals de milieubeweging heeft aangegeven, is hiervoor een te zwakke aanduiding. De casus betreft immers een onderwerp waar de publieke belangen die in het geding zijn, een eigen overheidsverantwoordelijkheid rechtvaardigen. Waar een scheidsrechter 'slechts' de regels handhaaft, nopen deze belangen dat normen worden ontwikkeld.

\subsection{LESSEN EN VRAGEN}

\subsubsection{MOEIZAME BELEIDSVORMING}

Uit het voorgaande blijkt dat geen van de onderzochte casussen een gestroomlijnd verloop van de beleidsontwikkeling te zien heeft gegeven. In alle gevallen is het een moeizame worsteling om tot een grosso modo aanvaardbaar, haalbaar, effectief en rechtmatig beleid te komen. Er is geen sprake van een pro-actieve overheid, eerder doemt het beeld op van een benarde overheid. Deze komt pas goed in beweging onder invloed van grote druk, in eigen land door acties van bevolking en milieubeweging, of door dwingende internationale regelgeving. Maar dusdoende loopt zij op tegen eveneens zwaarwegende belangen. Waar toch - uit het oogpunt van milieu - van pro-activiteit sprake is, is de overheid zich niet 
bewust van enigerlei implementatielast (Vogelrichtlijn), of overschat zij de maatschappelijke aanvaardbaarheid van het doel en de haalbaarheid van het ingezette instrumentarium (Nitraatrichtlijn) of de effectiviteit van het grotendeels op overtuigen gebaseerde 'zachte' instrumentarium (voorlichting, $\mathrm{CO}_{2}$-beleid).

Geen van de zes casussen kent of kende eenvoudig te identificeren win-winoplossingen, waarmee alle betrokken partijen gemakkelijk zouden kunnen instemmen. Dit vormt voor de overheid natuurlijk een moeilijke situatie. Tenslotte vergt iedere maatregel een minimum aan algemene instemming om uitvoerbaar en handhaafbaar te zijn. Maar het is wel opvallend dat in verschillende casussen de overheid een zekere partijdigheid niet vreemd leek te zijn. Dit geldt voor drie casussen: Rijnmond, Schiphol en chloor. In beide eerstgenoemde casussen uitte dit zich in een langdurig gedogen van overtredingen van de regels door industrie respectievelijk luchthaven, bij de chloorcasus door aan te sluiten bij de risicobenadering van de industrie. Het zijn voorbeelden van een zekere regulatory capture, waarbij een van de partijen een relatief sterke invloed heeft op de overheidsregelgeving en -handhaving. Zorgen omtrent economie, werkgelegenheid en het industrieel klimaat zijn natuurlijk volstrekt legitiem, maar het vervolgens oogluikend toestaan van stelselmatige overtredingen van gestelde regels of het negeren van bepaalde risico's komt het maatschappelijke vertrouwen in de overheid niet ten goede. Grote onzorgvuldigheid bij het naleven door de overheid zelf van overeengekomen procedures tast dat vertrouwen nog verder aan. Wellicht dat deze selectieve houding ook de achtergrond vormt van de voorkeur voor zachte instrumenten ten behoeve van de $\mathrm{CO}_{2}$-problematiek. Zowel in Rijnmond als in Schiphol heeft de tekortschietende rechtshandhaving degenen die hiervan hinder ondervonden en hun zaakwaarnemers een belangrijk wapen in handen gegeven om de overheid tot actie te dwingen. Tegelijk attendeert dit erop dat het benarde karakter van de overheid deels ook vermijdbaar was geweest wanneer zij zich alle, in rechtsregels vervatte publieke belangen gelijkelijk had aangetrokken. Structuren waarin ook van countervailing participatie sprake is, kunnen de overheid voor deze eenzijdigheden behoeden, evengoed als het zorgvuldig naleven van overeengekomen procedures ten aanzien van derden de overheid voor het verlies aan vertrouwen kan behoeden.

\subsubsection{VOORTGANG IN DE BELEIDSVORMING}

Ondanks dat zich, uit de aard van de problematiek, geen win-win-oplossingen voordeden en de materie zelf ook zeer weerbarstig is, heeft de beleidsvorming in alle casussen toch voortgang geboekt. De luchtkwaliteit in Rijnmond wordt gecontroleerd en gehandhaafd. Het nieuwe stelsel van milieunormen waar Schiphol zich aan dient te houden, is aanvaard evenals ingebruikneming van de vijfde baan. De provincie Noord-Holland houdt in haar ruimtelijk beleid al rekening met ruimtereservering voor een zesde en wellicht zelfs een zevende baan, waarbij het verrichte onderzoek er op duidt dat zo'n uitbreiding binnen de huidige geluidsnormen tot de mogelijkheden behoort en per saldo welvaartsvoordelen 
oplevert. Na enkele gerechtelijke uitspraken wordt de Vogelrichtlijn op nationaal niveau geïmplementeerd en wordt de speelruimte voor decentrale niveaus ingekaderd. De Nitraatrichtlijn heeft een nationale implementatie gekregen, waarvan de resultaten - hoewel ontoereikend - toch wijzen op geleidelijke verbetering. De internationale aanpak van broeikasgassen heeft met het Kyoto Protocol een verdragsbasis gekregen, en zal vermoedelijk binnenkort in werking treden. Met het nieuwe stoffenbeleid lijkt een doorbraak te zijn bewerkstelligd in de langlopende chloorcontroverse.

Met deze voortgang is niet gezegd dat de controverses rond al deze thema's eveneens tot een eind zijn gekomen. Maar in de dynamiek van probleemsignalering naar regulering lijkt bij verschillende casussen gaandeweg wel een zekere ont-radicalisering waarneembaar. Dit kan worden gezien als een resultante van de wisselwerking tussen kennis- en informatiegaring, beleidsnormering en maatschappelijke participatie. In eerste instantie is het veelal de wetenschap die problemen signaleert, terwijl maatschappelijke groepen in de bredere bewustwording een belangrijke rol spelen. Dit leidt nogal eens tot een scherpe en generaliserende polarisatie. Deze is niet alleen een gevolg van tactische processen, teneinde het probleem op de agenda te krijgen resp. daarvan weg te houden. In initiële situaties spelen enerzijds authentieke verontrusting als gevolg van onwetendheid (een goede voedingsbodem voor angsten) als bagatellisering anderzijds omdat men - naast eveneens gebrek aan kennis - de gevolgen van bepleite gedragsverandering niet kan overzien, beide een rol. Wanneer echter de contestanten elkaars agenda serieus gaan of moeten nemen en de kennisgaring daar ook op gericht wordt, lijken processen van nuancering en matiging op te gaan treden. Rijnmond - waar door alle actoren het belang van het milieu nog als het ware moest worden 'uitgevonden' - vormt hiervan een goed voorbeeld. De aanvankelijke probleemontkenning door de industrie heeft daar inmiddels plaatsgemaakt voor een zekere competitie in 'goed gedrag'. Zonder te suggereren dat de casus - in termen van de OESO - inmiddels eveneens 'groen' is, is ook ten aanzien van Schiphol opmerkelijk dat de oorspronkelijke, en sterk generaliserende posities in de discussie - die neerkwamen op voor of tegen uitbreiding - hebben plaatsgemaakt voor een politiek geaccepteerd stelsel van normen voor de milieukwaliteit, waarbinnen Schiphol zich vervolgens vrijelijk moet kunnen bewegen. De oordeelsvorming over de huidige problemen rond de geluidhinder speelt zich af binnen dit nieuwe kader. Bij het in werking treden van de Nitraatrichtlijn meenden vele agrariërs dat deze het boeren volstrekt onmogelijk zou maken, terwijl inmiddels gebleken is dat dit niet het geval is en zelfs in sommige milieucoöperaties boeren zelf verdere aanscherping van de normen voorstaan. Ook de chloordiscussie is lang getekend geweest door diametraal tegenover elkaar staande posities: 'chloor de wereld uit' versus 'chloor is noodzakelijk voor duurzaamheid', terwijl nu de gevaren erkenning hebben gevonden, maar eveneens is aanvaard dat niet alle verbindingen risicovol zijn. Het lijkt er derhalve op dat er tenminste ten aanzien van de onderzoeksagenda een modus is gevonden waarmee recht gedaan wordt aan vragen die vanuit beide paradigma's relevant zijn. 
In alle gevallen heeft deze ontradicalisering van de discussie en het bereiken van beleidsvoortgang veel tijd gevergd. Of dergelijke veranderingsprocessen sneller kunnen verlopen, is moeilijk te beantwoorden. Verandering van gedragspraktijken betreft immers ook cultuurverandering, waarin het meewegen van milieueffecten gaandeweg moet normaliseren. Het vergt ook grote investeringen, en daartoe te ontwikkelen technieken van de kant van het bedrijfsleven, en verandering van regels en bevoegdheden e.d. bij de overheid. Dit alles kost tijd, maar wel is opmerkelijk dat er stroomversnelling ontstaat wanneer internationale gremia hun invloed doen gelden. Dit effect is aanwijsbaar bij beide besproken richtlijnen en zal waarschijnlijk ook het $\mathrm{CO}_{2}$-beleid te zien gaan geven. Via de beproefde eigen beleidstraditie gaven in elk geval zowel het mestbeleid als het klimaatbeleid lange tijd maar weinig voortgang te zien.

\subsection{CONCLUSIE}

Dit hoofdstuk heeft een staalkaart aan benaderingen laten zien die in Nederland werden en worden gehanteerd om te komen tot de definitie en oplossing van milieuproblemen. In lang niet alle gevallen is het probleem inderdaad opgelost, maar in ieder geval lijkt de richting ervan langzamerhand duidelijk te zijn. Evenmin is gezien de fase waarin de verschillende casussen zich bevinden het antwoord op de vier kernvragen van goed beleid al in positieve zin te geven. Zo is nog allerminst duidelijk of het zich aandienende beleid ten aanzien van chloor, Schiphol, de Vogelrichtlijn en het Kyoto-Protocol inderdaad haalbaar is. In het geval van de Nitraatrichtlijn is het antwoord al wel duidelijk: Nederland is ondanks een verbetering niet in de opgelegde doelstellingen geslaagd.

De twee bronnen - kennis en participatie - voor het vinden van een antwoord op de vier vragen, hebben bij alle casussen een rol gespeeld, zij het dat het beroep erop van geval tot geval verschilt. De kennisvraag is in het geval van Rijnmond en de Vogelrichtlijn gemakkelijker te beantwoorden dan bij bijvoorbeeld Schiphol, chloor en klimaatverandering. In alle casussen is een vorm van het 'groene poldermodel' van belang geweest. Bij de beide Europese richtlijnen blijken echter grote tekortkomingen te bestaan in het terwille van de haalbaarheid proactief voice geven aan die groeperingen wier gedragsverandering juist het oogmerk van het nieuwe beleid is.

Het milieubeleid zal steeds meer betrekking krijgen op de wicked problemen, zoals het broeikasprobleem en de chloorproblematiek. Ze kennen, zoals bijvoorbeeld het waterprobleem en de biodiversiteit, vele onzekerheden, die vermoedelijk lang niet alle kenbaar zijn. De gevolgen spelen op lange termijn. Het beleid zal dus in veel mindere mate dan sommige van de besproken problemen gebruik kunnen maken van een breed gedeeld probleembesef. Bovendien spelen er grote belangen. De beleidsvoorbereiding speelt zich af op internationaal niveau. Daarin kan en moet Nederland een rol spelen, maar de invloed is vanzelfsprekend 
beperkter dan wanneer het gaat om nationale problematiek. De beleidsuitkomst zal derhalve minder voldoen aan de vier onderscheiden criteria van goed beleid dan wanneer deze - met veel vallen en opstaan - via louter nationale arrangementen en procedures totstandkomt. Tegelijk wordt de noodzaak van uitvoering van de aangegane internationale verplichtingen groter; de ruimte van iteratie tussen doel en middel wordt immers kleiner. Dit accentueert het toenemende belang van de scharnierfunctie van de nationale overheid tussen het nationale en internationale niveau, inclusief de hierbij in het voorgaande beschreven problemen van goed beleid. Het argument dat 'het moet' van Brussel is in een mondige samenleving niet langer toereikend. In de Brusselse onderhandelingen in te nemen standpunten dienen nationaal goed te zijn voorbereid, en bereikte resultaten moeten tijdig en grondig worden gecommuniceerd naar de betrokken delen van de samenleving. 


\section{PERSPECTIEF}

\subsection{INLEIDING}

\subsubsection{VAN OUDE NAAR NIEUWE MILIEUPROBLEMEN}

De casuïstiek in hoofdstuk 4 heeft naast relatieve successen ook een aantal zere plekken van het Nederlandse milieubeleid aan het licht gebracht. De hinderproblemen, hoe lastig en conflictueus ze ook zijn geweest, zijn in rustiger vaarwater terechtgekomen. In ieder geval heeft één casus (Rijnmond) een bevredigende aanpak gekregen, hoewel voortgaande monitoring en evaluatie noodzakelijk blijven om geen terugval door te maken. Dit succes wordt vaak toegeschreven aan de effectiviteit van interactie, overleg en veronafhankelijking van kennis - de primaire modi operandi van de Nederlandse beleidstraditie. De 'Brusselse kwesties' laten echter een ander beeld zien. Zowel bij de Europese Vogelrichtlijn als bij de Nitraatrichtlijn heeft de Nederlandse overheid belangrijke steken laten vallen bij de implementatie van 'harde' richtlijnen. Mogelijk is hier sprake geweest van een zekere 'polderblindheid' - een doorgeschoten fixatie op onderhandeling en overleg met maatschappelijke organisaties en andere private partijen - die het Nederlandse beleidsmakers bijna onmogelijk heeft gemaakt om contre coeur verticale regelstelling af te dwingen ten overstaan van convenanten. Weer heel anders is het beeld bij de twee problemen die alle aspecten in zich hebben van de nieuwe generatie van milieuproblemen: klimaatverandering en chloorhoudende verbindingen. Beide zijn met veel onzekerheden omgeven. Ze worden gekenmerkt door enerzijds wetenschappelijke controverses over oorzaak en gevolg, en anderzijds door hoog oplopende politieke meningsverschillen tussen de betrokken partijen en belangengroepen over de verdeling van de pijn van beleid.

De vraag die in dit slothoofdstuk centraal staat is wat nu, gegeven de lessen uit de casussen, de meest geschikte probleemhantering is voor deze nieuwe generatie van milieuproblemen. Een eerste kenmerk van deze problemen is dat zij niet primair lokaal van aard zijn, maar dat het gedrag van velen in het geding is. Een tweede kenmerk ervan is dat de effecten zich minder direct en duidelijk manifesteren dan bij de 'oudere' milieuproblemen het geval is, waarbij sprake is van zintuiglijk waarneembare hinder. Bij direct ervaren hinder zijn mensen en instellingen gemakkelijker bereid gedragsbeïnvloedende maatregelen te aanvaarden dan bij weliswaar aangezegde, maar onzichtbare problemen. De nieuwe problemen zijn daarmee problemen die moeten worden 'bedacht', geconceptualiseerd in de hoofden van mensen zonder dat zij er ervaringsverhalen bij hebben. Overheden staan voor de taak om maatregelen te nemen voordat de ernstige effecten zich manifesteren. In de reguliere beleidsvorming gaat het dus in beginsel om 'leren voor de fout uit': beleid dat is gericht op de preventie van rampen en andere grootschalige nadelige gevolgen. Die ongunstige effecten blijven daardoor onzichtbaar, hetgeen op het punt van kennisverwerking door burgers en draag- 
vlakverwerving voor overheidsbeleid ongekend hoge eisen stelt. Het drievoudig lastige van legitimatieverwerving voor beleid is hier bij uitstek dat de ernstige effecten (1) in de toekomst liggen, (2) zich deels vooral zullen manifesteren op ver weg gelegen plekken op de aarde (en dus om internationale verbondenheid vragen), en (3) zich wellicht helemaal niet zullen voordoen (wetenschappelijke onzekerheid, die enerzijds kan nopen tot voorzorg, maar anderzijds door partijen in het debat ook kan worden aangegrepen om geen maatregelen te nemen).

\subsubsection{OPBOUW VAN HET HOOFDSTUK}

Het zou onrealistisch zijn te pretenderen dat voor de omvangrijke nieuwe milieuproblematiek een kant en klaar recept kan worden aangereikt. Dit slothoofdstuk richt zich daarom op de gewenste manier van benadering en niet primair op directe beleidsaanbevelingen. Het betoog concentreert zich op de ontwikkeling van een nieuw beleidsperspectief voor de nieuwe en nog openstaande wicked problems die nog niet binnen de bestaande beleidskaders beheersbaar zijn gemaakt. Zij zijn primair object van nadere beleidsvorming. De raad probeert een aantal aandachtspunten te markeren voor het noodzakelijke conceptuele raamwerk voor die beleidsvorming. Deze aandachtspunten zijn met name verwoord in de slotconclusies van paragraaf 5.5. De daaraan voorafgaande paragrafen bespreken achtereenvolgens de rol van wetenschappelijke kennis (par. 5.2), het belang van participatie (par. 5.3) en de relatie tussen nationale en internationale beleidsvorming (par. 5.4). Hierna lichten we deze elementen nader toe. Daarbij komen ook de verbanden tussen die onderwerpen ter sprake.

\section{De rol van wetenschappelijke kennis}

$\mathrm{Bij}$ de nieuwe milieuproblemen ontbreekt het aan burgers en andere betrokkenen die directe overlast ervan ondervinden. Hun stuwende rol in de agendering van de problemen is afwezig. Daardoor spelen 'kennis', kennisinstituten en -instituties een extra belangrijke rol in het proces van bewustwording van de nieuwe generatie van milieuproblemen. Daarbij hoort ook de rol van (geprofessionaliseerde) plaatsbekleders van de burgers, zoals Greenpeace, Milieudefensie, Natuurmonumenten, Stichting Natuur en Milieu, Stichting Reinwater, enzovoort. Deze organisaties hanteren en verspreiden kennis en oefenen ook invloed uit op andere kennisinstituties. De rol van kennis en (on)zekerheid, alsmede de vermaatschappelijking van kennis, komen in paragraaf 5.2 aan de orde.

\section{Het belang van participatie}

Paragraaf 5.3 handelt over het belang van participatieprocessen. De gedachte achter deze zoekrichting is dat velen in de samenleving gaan 'meedenken' over de relevante problematieken, en dat dit niet beperkt blijft tot een wetenschappelijkbestuurlijke elite. Het bij uitstek lastige dilemma bij de nieuwe generatie milieuproblemen is dat die wel velen raken, maar eerder sluipenderwijs en op termijn dan direct zintuiglijk waarneembaar. Er vallen geen schapen om of iets van dien aard. Dit betekent dat burgers, en hun plaatsbekleders, op andere manieren in beweging moeten worden gebracht. 


\section{De relatie tussen nationale en internationale beleidsvorming}

Paragraaf 5.4 handelt over de (milieu)beleidsvorming in EU-verband en op wereldschaal. Cruciaal voor het effectief aanpakken van de nieuwe problemen is de match die wordt gemaakt tussen de organisatie van de kennisinbreng en de politieke (nationale en internationale) besluitvorming. Het relatieve succes van de in hoofdstuk 4 behandelde Nederlandse casussen is terug te voeren op de iteratieve cumulatie van kennis door interactie, samen met de verwerving van commitment aan de gevonden oplossingen. Maar, zoals de Europese casussen hebben laten zien, staat deze nationale beleidsstijl op gespannen voet met legalistische, op de interne markt geënte communautaire besluitvorming in de EU. Ligt het nu voor de hand om EU-besluitvorming en andere internationale milieuafspraken te horizontaliseren naar het Nederlandse bestuursmodel? Een dergelijke keuze heeft wel een prijs: nationale beleidsvrijheid om oneerlijke concurrentie te mitigeren wordt verticaal ingeperkt. Of moet de ruimte voor de iteratie tussen doelen en middelen op nationale schaal juist pro-actief worden gebruikt om internationale leerprocessen te stimuleren, die kunnen steunen op een grote mate van nationale legitimiteit? In ieder geval is het argument dat het 'moet van Brussel' niet toereikend om (nationale) commitment te organiseren om de nieuwe generatie beleidsproblemen het hoofd te bieden.

De richting die paragraaf 5.4 aangeeft, is de volgende. Centraal staat het onderscheid tussen inputlegitimatie - legitimatie op basis van de kwaliteit van de (democratische) wijze van beleidsvorming - en outputlegitimatie, waarbij de kwaliteit van de uitkomst van beleid de legitimatie verschaft. Omdat de natiestaat voorlopig de enige instantie blijft die kan zorgdragen voor democratische inputlegitimatie (Scharpf 2002), doet de EU wiens beleidsvorming hoofdzakelijke steunt op outputlegitimatie, er goed aan arrangementen te zoeken die nationale institutionele voorzieningen voor inputlegitimiteit optimaal benutten. Die lijn geeft de hoogste kans om ook ten aanzien van de wicked milieuproblemen voortgang te kunnen blijven maken.

Op mondiaal niveau wordt het belang van samenwerking op basis van een gezamenlijke noemer van kleine(re) groepen van landen benadrukt als richting om te komen tot een operationeel internationaal milieubeleid dat declaratoire aspiraties overstijgt en invult (Hazeu en Schoonenboom 2002).

In paragraaf 5.5 wordt een aantal conclusies geformuleerd.

\subsection{DE ROL VAN KENNIS EN ONZEKERHEID}

Een essentieel aspect van de milieuproblemen van de toekomst zijn onzekerheden en risico's, die betrekking hebben op de oorzaak en aard van de problemen, op de mogelijke gevolgen ervan, en op de effecten van diverse mogelijk te nemen maatregelen. Er is sprake van onzekerheid wanneer de kans op het optreden van een bepaald probleem en de daarmee gepaard gaande gevolgen niet bekend zijn. Bij risico's wordt die kans wel bekend verondersteld. Ten behoeve van dit rapport 
zijn verkennende studies uitgevoerd rond het thema 'Perspectieven op milieurisico's' (Wissink en Bouma 2002) vanuit achtereenvolgens het perspectief van de financiële economie en kansrekening (door Lucas), het perspectief van de wetenschapsfilosofie/-sociologie (door Rip en Smit) en het perspectief van milieuaansprakelijkheidsrecht (door Van Dunné).

De risicoanalyse en het voorzorgsbeginsel zijn twee manieren om met milieuproblemen om te gaan die door onzekerheid worden gekenmerkt. Ze treden in werking wanneer milieuproblemen in zekere zin tot uiting zijn gekomen en zowel politiek als wetenschappelijk en maatschappelijk zijn geagendeerd. Er bestaat echter een belangrijk verschil tussen beide. Milieuproblemen bieden zich zelden in een vorm aan dat er onmiddellijk een van beide handelingsperspectieven op kan worden toegepast. De vaststelling dat er onvoldoende kennis aanwezig is en dat er onzekerheden zijn, is in deze gevallen niet het beginpunt, maar het eindpunt van intensief onderzoek. Een risicoanalyse valt echter nog binnen het domein van het handelen met behulp van wetenschappelijke kennis; er kunnen dan immers objectieve of subjectieve kansen worden gehanteerd. Als er onvoldoende kennis is over kansen is er sprake van fundamentele onzekerheid. Als er in zo'n situatie een beroep wordt gedaan op het voorzorgsbeginsel, is er sprake van een politiek-normatief besluit, omdat er bij gebrek aan voldoende kennis toch een politieke wil wordt uitgesproken. Het inhoudelijke normatieve element betreft met name een verhoogde risicoaversie (zie ook WRR 2003a: 151 e.v.).

Subparagraaf 5.2.1 gaat in op het belang van kennis bij het tot een oplossing (proberen te) brengen van milieuproblemen. Subparagraaf 5.2 .2 bespreekt de vraag hoe om te gaan met verschillende vormen van onzekerheid in relatie tot de nieuwe generatie milieuproblemen. In subparagraaf 5.2.3 komen de risicoanalyse en het voorzorgsbeginsel aan de orde, alsmede de relatie tussen die twee benaderingen. Subparagraaf 5.2.4 gaat vervolgens in op de rol van kennis en (on)zekerheid ten opzichte van de politieke besluitvorming. Subparagraaf 5.2.5 onderzoekt de arrangementen voor vermaatschappelijking van kennis.

\subsubsection{DE ROL VAN KENNIS VOOR DE NIEUWE MILIEUPROBLEMEN}

De effecten van de milieuproblemen van de toekomst zijn niet direct waarneembaar en dat maakt de signalering ervan in een vroeg stadium bijzonder moeilijk. Hier speelt wetenschappelijk onderzoek dan ook een cruciale rol. Dit geldt bijvoorbeeld voor de klimaatverandering (zie subpar. 4.4.2 en tekstbox 5.1). Het betreft de effecten op langere termijn die met een grote onzekerheid zijn omgeven en die bovendien politiek sterk omstreden zijn, omdat het sterk terugdringen van de uitstoot van broeikasgassen gepaard gaat met grote economische gevolgen. Dat maakt het daarop gerichte wetenschappelijke onderzoek ook controversieel.

Daar komt bij dat de wetenschap soms ook signalen afgeeft die achteraf niet blijken te kloppen en waarbij de mate van onzekerheid door wetenschappers zelf 
onvoldoende wordt benadrukt. De voorspellingen van de Club van Rome uit 1972 bijvoorbeeld bleken achteraf veel te pessimistisch omdat de maatschappelijke effecten van innovatieprocessen onvoldoende waren meegewogen. Een ander voorbeeld zijn geologische studies van het einde van de jaren zeventig waarin met grote stelligheid werd aangekondigd dat er waarschijnlijk een nieuwe ijstijd voor de deur zou staan. Inmiddels is dit, zoals bekend, drastisch omgebogen naar temperatuurstijgingen die vrij algemeen (maar zeker niet onbetwist!) worden toegeschreven aan het broeikaseffect.

Signalering en agendering van milieuproblemen hangen niet alleen af van de resultaten van wetenschappelijk onderzoek of van reacties van burgers op direct waarneembare effecten van milieuproblemen, maar worden ook beïnvloed door de wijze waarop bepaalde thema's worden gepresenteerd door actiegroepen en niet-gouvernementele organisaties (NGO's). Overigens bedienen deze groepen en organisaties zich veelal eveneens van wetenschappelijke kennis; de wetenschap is lange tijd de natuurlijke partner van de milieubeweging geweest om beargumenteerd op te kunnen treden tegen (in hun ogen) falende overheden en de industrie (zie tekstbox 5.1).

Historische meetreeksen van oplopende $\mathrm{CO}_{2}$-gehalten en temperaturen zijn de directe aanleiding geweest om een verband te veronderstellen tussen broeikasgassen en klimaatverandering. Verkennende simulatiemodellen zijn vervolgens gebruikt om te voorspellen wat het effect zou kunnen zijn van verschillende mogelijke handelingsscenario's, variërend van niets doen tot drastische ingrepen. Zoals is beschreven in subparagraaf 4.4.2 heeft dit aanleiding gegeven tot veel discussie, die tot op de dag van vandaag doorgaat. Niettemin zijn de resultaten van de analyses zodanig overtuigend gebleken, dat het probleem van de klimaatverandering als maatschappelijk probleem is erkend. Het heeft inmiddels een vaste, niet meer weg te denken, plaats op de internationale politieke agenda verkregen. Onderzoekers hebben deze analyse niet in splendid isolation uitgevoerd, maar de interactieprocessen hebben wel een speciaal karakter gehad. In eerste instantie waren er vooral contacten tussen onderzoekers onderling. Later ontstond er ook interactie met het bedrijfsleven en met verschillende NGO's. Zo werd de grote doorbraak pas bereikt toen Shell en bp het gesloten front van de olie-industrie doorbraken en de klimaatverandering als probleem erkenden. Deze stap kwam vooral tot stand op basis van de kwaliteit van de onderliggende wetenschappelijke analyses.

\subsubsection{ONZEKERHEID IN SOORTEN EN MATEN}

Als relatief jong beleidsgebied werd en wordt het milieubeleid op tal van onderdelen gekenmerkt door onzekerheid en gebrek aan kennis. Milliken (1987) maakte een onderscheid tussen onzekerheid ten aanzien van state, effect en response. Er kan onzekerheid bestaan over de aard van het milieuprobleem en de oorzaken ervan (state), over de gevolgen (effect), en over de maatregelen die genomen zouden kunnen worden om het probleem weg te nemen dan wel de nadelige effecten te mitigeren (response). De kennisonzekerheid zelf kan een zeer verschil- 
lende status hebben. Van Asselt (2000: 87-88) onderscheidt zeven categorieën, waarvan zij de eerste twee à drie rubriceert als onbetrouwbaarheid, en de laatste vier à vijf als structurele onzekerheid:

1 onnauwkeurigheid: 'ruwweg weten we het';

2 gebrek aan observaties en metingen: 'we zouden het kunnen weten';

3 praktische onmeetbaarheid: 'we weten wat we niet weten';

4 conflicterende evidentie: 'we weten niet wat we weten';

5 reduceerbare onwetendheid: 'we weten niet wat we nog niet weten';

6 onbepaaldheid: 'we zullen het nooit weten';

7 niet-reduceerbare onwetendheid: 'we kunnen het niet weten'.

De onzekerheid kan van voorlopige aard zijn: er doet zich een negatief geduid of ervaren verschijnsel voor, het problematische karakter zet vervolgens een proces van (nadere) kennisverwerving in gang, dat na verloop van tijd in positieve kennis resulteert (BSE bijvoorbeeld). Het is evenwel ook denkbaar dat de complexiteit van het probleem dermate groot is dat deze kennis niet kan worden verkregen. Dan kan sprake zijn van onkenbaarheid: de onwetendheid is structureel of zelfs principieel van aard (onbepaaldheid of niet-reduceerbare onzekerheid).

Deze gradaties van onzekerheid zijn niet alleen relevant in het geval van de milieuproblemen en hun mogelijke gevolgen zelf (state en effect), maar ook waar het gaat om de te nemen maatregelen (response). Bij het bepalen van deze maatregelen speelt niet alleen de invloed op het milieuprobleem een rol, maar eveneens de ontwikkeling van de maatschappelijke activiteit waaraan beperkingen moeten worden gesteld, en de toekomstige interactie tussen deze activiteit en het milieuprobleem.

\section{Het zoeken naar zekerheid}

Bij het bepalen van de aard van het milieuprobleem, de effecten ervan en de te hanteren oplossingsrichting speelt the quest for certainty (Dewey 1960) bij alle participanten in het proces van menings- en besluitvorming een belangrijke rol. Iedereen wil vanzelfsprekend de feiten aan zijn zijde hebben. De zes casussen tonen grote verschillen in de mogelijkheid om meer zekerheid te krijgen:

- Bij Rijnmond zijn objectieve observaties aanvankelijk vrijwel afwezig; de klachtenlijn en het meetsysteem maken het toetsen van de ervaren hinder vervolgens mogelijk, waardoor veel problemen kunnen worden opgelost.

- Ook bij Schiphol gaat het voor een deel van de milieuproblemen om onzekerheid die via een meetsysteem kan worden gereduceerd. Maar het blijkt een zeer complexe opgave te zijn om een observatiesysteem te vinden dat de hinder niet alleen in objectieve zin, maar ook op een voor alle belanghebbenden aanvaardbare wijze benadert. Zeker waar het gaat om de normvinding die zou moeten gelden bij een uitbreiding van Schiphol komen vraagstukken in het geding die eerder als structureel onzeker moeten worden gekwalificeerd. Het gaat dan niet meer louter om een milieukundig vraagstuk, maar eerder om een afweging van milieukundige en sociaal-economische en technologische vraagstukken, zoals 
de toekomstige vraag naar luchtvaartdiensten, de werkgelegenheid die de luchthaven bij verschillende modaliteiten aantrekt, en dergelijke.

- Rond de Nitraatrichtlijn speelt de vraag welke indicator het milieuprobleem het beste benadert en zijn er onzekerheden over de interactie van bepaalde voorgeschreven gedragsnormen en de milieukundige gevolgen ervan. Een gebrek aan metingen ten aanzien van de uiteindelijke normen en conflicterende evidentie ten aanzien van de daaraan voorafgaande normeringen lijken hierbij een rol te spelen. Gaandeweg is hierover echter meer zekerheid ontstaan.

- De Vogelrichtlijn kent een stevige wetenschappelijke basis: de ontwikkeling van de vogelstand in Europa is redelijk goed in kaart gebracht, evenals het treken fourageergedrag.

- De klimaatontwikkeling en de oorzaken en gevolgen ervan horen eerder thuis in de categorie 'structurele onzekerheid'. Ondanks alle voortgang op deelgebieden blijft met name het antropogene aandeel hierin onderwerp van onzekerheid, waarbij het de vraag is - en ook onderwerp van controverse - welke van de drie laatstgenoemde categorieën van Van Asselt hier opgeld doet. Ook bestaat er onzekerheid over de gedragseffecten van mogelijke of overeengekomen maatregelen, zoals van verhandelbare vervuilingsrechten.

- De aard van de onzekerheden die zijn verbonden aan chloormicro's wordt eveneens betwist: gaat het hier om een praktisch probleem (te kostbaar om alle effecten van alle micro's te kunnen kennen) of om een principieel probleem van onkenbaarheid? Ook hier gaat het niet alleen om milieukundige onzekerheden en risico's; mogelijkheden voor omschakeling naar alternatieven voor chloor (response) vormt eveneens een bron van grote onzekerheden van bedrijfseconomische aard.

\subsubsection{RISICOANALYSE EN VOORZORGSBEGINSEL}

Bij de aanpak van de (nieuwe) milieuproblemen spelen de risicoanalyse en het voorzorgsbeginsel een belangrijke rol.

\section{Risicoanalyse}

In de vorige subparagraaf is de studie van Van Asselt (2000) al aangehaald, waarin onderscheid wordt gemaakt tussen twee hoofdcategorieën van onzekerheid. In de eerste groep kan de onzekerheid door meting of monitoring worden verminderd of opgeheven, omdat er sprake is van goed begrepen systemen of processen. Onzekerheden kunnen in dat geval ook stochastisch worden weergegeven in termen van 'kansen van voorkomen' met bijbehorende effecten, waardoor ze als input kunnen fungeren voor risicoanalyses (zie ook Wissink en Bouma 2002). Die eerste categorie is van toepassing op een aantal moderne milieuproblemen. Zo heeft het intensief meten en monitoren van het klimaatsysteem geleid tot het sterk verminderen van de onzekerheid op onderdelen, ook al is het (nog) niet mogelijk om het gehele klimaatsysteem, met al zijn terugkoppelingen tussen deelsystemen, in zijn totaliteit analytisch te beschrijven. In dit verband komt het voorzorgsbeginsel aan de orde. 
Dit laatste aspect behoort tot de tweede groep, waar de onzekerheden (nog) zo groot zijn dat een inschatting van de kans van voorkomen van effecten met de bijbehorende gevolgen niet mogelijk is vanwege onbepaaldheid en onwetendheid. Hoogstens kunnen ruwe schattingen worden gemaakt van optredende fenomenen, maar in veel gevallen zal slechts sprake kunnen zijn van normatieve of ethische uitgangspunten bij het benaderen van de problematiek, zoals Van den Bergh (2002) illustreert voor het klimaatbeleid.

\section{Voorzorgsbeginsel}

De meest gezaghebbende definitie van het voorzorgsbeginsel kan worden ontleend aan de Verklaring van Rio (1992):

"In order to protect the environment, the precautionary approach shall be widely applied by the States according to their capabilities. Where there are threats of serious or irreversible damage, lack of full scientific certainty shall not be used as a reason for postponing cost-effective measures to prevent environmental degradation (Principle 15)."

Bij de interpretatie van dit complexe beginsel, waarbij sprake is van een dubbele ontkenning, is het nuttig twee verschillende uitgangspunten te onderscheiden, namelijk (1) het optreden van een actueel milieuprobleem, en (2) de verwachting dat een probleem zal optreden. In het eerste geval worden er schadelijke milieuprocessen waargenomen en is de vraag of er corrigerende maatregelen dienen te worden genomen. In het tweede geval worden er menselijke activiteiten voorgesteld die ongunstige milieueffecten tot gevolg zouden kunnen hebben en is de vraag of deze activiteiten kunnen worden toegestaan. Dit onderscheid in twee categorieën wordt in veel discussies over het voorzorgsbeginsel niet gemaakt, hetgeen makkelijk tot verwarring kan leiden.

Een deel van de onzekerheden die samenhangen met de nieuwe generatie milieuproblemen kan door wetenschappelijk onderzoek worden weggenomen, maar er zal nooit sprake kunnen zijn van absolute zekerheid over oorzaken en gevolgen. Als absolute zekerheid het algemene en absolute uitgangspunt van handelen zou zijn, zou dat resulteren in totale inertie en gebrek aan initiatief. Dit zou een onwenselijke, want uitzichtloze situatie scheppen. Het voorzorgsbeginsel doorbreekt deze patstelling bij het eerste uitgangspunt en erkent dat actie kan zijn geboden, ook al bestaat er geen absolute zekerheid over oorzaken en gevolgen. Geredeneerd vanuit het tweede uitgangspunt kan het voorzorgsbeginsel echter juist wel tot gebrek aan actie leiden ('bij twijfel niet doen'). Dit laatste wordt door critici dan ook vaak als bezwaar aangevoerd (Hanekamp 2002; Pieterman en Hanekamp 2002). Twee milieuproblemen kunnen als voorbeeld worden aangehaald ter nadere illustratie van het hiervoor aangehaalde onderscheid: het ozonprobleem en de Waddenzee (zie de tekstboxen 5.2 en 5.3). 


\section{Tekstbox 5.2 De ozonlaag}

Rond 1980 constateerden wetenschappers op basis van satellietmetingen dat de ozonlaag rond de aarde werd aangetast. Er ontstonden periodiek grote gaten, die schadelijk waren voor het leven op aarde omdat de ozonlaag in dit geval het ultraviolette licht van de zon niet meer kon uitfilteren voordat het de aarde bereikte. Er waren aanwijzingen dat door de mens gefabriceerde chloorfluorcarbons (CFC's), die onder meer gebruikt werden in koelkasten, dit effect veroorzaakten. Een concreet bewijs kon echter niet worden geleverd. Niettemin werd, in de geest van het voorzorgsprincipe, toch actie ondernomen. De Verenigde Staten en het Verenigd Koninkrijk namen het initiatief voor het Montreal-Protocol uit 1987, dat voorzag in de beëindiging van de productie van CFC's. In eerste instantie was de industrie niet bereid mee te werken, maar Du Pont en ICI doorbraken het gesloten industriële front. Dit leidde al snel tot de productie van een vervangende, niet-schadelijke vloeistof die inmiddels overal wordt gebruikt. Er zijn nu aanwijzingen dat de ozonlaag zich herstelt.

Onzekerheid over de oorzaken van een gesignaleerd probleem mag niet leiden tot inertie als het risico hoog wordt ingeschat op basis van de kans van voorkomen en de te verwachten effecten. Nieuw onderzoek heeft aangetoond dat de dreiging van het verdwijnen van de ozonlaag veel ernstiger was dan men zich in de jaren tachtig realiseerde. De inschatting van het risico en de toepassing van het voorzorgsprincipe was dus gerechtvaardigd.

Het ozonprobleem is een voorbeeld van de eerste categorie. Er was geen sluitend wetenschappelijk bewijs, maar er waren wel aanwijzingen dat het dunner worden van de ozonlaag als gevolg van menselijke activiteiten grote gevolgen zou kunnen hebben voor het leven op aarde. Daarom is actie ondernomen. Twee elementen uit de Rio-definitie van het voorzorgsbeginsel vragen hierbij om aandacht: er was aantoonbaar sprake van "threats of serious and irreversible damage”, terwijl ook spoedig bleek dat kosteneffectieve maatregelen mogelijk waren, door het beschikbaar zijn van niet te dure vervangende chemicaliën die voor de industrie aantrekkelijk waren. Het afschaffen van CFC's is daarom relatief snel en probleemloos verlopen.

De Waddenzee is een voorbeeld van de tweede categorie. Een sluitend wetenschappelijk bewijs dat boren naar gas onder het wad geen ongunstige ecologische gevolgen heeft, kan niet worden gegeven. Hoe zit het nu met de "threats of serious or irreversible damage" en de "cost effective measures to prevent environmental degradation"? De eerste vraag is impliciet in positieve zin beantwoord, want er wordt niet geboord. Maar deze beslissing is niet gebaseerd op een sluitende aardwetenschappelijke of ecologische analyse. Immers, de onzekerheden zijn te groot, en er kan alleen worden geconcludeerd dat het optreden van ecologische schade niet is uit te sluiten. De tweede vraag is in feite nooit gesteld omdat de risico's van boren in dit gebied als te hoog zijn beoordeeld, waardoor een discussie over gevolgen en mogelijke manieren waarop die gevolgen zouden kunnen worden beperkt, is geblokkeerd. Toch zou het wenselijk zijn dat, in dit geval, wordt gediscussieerd over wat het niet-boren betekent voor onze energievoorziening. Welke alternatieven zijn er en wat zou aanwending van deze alter- 
natieven voor het milieu kunnen betekenen? Hoe is onze reactie bijvoorbeeld als we als gevolg van het niet-boren in de Waddenzee energie zouden moeten importeren die door atoomenergie of door het stoken van bruinkolen is verkregen?

\section{Tekstbox 5.3 De Waddenzee}

De Waddenzee is een uniek, door UNESCO erkend natuurgebied. In de diepe ondergrond is gas aangetroffen en oliemaatschappijen hebben plannen gemaakt om dit gas via boringen te winnen. Om schade aan het kwetsbare ecosysteem te voorkomen, is voorgesteld die boringen vanaf het land in schuine richting uit te voeren. Daarmee wordt plaatsing van boortorens in het wad voorkomen. Niettemin is al eerder op het vasteland gebleken dat gasonttrekking kan leiden tot maaivelddaling boven de plek van onttrekking, meestal in onvoorspelbare schokken die leiden tot onregelmatige en ook onvoorspelbare bodemdalingen van centimeters tot decimeters. Waar dat gebeurt en in welke mate is niet te voorspellen. Zeker is wel dat het een significant effect zou kunnen hebben op het wadmilieu, waar verschillen van enkele centimeters in hoogte ten opzichte van het zeeniveau al ecologische consequenties hebben. Aan onderzoekers is gevraagd uit te rekenen hoe groot het effect van boringen op het wadmilieu zou kunnen zijn en of deze effecten als schadelijk zouden kunnen worden aangemerkt. Het bleek vervolgens natuurwetenschappelijk niet mogelijk om dergelijke effecten nauwkeurig te berekenen, want het gaat om centimeters hoogteverschil. Door stroming, sedimentatie en erosie verandert het oppervlak van het wad voortdurend, ook zonder dat er wordt geboord. Het referentieniveau is dus dynamisch en nauwelijks te definiëren. Bovendien stijgt het zeeniveau ook nog langzaam en daalt het land, beide in absolute zin. Het vaststellen van het specifieke effect van boringen op de oppervlaktedynamiek van het wad is derhalve een onmogelijke taak gezien de kleine verschillen in de orde van centimeters hoogte, die voor plant en dier belangrijk zijn. Het is dus wetenschappelijk onmogelijk vast te stellen wat het effect zal zijn van boringen op de dynamiek van het wad. Hoogstens kan worden verondersteld dat een mogelijke bodemdaling door sedimentatie kan worden gecompenseerd, maar dit zou wel een verstoring van de natuurlijke sedimentatiepatronen betekenen. De ernst daarvan blijft moeilijk te voorspellen. Dit geldt onveranderlijk als alleen aan de rand zou worden geboord en wanneer alleen maar kleine gasbellen zouden worden aangeprikt. (Deze laatste scenario's zijn door de industrie als laatste variant aangeboden.) Ook in dit geval zal de wetenschap nooit het verlossende woord kunnen spreken en zal de besluitvorming vanuit een politieke afweging moeten worden gerealiseerd. Het is belangrijk dat de wetenschap dit duidelijk signaleert en daarmee zijn eigen grenzen trekt en niet suggereert ook een andere, meer beslissende rol te kunnen of willen vervullen.

Bij de klimaatproblematiek zijn er veel meer mogelijkheden dan bij de gasboringscasus om de ontwikkelingen met metingen en modellen te illustreren. Hoewel ook hier sprake blijft van onzekerheid en twijfel, worden de risico's van het niets doen als dermate groot ervaren, dat in de geest van het voorzorgsprincipe tot actie kan worden besloten. De conclusie is daarmee dat onzekerheid alléén een slechte raadgever is; een systematische risicoanalyse - waar mogelijk kan concrete aanknopingspunten opleveren, ook al resulteert zo'n analyse niet in een klip-en-klaar en onomstreden besluit. 


\section{Risicoanalyse versus voorzorgsbeginsel}

Bij de analyse van de chloorcasus in subparagraaf 4.4.3 (een modern milieuprobleem) is de tegenstelling tussen risicoanalyse en voorzorgsbeginsel scherp naar voren gekomen. De industrie ging uit van een benadering waarbij een risicoanalyse werd gepropageerd, terwijl de milieubeweging pleitte voor toepassing van het voorzorgsbeginsel omdat naar haar mening de kennis over het optreden van effecten en de gevolgen daarvan volstrekt onvoldoende was. Bij nog niet beheersbare milieuproblemen is een cruciale vraag in hoeverre, gezien de in het spel zijnde onzekerheden, traditionele risicoanalyses verantwoord zijn. Tegelijkertijd dient daarbij de vraag te worden gesteld of bij toepassing van het voorzorgsbeginsel voldoende rekening wordt gehouden met alle implicaties en alternatieve mogelijkheden.

Risicoanalyse noopt tot een afweging van risico's. Die (gepercipieerde) risico's moeten worden afgewogen in de politieke besluitvorming. Daarbij speelt ook de gewenste mate van risicomijding een rol. Risicoanalyse kan uitwijzen dat ten opzichte van belangrijke relaties en effecten, en gegeven de gewenste mate van risicomijding, de kennis ontoereikend is om (voldoende) zekerheid te verschaffen. In die gevallen kan de afweging tussen het bekende en het onbekende nopen tot voorzorg. Daar, aan de 'rand van de kennis', kan de politiek voor voorzichtig-

heid opteren. Het voorzorgsbeginsel is derhalve eerder een normatief concept dat wordt ingegeven door risicomijding bij grote onzekerheid, dan een wetenschappelijke benadering. Zo gezien, is het de vraag hoe vruchtbaar het is om risicoanalyse en voorzorgsbeginsel tegenover elkaar te plaatsen bij de benadering van (de nieuwe) milieuproblemen. Het voorzorgsbeginsel kan immers worden gezien als een onderdeel van de risicoanalyse. Het is een punt aan het einde van het spectrum, waar een grote onzekerheid gepaard gaat met een hoge riscoaversie.

\subsubsection{DE ORGANISATIE VAN DE KENNISINBRENG IN HET BELEID}

\section{Voortgaande kennisopbouw}

Om de nieuwe milieuproblemen het hoofd te kunnen bieden, zal de inbreng van wetenschappelijke kennis alleen maar belangrijker worden. Juist ook voor problemen waarover veel (op zichzelf reduceerbare) onzekerheid bestaat en zelfs voor die categorieën van problemen die onbepaald zijn, is wetenschappelijke kennisinbreng onontbeerlijk, soms ook om in kaart te brengen wat we niet weten. Deze probabilistische benadering van onzekerheid is de kern van de risicoanalyse. Wat de rol van kennis betreft, en de hiervoor beschreven quest for certainty van de betrokken actoren, is de conclusie dat 'de wetenschap' nooit een absolute scherprechter kan zijn. Het opbouwen en het verspreiden van hoogwaardige milieukennis (over klimaat, biotechnologie enz., maar ook disciplinaire bètakennis) zijn zeer belangrijk, maar de factor kennis treedt niet in de plaats van de politieke keuzes en afwegingsprocessen die moeten worden gemaakt. Al is het alleen maar dat er als regel vanuit de wetenschap geen volledige zekerheid kan worden geboden over de complexe causaliteiten bij de 'nieuwe' milieuproblemen; soms bestaat er zelfs tegenstrijdigheid in wetenschappelijke opvattingen. 
Wel kunnen een gezamenlijk gedeelde kennisbasis en het vertrouwen dat er op verantwoorde wijze met die kennis wordt omgegaan, de legitimiteit van maatregelen in de samenleving bevorderen. De inbedding van kennis in het beleidsproces verdient daarom grote aandacht. (Verdere) kennisgaring moet ook niet worden stopgezet in gevallen waar vanuit het voorzorgsbeginsel is gekozen voor een 'niet doen'. Het belang van onafhankelijke kennisgaring, het organiseren van goede, onafhankelijke kennisinstituten, en van de doorsijpeling van die kennis, zijn des te meer van belang om tot beleidsvorming en beleidslegitimering te komen. De rol van het IPCC in de klimaatcasus is daar een goed voorbeeld van: het betreft een gezaghebbend internationaal netwerk van toponderzoekers dat de wetenschappelijke agenda vaststelt en dat ook steeds meer (gestructureerde) interactie heeft met beleidsorganen op verschillende niveaus. De wetenschap internationaliseert op deze manier op een wijze die anders is dan het entameren van gemeenschappelijke internationale onderzoeksprojecten zoals dat al veel langer gebeurt. De wetenschap is, in het algemeen, naar haar aard internationaal georiënteerd, maar de organisatie van de wetenschap heeft toch tal van nationale gebondenheden (fysiek, taal, financiering enz.). De internationale samenwerking tussen milieuonderzoeksinstituten (zoals het RIVM) kan op een hoger plan worden gebracht. De nadruk op verdere internationalisering en europeanisering van het milieubeleid zou hiertoe ook een impuls moeten geven. Het kan ook ‘leerprocessen’ tussen verschillende (EU-)landen helpen versterken.

\section{Kennisinbreng naar beleidsfuncties}

Bij het uitstippelen van het beleid is het van belang dat de gekozen doelen en middelen geen statisch, maar een dynamisch karakter hebben. Het vaststellen van doelen en middelen is met andere woorden een iteratief proces, dat mede onder invloed staat van het beschikbaar komen van nieuwe kennis en informatie, maar ook van het wisselend belang dat wordt gehecht aan milieu- en andere maatschappelijke waarden. Dat maakt beleid maken tot een moeizaam en ingewikkeld proces waarin vele actoren en factoren een rol spelen. In de praktijk bestaat dat proces dan ook niet uit netjes op elkaar volgende fasen. Analytisch kan er natuurlijk wel onderscheid worden gemaakt tussen het agenderen van problemen, het verkennen van oplossingsmogelijkheden, het nemen van besluiten, en de implementatie daarvan. De manier waarop de kennisinbreng daarbij wordt georganiseerd, is verschillend, al naar gelang wat aan de orde is. Hoofdstuk 4 heeft laten zien dat bij zowel de Vogelrichtlijn als de nitraatcasus de probleemsignalering en -agendering direct zijn gevolgd door besluitvorming en implementatie. Een verkenning van de verschillende oplossingsmogelijkheden in samenspraak met de stakeholders is niet ondernomen. Dat wreekte zich bij de implementatie van de genomen maatregelen. De claim hier is, met andere woorden, dat een combinatie van kennis én interactie een betere beleidsvorming ten goede kan komen. 


\subsubsection{ARRANGEMENTEN VOOR VERMAATSCHAPPELIJKING VAN KENNIS}

Het domein van kennisgaring ter vermindering of verduidelijking van onzekerheden staat niet los van dat van waarden. Weliswaar is er een arbeidsdeling tussen de werelden van het kennen (de wetenschap) en het handelen (politiek en beleid), maar evenzeer als er in het sollen veel sein zit verscholen, is ook kennis standortgebunden. Feiten krijgen pas betekenis in een beoordelingskader, en hierbij spelen waarden en belangen een belangrijke rol. Wat bijvoorbeeld in Nederland wordt gedefinieerd als 'natuur' is moeilijk los te zien van de culturele activiteiten in het verleden; huidige opvattingen over natuur zijn daarvan - bij alle verscheidenheid - een afgeleide. Dergelijke opvattingen zijn dan ook bepalend voor de tellingen van flora- en faunasoorten en de waardering van de resultaten. Zeker als kennis een belangrijke basis van beleid vormt, zoals bij milieubeleid, en dit beleid zozeer raakt aan belangen en aangehangen waarden, is de status van voor de beleidsontwikkeling gegenereerde kennis zelf een belangrijk onderwerp van discussie.

Dit blijkt dan ook het geval geweest te zijn in alle zes geanalyseerde casussen in hoofdstuk 4. In situaties waar de percepties van het probleem sterk uiteenlopen, doen de verschillende partijen vaak een beroep op expertise die hun standpunt ondersteunt. Men probeert derhalve wetenschappelijke legitimatie te verwerven voor het doen aanvaarden van de eigen probleemdefinitie, resulterend in contesstatie over en weer. De overheid probeert in deze situatie nogal eens om via 'veronafhankelijking' van de kennisvergaring de betwiste elementen te identificeren en te verduidelijken. Door deze precisering en objectivering streeft men ernaar het maatschappelijke conflict te ontdoen van de alles-of-niets-waardegeladenheid, om zo toch tot aanvaardbare besluitvorming te komen (zie bijv. de huidige - moeizame - pogingen om de geluidsproblematiek van Schiphol deels bij een onafhankelijke commissie neer te leggen).

Terwijl aanvankelijk de preferenties van de voornaamste stakeholders de discussie domineren, kunnen feitelijke informatie, het onderscheiden tussen zekerheden en onzekerheden, het inbrengen van een breder spectrum aan overwegingen, ook tot nuancering van de initiële posities leiden. In Rijnmond heeft het gaandeweg verfijnde meetsysteem deze functie van objectivering vervuld. Bij Schiphol zijn verschillende kosten-batenanalyses uitgevoerd, waarbij is gepoogd duidelijkheid te verschaffen over alle door belangengroepen ingebrachte argumenten. Ten aanzien van chloor is, respectievelijk wordt, uiteindelijk via de Stuurgroep Chloor en Alternatieven en het ovoc-onderzoeksprogramma gepoogd helderheid te krijgen over de grote, uit zeer verschillende interpretatiekaders voortvloeiende twistpunten. Het IPCC is uitdrukkelijk bedoeld om de stand van de kennisontwikkeling over het klimaat te evalueren en recht te doen aan alternatieve verklaringen, ook aan die welke door grote belanghebbenden zoals Shell naar voren zijn gebracht. De Vogelrichtlijn is uitzonderlijk, omdat de wetenschappelijke basis hiervan niet wordt betwist. Het is overigens niet denkbeeldig dat dit toch zal gaan gebeuren als de consequenties ervan ten volle duidelijk 
worden. Rond de Nitraatrichtlijn, waarvan die basis wel controversieel is, wordt pas de laatste tijd doelgericht onderzoek ingezet dat is gericht op de argumenten van de boeren.

Deze veronafhankelijking van de kennisbasis voor de besluitvorming impliceert natuurlijk niet dat de resulterende kennis en informatie volledig waardevrij kunnen zijn. Het betreft - zoals is gesteld in hoofdstuk 3-een poging om valid and reliable knowledge om te vormen tot shared knowledge (March 1994: 240) van de groeperingen die een belang hebben bij de besluitvorming. Het gaat derhalve om het vinden van manieren om wetenschappelijke kennis - dat wil zeggen kennis en informatie die voldoet aan wetenschappelijke kwaliteitsmaatstaven toepasbaar en aanvaardbaar te maken binnen de termen die worden gehanteerd door betrokken actoren (Latour 1999). Participatie van de betrokken partijen bij het tot stand brengen en uitvoeren van de onderzoeksagenda, en bij de evaluatie van de resultaten, is dan ook belangrijk. Uit de casussen blijkt dat hiervoor allerlei vormen denkbaar zijn. In de chloorcasus is een begeleidingscommissie ingesteld om de relevante actoren (onderzoekers, bedrijfsleven, milieubeweging) bij het proces te betrekken. In het geval van Schiphol heeft een onafhankelijke commissies ervoor gewaakt dat er rekening is gehouden met alle belangen in de verschillende door onderzoeksinstellingen uitgevoerde kosten-batenanalyses. In Rijnmond is het meetnet direct gekoppeld aan de klachtenlijn en zijn de resultaten frequent doorgegeven aan de bevolking.

Deze arrangementen van vermaatschappelijking van kennis, waarbij kennisproductie en maatschappelijke participatie met elkaar verstrengeld raken, behoeven geen afbreuk te doen aan de onafhankelijkheid van de gegenereerde kennis. Door het inbouwen van checks and balances kan eenzijdigheid worden voorkomen. Dit bevordert de maatschappelijke aanvaardbaarheid van probleemdefinitie en de haalbaarheid en effectiviteit van de oplossingsrichting - voorzover die ex ante beoordeelbaar zijn. Maar het blijft natuurlijk onvermijdelijk dat de gegenereerde kennis veelal een grote variatie van (on)zekerheid zal vertonen, gebonden is aan betwistbare veronderstellingen, noodzaakt tot afwegingen tussen 'appels en peren', en een hoge mate van complexiteit kent. Welvaartsanalyse, inclusief waarderings- en besliskundige technieken, kan de keuzes die in het geding zijn zo goed mogelijk verhelderen, maar uiteindelijk niet voorschrijven. Kennis leidt nu eenmaal niet linea recta naar besluitvorming. Deskundigen kunnen de meningsvorming voeden, maar besluiten moeten door relatieve 'leken' worden genomen. In dit opzicht is de door de Tweede Kamer gehanteerde werkwijze rond de klimaatverandering interessant (zie tekstbox 5.4). 


\section{Tekstbox 5.4 De Kamercommissie Klimaatverandering en het IPCC}

In 1995 stelde de Tweede Kamer de Tijdelijke Commissie Klimaatverandering in, met als opdracht zelfstandig onderzoek te verrichten naar aard en omvang van het probleem van de klimaatverandering, c.q. het versterkte broeikaseffect, en zonodig beleidsdoelstellingen te formuleren voor het aanpakken van het probleem. In de commissie waren alle grote politieke partijen vertegenwoordigd. Meer dan elke andere parlementaire commissie was zij aangewezen op de inzichten van onderzoekers, van klimaatdeskundigen tot economen. Alvorens hoorzittingen te houden, bestudeerde de commissie de IPCC-rapporten, maakte zij een selectie van de wetenschappelijke onderzoekers die zij wilde horen en raadpleegde zij vele deskundigen. Expliciete aandacht werd besteed aan de wijze waarop leken experts moesten bevragen. Aldus ontwikkelde de commissie gevoeligheid voor het onderscheid tussen feiten, schattingen met onzekerheidsmarges, oordelen over nog niet onderzochte grootheden en subjectieve waarderingen. De hoorzittingen kregen het karakter van een integrated assessment; rivaliserende theorieën kregen ruimschoots aandacht. De commissie verwierf zo een goed inzicht in de IPCC-werkwijze en de status van diens uitspraken. In het eindrapport werd een duidelijke cesuur aangebracht tussen het door onderzoekers ingebrachte materiaal en haar eigen politieke oordeelsvorming. Het eindoordeel luidde dat er gezien de beschikbare inzichten over aard en gevolgen van de klimaatverandering alle aanleiding was het zekere voor het onzekere te nemen, en derhalve beleid te voeren vanuit het voorzorgsbeginsel. Let wel, de toepassing van het voorzorgsbeginsel was dus een keuze die uit dit besluitvormingsproces voortkwam; het was geen dictum op voorhand of van hogerhand of van een hogere orde!

Normaal gesproken heeft nieuw beleid een belangrijke rechtvaardigingsgrond in een manifest probleem dat boven een kritische grens is uitgegroeid. Maar een meer scrupuleuze werkwijze verdient navolging bij complexe milieuvraagstukken die zich mogelijk kunnen aandienen, en waartoe het voorkomen of mitigeren nu toch al grote offers vraagt. Juist hier is het immers problematisch om tot een antwoord te komen op vragen van aanvaardbaarheid, haalbaarheid, en - zoals bij het beschreven voorbeeld - de rechtsgrond van te ontwikkelen beleid. Bij dit type problemen, waarvoor ook vraagstukken als biodiversiteit, biotechnologie en de toekomst van de luchthaven kandidaat zijn, is het van eminent belang dat de volksvertegenwoordiging haar eigen verantwoordelijkheid neemt, gezien de grote verwevenheid van private en publieke belangen.

Hiermee wordt overigens niet gesuggereerd dat het zorgvuldig verifiëren van de kennisbasis bij problemen die dichter bij huis liggen, van minder belang zou zijn. Het argument is eerder dat het, bij onzichtbare processen, die alleen wetenschappelijk benaderbaar zijn, is het buitengewoon lastig tot beleid te komen dat kan rekenen op een a priori maatschappelijke aanvaarding van te brengen offers. Bij manifeste problemen staan overheden juist bloot aan grote maatschappelijke druk om maatregelen te nemen die mogen rekenen op een hoge mate van aanvaardbaarheid, maar waarvan de kennisbasis twijfelachtig is. Dit kan worden verduidelijkt aan de hand van de voorbeelden in de tekstboxen 5.5 en 5.6. 


\section{Tekstbox 5.5 Ziekten en plagen in de biologische landbouw}

De afgelopen jaren zijn er veel problemen in de landbouw opgetreden, zoals BSE, MKZ en varkenspest. Die zijn breed in de media gerapporteerd en worden vaak gezien als gezondheidsbedreigende gevolgen van de moderne, grootschalige en industriële vorm van landbouw. Biologische landbouw, waarbij geen synthetische chemische productiemiddelen worden gebruikt en die kleinschalig is, komt in de beeldvorming naar voren als een gezond alternatief. Over de merites van deze vorm van landbouw is echter maar weinig bekend, ook als gevolg van verzet van de aanhangers tegen evaluerend onderzoek. In antwoord op de crises wordt door de minister van LNV gestreefd naar ten minste tien procent biologische landbouw en in Duitsland zelfs naar twintig procent. Op zichzelf is hier weinig op tegen als consumenten bereid zijn hogere prijzen te betalen voor organisch geteelde producten, die ze ook waarderen als een expressie van een alternatieve way of life. Vanuit wetenschappelijk perspectief is - gemeten aan dezelfde criteria - het biologische productiesysteem echter niet vanzelfsprekend beter dan het niet-biologische en kunnen ook moderne, niet-biologische landbouwsystemen aan hoge kwaliteitscriteria voldoen. Zo vragen ten aanzien van biologische systemen enkele punten de aandacht. Door het gebruik van organische voedingsstoffen is voor eenzelfde productie in de biologische landbouw ruim twee keer zoveel land nodig als in de niet-biologische. Verder betekent het niet met synthetische middelen kunnen bestrijden van schadelijke schimmels dat producten hiervan, zoals mycotoxinen, biologische producten kunnen verontreinigen. Zo zijn fumonisine en patuline in relatief hoge concentraties in biologische producten aangetroffen. Dit betekent niet dat biologische producten niet veilig kunnen zijn. Wanneer echter vanuit wetenschappelijke optiek de product- en milieukwaliteit van producten uit beide productiesystemen aan dezelfde criteria worden getoetst, komen biologische producten niet naar voren als per definitie het gezondere alternatief.

Bij de biologische landbouw is de schadelijkheid van mycotoxinen ontkend, omdat zij niet paste binnen het ideaalbeeld van biologische landbouw. De casus illustreert daarmee dat het beleid niet altijd de verleiding kan weerstaan mee te gaan met opvattingen die op het eerste gezicht evident lijken, maar die bij nader inzien berusten op gebrek aan kennis over de kenmerken van biologische landbouw en op romantische opvattingen over 'natuurlijke' producten. Dat de overheid belemmeringen voor nichemarkten wegneemt is één ding, maar ze zou ertegen moeten waken dat dit geschiedt op niet-onderbouwde gezondheidsclaims, zeker omdat zaken aangaande gezondheid bij uitstek snel tot verontrusting kunnen leiden. De wetenschap heeft de verantwoordelijkheid om de resultaten van objectieve metingen en de implicaties daarvan te melden. Of het beleid hier vervolgens rekening mee houdt, is een andere zaak. Er zijn duidelijk gescheiden verantwoordelijkheden. Wetenschappelijk onderzoek zou hier juist moeten kunnen worden ingezet om de consument tot een beter gefundeerd oordeel te kunnen laten komen.

De laatste casus van deze paragraaf illustreert dit punt nog eens, maar hier gaat het niet om een maatschappelijk 'goed liggend' voorbeeld, maar juist om een ontwikkeling die maatschappelijk zeer betwist wordt, te weten de ecologische gevolgen van de introductie van genetisch gemodificeerde maïs (Bt Maïs; tekstbox 5.6) waarbij veldwaarnemingen duidelijk werden geïnterpreteerd vanuit een bepaalde visie. 


\section{Tekstbox 5.6 Bt Maïs}

Er bestaat de zorg dat genetisch gemodificeerde voedselgewassen schade kunnen aanrichten aan het ecosysteem waarin het gewas wordt geteeld. Een voorbeeld is de zogenoemde Bt maïs. In deze maïs is een gen geïmplanteerd die het Bt toxine produceert. Dit gen is verkregen uit de bacterie Bacillus thuringiensis. Genoemde toxines komen in de natuur voor, worden op natuurlijke wijze afgebroken en zijn onschadelijk voor de mens. Biologische boeren gebruiken ze in de praktijk met succes als spray voor het bestrijden van schadelijke insecten. Zelfs Rachel Carson, de schrijfster van Silent spring, heeft het gebruik van deze toxines als natuurlijk product voor de bestrijding van insectenplagen aanbevolen. De corn borer is een zeer schadelijk insect die de productie van de maïsplant sterk kan reduceren. Omdat het diertje binnenin de maïsplant zit, is het moeilijk te bestrijden en zijn daarvoor grote hoeveelheden biociden nodig, die als neveneffect de bodem en het water kunnen verontreinigen. Door nu het Bt gen in te bouwen in de maïsplant, wordt het toxine door de plant zelf geproduceerd, waardoor de corn borers worden gedood. Dit blijkt in de Verenigde Staten uitstekend te werken en heeft als neveneffect dat het gebruik van biociden sterk is teruggelopen.

Maar wat is het effect van deze genetisch gemodificeerde maïs in het veld? Worden de pollen van de maïs door de wind meegevoerd naar plekken waar ze wellicht schade kunnen berokkenen? In 1999 hebben wetenschappers van de Cornell University in de Verenigde Staten hier onderzoek naar verricht. Pollen van gewone maïs en van gemodificeerde maïs werden in het laboratorium gevoerd aan rupsen van de monarchvlinder. Een deel van de rupsen die pollen aten van de gemodificeerde plant ging dood, terwijl dit niet het geval was met de rupsen die niet-gemodificeerde pollen aten. Hoewel het Cornell-rapport aangaf dat de rupsen door het Bt toxine waren gedood en dat dit waarschijnlijk ook zou zijn gebeurd in het veld als de toxine als een spray was gebruikt in de context van 'organic farming', was de interpretatie in de media dat genetische manipulatie van gewassen had geleid tot dode vlinders. Een officieel onderzoeksrapport van de us Environmental Protection Agency waarin de kans op contaminatie in het veld en het gevaar voor vlinders als zeer laag werd beoordeeld, had weinig impact. Dat is verbazend omdat in dit rapport ook werd aangegeven dat er voor Bt maïs veel minder biociden nodig waren dan voor reguliere maïs en dat dit als een groot milieuvoordeel kon worden beschouwd. Immers, in dat geval zouden nog meer vlinders het loodje leggen.

Het voorbeeld toont aan dat wetenschappelijke gegevens eenzijdig kunnen worden geïnterpreteerd vanuit een bepaalde visie, in dit geval vanuit het onacceptabel vinden van genetische manipulatie van voedselgewassen. Het is de taak van de onafhankelijke wetenschapper om hier bezwaar tegen te maken en ervoor te zorgen dat bij het formuleren van milieubeleid de resultaten van onderzoek objectief worden gerepresenteerd. In dit geval berustte de onzekerheid over de status van Bt maïs niet op een gebrek aan kennis, maar op het selectief veronachtzamen ervan. Deze discussie laat onverlet dat het ontwikkelen van biologische bestrijdingsmethoden zonder chemicaliën zonder meer te verkiezen valt boven het genetisch manipuleren van in dit geval maïs. We weten immers niet of de corn borer mogelijk op termijn immuun kan worden voor deze toxine. Dit is met veel bestrijdingsmiddelen het geval en dit leidt op zijn beurt tot een uitzichtloze zoektocht naar steeds weer nieuwe stoffen. De conclusie van deze casus is dat een voorkeur voor biologische bestrijding niet mag leiden tot het gekleurd weergeven van informatie die in een andere richting lijkt te wijzen. 


\subsection{PARTICIPATIE DOOR MAATSCHAPPELIJKE GROEPERINGEN}

Bij de menings- en besluitvorming van alle in hoofdstuk 4 onderzochte casussen spelen maatschappelijke groeperingen een belangrijke rol. Tegelijkertijd blijkt er een grote variatie te bestaan in de aard van de participatie. Bij manifeste hinder is er een grote betrokkenheid van de gelaedeerden, die bij de signalering van het probleem steun krijgen van milieugroeperingen. Deze beschikken vaak ook over de expertise die de direct getroffenen ontbeert. Bij abstractere problemen - zoals de ontwikkeling van de vogelstand, het broeikaseffect en de milieuvervuiling door chloormicro's - zijn het veelal de grote milieuorganisaties die de degens kruisen met bedrijfsleven en overheid.

Het belang van milieuorganisaties bij de probleemsignalering en de beleidsvorming is in dit rapport op tal van plaatsen aan de orde geweest. Ook op vele andere beleidsterreinen zijn maatschappelijke groeperingen actief. De vraag is daarom wel opgeworpen of de politieke democratie zou kunnen opgaan in een multiactormodel van besturing en besluitvorming. Eerder is aangegeven wat hiervan de beperkingen zijn. Bij de bespreking van de afzonderlijke casussen in hoofdstuk 4 werden daarover al enige opmerkingen gemaakt. 'Het' multi-actormodel is overigens een groot woord in dit verband; het suggereert dat er een standaardbenadering bestaat van het systematisch inschakelen van de bevolking. Hiervan is allerminst sprake. Waar maatschappelijke groeperingen feitelijk een rol spelen, hebben ze zich veelal moeten invechten om een plaats aan tafel te veroveren. De vorm die deze participatie aanneemt, verschilt van geval tot geval. Niettemin is de invloed van milieugroeperingen groot, in alle casussen waar van participatie in enigerlei vorm sprake is. Deze participatie blijft niet beperkt tot het agenderen van een probleem, maar loopt soms door tot ver in de besluitvorming (Schiphol, chloorhoudende verbindingen). De milieubeweging zoekt die rol niet altijd zelf op, maar wordt ook door overheid en bedrijfsleven gestimuleerd om hen terwille van de haalbaarheid te committeren aan te vinden oplossingsrichtingen. Voor de milieuorganisaties is dit steeds een dilemma: participatie in besluitvorming vergroot de invloed, maar verkleint de bewegingsvrijheid.

\section{Groen poldermodel?}

In het algemeen kan het nuttig zijn constellaties tot stand te brengen waar (milieu-) advocacy groups en onafhankelijke wetenschappelijk onderzoekers met elkaar aan tafel zitten. Het kan leiden tot een verhoogd begrip, een meer gezamenlijke kennisbasis, en een zekere de-radicalisering in de opstelling. In de sociaal-economische beleidswereld is de SER van oudsher het voorbeeld van een dergelijke vorm van institutionalisering (poldermodel). Hier wordt overigens niet zo'n 'zware' vorm van institutionalisering bepleit; 'lichtere' vormen hebben de voorkeur (vgl. Hazeu 2000a: 250; WRR 2002b: 42). In Nederland is wel eens een 'groen poldermodel' bepleit, naar analogie met de institutionele constellatie op sociaal-economisch gebied. Hoewel minder geïnstitutionaliseerd, wordt blijkens de casussen in de praktijk ook vaak zo'n aanpak gezocht of gevolgd. De 
beleidsonzekerheid wordt dan gereduceerd door te streven naar een oplossing die maatschappelijk acceptabel wordt gevonden.

Toch roept deze vorm van streven naar draagvlak ook vragen op, bijvoorbeeld over het democratisch gehalte van de besluitvorming. Het multi-actormodel wringt soms met dat van de vertegenwoordigende democratie. Ook al zouden milieugroeperingen een overtuigende interne democratie kennen (hetgeen niet altijd het geval is), dan nog dient zich de vraag aan naar de invloed die hen toekomt, gegeven de belangen die niet via een milieuorganisatie zijn vertegenwoordigd. Wordt in de ideaaltypische verwoording van stakeholder planning aan de selectie van belanghebbenden een zwaar gewicht toegekend om te voorkomen dat eerder van shareholders sprake is, in de praktijk is dit moeilijk te realiseren. In de casussen is nergens sprake van een uitdrukkelijk selectiemechanisme ten aanzien van groeperingen die wel of niet bij de besluitvormingsprocessen zijn betrokken. Het is ook niet doenlijk om alle in het geding zijnde belangen te identificeren en bij de besluitvorming te betrekken. Een probleem daarbij is bovendien dat degenen die problemen signaleren en degenen die uiteindelijk door concreet beleid getroffen zullen worden, verschillende groepen kunnen zijn. Het zijn dan ook vooral de groepen met een hoog mobilisatiepotentieel, groepen derhalve die gewicht in de schaal van de publieke meningsvorming leggen, die bij de beleidsvorming worden betrokken. Uit het bestuurlijk streven naar haalbaarheid is dit begrijpelijk, uit democratisch oogpunt twijfelachtig. Evenmin blijken er in de casussen expliciete procedures voor het proces van besluitvorming zelf te bestaan.

\section{Afwegingen tussen verschillende waarden}

Zeker in het geval dat het niet meer uitsluitend gaat om het verminderen van milieubelasting, maar om ruimere duurzaamheidsvraagstukken - en er derhalve afwegingen tussen verschillende waarden en belangen in het geding zijn - lijkt de noodzakelijke locus van besluitvorming toch eerder van formeel-democratische aard te moeten zijn dan dat zij de resultante kan zijn van een multi-actorprocedure. In de samenstelling daarvan kan immers nooit recht worden gedaan aan alle in het geding zijnde waarden en belangen. De vertegenwoordigende democratie is in principe juist bedoeld om recht te doen aan of een afweging te maken tussen alle belangen, ook die zich wellicht niet, of nog niet roeren rond een bepaald thema. Ze kent ook aanvaarde procedures voor besluitvorming.

Ondertussen is het voor het parlement lastig om een tussen 'gepassioneerde' betrokkenen bereikt akkoord te negeren en tot een geheel eigen afweging te komen. Men is met zo'n akkoord immers verzekerd van aanvaardbaarheid en haalbaarheid van een oplossingsrichting bij de belangrijke spelers. Toch is dit maar de halve waarheid; de casussen van de twee Europese richtlijnen laten zien dat bij de implementatie zich weer nieuwe groeperingen met andere oordelen manifesteren. Groeperingen die zich sterk maken in de inputfase van het beleidsproces zijn dus niet identiek aan de groeperingen die door de beleidsuitkomst 
worden getroffen. En ook het co2-beleid, dat in belangrijke mate berust op vrijwillig aangegane taakstellingen met groepen bedrijven, zal bij aanscherping onder het Kyoto-Protocol vermoedelijk de beperkingen van de gemaakte afspraken te zien geven.

\section{Overheid moet de betrokkenheid van actoren stimuleren en een publieke taak vervullen}

Via het multi-actormodel zijn de betrokken actoren niet altijd in staat om op eigen kracht tot voor allen bevredigende oplossingen te komen. Soms zijn de tegenstellingen te groot. In de Schiphol-casus kon pas voortgang worden geboekt door tussenkomst van overheid en parlement, die via procedurevoorschriften tijdschema's oplegden. En bij de chloordiscussie werd zelfs expliciet behoefte geuit aan een overheid die knopen doorhakte, in plaats van de 'dialoog tussen doven' te laten voortduren. Hier ligt derhalve een belangrijk probleem. Overheidsbeleid vergt terwille van de haalbaarheid dat de aanvaardbaarheid van de beleidsingreep wordt georganiseerd. Een top-down-benadering waarbij de overheid parlementair geaccordeerd beleid oplegt, kan niet automatisch rekenen op een voor de effectiviteit toereikend draagvlak. De betrokkenheid zal derhalve moeten worden georganiseerd. Participatie is noodzakelijk voor uitwisseling van kennis en argumentaties. Maar dit is iets anders dan een tijdelijke uitbesteding of zelfs 'privatisering' van de publieke zaak, waarvan bovendien allerminst zeker is of onderlinge overreding tot overeenkomsten kan leiden, dan wel of de bereikte overeenkomsten vervolgens ook uitvoerbaar zijn.

\subsection{INTERNATIONAAL MILIEUBELEID EN DE SCHARNIERFUNCTIE VAN DE NATIONALE OVERHEID}

\subsubsection{SCHAALVERGROTING}

De milieuproblemen van de jaren zeventig (lucht, water en bodem) hadden qua schaal bovenal een lokaal en regionaal karakter; de problemen konden dan ook met een relatief succesvol nationaal beleid tegemoet worden getreden. De nieuwe ecologische problemen van klimaatverandering en biodiversiteit zijn fundamenteel anders van aard, in het bijzonder waar het de schaal betreft. Het zijn problemen met een internationaal karakter. De gevolgen zijn minder goed te lokaliseren, waardoor ze niet slechts deelgroepen raken, maar vele, zo niet alle burgers. Dit vereist dat de grote, internationale milieuproblemen ook internationaal worden aangepakt. Met de schaalvergroting van de milieuproblemen zijn dan ook de institutionele niveaus verschoven naar hogere bestuurlijke schalen. Wat de bewerktuiging van het internationale milieubeleid betreft, zijn er vanuit Nederland gezien twee niveaus van belang: het wereldniveau en de internationale afspraken die daar totstandkomen (met name de VN, subpar. 5.4.2), en dat van de EU met zijn regelgeving en coördinatie (subpar. 5.4.3). 
Verschillende van de in hoofdstuk 4 besproken casussen hebben laten zien dat er steeds meer sprake is van een verweving van nationale en bovennationale jurisdicties. De Europese bemoeienis met het milieubeleid wordt steeds intensiever, en ook zijn er in antwoord op Agenda 21 van de vn steeds meer internationale verdragen totstandgekomen ten aanzien van belangrijke milieuvraagstukken. De vrees die eerder heeft bestaan dat de internationalisering van beleid zou leiden tot een race to the bottom, is niet bewaarheid geworden. Eerder is het omgekeerde het geval: de internationalisering heeft er juist toe geleid dat er extra druk wordt gezet op de nationale beleidsvorming. Zo wordt Nederland bijvoorbeeld onder dreiging van zware sancties gehouden aan de uitvoering van aangegane verplichtingen. De casussen van de Vogel- en Nitraatrichtlijn van de EU en het $\mathrm{CO}_{2}$-beleid hebben dat aangetoond. Wilde Nederland eerder nog wel eens uitblinken in het aanvaarden van ambitieuze doelstellingen, gevolgd door een lankmoedige implementatie, doel en implementatie zijn in EU-verband de laatste jaren dichter bij elkaar komen te liggen. Vraagstukken van haalbaarheid, doeltreffendheid en doelmatigheid van de implementatie hebben hierdoor aan belang gewonnen. Sterker dan voorheen zouden deze dan ook meegewogen moeten worden bij de doelbepaling. De overeenstemming die in Brussel wordt bereikt, doet er steeds meer toe. Aan het eenmaal overeengekomen resultaat is de Nederlandse overheid gebonden en een tegenvallende implementatie valt niet langer te compenseren door temporisering van doelstellingen. De beide besproken richtlijnen laten zien hoezeer hierdoor de logic of consequence kan botsen met de logic of appropriateness (March en Olsen 1995). Wanneer 'Brussel' en 'Luxemburg' Nederland houden aan de consequenties van een genomen besluit, wreekt het zich wanneer vooraf onvoldoende aandacht is besteed aan de aanvaardbaarheid en haalbaarheid. Een beroep op rechtmatigheid, omdat het besluit de juiste procedure heeft doorlopen, is niet toereikend. Het is de nationale overheid die door de EU wordt gehouden aan de implementatie en bij een tekortschietende prestatie aansprakelijk wordt gesteld - het gaat nu om een resultaatverplichting, niet om een inspanningsverplichting. Het is derhalve ook de nationale overheid die zich dient te verzekeren van een toereikend draagvlak. Nationale regeringen en parlementen blijven dus een belangrijke rol spelen in de legitimatievorming voor beleid, ook al komt dat beleid in toenemende mate uit Brussel (vgl. ook Scharpf 2002). Dit duiden we aan als de 'scharnierfunctie' die de natiestaat heeft te vervullen in EUverband.

\section{Scharnierfunctie: top-down en bottom-up}

De scharnierfunctie vergt een veel meer pro-actieve mobilisatie van de relevante groeperingen en het parlement met het oog op de besluitvorming in Brussel en de Nederlandse bijdrage daaraan, in plaats van het rekenen op aanvaarding omdat 'het moet van Brussel'. Dat is onvoldoende om legitimatie en draagvlak te vinden. 'Scharnieren' houdt in dit verband enerzijds in dat Nederland in Europa ook z'n inbreng heeft en dat we die zeer goed moeten voorbereiden: wat is voor Nederland haalbaar, aanvaardbaar en doelmatig? Anderzijds moet het nationale beleidsniveau ook vertalen - dat wil zeggen: overtuigen, zendings- en missiewerk doen - en nationaal het draagvlak organiseren. In het vorige hoofdstuk is in 
dit verband al aan de orde geweest dat de Nederlandse overheid daarin bij de casussen over de Vogel- en Nitraatrichtlijnen tekort is geschoten.

Een concrete suggestie in dit verband is om, waar grote milieuorganisaties (en ook het bedrijfsleven en een aantal andere goed georganiseerde lobbygroepen) toegang hebben tot de Brusselse overlegcircuits waarin de beleidsvorming totstandkomt, ook belangrijke instanties op nationaal en lager niveau die de facto belast worden met implementatie en handhaving (met name lagere overheden) in het beleidsvormende circuit al aan tafel te noden. De mogelijke problemen van handhaving en uitvoering, die zich vooral op nationaal en regionaal niveau manifesteren, moeten in de tijd naar voren worden gehaald en al in de fase van beleidsontwikkeling aan de orde komen. Dit kan leiden tot beter implementeerbare regelgeving en een groter commitment van de uiteindelijke uitvoerders en handhavers. De nationale overheid heeft hier een eigen belang bij. Krachtens Europees recht is zij immers verantwoordelijk en aansprakelijk voor de adequate uitvoering van Europese regels, ook indien de uitvoering, gegeven de binnenlandse bestuursstructuur, is overgelaten aan decentrale overheidsorganen of maatschappelijke organisaties. Deze suggestie sluit aan bij de algemenere kritiek die te geven is op de ongelukkige cesuur tussen enerzijds het (cerebrale) 'beleid maken' en anderzijds het (down to earth) 'uitvoeren', welke uitvoering de afgelopen vijftien jaar in het bestuur zo'n nadruk heeft gekregen, met alle gevolgen van dien.

Evengoed zal de normale situatie zijn dat de uitkomst van de onderhandelingen in de EU maar ten dele overeenkomt met de Nederlandse voorkeuren. Ook dan geldt de uitvoeringsplicht. Naar hun aard zullen Europese richtlijnen geen rekening kunnen houden met alle nationale variaties en zullen zij derhalve een betrekkelijk grof karakter hebben. De Nitraatrichtlijn vormt hiervan een voorbeeld. Nederland wordt hier met een bemestingsvoorschrift geconfronteerd dat weliswaar niet onhaalbaar is, maar onvoldoende recht doet aan de nationale differentiatie van bodemsoorten, landgebruik en klimaat. Die zijn echter wel van invloed op de relatie tussen bemesting en het nitraatgehalte van het grondwater. Verder moet Nederland, gegeven het intensieve karakter van de landbouw, in eenzelfde periode een veel ingrijpender verbetering tot stand brengen dan de meeste andere landen. Het meer recht doen aan de lokale situatie bij de implementatieverplichting zou de binnenlandse aanvaardbaarheid, haalbaarheid en ook de effectiviteit ten goede komen. (Een differentiële verplichting per land komt bijvoorbeeld wel tot uitdrukking in de taakstellingen voor emissiereductie in het kader van het $\mathrm{CO}_{2}$-beleid.) Dit klemt temeer daar de nationale staat bij uitstek de instantie is die kan zorgdragen voor een democratische legitimatie van inputs (middelen, instrumenten) van het beleid. Binnen een EU, waarvan de besluitvorming hoofdzakelijk een legitimatie van de outputs (te bereiken resultaten) kent, komt het er derhalve des te meer op aan om de nationale voorzieningen voor inputlegitimiteit maximaal te benutten. 


\subsubsection{INTERNATIONALE SAMENWERKING OP WERELDSCHAAL}

De aandacht voor milieuproblemen op wereldschaal is sterk verbonden met vraagstukken van armoede en (onder)ontwikkeling. Sinds het rapport van de vNcommissie-Brundtland (1987) is 'duurzame ontwikkeling' het overkoepelende motto (Hazeu en Schoonenboom 2002). Bij duurzame ontwikkeling gaat het vanuit ecologisch perspectief om een aantal zeer moeilijk aan te pakken problemen, waarbij de normatieve opvattingen van de betrokkenen bovendien sterk kunnen verschillen. Hoe komen in die constellatie internationale afspraken tot stand die aanvaardbaar, haalbaar en werkbaar zijn? In hoeverre kan worden voorkomen dat wetenschappelijke onzekerheid over causale verbanden meer wordt gepolitiseerd dan nodig en wenselijk is en blokkades opwerpt bij de besluitvorming? En op welke manier kan - ook via het internationale recht - zorg worden gedragen voor een goede naleving, uitvoering en handhaving van internationale afspraken?

In het agenderen van de duurzaamheidsproblematiek hebben declaratieve bijeenkomsten van staatshoofden en regeringsleiders (denk met name aan de VNconferentie van Rio in 1992) een belangrijke mobiliserende functie gehad. Deze fase van erkenning van gemeenschappelijke problemen moet dan worden gevolgd door een fase die bestaat uit een zoektocht naar veelbelovende oplossingen, good practices. Dit gebeurt door de beleidspraktijken van landen systematisch met elkaar te vergelijken en afspraken te maken over concrete doelen. Maar een dergelijke 'neo-voluntarische benadering' (geen bindende voorschriften, maar niet-bindende aanbevelingen) volstaat natuurlijk niet. Integendeel, een tweede keer wordt zo'n benadering al sleets. De 'tien-jaar-na-Rio'-conferentie van Johannesburg 2002 was een vrijwel-mislukking; de Proposed Elements for the Political Declaration van Johannesburg zat vol 'we reaffirm's'. De verklaringen van deze bijeenkomsten moeten dan ook uiteindelijk worden gevolgd door vormen van institutionalisering en verankering. Er moet een schaduw van regulering aanwezig zijn en dus moet er georganiseerd worden. Dat is buitengewoon lastig, want op wereldschaal bestaan er wel wereldproblemen, maar er is geen wereldregering met publiek gezag. Er doet zich dan ook maar zo nu en dan een window of opportunity voor om een stap voorwaarts te zetten.

In dit verband is het ook internationaal een belangrijke voorwaarde dat duurzame ontwikkeling niet over alles en alles tegelijk gaat, maar over de aspecten van ecologische duurzaamheid die het meest problematisch zijn (WRR 2002b). Er moet dus een duidelijke focus worden vastgesteld om te kunnen komen tot vorderingen die ook controleerbaar zijn. Voor de internationale afspraken die hierover worden gemaakt, is het noodzakelijk aanspreekbare, betrouwbare en realistische indicatoren te ontwikkelen. Verder zullen er onafhankelijke inspectie-instituties moeten komen (met name onder de vlag van de vN, zoals voor het toezicht op de Kyotoafspraken al is gebeurd), die hierover openbare rapportages uitbrengen. 
Wat het internationale duurzaamheidsbeleid betreft, is de vraag aan de orde hoe dit zich verder moet ontwikkelen na de conferentie van Johannesburg. Het zal duidelijk zijn dat er over tien jaar niet opnieuw een massaal en veelomvattend 'Johannesburg' moet worden gehouden. Kenmerkend voor besluitvorming in een grote groep (i.c. 180 landen) is dat ze bloot staat aan free riding en parasitair gedrag (Hazeu 2003). De zoekrichting voor verdere beleidsvorming zou daarom moeten zijn om de 'grote groep' terug te brengen tot een verzameling kleinere groepen, waarin wel voldoende sociale controle op elkaar kan worden ontwikkeld om daadwerkelijke stappen af te dwingen. Kortom, om verder te komen zal het 'Olson-probleem' (Olson 1965) moeten worden aangepakt: de 'grote groep' moet worden getransformeerd naar meerdere kleine groepen die op een gezamenlijke noemer gaan samenwerken, concrete afspraken maken, elkaar de maat nemen, en geleidelijk ook mechanismen van sociale dwang en controle gaan ontwikkelen. Er kan daarbij worden gedacht aan jumelages (van bijv. van vier of vijf landen uit verschillende werelddelen) of twinnings (bijv. van een ontwikkeld en een ontwikkelingsland) (WRR 2002b). Uiteraard moeten die kleine groepen niet op een willekeurige basis totstandkomen, maar op grond van een gezamenlijk predominant probleem (bijv. wateroverlast en -vervuiling in delta's), een gezamenlijk belang (bijv. productie versus gebruik van hardhout) of een gemeenschappelijk kenmerk (bijv. grote bevolkingsdruk). Onder die conditie hebben landen 'elkaar wat te vertellen' en is de kans op leereffecten het grootst. De samenwerking moet dus een welvaartsvoordeel opleveren voor de desbetreffende landen, zodat er een endogene incentive-werking is.

\subsubsection{ONTWIKKELINGEN IN HET MILIEUBELEID VAN DE EU}

In tegenstelling tot de $\mathrm{VN}$ is de EU wel een bovennationaal overheidsniveau met publiek gezag. Ze kan wetten en regels (richtlijnen en verordeningen) maken die de nationale staten hebben uit te voeren. Daarnaast maakt de EU de laatste jaren ook gebruik van 'zachtere' vormen van beleid, met name op de terreinen waar ze niet van oudsher actief is, zoals het arbeidsmarkt- en socialezekerheidsbeleid. Dit wordt wel samengenomen onder de open coördinatiemethode (осM) (over de achterliggende concepten zie uitgebreider Atkinson et al. 2002: v-xi). Ook op milieuterrein is er tegenwoordig sprake van meer flexibele beleidsinstrumenten. Hierna volgt een korte schets van de ontwikkelingsgang van het Europese milieubeleid.

\section{Van oudsher: richtlijnen}

Van oudsher is er op milieuterrein er een breed scala van Europese regelgeving. Op dit moment bestaan er meer dan 260 milieurichtlijnen (Henzen 2001). Zo zijn er richtlijnen voor grote stookinstallaties, drinkwater, stedelijk afvalwater, lozing van gevaarlijke stoffen, nitraat, flora en fauna, vogels en habitat, enzovoort. Deze richtlijnen leggen bepaalde doelstellingen vast en kunnen ook de beleidsinstrumenten voorschrijven. Ze kunnen een zware administratieve lasten met zich meebrengen: zowel voor bedrijven om ze na te leven, en voor nationale overheden om de naleving te controleren (zie bijv. de Nitraatrichtlijn; vgl. WRR 2Oo2b: 33-34). 
In de jaren zeventig en tachtig waren het enkele ambitieuze landen (zoals Nederland en Duitsland) die vooropliepen en die 'achterblijvers' (zoals het Verenigd Koninkrijk ) meetrokken naar het vaststellen van hogere standaarden van milieuregulering dan waarover overeenstemming kon worden bereikt op nationaal niveau. Milieubeleid werd een belangrijk aandachtsgebied (Wallace en Wallace 20oo). Belangrijk hierbij was de mate waarin landen met relatief veel milieuregulering in staat waren om hun reguleringsregimes te 'externaliseren' in de richting van de achterblijvers, om hun concurrentiepositie te beschermen (het creëren van level playing fields is immers het zien te verhogen van de productiekosten van je concurrent!).

\section{Trend tot flexibilisering}

De tweede helft van de jaren tachtig en het begin van de jaren negentig werden gekenmerkt door een moeilijker economisch klimaat. Dat had z'n weerslag op het Europese milieubeleid: minder zware regulering; meer ruimte voor individuele lidstaten in de uitvoering. Met name het Verenigd Koninkrijk zette aan tot deze lijn van een meer flexibele regulering, hetgeen ook meer ruimte bood om NGO's in de beleidsontwikkeling te betrekken. In deze periode - enigszins paradoxaal gezien de afnemende maatschappelijke en politieke belangstelling voor milieuproblemen - vond ook meer verankering van milieubeleid plaats in verdragen (Maastricht, Amsterdam, en de daar geregelde gekwalificeerde meerderheidsbesluitvorming). Een ontwikkeling die hiermee verband hield, was de toetreding tot de EU van landen met een hoge mate van milieuregelgeving, zoals Oostenrijk, Zweden en Finland. Het Verdrag van Amsterdam (1997) sprak van: "Where possible member states should be given the freedom to enforce Community policy and regulation through the means which they prefer, taking into account their traditions and legal systems." In concreto leidde dit tot een beweging van richtlijnen met gedetailleerde voorschriften (volgens het command and controlconcept) naar kaderrichtlijnen die meer vrijheid lieten bij het kiezen van de middelen om de gestelde doelen te bereiken. De Commissie en het Europese Parlement staken in op deze verandering van lijn. Het belang ervan was onder meer dat daardoor beter 'lokale kennis' (van bedrijven, maatschappelijke organisaties en lagere overheden) kon worden ingezet om een optimaal resultaat te bereiken (uitgebreider daarover WRR 2002b: 39). Dit kon de acceptatie van regelgeving in de uitvoeringspraktijk vergroten.

Het belang van dit argument zal in de toekomst verder toenemen naarmate nationale overheden in een grotere Unie ieder relatief minder de besluitvorming kunnen beïnvloeden. Nationale overheden zijn steeds meer de uitvoerende arm van de Unie, en zullen dus meer moeten letten op de scharnierfunctie die ze te vervullen hebben. Zoals hiervoor al is benadrukt, kunnen de lidstaten zich niet louter achter 'Europa' verschuilen.

Een andere 'aandrijver' van een zekere noodzaak tot flexibiliteit is dat bij de aanstaande uitbreiding van de EU met een aantal Midden- en Oost-Europese landen zeker zal blijken dat de nieuwe lidstaten niet kunnen voldoen aan alle 
milieurichtlijnen (met verdragen, verordeningen en andere besluiten vormen ze samen het milieu-acquis). Een oplossingsrichting hiervoor is dat de toetredende landen in ieder geval aan de milieurichtlijnen zullen moeten voldoen die direct verband houden met de eisen die de interne markt stelt. Er is dan nog een restacquis waaraan in een afgesproken overgangstermijn zal moeten worden voldaan (WRR 2001: 381-382). Daardoor kunnen er in de uitgebreide Unie op een aantal terreinen - zoals milieu - groepen van 'koplopers' (zoals de Schengenlanden wat betreft grenscontroles zijn geweest) ontstaan die al wel aan alle richtlijnen voldoen, terwijl andere lidstaten worden verplicht daarbij later aan te haken.

Tegelijkertijd met deze flexibilisering binnen de EU wordt in het internationale veld de EU een steeds belangrijkere speler; denk aan de klimaatonderhandelingen in het kader van het Kyoto-Protocol (zie subpar. 5.4.2).

\section{Implementatie (-tekort)}

Wat de implementatie van de EU-milieuregelgeving betreft, is er sprake van een grote variëteit tussen landen en naar gelang de regeling. Implementatietekorten zijn geleidelijk meer indringend op het bordje van de Commissie komen te liggen. Sinds 1983 rapporteert de Commissie jaarlijks over de naleving van de EUmilieuregels. Verder lopen er inmiddels op tal van terreinen procedures tegen lidstaten vanwege inbreuken op die naleving. De Commissie heeft te maken met het gegeven dat de bestuurlijke capaciteit sterk verschilt tussen de verschillende landen van de Unie. Sommige landen zijn in staat op een relatief efficiënte manier de EU-regelgeving nationaal te implementeren; andere hebben daar regelmatig moeilijkheden mee, zoals Italië. Verder ontstaan er soms implementatieproblemen die niet zijn toe te schrijven aan de bestuurlijke capaciteit van een land, maar eerder aan een misfit tussen de reguleringsaanpak van de EU en de bestuurlijke constellatie in een land. Zo speelt in Duitsland dat milieubeleid een bevoegdheid van de Länder is (Sbragia 2000: 306). Nederland is in het implementeren van de EU-milieuregels niet (meer) 'het braafste jongetje van de klas', maar loopt zeker ook niet achteraan. In het algemeen is de indruk dat Nederland tegenwoordig een 'redelijke middenmoter' is.

\section{Meer flexibele bestuursfilosofie}

In de loop van de jaren negentig is er een debat ontstaan over de bestuursfilosofie die ten grondslag moet liggen aan het Eu-beleid: valt de keus op command and control of is er ook ruimte voor meer flexibele markt- en informatiegerichte sturingsinstrumenten? Bij het eerste is de aansturing gericht op de middelen (inputs); bij het laatste op de doelen (outputs). Het eerste vereist gedetailleerde voorschriften van de Commissie; het laatste laat meer ruimte aan de lidstaten in de uitvoering. In het Fifth Action Programme (1993-2000) is de verschuiving van command and control naar een meer flexibele uitvoering tot uitdrukking gebracht. De nieuwe accentuering (want - let wel - de vele bestaande richtlijnen worden niet vervangen of ontmanteld) heeft tot doel om een impuls te geven aan een grotere doelmatigheid en eigen verantwoordelijkheid van de lidstaten. Dit is een logische ontwikkeling in een groter wordende Unie. Bovendien is het een 
trend die in de jaren negentig vrijwel overal in het bestuur opgeld is gaan doen. Het biedt landen ook ruimte om milieudoelstellingen te verwezenlijken door vrijwillige overeenkomsten, zoals (de Nederlandse) convenanten. Zo realiseerde de Europese Commissie ook, in het kader van het Kyoto-Protocol, een vrijwillige overeenkomst om de kooldioxide-uitstoot van nieuwe auto's terug te brengen. Voor de totstandkoming daarvan was uiteraard wel het Kyoto-Protocol doorslaggevend, hetgeen de samenhang tussen vrijwilligheid en verplichtendheid illustreert.

Op milieuterrein kunnen deze ontwikkelingen in de richting van flexibilisering, vrijwilligheid en het betrekken van NGO's en andere actoren, enigszins worden vergeleken met de recente opkomst van de ocM op sociaal-economisch gebied, hoewel die op dit laatste gebied vooral is ingegeven door het gegeven dat de EU niet of nauwelijks competenties terzake heeft. Bij die vergelijking is het nuttig om in te zien dat voor het milieudomein geldt dat, voorzover de milieuproblemen op wereldschaal spelen, beleidsoplossingen (of het nalaten daarvan) in het ene land een veel grotere invloed hebben dan op het andere. Anders gezegd: de externe effecten van het nationaal beleid zijn bij internationale milieuproblemen vermoedelijk groter dan die van het sociaal-economische beleid. Om ook op Europees niveau een goed milieubeleid te kunnen bereiken, kan een ocM-achtige benadering op milieuterrein dus slechts een beperkte rol spelen. En waar het een rol kan spelen, zal er uiteindelijk ook in kaderrichtlijnen voorzien moeten worden in hardere afspraken met geloofwaardige sanctiemechanismen. In dit licht is ook belangrijk dat in 1993 het Europees Milieu Agentschap in Kopenhagen is opgericht met als taak het verzamelen en verspreiden van informatie op milieugebied.

In het raadsrapport Slagvaardigheid in de Europabrede Unie (WRR 2003c) heeft de raad gepleit voor een breed scala van bestuursvormen binnen Europa, mede gezien de eigen aard van verschillende sectoren, en voor meer mogelijkheden van variatie binnen de communautaire methode. In het verlengde hiervan kan het volgende worden gesteld. Gegeven de aard van het milieubeleid zal in Europees verband het model van open coördinatie hier een beperkte rol kunnen spelen. Doelen en geloofwaardige sanctiemechanismen zullen op Europees niveau in kaderrichtlijnen moeten worden vastgelegd. Dit gegeven versterkt de noodzaak om de scharnierfunctie van de nationale overheid meer gewicht te geven. Binnen dit kader zijn er goede redenen om de op Europees niveau ingezette lijn te versterken, waarbij nationale overheden zoveel mogelijk vrij worden gelaten in de wijze waarop doelen moeten worden bereikt en waarbij aldus de variatiemogelijkheden binnen de communautaire methoden zoveel mogelijk worden benut.

\section{$5 \cdot 5$ CONCLUSIES}

De milieubeleidsproblematiek van de toekomst: de wicked problems

Het milieubeleid krijgt steeds meer betrekking op de wicked problemen, zoals het broeikasprobleem, de problematiek van chemische verontreiniging en de biodiversiteit. Deze problemen gaan gepaard met vele onzekerheden. Lang niet alle 
causaliteiten zijn volledig kenbaar. Gevolgen spelen op lange termijn. Bovendien zijn het sluipende ontwikkelingen. Het beleid zal zich daardoor minder kunnen baseren op een breed gedeeld probleembesef. Bij direct ervaren hinder zijn mensen en instellingen immers gemakkelijker bereid gedragsbeïnvloedende maatregelen te aanvaarden dan bij weliswaar aangezegde, maar 'onzichtbare' problemen.

De casussen die in deze studie zijn behandeld, laten een staalkaart aan benaderingen zien die in Nederland werden en worden gehanteerd om tot een definitie en oplossingsrichting te komen van milieuproblemen, overigens niet allemaal wicked problemen. In lang niet alle gevallen is het probleem inderdaad opgelost, maar in de meeste gevallen lijkt de richting ervan langzamerhand duidelijk te zijn. Evenmin is, gezien de fase waarin de verschillende casussen zich bevinden, al in positieve zin een antwoord te geven op de vier kernvragen van goed beleid uit hoofdstuk 3 (te weten rechtmatigheid, doelmatigheid en doeltreffendheid, politieke haalbaarheid, en maatschappelijke aanvaardbaarheid). Zo is nog allerminst duidelijk of de zich aandienende beleidsmaatregelen ten aanzien van chloorhoudende verbindingen, Schiphol, de Vogelrichtlijn en het Kyoto-Protocol inderdaad haalbaar zijn. In het geval van de Nitraatrichtlijn is het antwoord al wel duidelijk: Nederland is niet in de opgelegde doelstellingen geslaagd.

De twee bronnen voor het vinden van een antwoord op de vier vragen, kennis en participatie, spelen bij alle casussen een rol, zij het dat het beroep erop van geval tot geval verschilt. De kennisvraag is in het geval van Rijnmond en de Vogelrichtlijn gemakkelijker te beantwoorden dan bij bijvoorbeeld Schiphol, chloorhoudende verbindingen en klimaatverandering. In alle casussen zijn vormen van overleg van belang, zonder dat er een zwaar geïnstitutionaliseerd 'groen poldermodel' wordt vormgegeven. Bij de beide richtlijnen van de Eu blijken flinke tekortkomingen in het pro-actief beleid een stem te geven aan die groeperingen wier gedragsverandering juist het oogmerk van het nieuwe beleid is.

Het belang van kennis als grondslag voor de bewustwording van de problemen en de legitimatieverwerving voor het beleid ten aanzien van de wicked problemen is bijzonder groot. Zonder die kennis bestaat er immers in het geheel geen 'voorstelling' van deze milieuproblemen: de gevolgen worden eerst in de - vaak verre toekomst zichtbaar, kunnen zich bovendien ver van ons land manifesteren, en zijn ook nog met onzekerheid omgeven. Daardoor wordt het van groot belang hoe die kennis wordt verkregen, hoe zij maatschappelijk wordt gemobiliseerd en wordt ingebed in het beleidsproces, en hoe in het beleid met de vele onzekerheden wordt omgegaan.

\section{Kennismobilisatie, risicoanalyse en voorzorgsbeginsel}

De belangrijke rol van kennis voor het onderkennen en oplossen van de persistente milieuproblemen stelt hoge eisen aan de mobilisering van die kennis in het maatschappelijke debat en in het beleid. Omdat de percepties van de betrokken partijen vaak sterk uiteenlopen, zal iedere partij een beroep doen op expertise die 
het eigen standpunt ondersteunt. Het is dan van het grootste belang dat de overheid toeziet op de veronafhankelijking van reliable knowledge (wetenschappelijk valide kennis), en tevens werkt aan het ontstaan van shared knowledge, kennis die door alle betrokkenen als betrouwbaar wordt aanvaard. Dit geldt ook voor kennis omtrent het domein dat als onbekend moet worden beschouwd. In de casussen blijken verschillende vormen van objectivering van kennis van betekenis te zijn geweest. Het IPCC is een voorbeeld van een poging in internationaal verband om de kennisontwikkeling te evalueren en recht te doen aan tegengestelde verklaringen.

In een aantal gevallen heeft een eenzijdig kennisperspectief ten grondslag gelegen aan de vaststelling van het beleid. Zo is de Nitraatrichtlijn vastgesteld zonder dat bij de Nederlandse voorbereiding op de besluitvorming voldoende rekening is gehouden met het agrarische perspectief en de kennis die van daaruit voor de vaststelling van het beleid kon worden bijgedragen. Daardoor zijn suboptimale oplossingen gekozen die op grotere weerstanden en dus uitvoeringsproblemen zijn gestuit dan nodig was geweest.

Een kernpunt is dat voor de definitieve besluitvorming een open oriëntatie moet plaatsvinden. Daarin moet de vraag aan de orde zijn of de wetenschappelijke kennis die wordt gebruikt op voldoende onafhankelijke wijze is verkregen, en of die wetenschappelijk gevalideerde kennis ook toepasbaar en aanvaardbaar is als gedeelde kennis binnen de handelingsperspectieven van de partijen die belang hebben bij de besluitvorming.

De risicoanalyse en het voorzorgsbeginsel worden beide gebruikt om met kennisen beleidsonzekerheid om te gaan. De tegenstelling tussen beide wordt vaak benadrukt. Zij kunnen echter beter met elkaar in verband worden gebracht, omdat de een als aanvulling op de ander gebruikt kan worden. De risicoanalyse gebiedt tot een afweging van risico's. Die (gepercipieerde) risico's moeten worden afgewogen in de politieke besluitvorming. Daarbij speelt ook de gewenste mate van risicomijding een rol. Bij deze analyse kan blijken dat de kennis ontoereikend is om voldoende zekerheid te verschaffen over belangrijke relaties en effecten. Dan ontbreken de benodigde gegevens over de afweging van de risico's. In die gevallen kan de afweging tussen het bekende en het onbekende nopen tot voorzorg. Daar, aan de 'rand van de kennis', kan de politiek voor voorzichtigheid kiezen. Het voorzorgsbeginsel is derhalve een meer normatief concept dat wordt ingegeven door risicomijding bij grote onzekerheid.

Zo gezien, is het de vraag hoe vruchtbaar het is om risicoanalyse en voorzorgsbeginsel tegenover elkaar te plaatsen bij de benadering van (de nieuwe) milieuproblemen. Het voorzorgsbeginsel kan immers worden gezien als een element dat kan worden ingevoegd in de risicoanalyse. Het is een punt aan het einde van het spectrum, waar een grote onzekerheid gepaard gaat met een hoge riscoaversie. Door het voorzorgsbeginsel op die wijze in het verlengde van de risicoanalyse te plaatsen, voorkomt men de indruk dat beide elkaar uitsluiten. Het extra dat het 
voorzorgsbeginsel in aanvulling op de risicoanalyse in deze benadering biedt, is dan de toevoeging van een normatief element ingeval onvoldoende kennis aanwezig is voor de inschatting van risico's. Dat normatieve element bestaat uit risicomijding ingeval van onzekere, maar mogelijk ernstige of onherstelbare milieuschade.

Uit deze positionering van het voorzorgsbeginsel blijkt ook zijn kwetsbaarheid. Het kan ten onrechte de indruk wekken dat een verantwoorde oplossing is bereikt, zodat het stimulansen tot verder onderzoek wegneemt. Maar omdat de gekozen oplossing alleen verantwoord is bij gebreke van voldoende kennis, zou verder onderzoek juist moeten worden nagestreefd om tot een periodieke herwaardering van het beleid op basis van nieuwe onderzoeksresultaten te kunnen komen.

Daar komt bij dat een beroep op het voorzorgsbeginsel een zorgvuldige analyse vereist. Wanneer bijvoorbeeld een bepaald handelen uit voorzorg achterwege wordt gelaten, moet wel worden nagegaan welk alternatief dan wordt gekozen. De casus van het boren in de Waddenzee maakt dat duidelijk: indien men op grond van de onzekere gevolgen voor het milieu niet naar gas wil boren, kan het sterk van het alternatief afhangen hoe men dit moet beoordelen. Indien dat gezocht wordt in een navenante beperking van het energiegebruik zal dit anders zijn dan indien als alternatief energie van elders wordt betrokken. In dat laatste geval moeten ook de milieuconsequenties daarvan in de beschouwing worden betrokken. Men bedenke daarbij dat ook het afzien van verandering of innovatie, dus 'niets doen', risico's en onzekerheden kan impliceren. De voorkeur voor handhaving van de status quo om risico's te vermijden veronderstelt dat men bekend is met de onzekerheden die dat met zich meebrengt. Maar dat is onjuist.

\section{Betrokkenheid van maatschappelijke actoren}

De participatie van maatschappelijke actoren is bij de nieuwe milieuproblemen van grote betekenis en is ook nodig om de overheid onder druk te houden. Wel dienen de verantwoordelijkheden goed te worden afgebakend. Voor de kennisverwerving en het verkennen van mogelijke oplossingen is participatie van wezenlijke betekenis. Ook voor de legitimatie en de uitvoering van het beleid geldt dat een actieve wisselwerking met degenen die door het beleid worden geraakt, van groot gewicht is. De eigen verantwoordelijkheid van de overheid moet vooropstaan bij de besluitvorming zelf, bij het toezien op de handhaving van het beleid, en bij de steeds belangrijker inbreng in de internationale besluitvorming.

Een en ander vergt een scherpere markering van de overheidsrol in de verschillende onderdelen van beleidsvoering. In de fase van beleidsoriëntatie is een actieve, open consultatie onder regie van de overheid geboden. Hoofdstuk 4 toont aan dat er tal van variaties van een 'groen poldermodel' bestaan. In het verlengde van eerdere rapporten van de raad (WRR 2002b; 2003a) kan worden gesteld dat een zware institutionalisering, zoals een permanente vertegenwoor- 
diging van actie- en lobbygroepen in adviesorganen, hiertoe niet het goede middel is. Wezenlijk is wel dat de overheid als regisseur het oriënterend karakter van deze beleidsoriëntatie bewaakt en mede door het verschaffen van adequate informatie bevordert dat alle relevante kennis, expertise en argumenten, waaronder ook de inbreng van indirect belanghebbenden, op een transparante wijze op tafel komt. In deze fase gaat het om een responsieve overheid die ontvankelijk is voor het geheel van relevante argumenten en deze in het afwegingsproces betrekt. Dat geldt niet voor de daaropvolgende fase. De besluitvorming, de daadwerkelijke afweging van waarden en van de in het geding zijnde belangen, blijft een eigen verantwoordelijkheid van de overheid, gegeven haar unieke democratische mandaat voor de besluitvorming en voor de bepaling van het publieke belang. Ook hier geldt de eis van transparantie: de overheid moet duidelijk (kunnen) maken hoe zij het geheel van de in de vorige fase naar voren gebrachte argumenten heeft gewogen.

Een goede handhaving van het beleid van de inmiddels beheersbare problemen op nationaal en lager niveau, vormt een belangrijke voorwaarde voor versterking van het probleembesef voor de hardnekkige, overgebleven en voor de nieuwe problemen. Goede handhaving helpt de burger duidelijk te maken dat milieubeleid loont. De overheid moet daarom laten zien dat ze het milieubeleid serieus neemt, zeker als ze burgers en bedrijven wil motiveren ook hun rol te spelen. Als burgers zien dat hun directe leefomgeving zichtbaar beter wordt, zullen zij zich ook eerder betrokken voelen bij de meer complexe problemen 'ver van hun bed'. Dit dient voor de overheid een reden te meer zijn om de handhaving van het milieubeleid op een hoger niveau te brengen, ook om beleidsleren te stimuleren.

Van belang is ook de aard van de regels die worden vastgesteld. Juist de nieuwe en hardnekkige milieuproblemen vragen om gedragsverandering van zeer velen. Strakke regelgeving waarvan de zin niet wordt begrepen zou de overheid voor ongekende handhavingsproblemen stellen. Zij zouden er ook toe kunnen leiden dat private actoren hun eigen verantwoordelijkheid inruilen voor het tevreden houden van de overheid, en het aftasten van de grenzen van wat wordt toegelaten. Om tot een uitvoerbaar en effectief beleidsresultaat te komen, is het voor de overheid zaak het potentieel van experimenteren en leren van de private sector te benutten. Dat sluit niet uit dat vervolgens, en soms ook van de aanvang af, strakkere regulering nodig is.

\section{De scharnierfunctie van de nationale overheid}

Waar milieubeleid in toenemende mate op internationaal niveau wordt vastgesteld en op nationaal en lager niveau uitgevoerd, ligt de belangrijkste opgave van de nationale overheid in het op een geloofwaardige wijze combineren van de verschillende rollen die juist de nationale overheid op alledrie de niveaus speelt. Dit is de kern van wat hiervoor als de scharnierfunctie van deze overheid is aangemerkt. Een initiërende en medebepalende rol van de nationale overheid in internationale gremia is van essentieel belang om invloed uit te oefenen op de hier geldende milieuregels. Tegelijkertijd is die rol slechts geloofwaardig als zij 
ook in de vervolgfase zorgt voor adequate uitvoering van de aangegane verplichtingen. Dit op elkaar betrekken van buitenlands en binnenlands beleid vraagt meer dan voorheen expliciete beleidsaandacht van de nationale rijksoverheid.

Dit aandachtspunt vergt een vertaalslag in beide richtingen. Beleidsontwikkelingen op internationaal niveau moeten worden geherformuleerd binnen de eigen Nederlandse context, zodat ook burgers, bedrijven en instellingen (die internationaal niet altijd goed zijn vertegenwoordigd) in een vroegtijdig stadium bij de beleidsontwikkeling worden betrokken. Maar anderzijds moet ervoor worden gezorgd dat de Nederlandse inbreng in het internationale oriënterende beraad wordt gevoed door vroegtijdig beraad op nationaal niveau. Voordat in internationaal verband besluiten worden genomen, moet een goed zicht bestaan op de aanvaardbaarheid, haalbaarheid en doelmatigheid van de voorgenomen maatregelen in de Nederlandse context. Wordt in deze fase nagelaten wat hiervoor over de kennisverwerving in nationaal verband is gezegd, dan kan blijken dat Europese besluiten onomkeerbaar zijn, maar op grote en onverwachte weerstanden en uitvoeringsproblemen stuiten. Eerdere kennis daarover had voor alternatieven kunnen zorgen die inmiddels buiten bereik zijn gekomen.

Specifieke aandacht vraagt hierbij het op elkaar betrekken van beleidsvorming en -uitvoering in de Europese arena. Voor de bepaling van de Nederlandse inbreng gaat het niet alleen om de vraag of een Europees voorstel globaal, op het niveau van de doelen, aansluit op het geldend Nederlands beleid. Ook geldt dat de mogelijke repercussies op het niveau van de Nederlandse structuur en cultuur van het eigen binnenlandse beleid vooraf moeten worden meegewogen in de beleidsinbreng op hoger niveau. De eigen verantwoordelijkheid van de nationale overheid voor de nakoming van internationaal aangegane verplichtingen kan soms vragen om een herziening van decentrale en horizontale structuren in het binnenlands beleid, die de rijksoverheid verhinderen haar verantwoordelijkheid na te komen.

Het nadeel van strakke regulering, zoals die van oudsher in de EU op milieuterrein voorkomt, is dat de inputlegitimatie van het beleid te beperkt is, en dat bovendien iteratieve processen tussen beleidsvorming en -implementatie nauwelijks in deze structuur zijn in te passen. Gezien de vorige punten, en ook in aansluiting op de raadsrapporten Naar een Europabrede Unie (WRR 2001) en Slagvaardigheid in de Europabrede Unie (WRR 20O3C), betekent dit dat niet kan worden volstaan met het stellen en handhaven van regels. In het EU-beleid gericht op de nieuwe generatie milieuproblemen dienen ook de mogelijkheden te worden geëxploreerd voor internationale beleidsontwikkeling met meer ruimte voor gevarieerde uitvoering en bijbehorende leerprocessen op de lagere niveaus. Daarbij hoort ook het (beter) betrekken van de nationale parlementen om te komen tot een betere legitimering van het beleid - het punt dat juist zo lastig is bij deze problemen. Ook het vroegtijdig betrekken van lagere overheden en andere (publieke) handhavers in de besluitvorming is van belang om te komen tot een uitvoerbaar beleid. 
In het laatstgenoemde raadsrapport (WRR 2003c) heeft de raad gepleit voor een breed scala van bestuursvormen binnen Europa, mede gezien de eigen aard van verschillende sectoren, en voor meer variatiemogelijkheden binnen de communautaire methode. In het verlengde hiervan kan het volgende worden geconcludeerd. Doelen en geloofwaardige sanctiemechanismen zullen bij milieubeleid op Europees niveau in kaderrichtlijnen moeten worden vastgelegd. Dit gegeven versterkt de noodzaak om de scharnierfunctie van de nationale overheid meer gewicht te geven. Binnen dit kader zijn er goede redenen om de op Europees niveau ingezette lijn te versterken, waarbij nationale overheden zoveel mogelijk vrij worden gelaten in de wijze waarop doelen moeten worden bereikt en waarbij aldus de variatiemogelijkheden binnen de communautaire methoden zoveel mogelijk worden benut. De spanningen tussen enerzijds de eisen van internationaal beleid en anderzijds de eigen binnenlandse structuur en cultuur van beleid kunnen daardoor afnemen. Bij globale kaderstellende regels kunnen de nationale overheden effectiever gebruikmaken van de eigen bestuursstructuur en -cultuur in hun land. Gedetailleerde Europese regels, die ook het middelenniveau betreffen, grijpen diep in op een land als Nederland met, zeker op milieuterrein, een relatief gedecentraliseerde en horizontale bestuursstructuur en -cultuur. Dergelijke regels vragen om een zware bestuurlijke aanpassing en inspanning. Bij een globalere Europese regelgeving kan daarentegen ook beter gebruik worden gemaakt van specifieke kennis en expertise op nationaal en lager niveau (vgl. WRR 2003a: 220 e.v.). Er blijft dan meer ruimte voor reële samenspraak tussen overheid en betrokkenen op uitvoeringsniveau.

\section{Ten slotte}

De nieuwe generatie wicked milieuproblemen veronderstelt processen van 'beleidsleren voor de fouten uit'. Dit stelt hoge eisen aan kennis, bestuur en samenleving en hun voorstellingsvermogen. Van oudsher behelst het beleid het reageren op problemen die men in de samenleving met het blote oog heeft zien ontstaan. Wicked problemen zijn echter bij uitstek abstract, ver weg, en niet zintuiglijk waarneembaar. Er is dus geen sprake van een direct mobiliserende werking op burgers. Wanneer deze problemen zich werkelijk voordoen, kan het nemen van maatregelen te laat komen. Voor beleidsmakers betekent dit dat kennis een cruciale bron is voor het voeren van beleid. Zonder de aanwezigheid van een breed gedeelde kennisbasis ontstaat niet het gevoel van urgentie dat nodig is de langetermijnmilieueffecten een plaats te geven in de afweging tegen andere belangen. Het kan voorkomen dat de getroffen preventieve milieumaatregelen niet voldoende effect sorteren en dat zich een ramp voordoet of dat er ernstige gevaren dreigen. Dergelijke gebeurtenissen bieden wel de kans om het momentum te gebruiken voor ingrijpende beleidsdoorbraken die onder normale omstandigheden onbereikbaar zijn.

Het nieuwe milieubeleid moet als het ware anticiperen op rampen die zich - bij succesvol beleid - niet zullen voordoen. Dit is de essentie van 'leren voor de fouten uit'. Beleidsleren omvat een proces van aanpassing van beleidsdoelstellingen en -instrumenten in het licht van ervaringen in het recente verleden en aan 
de hand van nieuwe inzichten. Zoals we in de casussen hebben kunnen waarnemen, worden processen van beleidsleren gedreven door een ervaring of perceptie van nalatigheid of falen, waardoor een behoefte aan verbeteringen ontstaat en het zoeken naar oplossingen begint of wordt versterkt. Uitgaande van de initiële onkenbaarheid van de belangrijke causale fatoren achter wicked problemen, maken beleidsmakers keuzen en nemen zij beslissingen in een proces van trial and error. Hierbij neigen beleidsmakers ertoe hun ervaring en kennis te baseren op de vorige crisis. Geplaagd door een kort geheugen, bestaat de neiging tot het nemen van ad-hocmaatregelen, waardoor soms de problemen verergeren. In theorie zouden beleidsmakers met onaangekondigde crises rekening moeten houden ('regeren is vooruitzien') en een strategie moeten ontwerpen voor problemen die zouden kunnen voordoen. In de praktijk echter hebben politici, beleidsmakers en hun adviseurs geen scherpe en mobiliserende voorstellingen en beelden van de nieuwe generatie milieurisico's, mede omdat alle middelen en mensen al zijn ingezet voor het oplossen van de huidige generatie milieuproblemen en het begrijpen van de vorige crisis. Bovendien voedt het relatieve succes van staand milieubeleid het zelfvertrouwen. Dat kan leiden tot zelfgenoegzaamheid en stilstand, en maakt blind voor nieuwe bedreigingen. Voor de nieuwe generatie van wicked milieuproblemen is het van doorslaggevend belang of beleidsmakers zich een mogelijk falen kunnen inbeelden en of zij in staat zijn een adequate voorstelling te maken van een 'nieuwe generatie'-milieuramp. Met behulp van scenariostudies zouden zij daartoe de risico's en kansen van toekomstige milieuproblemen moeten verkennen om vervolgens voorzorgsmaatregelen te treffen en bestuurlijke daadkracht te ontwikkelen. Dit type anticiperend beleidsleren voor problemen die op lange termijn spelen is overigens niet louter van belang voor het terrein van het milieu. In het rapport Generatiebewust beleid (WRR 1999) is aangegeven dat zich op verschillende andere beleidsterreinen een vergelijkbare problematiek voordoet. Gedeelde kennis over problemen die zich in de toekomst kunnen voordoen, kunnen het beleid wel degelijk in sterke mate sturen. Zo is de bewustwording van de gevolgen van de vergrijzing voor de collectieve lasten van grote invloed op de huidige beslissingen over het financieringstekort. Voor de Europese discussie over de pensioenstelsels geldt hetzelfde. Specifiek voor het milieubeleid is wel dat de problemen met een veel grotere onzekerheid zijn omgeven. Dat doet een groter beroep op het beschikbaar komen en omgaan met kennis. De vroege uitwisseling van soms speculatieve inzichten kan het mogelijk maken dat partijen met verschillende normatieve oriëntaties en belangen zich in een vroeg stadium richten op het 'gezamenlijk verwerken van onplezierige feiten'. Het vergt ook afwegingen in geval van voortdurende onzekerheid. De ruimte voor anticiperend beleidsleren krijgt de overheid alleen wanneer zij kan steunen op breed gedeelde kennis. Het is mede haar taak daarvoor te zorgen. 


\section{LITERATUUR}

Abma, T. (2001) 'Narratieve infrastructuur en fixaties in beleidsdialogen. De Schipholdiscussie als casus', Beleid en Maatschappij, 28.

Addiscott, T.M. and N. Benjamin (200o) 'Are you taking your nitrate?’ Food Science and Technology Today 14 (2).

Algemene Rekenkamer (2001) Invoering mineralenaangiftesysteem, Tweede Kamer, vergaderjaar 2000-2001, 27825, nrs. 1-2.

Algemene Rekenkamer (2002) Bestrijding uitstoot broeikasgassen, Tweede Kamer, vergaderjaar 2001-2002, 27825, nrs. 1-2.

Arentsen, M.J., J.Th.A. Bressers en L.J. O’ Toole (1999) 'Omgaan met onzekerheid in het milieubeleid: Een analyse met illustraties uit de Nederlandse en Amerikaanse beleidspraktijk', Beleidswetenschap 4: 375-399.

Asselt, M.B.A. van (200o) Perspectives on uncertainty and risk: The prima approach to decision support, Dordrecht: Kluwer Academic Publishers.

Atkinson, T., B. Cantillon, E. Marlier en B. Nolan (2002) Social indicators. The EU and social inclusion, Oxford: Oxford University Press.

Backes, Chr.W. (1995) 'Implementatie van de Habitatrichtlijn in het Nederlandse natuurbeschermingsrecht', Milieu en Recht 11: 216-221.

Backes, Chr.W. (200o) Vogel- en Habitatrichtlijn - een rode doek voor de gemeenten, De Gemeentestem, 1121: 297-305.

Backes, Chr. and G. Betlem (1999) Integrate pollution prevention and control. The directive from a comparative legal and economic perspective, The Hague/London/Boston: Kluwer Law.

Backes, Chr.W., J. Ponten en F. Neuman (1999) Gemeenten en de Vogel- en Habitatrichtlijn, Preadvies Vereniging Milieurecht, Den Haag: Boom Juridische Uitgevers.

Backes, Chr. et al. (2002) Codificatie van milieurechtelijke beginselen in de Wet milieubeheer, Den Haag: Boom Juridische uitgevers.

Barents, R. (1997) Het Verdrag van Amsterdam en het Europees gemeenschapsrecht, de materieelrechtelijke en institutionele veranderingen', SEW 10: 351-365.

Beck, U. (1992) Risk society: Towards a new modernity, London: Sage.

Bekkers, V.J.J.M. en J.M. Verschuuren (1998) 'Juridische dilemma's bij coproductie in het milieubeleid en de mogelijke rol van de wetgever', Regelmaat 2: 55-66.

Berends, W. en D. Stoppelenburg (1990) Van keukenzout tot gifcocktail, Amsterdam: Vereniging Milieudefensie.

Bergh, J.C.J.M. van den (2002) 'Economie van klimaatbeleid: kritiek en alternatief', Economisch Statistische Berichten 87, 4350: 184-187.

Berkhout, G. (2003) Dossier Schiphol. Relaas van een falend democratisch proces, Den Haag: A.J. Berkhout.

Bont, C. de (200o) Tweeduizend jaar bewoning door waterbeheer in het Delftse, Walburg Pers.

Bovenberg, A.L. en C.N. Teulings (1999), 'Op zoek naar de grenzen van de staat: Publieke verantwoordelijkheid tussen contract en eigendomsrecht', blz. 19-137 in: W. Derksen et al., Over publieke en private verantwoordelijkheden, WRR, V105, Den Haag: Sdu Uitgevers. 
Coenen, F.H.J.M. en A. Halfacre (2000) 'De verdeling van milieueffecten en milieurisico's over de Nederlandse bevolking als beleidsprobleem: Environmental justice in Nederland', Beleidswetenschap 4: 316-339.

Cowles, M.G. and M. Smith (eds.) (2000) The state of the European Union. Vol. 5: Risks, reform, resistance and revival, Oxford: Oxford University Press.

Deutsch, K.W. (1966) Nerves of government, New York: Free Press.

Dewey, J. (1960) The quest for certainty, New York: G.P. Putnam's Sons.

Dietz, F.J., W.A. Hafkamp en J. van der Straaten (1994) Basisboek milieu-economie, Meppel: Boom.

Douglas, M. and A. Wildavsky (1982) Risk and culture: Essays on the selection of technical and environmental dangers, Berkeley: University of California Press.

Drupsteen, Th.G. (1999) 'Kroniek van het milieurecht', Nederlands Juristenblad 31: 15311539 .

Drupsteen, Th.G. (2000) 'Het preventiebeginsel', Milieu en Recht 9: 216-222.

Drupsteen, Th.G. (2001) 'Weg met het voorzorgbeginsel?', Milieu en Recht 7/8: 195.

Drupsteen, Th.G. et al. (1998) De toekomst van de Wet milieubeheer, Deventer: W.E.J. Tjeenk Willink.

Dryzek, J.S. (1990) Discursive democracy: Politics, policy, and political science, Cambridge: Cambridge University Press.

Eeten, M. van (1999) Dialogues of the deaf: Defining new agendas for environmental deadlocks (proefschrift), Delft: Eburon.

Elster, J. (ed.) (1998) Deliberative democracy, Cambridge: Cambridge University Press.

Elzen, M. den en A. de Moor (2001) An updated evaluation of the Bonn Agreement: incorporating the Marrakech Accords, RIVM Rapport 728001017, Bilthoven: RIVM.

Etzioni, A. (1968) The active society, New York: Free Press.

Europese Commissie (200o) Mededeling van de Commissie over het voorzorgsbeginsel /Communication on the Precautionary Principle, Brussel, 2 februari 2000, com 2000.

Europese Commissie (2001a) Europese strategie voor duurzame ontwikkeling, Brussel.

Europese Commissie (2001b) Strategie voor een toekomstig beleid voor chemische stoffen, com (2001) 88 def. Witboek van de Commissie van de Europese Gemeenschappen, 27 februari 2001.

Evaluatiecommissie Wet milieubeheer (2002) Gedogen in het milieurecht, rapport ecwm 2002/6, Den Haag: Ministerie van vrom.

Faure, M. (1998) 'Harmonisation of environmental law and market integration: Harmonisation for the wrong reasons?’, European Environmental Law Review 6: 169-175.

Folmer, H. (2001) 'Europees milieubeleid; afwijken wordt gedoogd', Economisch Statistische Berichten 240-243.

Functowicz, S.O. and J.R. Ravetz (1990) Uncertainty and quality in science for policy, Dordrecht: Kluwer.

Functowicz, S.O. en J.R. Ravetz (1992) 'Three types of risk assessment and the emergence of post-normal science', blz. 251-273 in S. Krimsky en D. Golding (eds.) Social theories of risk, Westport: Praeger.

Furedi, F. (1997) Culture offear, London: Continuum.

Gestel, R.A.J. van en J.M. Verschuuren (2000a) 'Alara: minimumregel of beginsel met aspiraties?', Milieu en Recht 3: 56-63. 
Gestel, R.A.J. van en J.M. Verschuuren (200ob) 'Duurzaam ondernemen, naar een nieuwe generatie milieuwetgeving’, Nederlands Juristenblad 40: 1949-1955.

Gezondheidsraad (1997) Hormoonontregelaars in de mens, rapport 1997/o8, Rijswijk: Gezondheidsraad.

Gezondheidsraad (1999) Hormoonontregelaars in ecosystemen, rapport 1999/13, Den Haag: Gezondheidsraad.

Graaf, H. van der en R. Hoppe (1989) Beleid en politiek: Een inleiding tot de beleidswetenschap en de beleidskunde, Muiderberg: Coutinho.

Gronden, J.W. van de en K.J.M. Mortelmans (2001) Mededinging en niet-economische belangen, Deventer: Kluwer.

Hanekamp, J.C. (2002) 'Het morele falen van het voorzorgsprincipe', Spil, 181-182.

Hazeu, C.A. (200oa) 'Sturingsmogelijkheden in het milieubeleid: Een institutioneeleconomisch perspectief', Milieu 15, 5: 241-252.

Hazeu, C.A. (20oob) Institutionele economie: Een optiek op organisatie- en sturingsvraagstukken, Bussum: Coutinho.

Hazeu, C.A. (2003) ‘Rio, Johannesburg, Waterloo?’, ESB, 88e jrg., 4, april 2003, nr. 4399, p.147.

Hazeu, C.A en I.J. Schoonenboom (2002) 'De lange weg naar een internationaal milieubeleid', blz. 189-205 in C.A. Hazeu en G.J. Kronjee (red.) De vitaliteit van de nationale staat in een internationaliserende wereld, Groningen: Stenfert Kroese.

Hazewinkel, F. (1997) 25jaar dcmr Milieudienst Rijnmond, Ridderkerk: Corns Broekzitter.

Held, D. (1996) Models of democracy, Cambridge: Polity Press.

Hemerijck, A.C. (2003) 'Vier kernvragen van beleid', Beleid en Maatschappij, Vol. 3o. No. 1, pp. 3-19

Henkens, P.L.C.M. en H. van Keulen (2001) 'Mineral policy in the Netherlands and nitrate policy within the European Community', Netherlands Journal of Agricultural Science, 49 e.v.

Henzen, I. (2001) De uitbreiding van de Europese Unie naar Midden-en Oost-Europa en het Europees milieubeleid. Oplossingsstrategieën ten aanzien van zowel de toetredingsproblematiek als de integratieproblematiek, Afstudeerscriptie Opleiding Europese Studies, Universiteit van Amsterdam.

Hisschemöller, M., P. Groenewegen, R. Hoppe en C.J.H. Midden (1998) Kennisbenutting en politieke keuze: Een dilemma voor het milieubeleid?, Werkdocument 65, Den Haag: Rathenau Instituut.

Hoogerwerf, A. en M. Herweijer (1998) Overheidsbeleid: Een inleiding in de beleidswetenschap, Alphen aan den Rijn: Samsom.

Interdepartementaal Beleidsonderzoek, Bedrijfsvoering RIVM, brief minister van vws, d.d. 30 mei 2001, Tweede Kamer, vergaderjaar 2000-2001, 27774, nrs. 1-2.

Intergovernmental Panel on Climate Change (2001) Summary for policymakers. A report of working group I of the Intergovernmental Panel on Climate Change en Summary for policymakers climate change 20o1: Mitigation, Genève.

Jasanoff, S. (1986) Risk management and political culture, New York: Russell Sage Foundation.

Jasanoff, S. (1990) The fifth branch: Science advisers as policymakers, Cambridge, Mass.: Harvard University Press.

Jasanoff, S. (1991) 'Acceptable evidence in a pluralistic society', blz. 29-47 in D.G. Mayo en 
R.D. Hollander (eds.) Acceptable evidence. Science and values in risk management, Oxford: Oxford University Press.

Kakebeeke, W. en K.E. Horvath (1999) ‘Het verdrag van Aarhus', Milieu en Recht 4: 98102.

Klijnstra, M. (2000) 'Het transparantiebeginsel toegepast op de openbaarheid in het milieurecht', Milieu en Recht 1: 3-8.

Knill, C. (2001) The Europeanisation of national administrations. Patterns of institutional change and persistence, Cambridge: Cambridge University Press.

Koning, M., E. Verkade en J. Hakfoort (2002) Gevolgen van uitbreiding Schiphol; Een kengetallen kosten-batenanalyse, Den Haag: Centraal Planbureau.

Lambers, C. (1994) De ontbrekende schakel in het milieurecht, Deventer: Kluwer.

Lambers, C. (2000) 'Het voorzorgsbeginsel', Milieu en Recht 7/8: 176-181.

Latour, B. (1999) Politiques de la nature. Comment faire entrer les sciences en démocratie, Parijs: La Découverte.

Leget, R. (2000) 'LTO gekant tegen Vogelrichtlijn', Tijdschrift oogst, 11 februari: 18-19.

Lucas, A. (2002) 'Het risicobegrip vanuit het perspectief van de financiële economie en kansrekening', blz. 25-66 in B. Wissink en J. Bouma (red.) Perspectieven op milieurisico's, WRR Werkdocumenten W128, Den Haag.

Majone, G. (2002) 'What price safety? The precautionary principle and its policy implications, JCMS 40, 1 .

March, J.G. (1994) A primer on decision making. How decisions happen, New York: The Free Press.

March, J.G. and J.P. Olsen (1995) Democratic governance, New York: The Free Press.

McIntyre, O. and Th. Mosedale (1992) 'The precautionary principle as norm of international customary law', Journal of Environmental Law 2: 221-241.

Met recht verantwoordelijk, Discussienota van de regering inzake de toekomst van de milieuwetgeving (2001), alsmede Verslag van een algemeen overleg d.d. 12 juli 2001, Tweede Kamer, vergaderjaar 200o-2001, 27664, nrs. 1, 2 en 3.

Michiels, F.C.M.A. (1992) De Wet milieubeheer, Zwolle: W.E.J. Tjeenk Willink.

Milliken, F.J. (1987) 'Three types of perceived uncertainty about the environment: State, effect, and response uncertainty', Academy of Management Review 12, 1: 133-134.

Ministerie van Landbouw, Natuurbeheer en Visserij (2002) Evaluatie Meststoffenwet, Brief aan de Tweede Kamer 15 november 2002 (www.minlnv.nl/infomart/parlemnt/2002/paro2358.htm).

Ministerie van Volkshuisvesting, Ruimtelijke Ordening en Milieubeheer (1989) Omgaan met risico's, Tweede Kamer, vergaderjaar 1988-1989, 21137, nr. 5.

Ministerie van Volkshuisvesting, Ruimtelijke Ordening en Milieubeheer (1999) Uitvoeringsnota klimaatbeleid, deel I (UNK I): Binnenlandse maatregelen, Den Haag.

Ministerie van Volkshuisvesting, Ruimtelijke Ordening en Milieubeheer (200o) Uitvoeringsnota klimaatbeleid, deel 2 (UNK II): Samenwerking met het buitenland, Den Haag.

Ministerie van Volkshuisvesting, Ruimtelijke Ordening en Milieu (2001a) Met recht verantwoordelijk! (discussienota), Den Haag: Ministerie van VROM.

Ministerie van Volkshuisvesting, Ruimtelijke Ordening en Milieubeheer (2001b) Strategienota Omgaan met stoffen, Tweede Kamer, vergaderjaar 2000-2001, 27646, nr. 2. 
Ministerie van Volkshuisvesting, Ruimtelijke Ordening en Milieubeheer (2002a) Vaste waarden, nieuwe vormen. Milieubeleid 2002-2006, Brief aan de Tweede Kamer.

Ministerie van Volkshuisvesting, Ruimtelijke Ordening en Milieubeheer (2002b) Evaluatienota klimaatbeleid. De voortgang van het Nederlandse klimaatbleid, Den Haag.

Nationaal Milieubeleidsplan I (1989) Tweede Kamer, vergaderjaar 1988-1989, 21137, nrs. 1-2.

Nationaal Milieubeleidsplan-plus (1990) Tweede Kamer, vergaderjaar 1989-1990, 21137, nr. 20.

Nationaal Milieubeleidspan II (1993) Tweede Kamer, vergaderjaar 1993-1994, 2356o, nrs. 1-2. Nationaal Milieubeleidsplan III (1998) Den Haag: ministerie van VROM.

Nationaal Milieubeleidsplan IV (2001) alsmede Verslag van een notaoverleg d.d. 5 november 2001, Tweede Kamer, vergaderjaar 2000-2001, 27801, nrs. 1, 2 en 13.

Olson, M. (1965) The logic of collective action (Public goods and the theory of groups), Cambridge Mass.: Harvard University Press.

Organisatie voor Economische Samenwerking en Ontwikkeling (2001) OECD Environmental Strategy for the first decade of the 21st century, Paris: oecd.

Ospar (1992) Oslo Paris Convention for the Protection of the Marine Environment of the North-East Atlantic (http://www.ospar.org/eng/html/welcome.html, download 14-06-02).

Peppel, R.A. van de (2002) 'De kwaliteit van milieuhandhaving', Beleidswetenschap 16 (3): 195-218.

Pieterman, R. (2001) 'Weg met het voorzorgsbeginsel', Nederlands Juristenblad, 1 juni.

Pieterman, R. and J.C. Hanekamp (2002) The cautious society? An essay on the rise of the precautionary culture, Amsterdam: Heidelberg Appeal Nederland.

Raad voor Ruimtelijk, Milieu- en Natuuronderzoek (2000) Andere sturing, andere kennis nodig?, Bijdrage jaarconferentie 200o, Utrecht/Rijswijk: RMNO.

Reijnders, L. (2002) 'Metingen op de pijnbank', Natuur en Milieu 26, 1/2: 28-29.

Rijksinstituut voor Volksgezondheid en Milieu (1988) Zorgen voor morgen, Alphen aan den Rijn: Samsom.

Rijksinstituut voor Volksgezondheid en Milieu (2000) Nationale milieuverkenning 5, 200o2030, Alphen aan den Rijn: Samsom.

Rijksinstituut voor Volksgezondheid en Milieu (2001a) Milieubalans 2001. Het Nederlandse milieu verklaard, Alphen aan den Rijn: Kluwer.

Rijksinstituut voor Volksgezondheid en Milieu (2001b) Uncertainty and rivm environmental outlooks, Documenting an learning process, Bilthoven: RIVM.

Rijksinstituut voor Volksgezondheid en Milieu (2002a) MINAS en milieu. Balans en verkenning, Rapport 718201005, Bilthoven: RIVM.

Rijksinstituut voor Volksgezondheid en Milieu (2002b) Milieubalans 2002. Het Nederlandse milieu verklaard, Alphen aan den Rijn: Kluwer.

Rosenthal, U., A.B. Ringeling, M.A.P. Bovens, P. 't Hart en M.J.W. van Twist (1996) Openbaar bestuur: Beleid, organisatie en politiek, Alphen aan den Rijn: Samsom/H.D. Tjeenk Willink.

Rozendaal, S. (1995) 'Chloor, het hulpje van de duivel?’, Elsevier, 29 april 1995.

Sbragia, A.M. (2000) 'Environmental policy', blz. 293-316 in Wallace and Wallace 2000.

Scharpf, F. (1999) Governing in Europe: Effective and democratic?, Oxford: Oxford University Press. 
Scharpf, F.W. (2002) The vitality of the nation state in 21th century Europe, Den Haag: WRR-lezing 18 december 2002.

Schwarz, M. and M. Thompson (1990) Divided we stand: Redefining politics, technology and social choice, New York: Harvester Wheatsheaf.

Sociaal-Economische Raad (2001) Advies nationaal milieubeleidsplan 4, Den Haag.

Sociaal Economische Raad (2003) Duurzaamheid vraagt om openheid - op weg naar een duurzame consumptie, Ontwerpadvies 14 februari 2003, Den Haag: SER.

Sievers, I. en L. Steg, 'Milieuproblemen als sociale dilemma's', Beleid en Maatschappij 1: 13-24.

Siraa, H.T., A.J. van der Valk en W.L. Wissink (1995) Een geschiedenis van de zorg voor de kwaliteit van de leefomgeving, het ministerie van VROM (1965-1995), Den Haag: Sdu Uitgevers.

Stuurgroep Chloor en Alternatieven (2001) Controverses rondom chloor - overbrugbaar? (http://www.vu.nl/ivm/envirofacts/stuchloa.pdf, download 17-10-2001).

Thornton, J. (2000) Pandora's poison: Chlorine, health, and a new environmental strategy, Cambridge: mit Press.

Tukker, A. (1999) Frames in the toxicity controversy: Risk assessment and policy analyses related to the Dutch chlorine debate and the Swedish pvc debate, Dordrecht: Kluwer Academic Publishers.

Vaubel, R. (2002) Europa-Chauvinismus. Der Hochmut der Institutionen, Munchen: Universitas Verlag.

Vereniging van de Nederlandse Chemische Industrie (1991) Integrated substance chain managemant, Den Haag: VNCI.

Verschuuren, J.M. (2000) De laatste wilde hamster in Nederland en de grondslagen van het Europese en internationale milieurecht, Deventer: Tjeenk Willink.

Visser, J. and A.C. Hemerijck (2001) Learning ahead of failure: A research agenda, Paper presented at the Max Planck Institute: Keulen.

VROM-raad (1999) Nederland en het Europese milieu, Den Haag.

VROM-raad (2001a) Tussen feit en fictie...,Verkenning van ontwikkelingen in de ICT en de gevolgen voor het beleid over wonen, ruimtelijke ordening, milieu en mobiliteit, Den Haag.

VROM-raad (2001b) Waar een wil is, is een weg, Advies over het NMP 4, Den Haag.

VROM-raad (2002) Milieu en economie:ontkoppeling door innovatie, Advies 036, Den Haag: vROM-raad.

Wallace H. and W. Wallace (eds.) (200o) Policy-making in the European Union, fourth edition, Oxford: Oxford University Press.

Weggeman, J. en M. de Jong (200o) 'Het groene poldermodel in perspectief', Beleidswetenschap 1: 72-96.

Weinberg, A.M. (1972) 'Science and trans-science', Minerva 10: 209-222.

Wetsontwerp op het RIVM (1995) Tweede Kamer, vergaderjaar 1995-1996, 24454.

Wet op het RIVM, Stb. 1996, 56o.

Wetenschappelijke Raad voor het Regeringsbeleid (1994a) Duurzame risico's: een blijvend gegeven, Rapporten aan de Regering nr. 44, Den Haag: Sdu Uitgevers.

Wetenschappelijke Raad voor het Regeringsbeleid (1994b) Besluiten over grote projecten, Rapporten aan de Regering nr. 46, Den Haag: Sdu Uitgevers.

Wetenschappelijke Raad voor het Regeringsbeleid (1999) Generatiebewust beleid, 
Rapporten aan de Regering nr. 55, Den Haag: Sdu Uitgevers.

Wetenschappelijke Raad voor het Regeringsbeleid (2001) Naar een Europabrede Unie, Rapporten aan de Regering nr. 59, Den Haag: Sdu Uitgevers.

Wetenschappelijke Raad voor het Regeringsbeleid (2002a) De toekomst van de nationale rechtsstaat, Rapporten aan de Regering nr. 63, Den Haag: Sdu Uitgevers.

Wetenschappelijke Raad voor het Regeringsbeleid (2002b) Duurzame ontwikkeling. Bestuurlijke voorwaarden voor een mobiliserend beleid, Rapporten aan de Regering nr. 62, Den Haag: Sdu Uitgevers.

Wetenschappelijke Raad voor het Regeringsbeleid (2002c) Van oude en nieuwe kennis. De gevolgen van ICT voor het kennisbeleid, Rapporten aan de Regering nr. 61, Den Haag: Sdu Uitgevers.

Wetenschappelijke Raad voor het Regeringsbeleid (2003a) Beslissen over biotechnologie, Rapporten aan de Regering nr. 64, Den Haag: Sdu Uitgevers.

Wetenschappelijke Raad voor het Regeringsbeleid (2003b) Milieubeleid in een veranderende context: zes voorbeelden, J. Burgers, F.J.P.M. Hoefnagel, F. den Hond (red.), Werkdocument 134, Den Haag.

Wetenschappelijke Raad voor het Regeringsbeleid (2003c) Slagvaardigheid in de Europabrede Unie, Rapporten aan de Regering nr. 65, Den Haag: Sdu Uitgevers.

Willems, W.J., Th.V. Vellinga, O. Oenema, J.J. Schroder en P.C. Struik (200o) Justification of the Dutch application for derogation of the European Nitrate Directive, Report nr. 718201002, Bilthoven: RIVM.

Wissink, B. (2001) 'Als meten geen weten kan zijn', Natuur en Milieu 25, 12: 28-29.

Wissink, B. en J. Bouma (red.) (2002) Perspectieven op milieurisico's, WRR Werkdocument 128, Den Haag: Sdu Uitgevers.

Wynne, B. (1992) 'Uncertainty and environmental learning: Reconceiving science and policy in the preventive paradigm', Global Environmental Change, June: 111-127.

Wynne, B. (2001) Managing scientific uncertainty in public policy, Harvard gmos background paper.

World Commission on Environment and Development (1987) Our common future, Oxford/New York: Oxford University Press.

Zouwen, M. van der en J.P.M. van Tatenhove (2002) Implementatie van Europees natuurbeleid in Nederland, Planbureaustudie nr. 1, Wageningen: Natuurplanbureau. 


\section{RAPPORTEN AAN DE REGERING}

Eerste raadsperiode (1972-1977)

Europese Unie*

2 Structuur van de Nederlandse economie*

3 Energiebeleid

Gebundeld in één publicatie (1974)*

4 Milieubeleid (1974)*

5 Bevolkingsgroei (1974)*

6 De organisatie van het openbaar bestuur (1975)*

7 Buitenlandse invloeden op Nederland: Internationale migratie (1976)*

8 Buitenlandse invloeden op Nederland: Beschikbaarheid van wetenschappelijke en technische kennis (1976)*

9 Commentaar op de Discussienota Sectorraden (1976)*

10 Commentaar op de nota Contouren van een toekomstig onderwijsbestel $(1976)^{*}$

11 Overzicht externe adviesorganen van de centrale overheid (1976)*

12 Externe adviesorganen van de centrale overheid (1976)*

13 Maken wij er werk van? Verkenningen omtrent de verhouding tussen actieven en niet-actieven (1977)*

14 Interne adviesorganen van de centrale overheid (1977)*

15 De komende vijfentwintig jaar - Een toekomstverkenning voor Nederland (1977)*

16 Over sociale ongelijkheid - Een beleidsgerichte probleemverkenning (1977)*

Tweede raadsperiode (1978-1982)

17 Etnische minderheden (1979)*

A. Rapport aan de Regering

B. Naar een algemeen etnisch minderhedenbeleid?

Plaats en toekomst van de Nederlandse industrie (1980)*

19 Beleidsgerichte toekomstverkenning

Deel 1: Een poging tot uitlokking (1980)*

Democratie en geweld. Probleemanalyse naar aanleiding van de gebeurtenissen in Amsterdam op 30 april 1980 *

Vernieuwingen in het arbeidsbestel (1981)*

Herwaardering van welzijnsbeleid (1982)*

Onder invloed van Duitsland. Een onderzoek naar gevoeligheid en kwetsbaarheid in de betrekkingen tussen Nederland en de Bondsrepubliek (1982)*

Samenhangend mediabeleid (1982)* 


\section{Derde raadsperiode (1983-1987)}

Beleidsgerichte toekomstverkenning

Deel 2: Een verruiming van perspectief $(1983)^{\star}$

Waarborgen voor zekerheid. Een nieuw stelsel van sociale zekerheid in hoofdlijnen (1985)

27 Basisvorming in het onderwijs (1986)

28 De onvoltooide Europese integratie (1986)

29 Ruimte voor groei. Kansen en bedreigingen voor de Nederlandse economie in de komende tien jaar (1987)

30 Op maat van het midden- en kleinbedrijf (1987)

Deel 1: Rapport aan de Regering;

Deel 2: Pre-adviezen

31 Cultuur zonder grenzen (1987)*

32 De financiering van de Europese Gemeenschap. Een interimrapport (1987)

33 Activerend arbeidsmarktbeleid (1987)

34 Overheid en toekomstonderzoek. Een inventarisatie (1988)

\section{Vierde raadsperiode (1988-1992)}

35 Rechtshandhaving (1988)

36 Allochtonenbeleid (1989)

37 Van de stad en de rand (1990)

38 Een werkend perspectief. Arbeidsparticipatie in de jaren '90 (1990)

39 Technologie en overheid (1990)

40 De onderwijsverzorging in de toekomst (1991)

41 Milieubeleid. Strategie, instrumenten en handhaafbaarheid (1992)

42 Grond voor keuzen. Vier perspectieven voor de landelijke gebieden in de Europese Gemeenschap (1992)

43 Ouderen voor ouderen. Demografische ontwikkelingen en beleid (1993)

\section{Vijfde raadsperiode (1993-1997)}

44 Duurzame risico's. Een blijvend gegeven (1994)

45 Belang en beleid. Naar een verantwoorde uitvoering van de werknemersverzekeringen (1994)

46 Besluiten over grote projecten (1994)

47 Hoger onderwijs in fasen (1995)

48 Stabiliteit en veiligheid in Europa. Het veranderende krachtenveld voor het buitenlands beleid (1995)

49 Orde in het binnenlands bestuur (1995)

50 Tweedeling in perspectief (1996)

51 Van verdelen naar verdienen. Afwegingen voor de sociale zekerheid in de 21e eeuw (1997)

52 Volksgezondheidszorg (1997)

53 Ruimtelijke-ontwikkelingspolitiek (1998)

54 Staat zonder land. Een verkenning van bestuurlijke gevolgen van informatie- en communicatietechnologie (1998) 


\section{Zesde raadsperiode (1998-2002)}

55 Generatiebewust beleid (1999)

56 Het borgen van publiek belang (2000)

57 Doorgroei van arbeidsparticipatie (2000)

58 Ontwikkelingsbeleid en goed bestuur (2001)

$59 \quad$ Naar een Europabrede Unie (2001)

60 Nederland als immigratiesamenleving (2001)

61 Van oude en nieuwe kennis. De gevolgen van ICT voor het kennisbeleid (2002)

62 Duurzame ontwikkeling: bestuurlijke voorwaarden voor een mobiliserend beleid (2002)

63 De toekomst van de nationale rechtsstaat (2002)

64 Beslissen over biotechnologie (2003)

65 Slagvaardigheid in de Europabrede Unie (2003)

66 Nederland handelsland. Het perspectief van de transactiekosten (2003)

Rapporten aan de Regering en publicaties in de reeks Voorstudies en achtergronden zijn verkrijgbaar in de boekhandel of via Sdu Servicecentrum Uitgeverijen, Plantijnstraat, Postbus 20014, 2500 EA 's-Gravenhage, tel. 070-3789880, fax 070-3789783. 


\title{
VOORSTUDIES EN ACHTERGRONDEN
}

\author{
Hieronder worden de publicaties uit de WRR-serie Voorstudies en achtergronden opgesomd vanaf de \\ vierde raadsperiode. Een volledig overzicht van de voorstudies is beschikbaar op de WRR-website \\ (http://www.wrr.nl) of aan te vragen bij het bureau van de WRR (070 - 3564625$)$.
}

\section{Vierde raadsperiode (1988-1992)}

Milieu en groei. Verslag van een studiedag op 11 februari 1988 (1988)

De maatschappelijke gevolgen van erfelijkheidsonderzoek. Verslag van een conferentie op 16-17 juni 1988 (1988)

H.F.L. Garretsen, H. Raat (1989) Gezondheid in de vier grote steden

P. de Grauwe e.a. ( 1989) De Europese Monetaire Integratie: vier visies

Th. Roelandt, J. Veenman (1990) Allochtonen van school naar werk

W.H. Leeuwenburgh, P. van den Eeden (1990) Onderwijs in de vier grote steden

M.W. de Jong, P.A. de Ruijter (red.) (1990) Logistiek, infrastructuur en de grote stad

C.A. Bartels, E.J.J. Roos (1990) Sociaal-economische vernieuwing in grootstedelijke gebieden

W.J. Dercksen (ed.) (1990) The Future of Industrial Relations in Europe. Proceedings of a conference in honour of prof. W. Albeda

Sociaal-economische gezondheidsverschillen en beleid; preadviezen (1991)

F.J.P.M. Hoefnagel (1992) Cultuurpolitiek: het mogen en moeten

K.W.H. van Beek, B.M.S. van Praag (1992) Kiezen uit sollicitanten. Concurrentie tussen werkzoekenden zonder baan Jeugd in ontwikkeling. Wetenschappelijke inzichten en overheidsbeleid (1992)

A.M.J. Kreukels, W.G.M. Salet (ed.) (1992) Debating institutions and Cities. Proceedings of the Anglo Dutch Conference on Urban Regeneration H.R. van Gunsteren en P. den Hoed (1992) Burgerschap in praktijken

F. Bletz, W. Dercksen and K. van Paridon (ed.) (1993) Shaping Factors for the Business Environment in the Netherlands after 1992

N.T. Bischoff, R.H.G. Jongman (1993) Development of Rural Areas in Europe. The Claim for Nature Verslag en evaluatie van de vierde raadsperiode (1993)

F.J.P.M. Hoefnagel m.m.v. H.G.M. Hendriks en M.D. Verdaasdonk (1993) Het Duitse Cultuurbeleid in Europa

\section{Vijfde raadsperiode (1993-1997)}

W.J. Dercksen e.a. (1993) Beroepswijs onderwijs. Ontwikkelingen en dilemma's in de aansluiting van onderwijs en arbeid W.G.M. Salet (1994) Om recht en staat. Een sociologische verkenning van sociale, politieke en rechtsbetrekkingen J.M. Bekkering (1994) Private verzekering van sociale risico's

C. Lambers, D.A. Lubach, M. Scheltema (1994) Versnelling juridische procedures grote projecten СSнов (1995) Aspecten van hoger onderwijs. Een internationale inventarisatie T. van der Meij e.a. (1995) Ontwikkelingen in de natuur. Visies op de levende natuur in de wereld en scenario's voor het behoud daarvan

L. Hagendoorn e.a. (1995) Etnische verhoudingen in Midden- en Oost-Europa H.C. Posthumus Meyjes, A. Szász, Christoph Bertram, W.F. van Eekelen (1995) Een gedifferentieerd Europa J. Rupnik e.a. (1995) Challenges in the East J.P.H. Donner (rapporteur) (1995) Europa, wat nu? R.M.A. Jansweijer (1996) Gouden bergen, diepe dalen: de inkomensgevolgen van een betaalbare oudedagsvoorziening W. Derksen, W.A.M. Salet (red.) (1996) Bouwen aan het binnenlands bestuur 
V95 L.J. Gunning-Schepers, G.J. Kronjee and R.A. Spasoff (eds.) (1996) Fundamental Questions about the Future of Health Care

V96 H.B.G. Ganzeboom en W.C. Ultee (red.) (1996) De sociale segmentatie van Nederland in 2015

V97 J.C.I. de Pree (1997) Grenzen aan verandering. De verhouding tussen reorganisatie en structuurprincipes van het binnenlands bestuur

V98 M.F. Gelok en W.M. de Jong (1997) Volatilisering in de economie

V99 A.H. Kleinknecht, R.H. Oostendorp, M.P. Pradhan (1997) Patronen en economische effecten van flexibiliteit in de Nederlandse arbeidsverhoudingen

V100 J.P.H. Donner (1998) Staat in beweging

V101 W.J. Vermeulen, J.F.M. van der Waal, H. Ernste, P. Glasbergen (1997) Duurzaamheid als uitdaging. De afweging van ecologische en maatschappelijke risico's in confrontatie en dialoog

V102 W. Zonneveld en A. Faludi (1998) Europese integratie en de Nederlandse ruimtelijke ordening

V103 Verslag en evaluatie van de vijfde raadsperiode (1998)

\section{Zesde raadsperiode (1998-2002)}

V104 Krijn van Beek (1998) De ondernemende samenleving. Een verkenning van maatschappelijke verandering en implicaties voor beleid

V105 W. Derksen et al. (1999) Over publieke en private verantwoordelijkheden

V106 Henk C. van Latesteijn (1999) Land use in Europe. A methodology for policy-oriented future studies

V107 Aart C. Liefbroer en Pearl A. Dykstra (2000) Levenslopen in verandering. Een studie naar ontwikkelingen in de levenslopen van Nederlanders geboren tussen 1900 en 1970

V108 Bart Wissink (2000) Ontworpen en ontstaan. Een praktijktheoretische analyse van het debat over het provinciale omgevingsbeleid

V109 H. Mommaas, m.m.v. W. Knulst en M. van den Heuvel (2000) De vrijetijdsindustrie in stad en land. Een studie naar de markt van belevenissen

V110 H. Dijstelbloem en C.J.M. Schuyt, red. (2002) De publieke dimensie van kennis

V111 M.C.E. van Dam-Mieras en W.M. de Jong, red. (2002) Onderwijs voor een kennissamenleving. De rol van ICT nader bekeken

V112 Wendy Asbeek Brusse, Harry van Dalen en Bart Wissink (2002) Stad en Land in een nieuwe geografie. Maatschappelijke veranderingen en ruimtelijke dynamiek

V113 G.A. van der Knaap (2002) Stedelijke bewegingsruimte. Over veranderingen in stad en land.

V114 F.J.P.M. Hoefnagel (2002) Internet en cultuurbeleid. Over de gevolgen van ICT voor het cultuurbeleid van de Nederlandse overheid

V115 Gabriël van den Brink (2002) Mondiger of moeilijker? Een studie naar de politieke habitus van hedendaagse burgers

V116 Willem Witteveen, Bart van Klink, met bijdragen van Wouter de Been en Peter Blok (2002) De sociale rechtsstaat voorbij. Twee ontwerpen voor het huis van de rechtsstaat

V117 Rein de Wilde, Nikki Vermeulen en Mirko Reithler (2003) Bezeten van genen. Een essay over de innovatieoorlog rondom genetisch gemodificeerd voedsel 


\section{Overige publicaties}

Voor de eenheid van beleid. Beschouwingen ter gelegenheid van vijftig jaar Ministerie van Algemene Zaken (1987)

Eigentijds burgerschap. WRR-publicatie onder leiding van H.R. van Gunsteren (1992)

Mosterd bij de maaltijd. 20/25 jaar WRR (1997)

De vitaliteit van de nationale staat in een internationaliserende wereld (2002) 
